\title{
“CONSTRUÇÃO DE MICROSSENSORES E SUA APLICAÇÃO PARA ESTUDO DE BIOFILME EMPREGADO NO TRATAMENTO DE
}

\section{ÁGUA RESIDUÁRIA"}

\author{
Dissertação apresentada à Escola de Engenharia de São \\ Carlos da Universidade de São Paulo, como parte dos requisitos \\ para obtenção do Título de Mestre em Engenharia Hidráulica e de \\ Saneamento.
}

Orientador: Prof. Titular José Roberto Campos 
FOLHA DE JULGAMENTO

Candidata: Licenciada BEATRIZ CRUZ GONZALEZ

Dissertação defendida e julgada em 22/05/2009 perante a Comissão Julgadora:

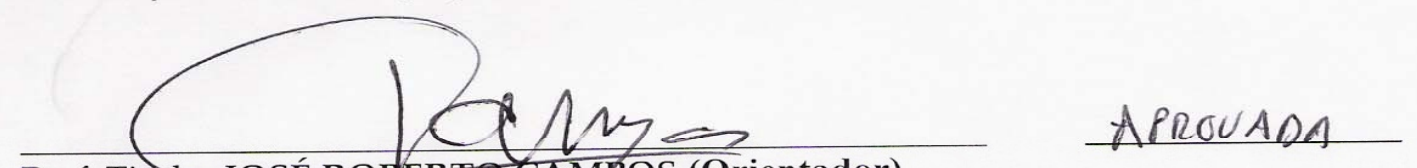

Prof. Titutar JOSÉ-ROPERTO CAMPOS (Orientador)

(Escola de Engenharia de São Carlds/USP)

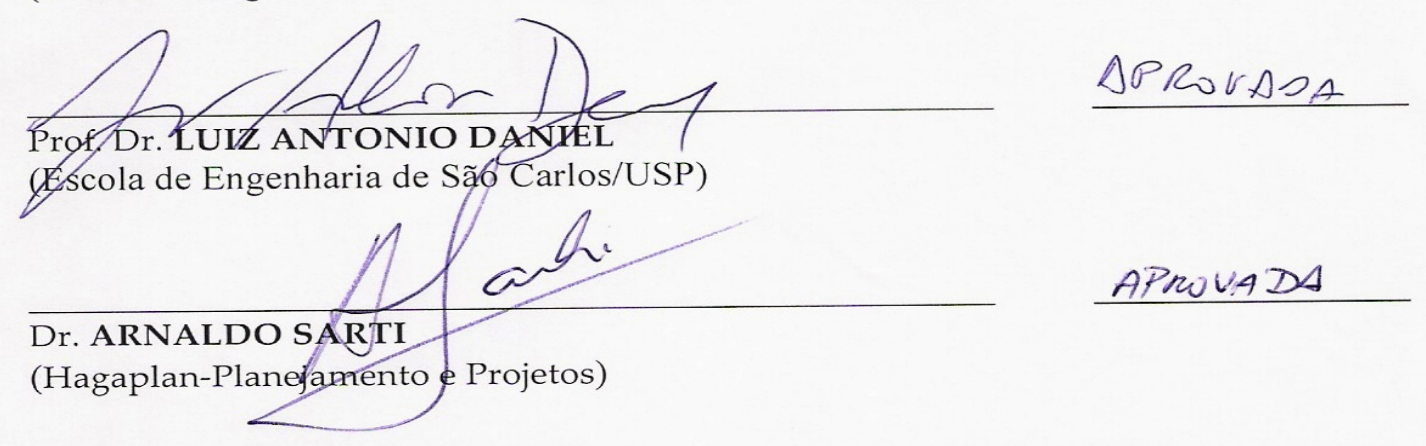

(Escola de Engenharia de São Carlos/USP)

APROVADA

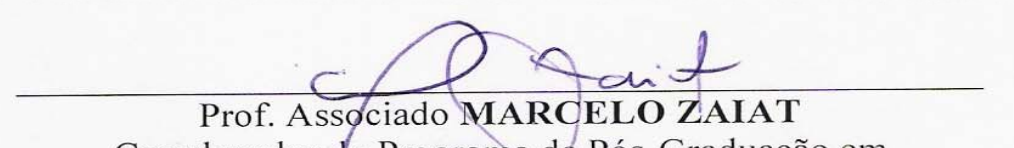

Coordenador do Programa de Pós-Graduação em

Engenharia (Hidráulica e Saneamento)

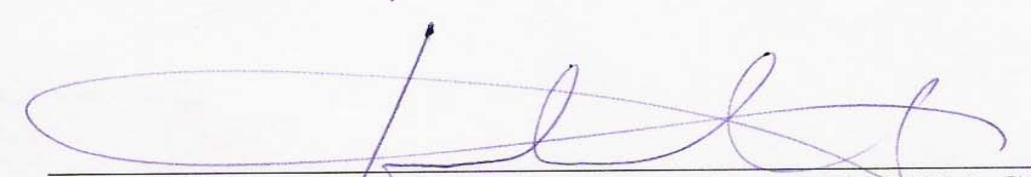

Prof. Associado GERALDO ROBERTO MARTINS DA COSTA Presidente da Comissão da Pós-Graduação da EESC 
Ao meu pai José Roberto Barros Gonzalez e à minha mãe Jocely Cruz Gonzalez, por todo amor, carinho e dedicação, sem os quais a realização dessa pesquisa não seria possível. 


\section{AGRADECIMENTOS}

Meus sinceros agradecimentos a todos que contribuíram de alguma forma para realização dessa pesquisa, em especial:

Ao professor José Roberto Campos, pela orientação e confiança durante o desenvolvimento do estudo em questão;

Ao Wagner não só pelo apoio, pela amizade e por tudo que me ensinou no Laboratório de Microssensores, mas acima de tudo pelo exemplo de pessoa que ele é: bondoso, alegre, solícito e afetuoso;

A CAPES pela concessão da bolsa e à FAPESP pelo auxílio financeiro;

A Aninha, pela companhia e coleguismo durante a execução desse trabalho e à Sabrina pelos microssensores construídos, pelas conversas agradáveis na hora do almoço e pela força concedida;

Ao professor Fatibello, do Departamento de Química da UFSCar pela ajuda nos assuntos concernentes à confecção dos sensores e ao Ademir (vidreiro da UFSCar) pelo apoio e pelas inúmeras tentativas relacionadas à manufatura dos vidros utilizados na construção dos microssensores;

Ao Doutor Arnaldo Sarti, pela ajuda na realização da parte experimental relacionada aos microssensores de $\mathrm{H}_{2} \mathrm{~S}$ e a Doutora Eloísa Pozzi, por te me acompanhado no decorrer da concretização do presente estudo;

À equipe do Laboratório de Saneamento, pela colaboração e ajuda nas análises físico-químicas; Aos funcionários do Departamento de Hidráulica e Saneamento, Sá, Pavi, Rose, Jaqueline, Fernanda e Flavinha. A Cirley pela benevolência e ternura; ao técnico Roberto Bérgamo pelo auxílio nos assuntos concernentes a elaboração de novos equipamentos;

Aos colegas do Departamento de Engenharia de Hidráulica e Saneamento Camila, Michele, Tiago, Vitor, Tiagão, Walter, César, Aníbal, Nayara e Jaqueline;

Aos meus amigos de Santos, Thalita, Débora, Tutu, Lopes, Fabinho, Si, Ju, Robinho e Zoba, pela lealdade e pelos inúmeros encontros agradabilíssimos e divertidos;

Aos meus irmãos e irmãs (muito queridos) de São Carlos, Juba, Iná, Si, Má, Indira, Alê, Fê (24), Harry, Allan, Bruno e Fê (Avaré), pela amizade sincera, pelas muitas risadas e pelos incontáveis e inesquecíveis bons momentos que passamos juntos;

À minha família que eu tanto amo, Pai, Mãe, Carol, Léo e Má e Yami, pelo apoio e amor incondicional, por todos os momentos maravilhosos e felizes, e por terem estado sempre ao meu lado me 
encorajando durante o extenso e difícil caminho percorrido ao longo do desenvolvimento da presente pesquisa. Devo tudo a eles;

Ao meu namorado Benedicto Augusto (ou Neguinho...) pelo amor, pela atenção, compreensão e ajuda concedida em inúmeros sentidos. Seu amor tornou tudo mais leve e belo e seu companheirismo me fez sentir completa e acima de tudo, feliz.

E por fim, a Deus por ter iluminado meu caminho e por ter estado sempre presente em minha vida. 
"Para realizar grandes conquistas, devemos não apenas agir, mas também sonhar; não apenas planejar, mas também acreditar".

Anatole France 


\section{RESUMO}

Gonzalez, B. C. (2009) Construção de microssensores e sua aplicação para estudo de biofilme empregado no tratamento de água residuária. Dissertação (Mestrado) - Escola de Engenharia de São Carlos, Universidade de São Paulo. São Carlos, 2009.

A presente pesquisa teve como objetivo a construção de microssensores amperométricos e potenciométricos para mensuração de oxigênio dissolvido $(\mathrm{OD})$, gás sulfídrico $\left(\mathrm{H}_{2} \mathrm{~S}\right)$, íons amônio $\left(\mathrm{NH}_{4}{ }^{+}\right)$, nitrato $\left(\mathrm{NO}_{3}{ }^{-}\right)$, nitrito $\left(\mathrm{NO}_{2}{ }^{-}\right)$e hidrogeniônicos $\left(\mathrm{H}^{+}\right)$em biofilmes aplicados a nitrificação de água residuária. Os biofilmes analisados por meio do uso dos microssensores construídos foram desenvolvidos sobre superfícies suportes de reatores de bancada do tipo "célula de fluxo", as quais foram operadas sob diferentes condições operacionais em cinco experimentos distintos. Substrato sintético com concentrações de nitrogênio total Kjeldahl (NTK) de $40 \pm 10 \mathrm{mg}$. $\mathrm{L}^{-1}$ e demanda química de oxigênio (DQO) de $95 \pm 5 \mathrm{mg} . \mathrm{L}^{-1}$ foi utilizado para alimentação das células de fluxo no decorrer de todos os experimentos. Lodo aeróbio proveniente de Reator de Lodos Ativados da Estação de Tratamento de Esgoto das Flores localizada em Rio Claro- SP foi usado como inóculo das células de fluxo. Análises físico-químicas de $\mathrm{pH}$, alcalinidade, $\mathrm{DQO}, \mathrm{NTK}, \mathrm{NO}_{3}{ }^{-}, \mathrm{NO}_{2}{ }^{-}$do afluente e do efluente das células de fluxo operadas foram realizadas para o monitoramento das condições de operação das mesmas. Concomitantemente às últimas, a obtenção de perfis de concentrações de oxigênio dissolvido, $\mathrm{pH}$, íons nitrato e amônio foi realizada nos biofilmes formados sobre as superfícies inertes nas células. Os microssensores de OD se mostraram eficientes na mensuração de oxigênio dissolvido no interior de filmes biológicos que continham zonas aeróbias, anóxicas e anaeróbias. Os microeletrodos de $\mathrm{pH}$ e de íons amônio permitiram a verificação das variações de $\mathrm{pH}$ e das concentrações de $\mathrm{NH}_{4}{ }^{+}$(sentido meio líquido- biofilme) que se deram nas células de fluxo operadas. Os microssensores de íons nitrato construídos não apresentaram seletividade aos seus analitos $\left(\mathrm{NO}_{3}{ }^{-}\right)$e foi constatado que os mesmos detectavam concentrações de íons nitrato e nitrito no meio, portanto esses passaram a ser denominados de microssensores para detecção de íons $\mathrm{NO}_{\mathrm{x}}^{-}$. A construção dos microeletrodos destinados a mensuração de íons nitrito não foi passível de realização visto que a membrana íon seletiva que seria aplicada nos mesmos não se encontrou disponível no mercado. Os microeletrodos de $\mathrm{H}_{2} \mathrm{~S}$ foram calibrados e, mediante as suas curvas de calibração verificou-se que os mesmos foram eficientes na medição da concentração do gás dissolvido em água, entretanto esses microssensores não foram empregados em biofilmes.

Palavras-Chaves: Microssensores, biofilmes, célula de fluxo, tratamento de água residuária. 


\begin{abstract}
Gonzalez, B. C. (2009) Construction of microsensors and its application in biofilms used in wastewater treatment. Dissertation - Escola de Engenharia de São Carlos, Universidade de São Paulo. São Carlos, 2009.

The goal of the current research was the construction of amperometric and potentiometric microsensors to measure dissolved oxygen (DO), hydrogen sulfide $\left(\mathrm{H}_{2} \mathrm{~S}\right)$, nitrite, nitrate, ammonium and $\mathrm{pH}$ in biofilms applied at wastewater treatment. The biofilms that were analyzed with the constructed microsensors were grown at the surface of flat-plate reactors, which were operated in five distinct experiments under different operational conditions. The growth media that had total Kjeldahl nitrogen (TNK) of $40 \pm 10 \mathrm{mg} / \mathrm{L}$ and carbon oxygen demand (COD) of $90 \pm 5 \mathrm{mg} / \mathrm{L}$ was used as feed of the flatplate reactors during the experiments. The reactors were inoculated with sludge originating from activated sludge reactor located in Rio Claro (SP). Alkalinity, $\mathrm{pH}, \mathrm{COD}, \mathrm{NO}_{3}{ }^{-}, \mathrm{NO}_{2}{ }^{-}$analyses of the affluent and effluent of the reactors were carried out for the accompaniment of the operational conditions of the flat-plate reactors. Concomitantly to the last ones, microprofiles of $\mathrm{DO}$, $\mathrm{pH}$, nitrate and ammonium were obtained in the biofilms. The DO microsensors constructed showed a good performance when they were applied to measure oxygen concentrations in the microenvironments in biofilms. Ammonium and $\mathrm{pH}$ microelectrodes allowed the verification of the variations of $\mathrm{pH}$ and ammonium concentrations in the direction from the bulk liquid to the biofilm that occurred at the flatplate reactors. The nitrate microsensor has not presented selectivity for its primary ions $\left(\mathrm{NO}_{3}{ }^{-}\right)$and it was evidenced that the same one detected the concentration of nitrate and nitrite $\left(\mathrm{NO}_{\mathrm{x}}{ }^{-}\right)$. The nitrite microsensor could not be constructed since the membrane that would be used was not available in the market. The $\mathrm{H}_{2} \mathrm{~S}$ microelectrodes had shown efficiency in measuring aqueous solutions with different concentrations of dissolved $\mathrm{H}_{2} \mathrm{~S}$; however these devices were not applied in biofilms.
\end{abstract}

Key words: Microsensors, biofilms, flat-plate reactors, wastewater treatment. 


\section{ÍNDICE DE FIGURAS}

Figura 3. 1: Métodos eletroanalíticos: sua classificação geral (Fonte: SKOOG; HOLLER; NIEMAN,

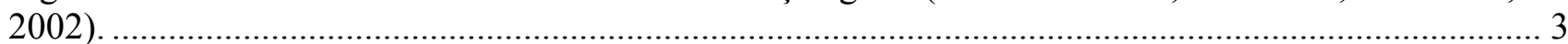

Figura 3. 2: Ilustração de célula eletroquímica (Fonte: BETTIN; TEIXEIRA; SANTOS, 2006)............ 4

Figura 3. 3: Cronologia do desenvolvimento da potenciometria (Fonte: KUBOTA; FERNANDES;

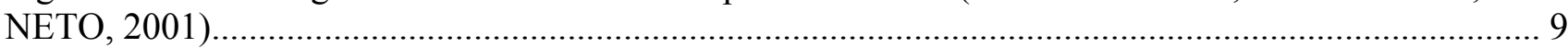

Figura 3. 4: Fórmulas estruturais de ionóforos cátion - seletivos (Fonte: BAKKER; BUHLMANN;

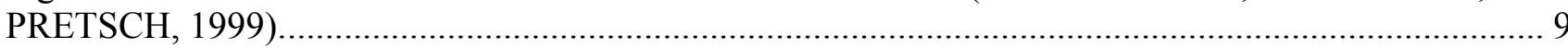

Figura 3. 5: Camadas de transporte do oxigênio até a superfície do catodo (Fonte: Adaptado de FERREIRA, 2007).

Figura 3. 6: Ilustrações dos microssensores de pH: (a) membrana de troca íon líquida, (b) membrana de vidro íon sensitiva e (c) de metais em sua forma oxidada. (Fonte: Modificada de LEWANDOWSKI; BEYENAL, 2003).

Figura 3. 7: Esquema ilustrativo das reações ocorridas na detecção amperométrica de $\mathrm{H}_{2} \mathrm{~S}$ (Fonte:

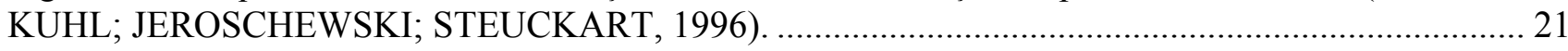

Figura 3. 8: Ilustração do desenvolvimento do biofilme (Fonte: Adaptado de STOODLEY; DIRKX,

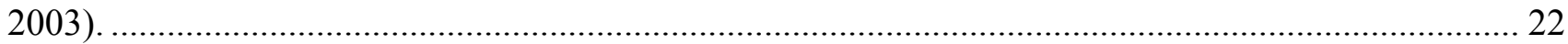

Figura 3. 9: Ilustração de biofilme com zonas distintas (Fonte: Adaptado de NEDOVIC et al., 2005). 23

Figura 3. 10: Esquema de biofilme em que ocorre nitrificação e penetração total de $\mathrm{NH}_{3}$, matéria orgânica e OD (esquerda). Esquema de biofilme no qual ocorre penetração total de $\mathrm{NH}_{3}$ e parcial de $\mathrm{OD}$ e matéria orgânica (direita) (Fonte: Adaptado de CAMPOS, 1989).

Figura 3. 11: Modelo da arquitetura de um biofilme heterogêneo (Fonte: COSTERSTON et al., 1995).

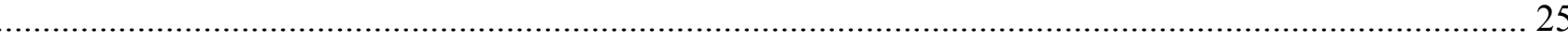

Figura 3. 12: Ilustração dos locais de introdução do microssensor em biofilme e seus respectivos perfis de [OD] (Fonte: LEWANDOWSKI et al., 1995).

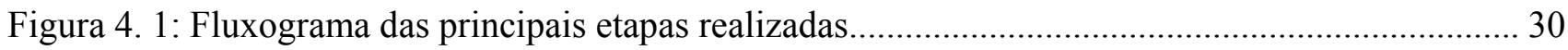

Figura 4. 2: Fotografia microscópica (aumento de $100 \mathrm{X}$ ) do microssensor de OD. ........................... 32

Figura 4. 3: Ilustração esquemática da região próxima a ponta de microssensor de $\mathrm{H}_{2} \mathrm{~S}$ (Fonte:

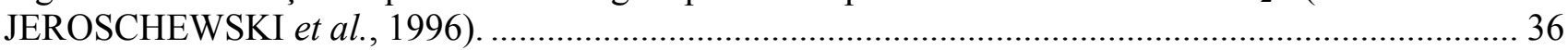

Figura 4. 4: Fotografia do microssensor de $\mathrm{H}_{2} \mathrm{~S}$ antes e depois de colorido de preto. ......................... 36

Figura 4. 5: Fotografia do aparato experimental utilizado para obtenção de solução concentrada de $\mathrm{H}_{2} \mathrm{~S}$.

Figura 4. 6: Fotografia da evolução da degradação do eletrodo de $\mathrm{Ag} / \mathrm{AgCl}$ em microssensores de OD.

Figura 4. 7: Fotografia dos suportes adaptados para o armazenamento de microssensores e de seus

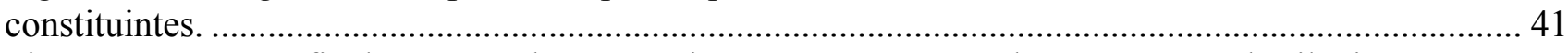

Figura 4. 8: Fotografia do suporte de compartimentos externos usado no processo de silanização........ 41

Figura 4. 9: Fotografia do suporte criado para clorinização dos fios de prata...................................... 42

Figura 4. 10: Fotografia do capilar de vidro repleto de pequenas bolhas............................................. 43

Figura 4. 11: Fotografia do catodo do microssensor de OD com "pêlo de vidro" em sua ponta........... 43

Figura 4. 12: Fotografia do catodo do microssensor de OD com vão entre o vidro e o fio de platina.... 44

Figura 4. 13: Fotografia do eletrodo de trabalho (do microssensor de OD) ideal. ................................ 44

Figura 4. 14- Ilustração do reator tipo "célula de fluxo" (medidas em $\mathrm{cm}$ ). ......................................... 45

Figura 4. 15- Fotografia do reator tipo "célula de fluxo". .................................................................... 45 
Figura 4. 16: Ilustração do Sistema completo. 1-Picoamperímetro; 2-Computador; 3-driver do servomotor; 4-compressor de ar (Big Air $^{\circledR}$-A420); 5- microscópio invertido (Olympus ${ }^{\circledR}$-IX51) integrado com câmera digital (Samsung ${ }^{\circledR}$-SDC-313); 6-célula de fluxo; 7-microssensor; 8-servo-motor e micromanipulador; 9-bomba peristáltica; 10-substrato sintético; 11 -bomba peristáltica...................... 48 Figura 4. 17: Fotografia das três células de fluxo em operação no experimento A................................ 50

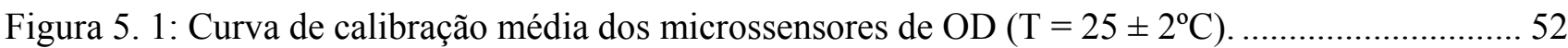
Figura 5. 2: Comportamento típico dos microssensores de $\mathrm{OD}$ durante a calibração $\left(\mathrm{T}=25 \pm 2^{\circ} \mathrm{C}\right) \ldots . .53$ Figura 5. 3: (A) Curvas de calibração de dez microssensores de $\mathrm{pH}$ e curva média das mesmas $\left(\mathrm{R}^{2}=0,9966\right) \quad\left(\mathrm{T}=25 \pm 2^{\circ} \mathrm{C}\right)$. (B) Curva de calibração teórica de um microssensor de $\mathrm{pH}\left(\mathrm{R}^{2}=1\right)$ (Fonte: LEWANDOWSKI; BEYENAL, 2006).

Figura 5. 4: Curvas de calibração com desvios de potencial de dez microssensores de $\mathrm{pH}$ e curva média

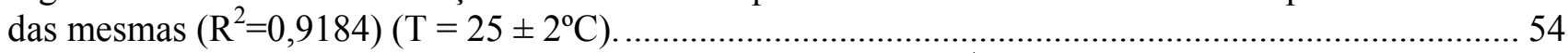
Figura 5. 5: Curvas de calibração de dez microssensores de $\mathrm{NH}_{4}{ }^{+}$...................................................... 55 Figura 5. 6: Curvas de calibração com desvios de potencial de dez microssensores de $\mathrm{NH}_{4}{ }^{+}$e curva

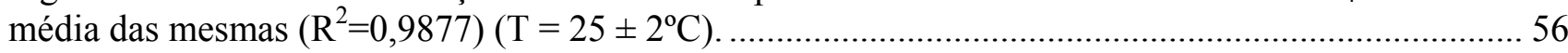

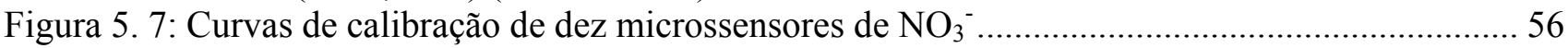
Figura 5. 8: Curvas de calibração com desvios de pontecial de dez microssensores de $\mathrm{NO}_{3}{ }^{-}$e curva

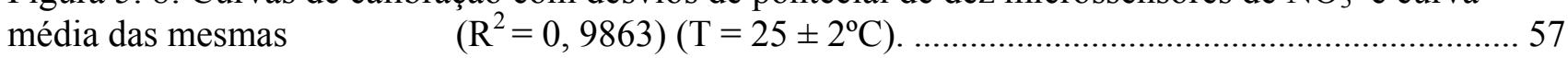
Figura 5. 9: Curvas de calibração obtidas mediante uso de dois microssensores de $\mathrm{H}_{2} \mathrm{~S}\left(\mathrm{~T}=25 \pm 2^{\circ} \mathrm{C}\right)$.

Figura 5. 10: Curva de calibração teórica de microssensores de $\mathrm{H}_{2} \mathrm{~S}$ (Fonte: JEROSCHEWSKI et al.,1996).

Figura 5. 11: Microssensores de $\mathrm{H}_{2} \mathrm{~S}$ construído e aplicado (esquerda) e do microssensor de $\mathrm{H}_{2} \mathrm{~S}$ ideal (direita).

Figura 5. 12: Gráficos das concentrações de OD obtidos nos testes dos dois tipos de eletrodos de $\mathrm{Ag} / \mathrm{AgCl}$ em função de tempo $\left(\mathrm{T}=25 \pm 2^{\circ} \mathrm{C}\right)$.

Figura 5. 13: Gráfico do teste de seletividade dos microssensores de íons nitrato $\left(\mathrm{T}=25 \pm 2^{\circ} \mathrm{C}\right)$........ 63

Figura 5. 14: Microperfis de [OD] obtidos nos $1^{\circ}, 2^{\circ}, 3^{\circ}$ e $4^{\circ}$ dias do experimento

(Taxa $_{\text {carreg. }}=1,5 \mathrm{~g} \mathrm{~N} / \mathrm{m}^{2}{ }_{\text {biofilme.dia, Vel. }}$ superficial $\left.=1 \mathrm{~m} / \mathrm{h}, \mathrm{T}=25 \pm 2^{\circ} \mathrm{C}\right)$....

Figura 5. 15: Representação da variação das espessuras em biofilmes verificadas através do uso de microssensores de OD (Fonte: Adaptado de DE BEER et al., 1993).

Figura 5. 16: Micrografias (aumento de $100 \mathrm{X}$ ) dos biofilmes no $1^{\circ}, 2^{\circ}$ (fotos superiores), $3^{\circ}$ e $4^{\circ}$ (fotos inferiores) dias do experimento (Taxa ${ }_{\text {carreg. }}=1,5 \mathrm{~g} \mathrm{~N} / \mathrm{m}^{2}$ biofilme.dia, Vel. superficial $=1 \mathrm{~m} / \mathrm{h}$ ).............. 67 Figura 5. 17: Perfis de concentração de OD no $5^{\circ}$ dia do experimento (Taxa carreg. $=1,5 \mathrm{~g} \mathrm{~N} / \mathrm{m}^{2}{ }_{\text {biofilme.dia, }}$,

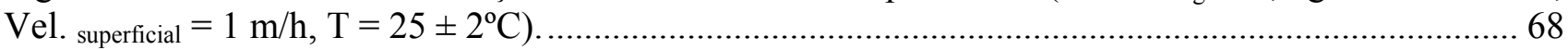
Figura 5. 18: Microperfis de [OD] $(\mathrm{mg} / \mathrm{L})$ obtidos nos dois últimos dias do experimento (Taxa carreg. $=1,5 \mathrm{~g} \mathrm{~N} / \mathrm{m}^{2}$ biofilme.dia, Vel. superficial $=1 \mathrm{~m} / \mathrm{h}, \mathrm{T}=25 \pm 2{ }^{\circ} \mathrm{C}$ ).

Figura 5. 19: Micrografia (aumento de $200 \mathrm{X}$ ) do biofilme no último dia do experimento

(Taxa carreg. $=1,5 \mathrm{~g} \mathrm{~N} / \mathrm{m}^{2}$ biofilme.dia, Vel. superficial $=1 \mathrm{~m} / \mathrm{h}$ ).

Figura 5. 20:Perfis de OD dos biofilmes dos quatro primeiros dias de operação da célula de fluxo

(Taxa carreg. $=0,5 \mathrm{~g} \mathrm{~N} / \mathrm{m}^{2}$ biofilme. dia, Vel. superficial $=8 \mathrm{~m} / \mathrm{h}, \mathrm{T}=25 \pm 2^{\circ} \mathrm{C}$ )......................................... 72

Figura 5. 21: Micrografias (aumento de $100 \mathrm{X}$ ) dos biofilmes no $1^{\circ}$ e $3^{\circ}$ dias do experimento, na devida

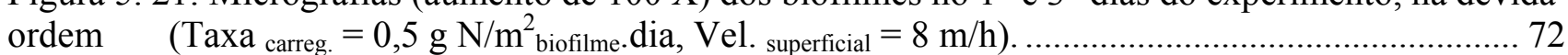
Figura 5. 22: Micrografias (aumento de $100 \mathrm{X}$ ) dos biofilmes no $5^{\circ}, 7^{\circ}$ e $9^{\circ}$ dias do experimento (Taxa carreg. $=0,5 \mathrm{~g} \mathrm{~N} / \mathrm{m}^{2}$ biofilme.dia, Vel. superficial $=8 \mathrm{~m} / \mathrm{h}$ ). 
Figura 5. 23: Perfis de concentração de OD no interior dos biofilmes desenvolvidos nos dias restantes do experimento (Taxa carreg. $=0,5 \mathrm{~g} \mathrm{~N} / \mathrm{m}_{\text {biofilme.dia, Vel. superficial }}^{2}=8 \mathrm{~m} / \mathrm{h}, \mathrm{T}=25 \pm 2^{\circ} \mathrm{C}$ ).

Figura 5. 24: Valores de $\mathrm{pH}$ do afluente e efluente da célula de fluxo ao longo do experimento

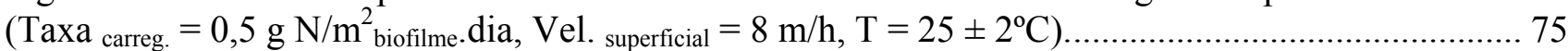

Figura 5. 25: Valores de alcalinidade no afluente e efluente da célula de fluxo .................................. 75

Figura 5. 26: Concentrações de íons nitrito $\left(\mathrm{NO}_{2}{ }^{-}\right)$e nitrato $\left(\mathrm{NO}_{3}{ }^{-}\right)$no efluente do sistema durante

a operação (Taxa carreg. $=0,5 \mathrm{~g} \mathrm{~N} / \mathrm{m}^{2}$ biofilme.dia, Vel. superficial $\left.=8 \mathrm{~m} / \mathrm{h}, \mathrm{T}=25 \pm 2^{\circ} \mathrm{C}\right) \ldots \ldots \ldots \ldots \ldots \ldots \ldots \ldots \ldots . . . . \ldots \ldots$

Figura 5. 27: Perfis de OD e de pH obtidos no $1^{\circ}$ dia de operação das células de fluxo $1 ; 2$ e 3.

Taxa ${ }_{\text {carreg. }}=0,5 \mathrm{~g} \mathrm{~N} / \mathrm{m}^{2}{ }_{\text {biofilme.dia, Vel. superficial }}=1 \mathrm{~m} / \mathrm{h}$ (cél 1), $8 \mathrm{~m} / \mathrm{h}$ (cél 2) e $4 \mathrm{~m} / \mathrm{h}$ (cél 3), $\mathrm{T}=25 \pm$

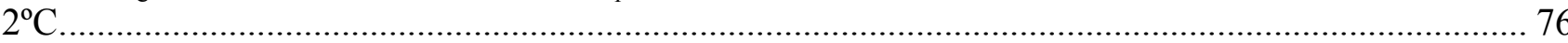

Figura 5. 28: Perfis de OD obtidos no $3^{\circ}$ dia de operação das células de fluxo $1 ; 2$ e 3.

Taxa ${ }_{\text {carreg. }}=0,5 \mathrm{~g} \mathrm{~N} / \mathrm{m}^{2}{ }_{\text {biofilme.dia, Vel. } \text { superficial }}=1 \mathrm{~m} / \mathrm{h}$ (cél 1), $8 \mathrm{~m} / \mathrm{h}$ (cél 2) e $4 \mathrm{~m} / \mathrm{h}$ (cél 3), $\mathrm{T}=25 \pm$

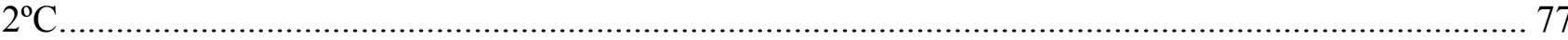

Figura 5. 29: Perfis de OD obtidos no $6^{\circ}$ dia de operação das células de fluxo $1 ; 2$ e 3.

Taxa ${ }_{\text {carreg. }}=0,5 \mathrm{~g} \mathrm{~N} / \mathrm{m}^{2}{ }_{\text {biofilme.dia, Vel. superficial }}=1 \mathrm{~m} / \mathrm{h}$ (cél 1), $8 \mathrm{~m} / \mathrm{h}$ (cél 2) e $4 \mathrm{~m} / \mathrm{h}$ (cél 3), $\mathrm{T}=25 \pm$

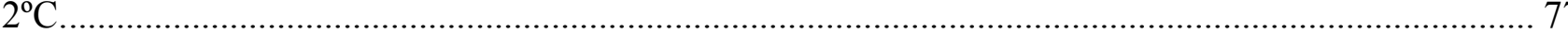

Figura 5. 30: Perfis de $\mathrm{NO}_{3}{ }^{-}$obtidos no $8^{\circ}$ dia de operação das células de fluxo $1 ; 2$ e 3.

Taxa ${ }_{\text {carreg. }}=0,5 \mathrm{~g} \mathrm{~N} / \mathrm{m}^{2}$ biofilme.dia, Vel. superficial $=1 \mathrm{~m} / \mathrm{h}$ (cél 1), $8 \mathrm{~m} / \mathrm{h}$ (cél 2) e $4 \mathrm{~m} / \mathrm{h}$ (cél 3), $\mathrm{T}=25 \pm$ $2^{\circ} \mathrm{C}$

Figura 5. 31: Alcalinidade do afluente e dos efluentes das três células de fluxo (1; 2 e 3$)$.

Taxa carreg. $=0,5 \mathrm{gN} / \mathrm{m}^{2}{ }_{\text {bifilme.dia, Vel. superficial }}=1 \mathrm{~m} / \mathrm{h}$ (cél 1), $8 \mathrm{~m} / \mathrm{h}$ (cél 2) e $4 \mathrm{~m} / \mathrm{h}$ (cél 3), $\mathrm{T}=25 \pm$ $2^{\circ} \mathrm{C}$

Figura 5. 32: Valores de $\mathrm{pH}$ no afluente e nos efluentes das três células de fluxo.

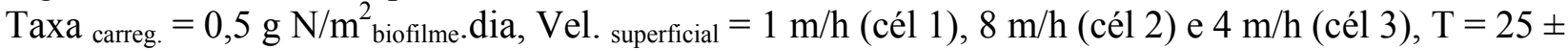
$2^{\circ} \mathrm{C}$

Figura 5. 33: Concentrações de NTK no afluente e nos efluentes das três células de fluxo (esquerda).

Consumo de NTK (\%) nas três células de fluxo (direita). Taxa carreg. $=0,5 \mathrm{~g} \mathrm{~N} / \mathrm{m}^{2}$ biofilme.dia, Vel. superficial

$=1 \mathrm{~m} / \mathrm{h}$ (cél 1), $8 \mathrm{~m} / \mathrm{h}$ (cél 2) e $4 \mathrm{~m} / \mathrm{h}$ (cél 3), $\mathrm{T}=25 \pm 2^{\circ} \mathrm{C}$.

Figura 5. 34: Concentrações dos íons $\mathrm{NO}_{2}{ }^{-}$e $\mathrm{NO}_{3}{ }^{-}$nos efluentes das três células de fluxo $(1 ; 2 \mathrm{e} 3)$.

Taxa ${ }_{\text {carreg. }}=0,5 \mathrm{~g} \mathrm{~N} / \mathrm{m}^{2}{ }_{\text {biofilme.dia, Vel. } \text { superficial }}=1 \mathrm{~m} / \mathrm{h}$ (cél 1), $8 \mathrm{~m} / \mathrm{h}$ (cél 2) e $4 \mathrm{~m} / \mathrm{h}$ (cél 3), $\mathrm{T}=25 \pm$ $2^{\circ} \mathrm{C}$

Figura 5. 35: Microperfis de oxigênio dissolvido nos biofilmes das três células de fluxo $1^{\circ}$ dia de operação Taxa carreg. $=1,0 \mathrm{~g} \mathrm{~N} / \mathrm{m}^{2}{ }_{\text {biofilme.dia, Vel. superficial }}=1 \mathrm{~m} / \mathrm{h}$ (cél 1), $8 \mathrm{~m} / \mathrm{h}$ (cél 2) e $4 \mathrm{~m} / \mathrm{h}$ (cél 3), T $=25 \pm 2^{\circ} \mathrm{C}$.

Figura 5. 36: Microperfis de íons $\mathrm{NO}_{\mathrm{x}}{ }^{-}$, de íons amônio $\left(\mathrm{NH}_{4}{ }^{+}\right)$e de $\mathrm{pH}$ nos biofilmes das três células de fluxo no $2^{\circ}$ dia do experimento. Taxa carreg. $=1,0 \mathrm{~g} \mathrm{~N} / \mathrm{m}^{2}$ biofilme.dia, Vel. superficial $=1 \mathrm{~m} / \mathrm{h}$ (cél 1), $8 \mathrm{~m} / \mathrm{h}$ (cél 2) e $4 \mathrm{~m} / \mathrm{h}$ (cél 3), $\mathrm{T}=25 \pm 2^{\circ} \mathrm{C}$.

Figura 5. 37: Microperfis de OD e de $\mathrm{pH}$ nos biofilmes das três células de fluxo no $5^{\circ}$ dia do experimento. Taxa carreg. $=1,0 \mathrm{~g} \mathrm{~N} / \mathrm{m}^{2}$ biofilme.dia, Vel. superficial $=1 \mathrm{~m} / \mathrm{h}$ (cél 1), $8 \mathrm{~m} / \mathrm{h}$ (cél 2) e $4 \mathrm{~m} / \mathrm{h}$ (cél 3), $\mathrm{T}=25 \pm 2^{\circ} \mathrm{C}$.

Figura 5. 38: Microperfis de íons nitrato, íons amônio e de OD nos biofilmes das três células de fluxo no $7^{\circ}$ dia do experimento. Taxa carreg. $=1,0 \mathrm{~g} \mathrm{~N} / \mathrm{m}^{2}$ biofilme. dia, Vel. superficial $=1 \mathrm{~m} / \mathrm{h}$ (cél 1), $8 \mathrm{~m} / \mathrm{h}$ (cél 2) e $4 \mathrm{~m} / \mathrm{h}$ (cél 3), $\mathrm{T}=25 \pm 2^{\circ} \mathrm{C}$.

Figura 5. 39: Microperfis de OD no $8^{\circ}$ dia do experimento nos biofilmes das três células de fluxo.

Taxa carreg. $=1,0 \mathrm{~g} \mathrm{~N} / \mathrm{m}^{2}{ }_{\text {biofilme.dia, Vel. superficial }}=1 \mathrm{~m} / \mathrm{h}$ (cél 1), $8 \mathrm{~m} / \mathrm{h}$ (cél 2) e $4 \mathrm{~m} / \mathrm{h}$ (cél 3), $\mathrm{T}=25 \pm$ $2^{\circ} \mathrm{C}$ 
Figura 5. 40: Valores das concentrações de íons amônio determinadas por microssensores no $7^{\circ}$ dia do experimento. Taxa ${ }_{\text {carreg. }}=1,0 \mathrm{~g} \mathrm{~N} / \mathrm{m}^{2}$ biofilme.dia, Vel. superficial $=1 \mathrm{~m} / \mathrm{h}$ (cél 1), $8 \mathrm{~m} / \mathrm{h}$ (cél 2) e $4 \mathrm{~m} / \mathrm{h}$ (cél $3), \mathrm{T}=25 \pm 2^{\circ} \mathrm{C}$.

Figura 5. 41: Microperfis de oxigênio dissolvido e de $\mathrm{pH}$ nas três células de fluxo no $1^{\circ}$ dia do experimento. Taxa $a_{\text {carreg. }}=0,25 \mathrm{~g} \mathrm{~N} / \mathrm{m}^{2}$ biofilme.dia, Vel. superficial $=1 \mathrm{~m} / \mathrm{h}$ (cél 1), $8 \mathrm{~m} / \mathrm{h}$ (cél 2) e 4 $\mathrm{m} / \mathrm{h}$ (cél 3), $\mathrm{T}=25 \pm 2^{\circ} \mathrm{C}$.

Figura 5. 42: Microperfis de íons amônio $\left(\mathrm{NH}_{4}{ }^{+}\right)$e íons $\mathrm{NO}_{\mathrm{x}}{ }^{-}$nas três células de fluxo no $2^{\circ}$ dia do experimento. Taxa carreg. $=0,25 \mathrm{~g} \mathrm{~N} / \mathrm{m}^{2}$ biofilme.dia, Vel. superficial $=1 \mathrm{~m} / \mathrm{h}$ (cél 1), $8 \mathrm{~m} / \mathrm{h}$ (cél 2) e $4 \mathrm{~m} / \mathrm{h}$ (cél 3), $\mathrm{T}=25 \pm 2^{\circ} \mathrm{C}$.

Figura 5. 43: Microperfis de oxigênio dissolvido e de $\mathrm{pH}$ das três células de fluxo no $3^{\circ}$ dia do experimento. Taxa carreg. $=0,25 \mathrm{~g} \mathrm{~N} / \mathrm{m}^{2}$ biofilme.dia, Vel. superficial $=1 \mathrm{~m} / \mathrm{h}($ cél 1), $8 \mathrm{~m} / \mathrm{h}$ (cél 2) e $4 \mathrm{~m} / \mathrm{h}$ (cél 3), $\mathrm{T}=25 \pm 2^{\circ} \mathrm{C}$.

Figura 5. 44: Microperfis de íons amônio e de íons $\mathrm{NO}_{\mathrm{x}}{ }^{-}$dos biofilmes das três células de fluxo no $4^{\circ}$ dia do experimento. Taxa carreg. $=0,25 \mathrm{~g} \mathrm{~N} / \mathrm{m}^{2}$ biofilme.dia, Vel. superficial $=1 \mathrm{~m} / \mathrm{h}$ (cél 1), $8 \mathrm{~m} / \mathrm{h}$ (cél 2) e 4 $\mathrm{m} / \mathrm{h}$ (cél 3), $\mathrm{T}=25 \pm 2^{\circ} \mathrm{C}$.

Figura 5. 45: Perfis de OD e de pH dos biofilmes das três células de fluxo no $5^{\circ}$ dia do experimento. Taxa ${ }_{\text {carreg. }}=0,25 \mathrm{~g} \mathrm{~N} / \mathrm{m}^{2}$ biofilme.dia, Vel. superficial $=1 \mathrm{~m} / \mathrm{h}$ (cél 1), $8 \mathrm{~m} / \mathrm{h}$ (cél 2) e $4 \mathrm{~m} / \mathrm{h}$ (cél 3), $\mathrm{T}=25 \pm$ $2^{\circ} \mathrm{C}$

Figura 5. 46: Perfis de íons $\mathrm{NH}_{4}^{+}$e de íons $\mathrm{NO}_{\mathrm{x}}^{-}$dos biofilmes das três células de fluxo no $6^{\circ}$ dia do experimento. Taxa carreg. $=0,25 \mathrm{~g} \mathrm{~N} / \mathrm{m}^{2}$ biofilme.dia, Vel. superficial $=1 \mathrm{~m} / \mathrm{h}$ (cél 1), $8 \mathrm{~m} / \mathrm{h}$ (cél 2) e $4 \mathrm{~m} / \mathrm{h}$ (cél 3), $\mathrm{T}=25 \pm 2^{\circ} \mathrm{C}$.

Figura 5. 47: Perfis de OD e de pH dos biofilmes das três células de fluxo no $7^{\circ}$ dia do experimento.

Taxa ${ }_{\text {carreg. }}=0,25 \mathrm{~g} \mathrm{~N} / \mathrm{m}^{2}$ biofilme.dia, Vel. superficial $=1 \mathrm{~m} / \mathrm{h}$ (cél 1), $8 \mathrm{~m} / \mathrm{h}$ (cél 2) e $4 \mathrm{~m} / \mathrm{h}$ (cél 3), $\mathrm{T}=25 \pm$ $2^{\circ} \mathrm{C}$

Figura 5. 48: Perfis de $\mathrm{NH}_{4}{ }^{+}$, íons $\mathrm{NO}_{\mathrm{x}}{ }^{-}$e de $\mathrm{OD}$ dos biofilmes das três células de fluxo, no $8^{\circ}$ dia do experimento. Taxa carreg. $=0,25 \mathrm{~g} \mathrm{~N} / \mathrm{m}^{2}$ biofilme.dia, Vel. superficial $=1 \mathrm{~m} / \mathrm{h}$ (cél 1), $8 \mathrm{~m} / \mathrm{h}$ (cél 2) e $4 \mathrm{~m} / \mathrm{h}$ (cél 3), $\mathrm{T}=25 \pm 2^{\circ} \mathrm{C}$.

Figura 5. 49: Alcalinidade do afluente e dos efluentes das três células de fluxo (1;2 e 3) (à esquerda). Consumo de alcalinidade das três células de fluxo (à direita). Taxa carreg. $=0,25 \mathrm{~g} \mathrm{~N} / \mathrm{m}^{2}$ biofilme.dia, Vel. superficial $=1 \mathrm{~m} / \mathrm{h}$ (cél 1), $8 \mathrm{~m} / \mathrm{h}$ (cél 2) e $4 \mathrm{~m} / \mathrm{h}$ (cél 3), $\mathrm{T}=25 \pm 2^{\circ} \mathrm{C}$.

Figura 5. 50: Valores de $\mathrm{pH}$ no afluente e nos efluentes das três células de fluxo $(1 ; 2$ e 3$)$

Taxa ${ }_{\text {carreg. }}=0,25 \mathrm{~g} \mathrm{~N} / \mathrm{m}^{2}$ biofilme. dia, Vel. superficial $=1 \mathrm{~m} / \mathrm{h}$ (cél 1), $8 \mathrm{~m} / \mathrm{h}$ (cél 2) e $4 \mathrm{~m} / \mathrm{h}$ (cél 3), $\mathrm{T}=25 \pm$ $2^{\circ} \mathrm{C}$

Figura 5. 51: Concentrações de NTK no afluente e nos efluentes das três células de fluxo.

Taxa ${ }_{\text {carreg. }}=0,25 \mathrm{~g} \mathrm{~N} / \mathrm{m}^{2}$ biofilme.dia, Vel. superficial $=1 \mathrm{~m} / \mathrm{h}$ (cél 1), $8 \mathrm{~m} / \mathrm{h}$ (cél 2) e $4 \mathrm{~m} / \mathrm{h}$ (cél 3), T= $25 \pm$ $2^{\circ} \mathrm{C}$

Figura 5. 52: Concentrações dos íons $\mathrm{NO}_{2}{ }^{-}$e $\mathrm{NO}_{3}{ }^{-}$nos efluentes das células de fluxo 1; 2 e 3 .

Taxa ${ }_{\text {carreg. }}=0,25 \mathrm{~g} \mathrm{~N} / \mathrm{m}^{2}$ biofilme. dia, Vel. superficial $=1 \mathrm{~m} / \mathrm{h}$ (cél 1), $8 \mathrm{~m} / \mathrm{h}$ (cél 2) e $4 \mathrm{~m} / \mathrm{h}$ (cél 3), $\mathrm{T}=25 \pm$ $2^{\circ} \mathrm{C}$ 


\section{ÍNDICE DE TABELAS}

Tabela 3. 1: Tipo de corrente iônica em diferentes métodos eletroanaliticos. 7

Tabela 3. 2: Tipos de sensores utilizados na determinação de concentrações das espécies de enxofre. . 20

Tabela 4. 1- Equipamentos do Laboratório de Microssensores, pertencente ao Laboratório de Microssensores (SHS- EESC - USP).

Tabela 4. 2: Composição eletrolítica e especificação das membranas dos microssensores potenciométricos.

Tabela 4. 3: Íons interferentes (B) analisados para os microssensores de $\mathrm{pH}, \mathrm{NH}_{4}^{+} \mathrm{e} \mathrm{NO}_{3}^{-} \ldots \ldots \ldots \ldots \ldots \ldots . . . . . . .40$

Tabela 4. 4 - Quantidades de componentes orgânicos e inorgânicos presentes no substrato ................... 47

Tabela 4. 5 - Soluções de sais minerais acrescentadas ao substrato sintético.......................................... 47

Tabela 4. 6: Condições Operacionais adotadas nos experimentos realizados no presente estudo. .......... 51

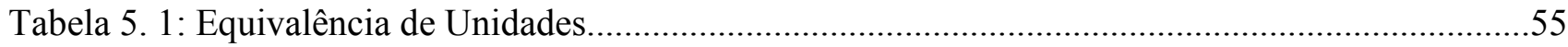

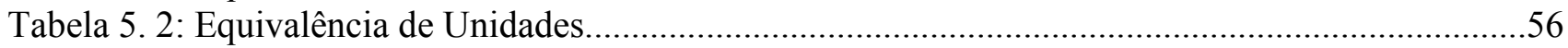

Tabela 5. 3: Valores de $\mathrm{K}_{A, B}^{P O T}$ obtidos e teóricos para as espécies interferentes de microssensores de $\mathrm{NH}_{4}^{+}$.

Tabela 5. 4: Valores de $\mathrm{K}_{A, B}^{P O T}$ obtidos e teóricos para as espécies interferentes de microssensores de $\mathrm{pH}$.

Tabela 5. 5: Valores de $\mathrm{K}_{A, B}^{P O T}$ obtidos e teóricos para as espécies interferentes de microssensores de $\mathrm{NO}_{3}^{-}$

Tabela 5. 6: Valores de pH, alcalinidade e DQO no $4^{\circ}$ dia de operação da célula de fluxo. .................. 70

Tabela 5. 7: Valores de $\mathrm{pH}$ no afluente e efluente da célula de fluxo no $5^{\circ}$ dia de operação................... 70

Tabela 5. 8: Resultados das análises físico-químicas realizadas no $6^{\circ}$ dia do experimento..................... 71

Tabela 5. 9: Valores de $\mathrm{pH}$ e alcalinidade do último dia de operação da célula de fluxo. ...................... 71

Tabela 5. 10:Alcalinidade dos efluentes das três células de fluxo e do substrato sintético das mesmas. 88

Tabela 5. 11: Valores de $\mathrm{pH}$ no afluente e nos efluentes das três células de fluxo. .............................. 88

Tabela 5. 12: Concentrações de NTK $(\mathrm{mg} / \mathrm{L})$ do substrato sintético e dos efluentes das três células de

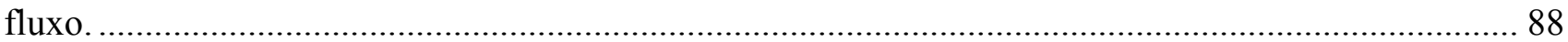

Tabela 5. 13: Concentrações de íons $\mathrm{NO}_{2}{ }^{-}(\mathrm{mg} / \mathrm{L})$ dos efluentes das três células de fluxo..................... 88

Tabela 5. 14: Valores de $\mathrm{pH}$ obtidos por meio de macroeletrodos e de microeletrodos de $\mathrm{pH}$............... 89

Tabela 5. 15: Valores de concentrações de $\mathrm{NO}_{\mathrm{x}}{ }^{-}$obtidos por meio de microeletrodos e da técnica FIA.90

Tabela 5. 16:Concentrações de NTK determinadas por análise físico-químicas.................................... 90

Tabela 5. 17: Valores de $\mathrm{pH}$ determinados mediante o uso de macroeletrodo e de microeletrodo......... 99

Tabela 5. 18: Valores de concentrações de íons $\mathrm{NH}_{4}{ }^{+}$determinados mediante realização de análise físico-química (FIA) e através do uso de microssensores de íons $\mathrm{NH}_{4}{ }^{+}$. ............................................ 99 


\begin{tabular}{|c|c|}
\hline Oxigênio Dissolvido & OD \\
\hline Potencial & $\mathrm{E}$ (Volts) \\
\hline Constante dos gases & $\mathrm{R}(8,31451$ Joule/Kelvin. mol) \\
\hline Temperatura & $\mathrm{T}$ (Kelvin e em graus Celsius) \\
\hline Número de mol & $\mathrm{n}$ \\
\hline Constante de Faraday & F (9.6845.10 $0^{4}$ Coulomb/mol) \\
\hline Espécie Reduzida & Red \\
\hline Espécie Oxidada & $\mathrm{Ox}$ \\
\hline elétron & $\mathrm{e}^{-}$ \\
\hline Fluxo de espécies & $\mathrm{J}_{\mathrm{i}}$ \\
\hline Concentração & $\mathrm{C}(\mathrm{mol} / \mathrm{L}-\mathrm{M}$ ou mg/L) \\
\hline direção & $\mathrm{x}$ \\
\hline Gradiente de concentração & $\frac{\partial_{c i}}{\partial_{x}}$ \\
\hline Eletrodo Íon Seletivo & ISE \\
\hline Diferença de Potencial & ddp \\
\hline Coeficiente de seletividade potenciométrico & $\left(\mathrm{K}_{A, B}^{P O T}\right)$ \\
\hline Carga de espécies & $\mathrm{z}$ \\
\hline Atividade & A \\
\hline Corrente & i (Ampere) \\
\hline Coeficiente de Difusão & $\mathrm{D}_{0}\left(\mathrm{~cm}^{2} / \mathrm{s}\right)$ \\
\hline raio & $\mathrm{r}(\mathrm{cm})$ \\
\hline Potencial Hidrogeniônico & $\mathrm{pH}$ \\
\hline Mebrana de troca iônica líquida & Membrana LIX \\
\hline Eletrodo de Trabalho & ET \\
\hline Eletrodo de Guarda & EG \\
\hline
\end{tabular}




\author{
Diâmetro \\ Íon Primário \\ Íon Interferente
}

Célula de Fluxo

$$
\text { Vazão }
$$

Curva Média

Curva Teórica

Coeficiente de Correlação

Demanda Química de Oxigênio

Nitrogênio Total Kjeldahl
$\mathrm{D}(\mu \mathrm{m}$ ou $\mathrm{mm})$

Íon $\mathrm{A}$

Íon B

Cél

$\mathrm{Q}(\mathrm{L} / \mathrm{h}$ ou $\mathrm{mL} / \mathrm{h})$

M

$\mathrm{T}$

$\mathrm{R}^{2}$

DQO

NTK (mg/L) 


\section{SUMÁRIO}

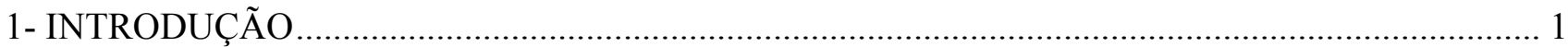

2- OBJETIVOS

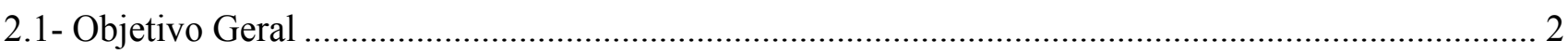

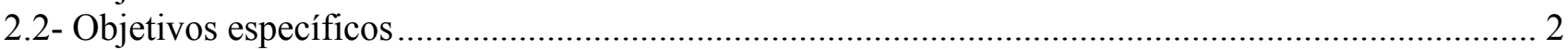

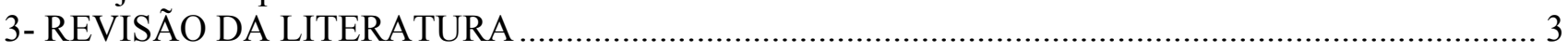

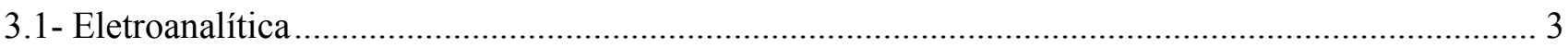

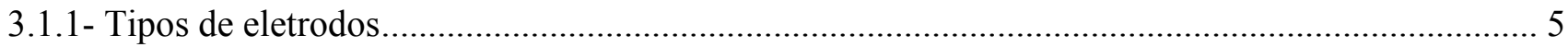

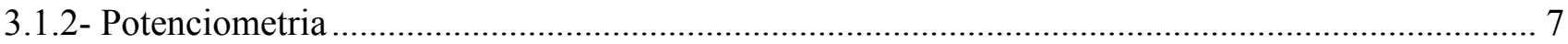

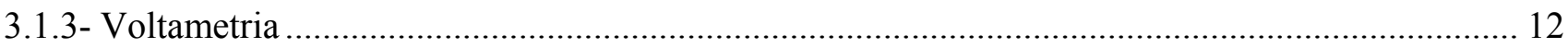

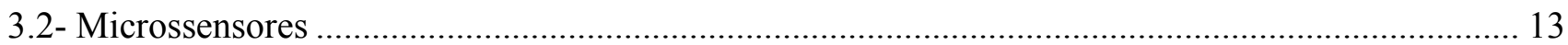

3.2.1- Microssensores para detecção de Oxigênio Dissolvido (OD) ....................................................... 14

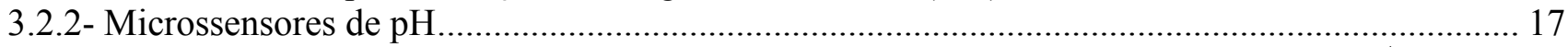

3.2.3- Microssensores para mensuração de íons nitrato $\left(\mathrm{NO}_{3}{ }^{-}\right)$, nitrito $\left(\mathrm{NO}_{2}{ }^{-}\right)$e amônio $\left(\mathrm{NH}_{4}{ }^{+}\right)$........... 19

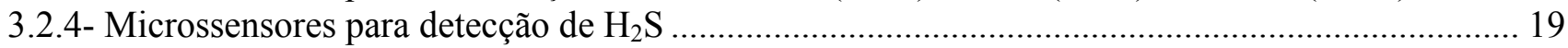

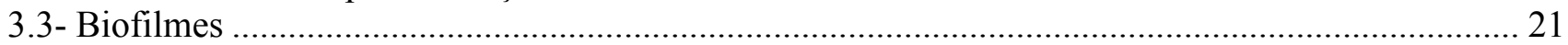

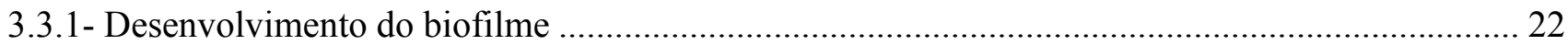

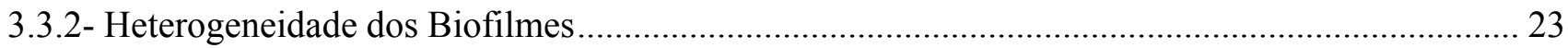

3.3 - Limitações da Técnica de Microperfilação in situ com Microssensores ...................................... 27

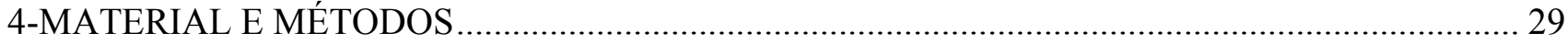

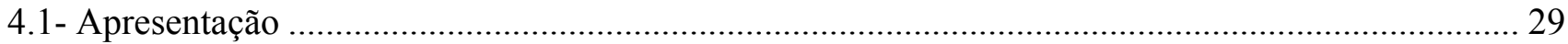

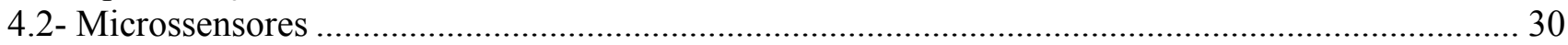

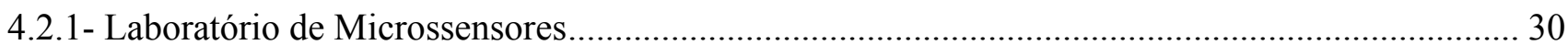

4.2.2- Construção e calibração do microssensor amperométrico de OD ............................................... 31

4.2.3- Construção e calibração dos microssensores potenciométricos de íons nitrato $\left(\mathrm{NO}_{3}{ }^{-}\right)$, nitrito $\left(\mathrm{NO}_{2}{ }^{-}\right.$

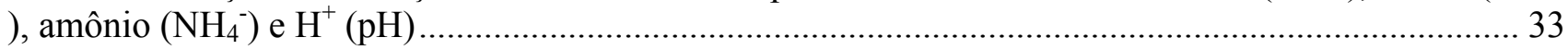

4.2.4-Construção e calibração do microssensor para determinação de $\mathrm{H}_{2} \mathrm{~S}$......................................... 35

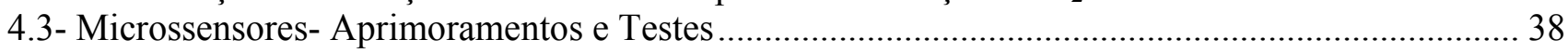

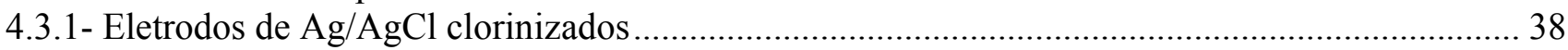

4.3.2- Testes de Seletividade dos sensores potenciométricos........................................................ 39

4.4- Fatores limitantes relacionados à construção e armazenamento dos microssensores ...................... 40

4.4.1- Adaptação e construção de materiais suportes para os microssensores ....................................... 40

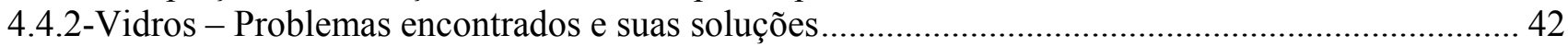

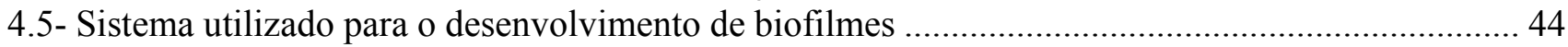

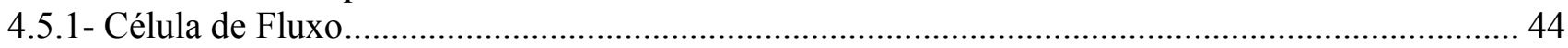

4.5.2- Considerações gerais relacionadas com as células de fluxo ................................................. 46

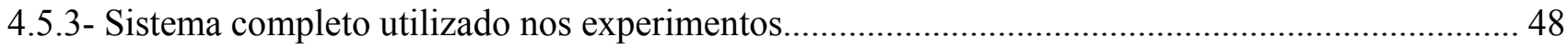

4.5.4- Condições operacionais da célula de fluxo - Experimento 1 ..................................................... 48

4.5.5- Condições operacionais da célula de fluxo - Experimento 2 …............................................. 49

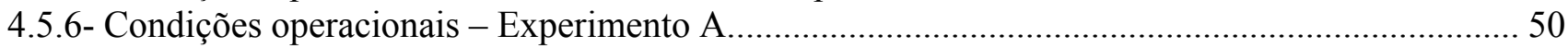

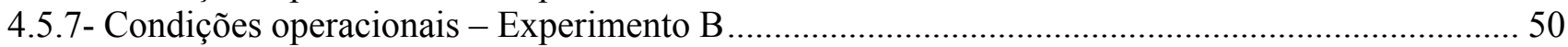

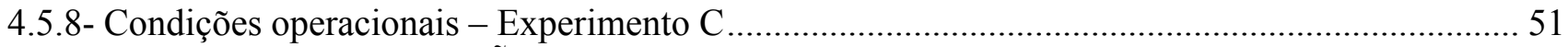

5- RESULTADOS E DISCUSSÃO

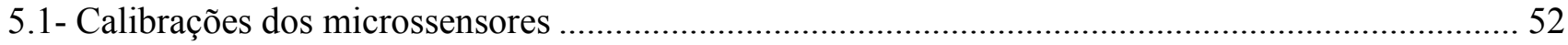


5.1.1- Microssensores de OD

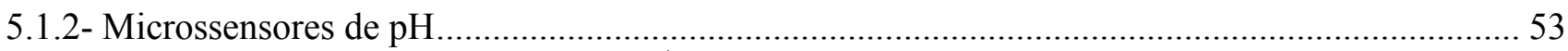

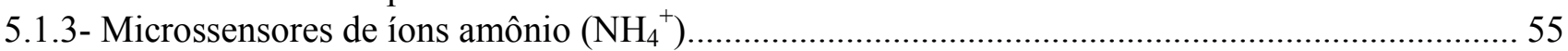

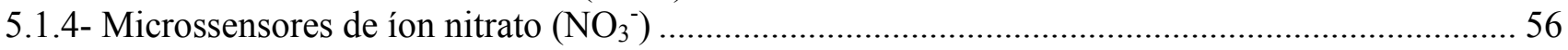

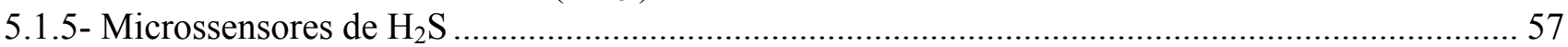

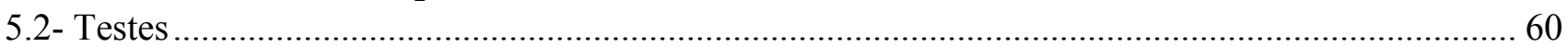

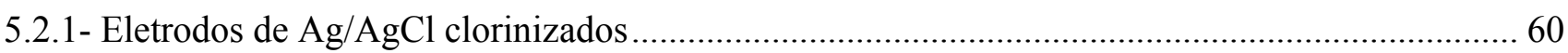

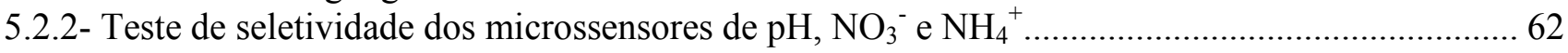

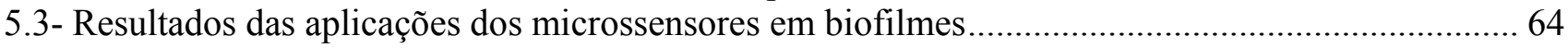

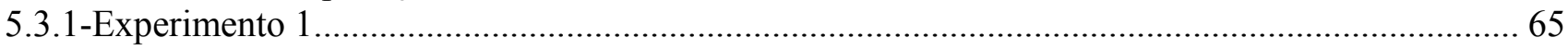

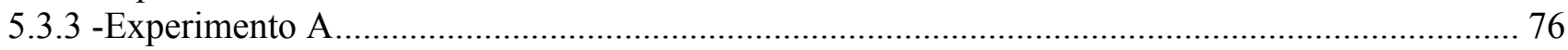

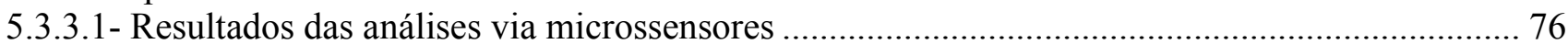

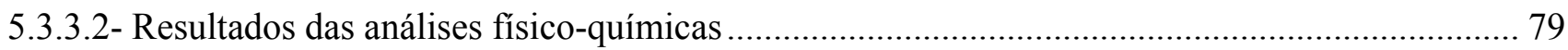

5.3.3.3- Resultados - Microssensores e análises físico-químicas .......................................................... 82

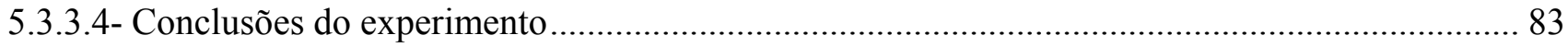

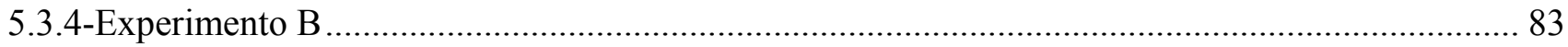

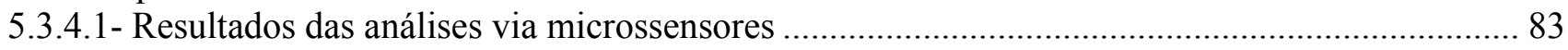

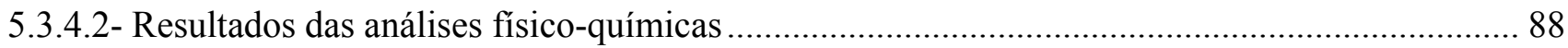

5.3.4.3- Resultados - Microssensores e análises físico-químicas .......................................................... 89

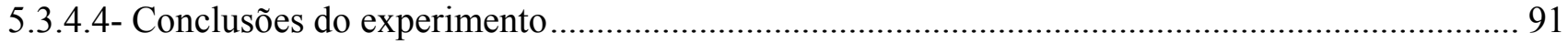

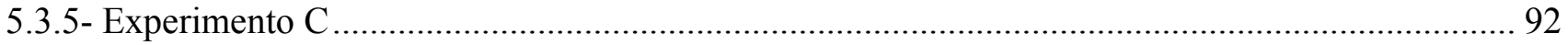

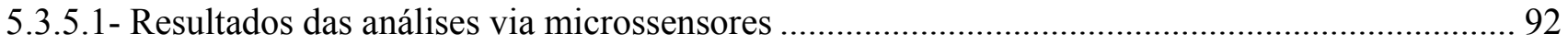

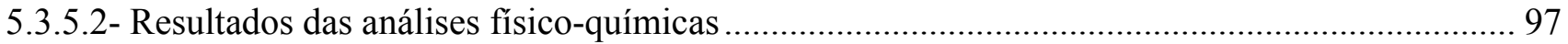

5.3.5.3- Resultados - Microssensores e análises físico-químicas ......................................................... 99

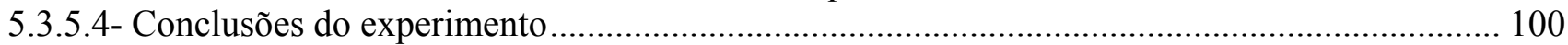

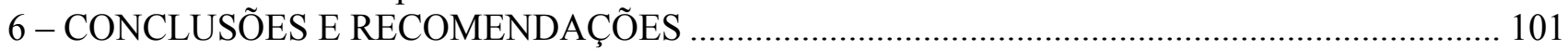

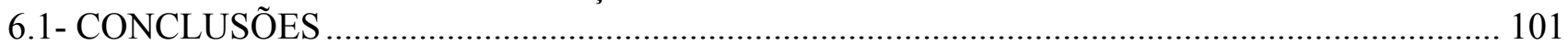

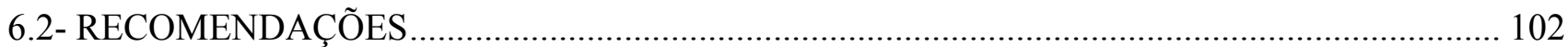

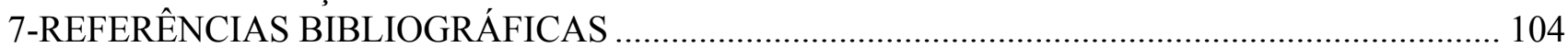




\section{1- INTRODUÇÃO}

A formação de biofilmes e agregados microbianos é pré-requisito para a operação de sistemas de tratamento biológicos e de remoção de nutrientes e de matéria orgânica de águas residuárias. Os reatores onde o crescimento biológico ocorre aderido a um meio sólido, ou "dentro dele", em poros ou canais, são denominados reatores de crescimento agregado ou aderido, ou reatores biológicos de filme fixo. Existem diferentes configurações de sistemas de crescimento agregado e combinações deste tipo. Novas configurações estão sempre surgindo como, por exemplo: filtro aeróbio, filtro aerado submerso, biofiltro aerado submerso e reatores de leito fluidificado/expandido, "biodiscos", etc.

$\mathrm{O}$ conhecimento da atividade do filme microbiano em reatores de biofilme consiste em fator importante para aprimoramento de sua operação e controle. Tais atividades podem ser quantificadas mediante duas escalas de observação: a macro-escala e a micro-escala.

A avaliação da atividade do biofilme na macro-escala pode ser feita mensurando-se as concentrações de componentes químicos selecionados, tanto no afluente quanto no efluente do reator por meio de análises físico-químicas. A partir dos resultados analíticos, torna-se possível a verificação do consumo e produção de elementos específicos realizados pelos microrganismos presentes nos biofilmes. Tal avaliação é adequada quando se deseja estimar o desempenho total de um reator com biofilme. Entretanto, esta não seria apropriada se o objetivo da mesma fosse o de quantificar a atividade de biofilmes localizados em partes específicas do reator - os quais possuem comportamentos desiguais de acordo com as condições distintas sob as quais estão submetidos.

A identificação da atividade microbiana de biofilmes na micro-escala é feita de forma "pontual", de modo que as concentrações de substratos selecionados são determinadas no meio líquido em que o biofilme encontra-se inserido, na superfície e no interior do mesmo. Para este propósito, a aplicação de microssensores amperométricos e potenciométricos é considerada como alternativa bastante interessante, visto que suas dimensões reduzidas viabilizam a efetivação de medições feitas com volume de amostra extremamente pequeno realizadas de forma pouco intrusiva, sem que haja a danificação das estruturas dos biofilmes (LEWANDOWSKI; BEYENAL, 2003).

Diferentes tipos de microssensores têm sido usados como poderosos instrumentos para avaliação de variáveis, como $\mathrm{O}_{2}, \mathrm{NO}_{3}^{-}, \mathrm{NO}_{2}^{-}, \mathrm{pH}, \mathrm{N}_{2} \mathrm{O}, \mathrm{H}_{2} \mathrm{~S}, \mathrm{NH}_{4}^{+}$, potencial redox em biofilmes (JEROSCHEWSKI, P.; STEUCKART, C.; KUHL, M., 1996; DE BEER et al., 1997).

O Departamento de Hidráulica e Saneamento (EESC-USP- São Carlos-SP) atua na área de bioengenharia, mais especificamente no estudo de biofilmes em reatores de tratamento biológico de 
resíduos, desde o início da década de 80 e o mesmo vem obtendo resultados positivos e práticos neste ramo. O Departamento dispõe de um Laboratório de Microssensores para a construção dos mesmos, entretanto até o início desse estudo apenas microssensores para detecção de oxigênio dissolvido haviam sido construídos com a expressiva e essencial atuação do técnico especializado Antonio Wagner Lamon.

Portanto, o objetivo da presente pesquisa foi o de construir microssensores potenciométricos e amperométricos para análise de concentrações de substratos selecionados em biofilmes aplicados ao tratamento de água residuária, a fim de se verificar a efetividade da aplicação dos mesmos em biofilmes desenvolvidos sob diferentes condições experimentais.

\section{2- OBJETIVOS}

\section{1- Objetivo Geral}

Avaliar a aplicabilidade dos microssensores construídos para análise de oxigênio dissolvido (OD), $\mathrm{pH}, \mathrm{H}_{2} \mathrm{~S}$ e íons nitrito $\left(\mathrm{NO}_{2}{ }^{-}\right)$, nitrato $\left(\mathrm{NO}_{3}{ }^{-}\right)$, amônio $\left(\mathrm{NH}_{4}{ }^{+}\right)$, em biofilmes empregados para nitrificação de águas residuárias.

\section{2- Objetivos específicos}

Os objetivos específicos foram:

Operar reatores de bancada do tipo célula de fluxo nos quais biofilmes foram desenvolvidos e verificar se as mesmas foram adequadas para desenvolvimento dos mesmos.

Avaliar o tempo de operação necessário para formação de zonas anaeróbias no interior dos biofilmes aderidos nas células de fluxo, sob condições operacionais distintas.

Desempenhar testes de seletividade dos microssensores de detecção de íons $\mathrm{H}^{+}$, nitrato, nitrito e amônio.

Verificar, mediante aplicação de microssensores e por meio das análises físico-químicas, se biofilmes nitrificantes se desenvolveram nas células de fluxo operadas. 


\section{3- REVISÃO DA LITERATURA}

\section{1- Eletroanalítica}

A química eletroanalítica engloba um conjunto de métodos analíticos baseados nas propriedades elétricas de uma solução do analito (espécie que se deseja detectar) quando o mesmo faz parte de uma célula eletroquímica. Tais técnicas são capazes de proporcionar baixos limites de detecção e uma elevada quantidade de informações que caracterizam e descrevem eletroquimicamente determinados sistemas. Essas informações compreendem a estequiometria, a velocidade de transferência de massa e de carga interfacial, a extensão de adsorção e as velocidades e constantes de equilíbrio de reações químicas.

Imensa gama de métodos eletroanalíticos já foi proposta. Dentre eles, os que são comumente aplicados encontram-se ilustrados na Figura 3.1. Como podem ser observados na Figura, os métodos interfaciais, que são aqueles baseados em fenômenos que ocorrem na interface eletrodo-solução, podem ser divididos em inúmeras categorias, enquanto que o mesmo não é feito com os métodos de solução como um todo, os quais se baseiam nos processos que ocorrem no interior da solução (SKOOG; HOLLER; NIEMAN, 2002).

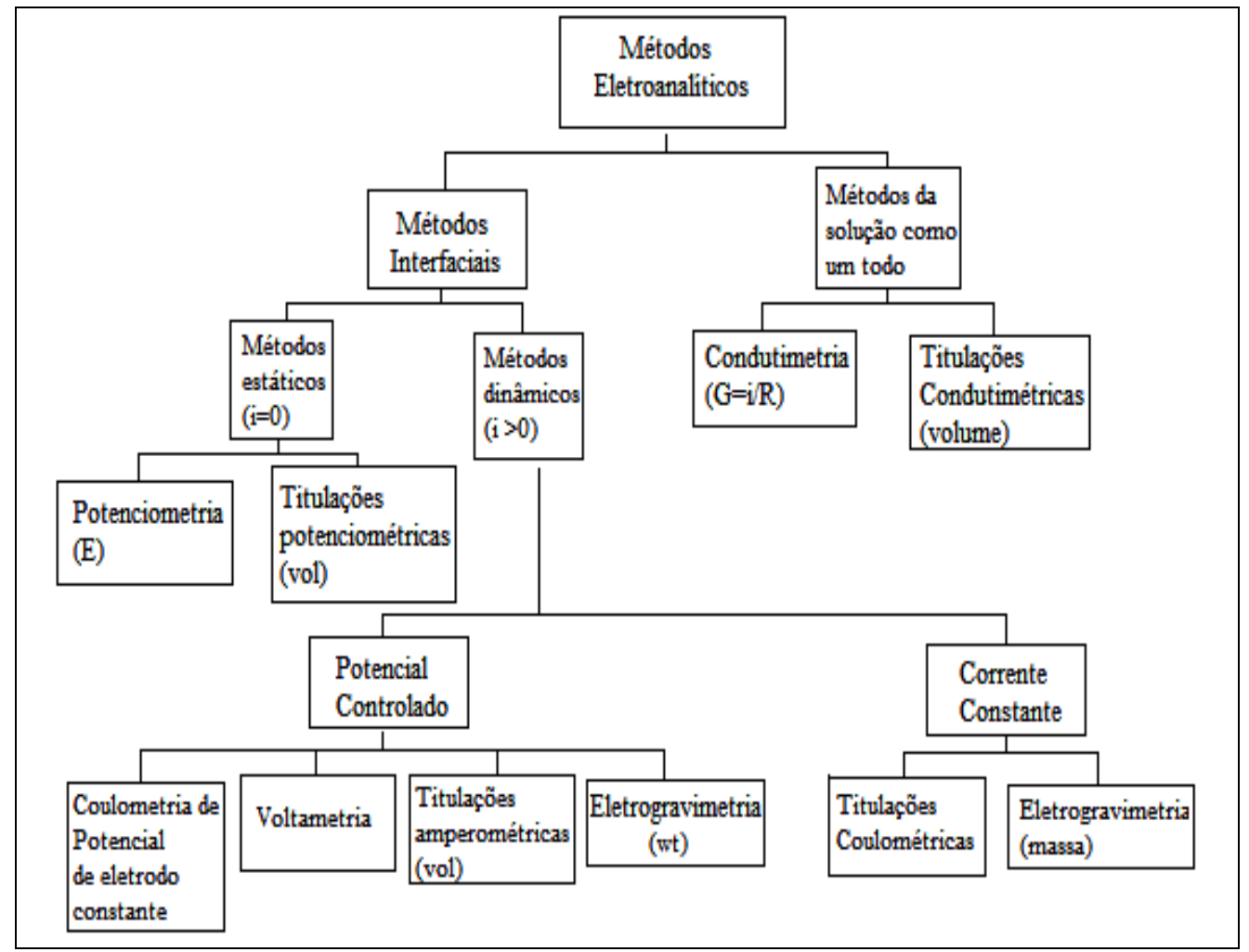

Figura 3. 1: Métodos eletroanalíticos: sua classificação geral (Fonte: SKOOG; HOLLER; NIEMAN, 2002). 
Para que a compreensão dos métodos citados anteriormente seja possível, faz-se necessário o conhecimento da teoria de base dos mesmos, a Eletroquímica. Para tratar da Eletroquímica de modo concreto será considerada primeiramente a célula eletroquímica, a qual é constituída por dois condutores elétricos designados por eletrodos, cada um dos quais se encontra imerso em uma solução eletrolítica adequada, conforme exemplo apresentado na Figura 3.2. Exteriormente os eletrodos são conectados por um condutor metálico e uma ponte salina mantém o contato elétrico entre os dois eletrólitos. Existem também células em que os eletrodos partilham o mesmo eletrólito, as quais são denominadas de células sem junção líquida.

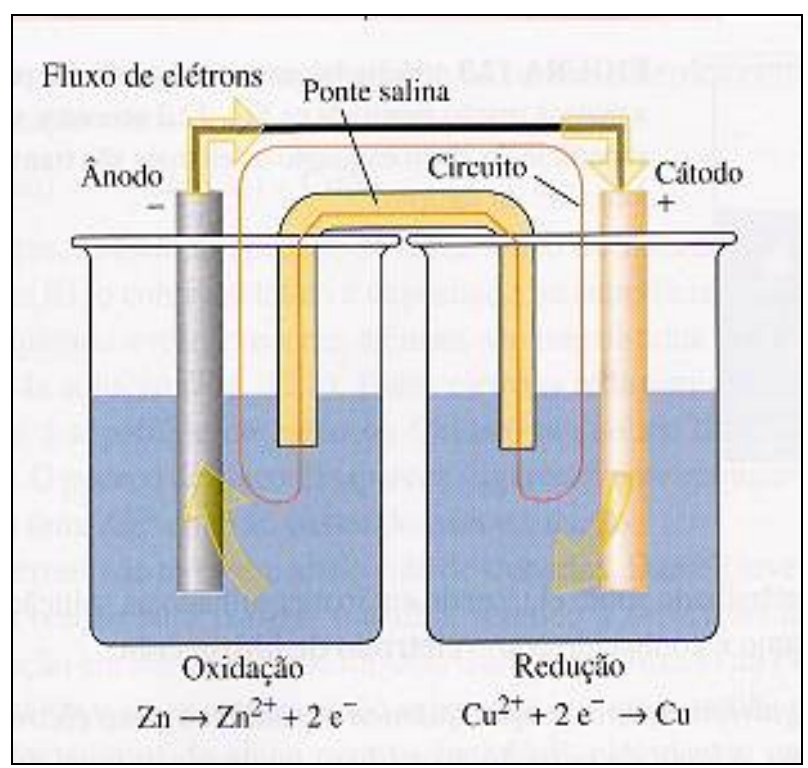

Figura 3. 2: Ilustração de célula eletroquímica (Fonte: BETTIN; TEIXEIRA; SANTOS, 2006).

Existem dois tipos de células eletroquímicas, que são conhecidas como galvânicas e eletrolíticas. Nas células galvânicas ocorre transformação da energia obtida em uma reação química espontânea em energia elétrica, por meio do movimento dos elétrons. Já as células eletrolíticas consistem em células que convertem energia elétrica fornecida exteriormente por uma fonte de alimentação, em energia química, permitindo que a direção da reação do eletrodo seja alterada (BRETT, A.; BRETT, C., 1993).

A condução elétrica das cargas através das células eletroquímicas se dá por três processos distintos:

i) Nos eletrodos e no condutor externo a carga é transportada pelos elétrons que se movem de um eletrodo em direção ao outro;

ii) Nas soluções os ânions e os cátions são responsáveis pelo transporte das cargas entre os eletrodos. Tal migração é conhecida como fluxo de corrente elétrica; 
iii) Nas superfícies dos eletrodos ocorrem reações de oxidação/redução, nas quais a captação e liberação de elétrons acontecem.

O potencial (E) das células eletroquímicas pode ser calculado a partir dos potenciais gerados nas semi-reações que se dão nos eletrodos (Equação 3.1).

$$
\mathrm{E}_{\text {célula }}=\mathrm{E}_{\text {catodo }}-\mathrm{E}_{\text {anodo }}
$$

A Equação de Nernst (Equação 3.2) relaciona as atividades das espécies envolvidas com o potencial do eletrodo (E) da meia-reação e o seu potencial de eletrodo padrão $\left(\mathrm{E}^{\Theta}\right)$, que é o potencial relativo ao potencial do eletrodo de hidrogênio padrão.

$$
\mathrm{E}=E_{\frac{o x}{r e d}}^{\circ}-\frac{R T}{n F} \ln \frac{(\text { red })}{(o x)}
$$

$\mathrm{R}$ : constante dos gases $\left(8,31451 \mathrm{~J} \cdot \mathrm{K}^{-1} \cdot \mathrm{mol}^{-1}\right)$, T: temperatura $(\mathrm{K})$, n: número estequiométrico de elétrons transferidos por cada espécie, F: constante de Faraday $\left(9.6485 .10^{4} \mathrm{C}_{\mathrm{mol}}{ }^{-1}\right)$.

Para a meia-reação genérica de redução tem-se (Equação 3.3),

$$
\text { Ox }+ \text { ne }^{-} \leftrightarrow \text { Red }
$$

Vale ressaltar que as células galvânicas podem ser transformadas em células eletrolíticas mediante a aplicação de potencial superior ao da célula galvânica, e por meio do emprego de corrente contínua, a qual assegura que o fluxo eletrônico mantenha um único sentido.

\subsection{1- Tipos de eletrodos}

Existem diversos tipos de materiais que são utilizados como eletrodos, com imensa variedade de comportamento. Segundo MacInnes ${ }^{1}$ (1961 apud BRETT, A.; BRETT, C., 1993) os eletrodos metálicos são divididos em três categorias: eletrodo de $1^{\text {a }}$ ordem, de $2^{\text {a }}$ ordem e eletrodos inertes.

O eletrodo de $1^{\mathrm{a}}$ ordem é constituído por um metal puro que está em equilíbrio com os seus cátions em solução. Assim, este tem sua aplicação voltada para determinação da concentração de cátions em amostras. Como exemplo deste, pode ser citado o eletrodo constituído de lâmina de prata $(\mathrm{Ag})$ imersa em solução de $\mathrm{AgNO}_{3}\left(\mathrm{Ag} / \mathrm{Ag}^{+}\right)$.

Os eletrodos de $2^{\mathrm{a}}$ ordem consistem em eletrodos metálicos mergulhados em solução contendo ânions que formam sais moderadamente solúveis com os íons metálicos, ou também pode ser um metal revestido com o referido sal. O principal exemplo desta categoria são os eletrodos de calomelano

\footnotetext{
${ }^{1}$ MACINNES, D.A. (1961). Principles of Electrochemistry, Dover, New York.
} 
$\left(\mathrm{Hg}\left|\mathrm{Hg}_{2} \mathrm{Cl}_{2}\right| \mathrm{Cl}^{-}\right)$. A atividade do sal, estando este quase que inteiramente na fase sólida, pode ser considerada como unitária. Portanto, o potencial é apenas função da atividade do ânion.

Esses sistemas são muito utilizados como eletrodos de referência, visto que o baixo produto de solubilidade dos sais proporciona um potencial muito estável. Outros exemplos são: $\mathrm{Ag}|\mathrm{AgCl}| \mathrm{Cl}^{-}$e, para soluções alcalinas, $\mathrm{Hg}|\mathrm{HgO}| \mathrm{OH}^{-}$.

Os eletrodos de referência são usados para proporcionar um valor de potencial que servirá como um referencial na obtenção de diferenças de potenciais. Assim, um eletrodo de referência eficiente deve necessariamente possuir um potencial que se mostra estável com o tempo e temperatura e que não seja alterado devido a pequenas perturbações do sistema, como passagens de correntes de valores reduzidos. Além dos exemplos de eletrodos de referência já citados, outros tipos desses podem ser mencionados como eletrodos de referência de hidrogênio, eletrodo de vidro, e eletrodo inerte.

O último (eletrodo inerte) consiste de uma fonte de elétrons ou de um receptor de elétrons o qual permite a transferência de elétrons sem que haja a participação do eletrodo na reação, como é o caso dos eletrodos do primeiro e segundo tipo. Por esse motivo esses eletrodos são conhecidos como eletrodos inertes ou redox. Os primeiros tipos de materiais que foram empregados como eletrodos redox se trataram de metais nobres, como ouro e platina, bem como o mercúrio. Atualmente essa designação inclui diversos outros tipos de materiais tais como carbono vítreo, diferentes tipos de grafite, e semicondutores óxidos. A aplicação destes se dá quando a finalidade da análise é o estudo de um equilíbrio reversível de oxidação - redução.

Os eletrodos que não se enquadram nas categorias descritas nesse texto são chamados de eletrodos modificados. Neste tipo de eletrodos a superfície do eletrodo é deliberadamente alterada por adsorção, por cobertura física, ou por ligações de espécies específicas. O resultado é o bloqueamento do acesso direto ao eletrodo, inibindo alguns processos de eletrodo e promovendo outros. Portanto, modificações podem ser consideradas como alterações vantajosas por proporcionarem, na maioria dos casos, a obtenção de seletividades elevadas (NATAN; WRIGHTON, 1990).

É de suma importância considerar o movimento dos íons entre o anodo e o catodo em soluções eletrolíticas. As espécies iônicas são transportadas para a superfície dos eletrodos através de três mecanismos: convecção, difusão e migração. O movimento dos íons por convecção resulta da agitação mecânica ou térmica. Já a difusão é devida a um gradiente de concentração iônico entre a superfície do eletrodo e o seio da solução, enquanto que a migração se deve a efeitos do campo elétrico. Assim enquanto que a difusão ocorre para todas as espécies, a migração afeta apenas as espécies carregadas.

A difusão é descrita pela primeira Lei de Fick (Equação 3.4): 


$$
J i=-D i \cdot \frac{\partial_{c i}}{\partial_{x}}
$$

onde $\mathrm{J}_{\mathrm{i}}$ é o fluxo de espécies $i$ de concentração $\mathrm{c}_{\mathrm{i}}$ na direção $\mathrm{x}$, e $\partial_{\mathrm{c} i} / \partial_{\mathrm{x}}$ é o gradiente de concentração. $\mathrm{D}_{\mathrm{i}}$ é um fator de proporcionalidade entre o fluxo e o gradiente de concentração, conhecido como coeficiente de difusão. O sinal negativo surge porque o fluxo das espécies tende a anular o coeficiente de concentração.

O tipo de corrente iônica que se dá em cada método eletroanalítico difere de acordo com o princípio dos mesmos, como pode ser observado na Tabela 3.1:

Tabela 3. 1: Tipo de corrente iônica em diferentes métodos eletroanaliticos.

\begin{tabular}{|c|c|}
\hline Método & Tipo de corrente iônica \\
\hline \hline Condutimetria & Migração \\
\hline Potenciometria & Nenhuma \\
\hline Voltametria e Polarografia & Difusão \\
\hline Métodos Eletrolíticos & Difusão, Convecção, Migração \\
\hline Titulações Amperométricas & Difusão \\
\hline
\end{tabular}

Fonte: GODINHO, 2003.

Como no presente estudo se utilizaram de forma expressiva as técnicas de potenciometria e voltametria, o enfoque a partir deste ponto será o esclarecimento do embasamento teórico das mesmas, aliados a origem de ambas.

\subsection{2- Potenciometria}

A base da potenciometria foi estabelecida por Nernst, em 1888, quando foi descrito por ele o aparecimento do potencial de eletrodo entre um metal e uma solução contendo íons deste metal. Nernst também desvendou naquela época o surgimento de um potencial redox entre um metal inerte e uma solução contendo um sistema redox (KUBOTA; FERNANDES; NETO, 2001).

O primeiro sensor potenciométrico empregado para detecção da acidez de soluções aquosas foi o eletrodo de hidrogênio, proposto por Nernst $^{2}$ em 1897 (NERNST, 1897 apud KUBOTA; FERNANDES; NETO, 2001). Contudo, devido a sua complexidade de operação esse não era passível de aplicação. Cremer ${ }^{3}$ (1906 apud KUBOTA; FERNANDES; NETO, 2001) desenvolveu o eletrodo de vidro e este foi aperfeiçoado por Haber e Klemensiewicz. Carlsberg propôs a escala de pH, a qual era indispensável para definição da influência da acidez sobre uma série de reações enzimáticas

\footnotetext{
2 NERNST, W. (1897). Ber.Deutsch.Chem. Ges. v.30, p.1547.

${ }^{3}$ CREMER, M. (1906). Z. Biol. v. 47, p.562.
} 
(RUZICKA, 1997). Concomitantemente, as empresas Beckman e Radiometer comercializaram o primeiro medidor de $\mathrm{pH}$, em 1935 (BECKMAN, 1987).

Os eletrodos potenciométricos denominados íon seletivos (ISE) foram desenvolvidos em 1957 com os trabalhos teóricos de Eisenman ${ }^{4}$ e Nikolski ${ }^{5}$. Estes dispositivos são constituídos por um eletrodo de referência interno mergulhado em uma solução de referência que se encontra fisicamente separada da solução do analito, devido à presença de uma membrana na ponta de tais sensores.

Nove anos depois, Ross (1967) propôs um novo conceito de eletrodo íon seletivo, o de membrana liquida. Moody, Oke e Thomas (1970) aplicaram pela primeira vez eletrodos de membrana liquida a base de PVC, sendo que a introdução de tal material na composição da membrana simplificou bastante a construção dos ISEs.

A inovação que seguiu as citadas anteriormente consistiu na aplicação desses dispositivos em análises de substâncias biológicas não-iônicas realizadas a partir da imobilização de um material biologicamente ativo, comumente enzimas, na membrana dos ISE. Estes são denominados atualmente como biossensores potenciométricos.

É possível que a mais recente evolução dos ISE tenha ocorrido nos anos 70 e 80, quando foi desenvolvido o transistor de efeito de campo seletivo a íons (ISFET), no qual a amplificação do sinal é feita diretamente na membrana em contato com a solução, em vez de ser feita no instrumento de medida. Estes se destacam devido a sua capacidade de miniaturização e a possibilidade de serem empregados em estudos in vivo (JANATA, 1994). Uma cronologia do desenvolvimento da potenciometria encontra-se ilustrada na Figura 3.3.

Diante dos inúmeros progressos aqui descritos, os ISEs passaram a ser considerados como um importante subgrupo dos sensores eletroquímicos, devido a sua versatilidade, portabilidade, tamanho reduzido, baixo consumo de energia e baixo custo (BAKKER; BUHLMANN; PRETSCH, 1999).

Os ISEs baseados em membranas são compostos por membranas poliméricas de PVC nas quais se localizam os componentes principais desse tipo de sensor que são os portadores iônicos neutros ou carregados, chamados de ionóforos.

\footnotetext{
${ }^{4}$ EISENMAN, G.; RUDIN, D.O.; CASBY, J.U. (1957). Glass electrode for measuring sodium ion. Science, v.126, p.831834.

${ }^{5}$ NIKOLSKI, B.P.; SCHULTZ, M. M. (1962). Zh. Fiz. Khim. v.36, p.704.
} 


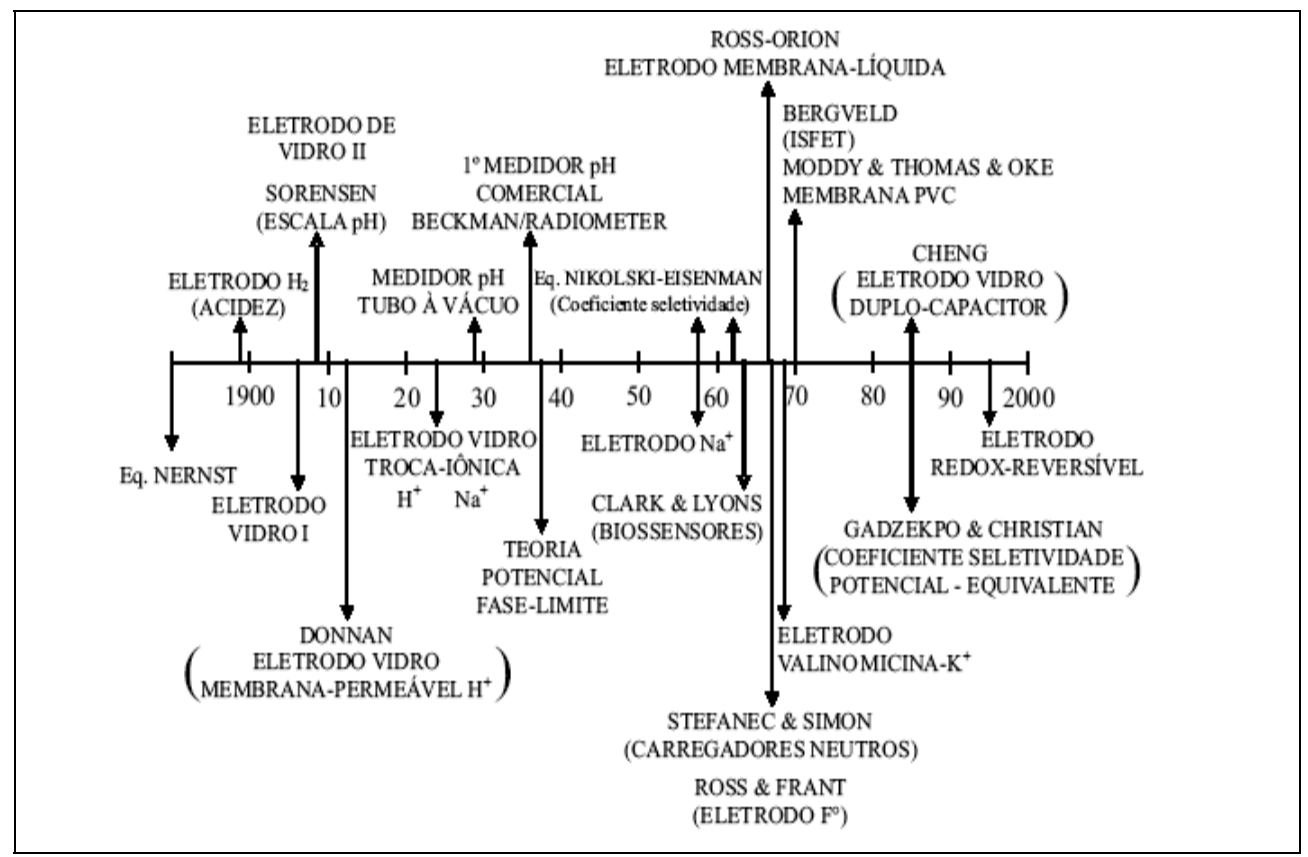

Figura 3. 3: Cronologia do desenvolvimento da potenciometria (Fonte: KUBOTA; FERNANDES; NETO, 2001).

Os ionóforos se ligam seletivamente aos íons que se deseja analisar (primário) principalmente por meio de reações de complexação, e ao mesmo tempo discriminam os íons interferentes. Os mesmos são conhecidos como agentes portadores de íons, devido ao fato de que estes compostos catalisam o transporte de íons através das membranas hidrofóbicas e também por que os mesmos, os quais são geralmente macro ciclos, promovem o transporte de íons por troca de espécies entre macros ciclos adjacentes. A Figura 3.4 ilustra alguns agentes complexantes utilizados como portadores iônicos.

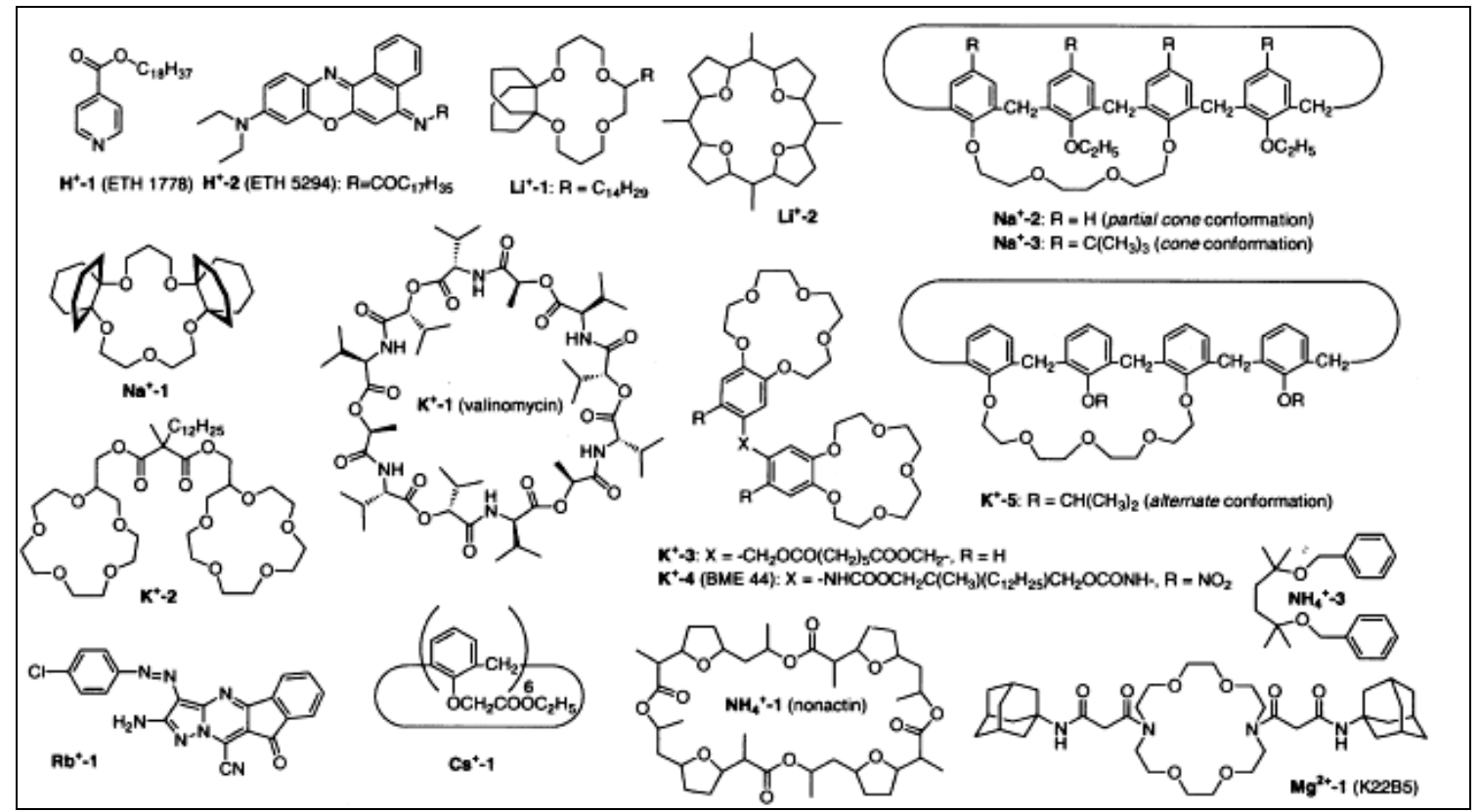

Figura 3. 4: Fórmulas estruturais de ionóforos cátion - seletivos (Fonte: BAKKER; BUHLMANN; PRETSCH, 1999). 
Tais ionóforos podem ser de dois tipos, neutros ou carregados positivamente ou negativamente. Entretanto, Buhlmann et al. (1995) e Yajima et al. (1997) constataram experimentalmente que os ISEs de membrana composta por ionóforos neutros sem que sais lipofílicos tivessem sido adicionados na mesma, se comportavam de forma independente à concentração do analito. Consequentemente, o uso de sais lipofílicos estabeleceu-se tanto para sistemas cátion-seletivo e ânion-seletivo baseados em ionóforos neutros. Às membranas de tais sistemas adicionam-se respectivamente, sais derivados do tetrafenilborato e sais lipofílicos de amônia quaternária.

Desde o desenvolvimento dos ISEs baseados em membranas, surgiram muitas controvérsias concernentes ao seu funcionamento. Inicialmente, um mecanismo intensivamente disseminado foi o embasado no potencial de Donnan, o qual afirmava que a distribuição desigual de íons entre os dois lados da membrana semipermeável ocorria quando os íons permeavam a mesma gerando um equilíbrio eletroquímico e estabelecendo consequentemente um potencial elétrico (MODDY; OKE; THOMAS, 1970). Contudo, houve um mecanismo que foi mais difundido que este primeiro, o baseado na troca iônica. Posteriormente, tendo sido provado por Teorell ${ }^{6}$ e Meyer $^{7}$ (1936 apud FERNANDES; KUBOTA; NETO, 2001) que o último mecanismo não podia ser aplicado para explicar o desenvolvimento do potencial em um ISE, foi proposto o modelo do potencial de fase-limite (boundarypotential). No entanto o conceito teórico da membrana porosa contendo cargas em sítios fixos foi conservado.

Em seguida, Pungor e Tóth (1970) inferiram que o potencial se desenvolvia apenas na superfície do eletrodo. Dessa forma, atualmente o conceito da dupla-camada elétrica e duplo capacitor, com ênfase na interface eletrodo-solução tem sido a proposta mais coerente no que diz respeito ao desenvolvimento do potencial elétrico nos ISEs. Entretanto esta teoria ainda não foi totalmente estabelecida e vários estudos vêm sendo realizados para elucidação da mesma (HIRATA; MIZUTANI; YOKOYAMA, 1999; FAWCETT et al., 1998).

Para compreensão do modelo da dupla camada elétrica é importante ter-se em mente alguns conceitos fundamentais. É conhecido que uma bateria ou uma pilha gera uma diferença de potencial (ddp) mediante a ocorrência de reação redox. De modo contrário, um capacitor eletrolítico é um dispositivo capaz de armazenar cargas elétricas, através de duas placas paralelas entre as quais há um isolante ou dielétrico onde não ocorre nenhuma reação redox. Ademais, quando as placas carregadas

\footnotetext{
${ }^{6}$ TEORELL, T. (1935). An attempt to formulate a quantitative theory of membrane permeability. Proc. Soc. Exp. Bio. Med., v.33, p.282-285.

${ }^{7}$ MEYER, K.H.; SIEVERS, J.F. (1936). The permeability of membranes I - The theory of ionic permeability I.Helv. Chim. Acta, v.19, p.649-987.
} 
são conectadas nenhuma corrente flui, condição básica para a medida de diferença de potencial (ddp) de um ISE. Assim sendo, conclui-se que eletrodos íon-seletivo são mais comparáveis a um capacitor eletrolítico do que a uma bateria.

No momento em que o eletrodo é imerso em uma solução eletrolítica, embora não haja ddp nem campo elétrico através da interface, a mesma pode não estar em equilíbrio possibilitando a ocorrência de uma transferência de carga. Quando a transferência de carga acontece do eletrodo para uma espécie iônica positiva em solução, o eletrodo fica positivamente carregado e a solução adquire carga negativa. Tal acontecimento eletrifica a interface. A separação de cargas na interface implica na geração de uma ddp e de um campo elétrico, o qual afeta a velocidade da reação eletroquímica. Dessa maneira a energia da reação química é transformada em energia elétrica.

Tratando-se, ainda, da imersão do eletrodo em solução eletrolítica, porém focalizando agora no modelo da dupla-camada elétrica citado anteriormente, tem-se que quando um eletrodo de membrana é imerso em uma solução eletrolítica, uma dupla camada é formada, contendo cargas na superfície. Desde que ambas as camadas, a externa e a interna à membrana, estejam em contato com uma solução eletrolítica, duas duplas camadas são desenvolvidas, uma em cada lado da membrana, sendo que a membrana pode ser feita de qualquer material dielétrico ou semicondutor, o qual pode adsorver cátions e ânions em seus sítios ativos. A ddp é então obtida pela diferença de potencial na interface externa e interna à membrana. Por conseguinte, o potencial de membrana é desenvolvido a partir das duas interfaces que armazenam cargas sobre a superfície através da adsorção na dupla camada (KUBOTA; FERNANDES; NETO, 2001).

Quando os sensores íon seletivos são aplicados em amostras, a fim de se determinar a concentração das espécies químicas presentes nas mesmas, a concentração do analito é obtida relacionando-se o potencial da membrana com o potencial de eletrodo de referência apropriado.

O estudo de interferentes é muito corriqueiro na potenciometria, sendo que a determinação do coeficiente de seletividade potenciométrico $\left(\mathrm{K}_{A, B}^{P O T}\right)$ pode ser realizada de maneiras distintas mediante a realização do método de interferência fixa, o das soluções separadas, ou ainda o do potencial equivalente. Nos método de interferência fixa e das soluções separadas obtém-se o coeficiente a partir da Equação 3.5 (UMEZAWA; UMEZAWA; SAT0, 1995):

$$
\log K_{A, B}^{P O T}=\frac{E_{2}-E_{1}}{2,303 \cdot \frac{R T}{z_{A} F}+\left(1-\frac{z_{A}}{z_{B}}\right) \log a_{A}}
$$


$\mathrm{K}_{A, B}^{P O T}$ : potencial de seletividade, $\mathrm{E}_{1}(\mathrm{~V})$ : potencial medido da espécie $\mathrm{A}$ e $\mathrm{E}_{2}(\mathrm{~V})$ : potencial da espécie interferente (B), R: constante dos gases $\left(8,31451 \mathrm{~J}^{-1}{ }^{-1} \cdot \mathrm{mol}^{-1}\right)$, T: temperatura absoluta $(\mathrm{K}), \mathrm{F}$ : constante de Faraday $\left(9,6485.10^{4}\right.$ C.mol $\left.{ }^{-1}\right), \mathrm{z}_{\mathrm{A}}$ e $\mathrm{z}_{\mathrm{B}}$ : cargas das espécies A e B e $\mathrm{a}_{\mathrm{A}}$ : atividade de A. Quando um eletrodo é seletivo à espécie $\mathrm{A}$ em relação à $\mathrm{B}$, o valor de $\mathrm{K}_{A, B}^{P O T}$ deve ser menor que a unidade.

\subsection{3- Voltametria}

Os métodos eletroanalíticos que dependem da medida de corrente, em função de potencial aplicado, são chamados métodos voltamétricos (SKOOG; WEST; HOLLER; CROUCH, 2005).

A voltametria desenvolveu-se a partir da polarografia, que é um tipo particular de voltametria que foi descoberto pelo químico Jaroslav Heyrovsky no início dos anos 1920 (1922 apud SKOOG; HOLLER; NIEMAN, 2005). Esta difere dos outros tipos de voltametria porque nesta o sensor tem a forma de um eletrodo gotejante de mercúrio (EGM).

A polarografia foi uma ferramenta muito usada pelos químicos para determinação de íons inorgânicos e de certas espécies orgânicas em soluções aquosas. Contudo, no fim dos anos 1950 e início dos anos 1960, grande parte dessas aplicações foi substituída por métodos espectroscópicos e o emprego da voltametria ficou voltado somente à determinação de oxigênio molecular em soluções.

O ressurgimento da voltametria se deu em meados dos anos 1960, quando foram desenvolvidas algumas modificações importantes nas técnicas voltamétricas, as quais resultaram no aumento significante da sensibilidade e seletividade do método. Com isso, houve o reaparecimento do interesse em aplicações de tais métodos na determinação de várias espécies, particularmente aquelas relacionadas ao meio ambiente, à indústria farmacêutica e aos processos biológicos. A voltametria moderna também continua sendo uma potente ferramenta utilizada por químicos, engenheiros e bioquímicos no estudo de processos de oxidação e redução, assim como em processos de adsorção (SKOOG; HOLLER; NIEMAN, 2005).

Diversos sensores amperométricos, ou sensores voltamétricos para potenciais fixos, são fabricados comercialmente para a determinação de espécies químicas no âmbito industrial e de pesquisa.

Tipicamente, os sensores amperométricos são compostos por três eletrodos: um eletrodo de trabalho, um de referência e um contra-eletrodo. O funcionamento deste baseia-se na medida da corrente limite sob um potencial aplicado constante e na relação da corrente com a concentração do 
analito. A razão pela qual mensura-se a corrente limite é a de que a mesma é limitada pela velocidade na qual o reagente é conduzido à superfície do eletrodo por processos de transporte de massa; assim, a corrente limite é em geral diretamente proporcional à concentração do analito (SKOOG; WEST; HOLLER; CROUCH, 2005). Tal relação pode ser descrita de forma geral pela Equação 3.6:

$$
\mathrm{I}=4 \cdot n \cdot F \cdot D_{0} \cdot C \cdot r
$$

onde I (A) é a corrente, F (9, 6485. $\left.10^{4} \mathrm{C} \cdot \mathrm{mol}^{-1}\right)$ a constante de Faraday, n é o número de elétrons transferido na reação, $\mathrm{D}_{0}\left(\mathrm{~cm}^{2} . \mathrm{s}^{-1}\right)$ é o coeficiente de difusão da espécie, $\mathrm{C}\left(\mathrm{mmol} \cdot \mathrm{L}^{-1}\right)$ é a concentração molar da solução e r o raio do eletrodo $(\mathrm{cm})$.

Uma vez que, mediante o uso dos dispositivos em questão, o potencial é mantido constante durante a medição da corrente, deve-se ressaltar a importância da avaliação da seletividade da determinação, já que a existência de espécies químicas eletroativas no potencial escolhido é comum em amostras complexas (BERTOTTI; LOWINSOHN, 2006).

Existem algumas formas de superar os problemas relacionados à seletividade desses sensores. Uma delas consiste na modificação da superfície eletródica. Tal alteração é feita visando-se à obtenção de superfícies seletivamente reativas, as quais proporcionam resultados favoráveis devido à melhoria da atividade química (MURRAY, 1980). O uso de membranas poliméricas insolúveis em meio aquoso, que são seletivas à difusão de espécies dissolvidas em solução por diferentes mecanismos, também é outro procedimento adotado que aumenta a seletividade dos sensores amperométricos. Como exemplo de substâncias convencionalmente empregadas como membranas podem ser citadas as seguintes: Nafion, policloreto de vinila (PVC), polipirrol, polianilina e acetato de celulose (FUNGARO; BRETT, 2000; BROWN; LOWRY, 2003). O modo de atuação das membranas protetoras baseia-se essencialmente na restrição de carga e de tamanho das possíveis espécies interferentes dissolvidas na amostra a ser analisada.

\section{2- Microssensores}

Embora a construção de eletrodos de dimensões micrométricas tenha se originado na década dos anos 1940, ainda há espaço para o desenvolvimento de numerosos avanços na miniaturização de sistemas eletroquímicos, pois as demandas para o incremento de métodos analíticos para o monitoramento de espécies químicas em micro-ambientes continuam em ascendência.

Segundo Skoog e colaboradores (2002): "uma das razões do interesse inicial em microeletrodos foi o desejo de estudar o processo químico que acontece dentro de organismos de espécies vivas, como nos cérebros de mamíferos". Uma das conseqüências desses estudos foi à percepção de que os 
microssensores apresentam inúmeras vantagens que justificam o seu emprego em outros tipos de problemas analíticos.

Nesse contexto, os microssensores eletroquímicos amperométricos e potenciométricos se tratam de apenas um ramo inserido em um espaço amostral imenso de sensores miniaturizados. A maior parte dos microssensores amperométricos e potenciométricos possui como compartimento externo uma micropipeta de Pasteur com ponta sensível contendo dimensões de cerca de $20 \mu \mathrm{m}$. Esses dois grupos de microssensores apresentam características distintas concernentes aos seus funcionamentos e às suas composições, devido ao fato de que os mesmos são baseados em métodos eletroanalíticos diferentes.

Tratando-se dos microssensores amperométricos, podem ser citadas algumas vantagens relativas ao tamanho dos mesmos. Dentre essas, está a queda ôhmica (iR, sendo i a corrente e R a resistência) drasticamente reduzida, graças à pequena corrente de eletrólise que flui na célula eletroquímica. Em segundo lugar, as correntes de cargas capacitivas que limitam a detecção de sensores comuns são reduzidas a proporções insignificantes à medida que o tamanho do eletrodo diminui. Terceiro, a velocidade de transporte de massa para e do eletrodo aumenta conforme o tamanho do eletrodo diminui. Com isso, correntes estacionárias são obtidas em soluções sem agitação em menos de um microssegundo. Ademais, suas dimensões micrométricas resultam na geração de correntes tão pequenas (no intervalo de picoampères e nanoampères) que em muitos casos não há a necessidade de se empregar um sistema com três eletrodos como nos sistemas voltamétricos convencionais, pois apenas dois eletrodos já bastam.

Quanto às vantagens da redução do tamanho dos sensores potenciométricos do tipo íon seletivo, chamados de ISEs miniaturizados, encontram-se o tempo de resposta reduzido, a sua simplicidade de construção aliada ao baixo custo e a sua elevada sensibilidade.

Perante as inúmeras vantagens que os microssensores apresentam, quando comparados aos macrossensores, as quais estão geralmente relacionadas diretamente com as dimensões reduzidas das pontas sensíveis dos mesmos, esses são constantemente aplicados em diversos tipos de microambientes distintos, como: biofilmes e agregados microbianos, sedimentos, plantas, flocos de neve, alimentos, superfícies dentárias, entre outros. A análise desses micros sistemas efetuada mediante a aplicação de microssensores não causa danos às estruturas dos mesmos.

\subsection{1- Microssensores para detecção de Oxigênio Dissolvido (OD)}

A quantificação do oxigênio dissolvido em meio líquido possui ampla aplicação nas áreas da medicina, biologia, ambiental, oceanografia, entre outras. Análises de oxigênio dissolvido são 
rotineiramente empregadas na indústria alimentícia, na agricultura, em estações de tratamento de esgoto e como ferramenta clínica para análise de sangue (ATKINSON et al., 1999).

Especificamente, na Engenharia Ambiental, o oxigênio dissolvido consiste em um dos principais parâmetros utilizados no controle operacional das estações de tratamento de águas residuárias e da qualidade de água de rios, lagos, etc. O conhecimento da variável em questão também é fundamental na obtenção de parâmetros cinéticos para o projeto de reatores aeróbios e controle operacional dos mesmos, bem como na avaliação da toxicidade de águas residuárias industriais e na caracterização de corpos d'água.

O motivo pelo qual a determinação de oxigênio dissolvido se faz vital em um campo tão extenso e interdisciplinar, conforme descrito antes é o de que o mesmo se trata de molécula chave na natureza. O oxigênio é produzido na fotossíntese, e é também o aceptor final de elétron na degradação da matéria orgânica. A disponibilidade de moléculas de oxigênio caracteriza-se como pré-requisito para a existência da fauna e da flora e para a ocorrência de processos microbianos aeróbios.

Métodos distintos para determinação de oxigênio dissolvido foram desenvolvidos até os tempos atuais, como: método manométrico, métodos químicos, ópticos e eletroquímicos.

Os métodos óticos são bastante empregados na quantificação de oxigênio dissolvido. Após a revelação da fibra óptica, novos tipos de sensores de OD chamados de "optrodos de oxigênio" foram desenvolvidos (TRIQUES, 1996).

As análises de oxigênio dissolvido mediante a aplicação de métodos eletroquímicos são ponderadas como as mais rápidas e de simples execução, fazendo com que as mesmas sejam as mais utilizadas, tanto em laboratório quanto em campo.

Atualmente, o método eletroquímico de determinação de oxigênio dissolvido que é comumente empregado é o baseado no sensor de OD desenvolvido por Leland Clark (1954). Tal sensor foi o primeiro a ser recoberto por uma membrana não condutiva de polietileno, sendo que atrás da mesma encontram-se situados o anodo e o catodo. Desde a publicação deste sensor, o qual fícou conhecido como sensor de OD do Tipo Clark, inúmeros sensores para análise de OD foram construídos tomando este dispositivo como modelo.

Em meados da década de 1960, diante das limitações dos sensores convencionais de OD, como instabilidade do sinal, tempo de resposta elevado e baixa seletividade, a comunidade científica começou a se interessar pela construção de microssensores de OD. Assim, os primeiros microssensores de OD construídos consistiam apenas em uma barra de platina com um bulbo de ouro em sua ponta a qual era protegida por membrana feita de resina DPX (baseada em xileno). Entretanto a simplicidade de 
construção dos mesmos não se mostrou proporcional aos seus desempenhos (WHALEN; RILEY; NAIR, 1967; BUNGAY, 1969; BAUMGARTL; LUBBERS, 1973). Uma década depois, Revsbech e Ward $^{8}$ (1983 apud GLUD; GUNDERSEN; RAMSING, 2000) obtiveram êxito na construção de microssensores de OD mediante a miniaturização do sensor de OD do Tipo Clark.

Devido ao fato de os microeletrodos em questão se tratarem de sensores de OD do Tipo Clark miniaturizados, os primeiros contém o mesmo princípio de medida dos segundos, que é o seguinte: quando um potencial elétrico suficientemente negativo é aplicado em um metal nobre que atua como catodo, feito normalmente de platina, ouro ou prata, em relação ao eletrodo de referência $(\mathrm{Ag} / \mathrm{AgCl}), \mathrm{o}$ oxigênio é reduzido na superfície do catodo. O registro da corrente fluindo entre os eletrodos em função do potencial aplicado é então determinado através da taxa de dois processos: a taxa de transporte de oxigênio do meio líquido para a superfície do catodo e a taxa total de redução catódica do oxigênio (FERREIRA, 2007).

A trajetória do transporte do oxigênio em sensores recobertos por membranas ocorre conforme ilustrado na Figura 3.5.

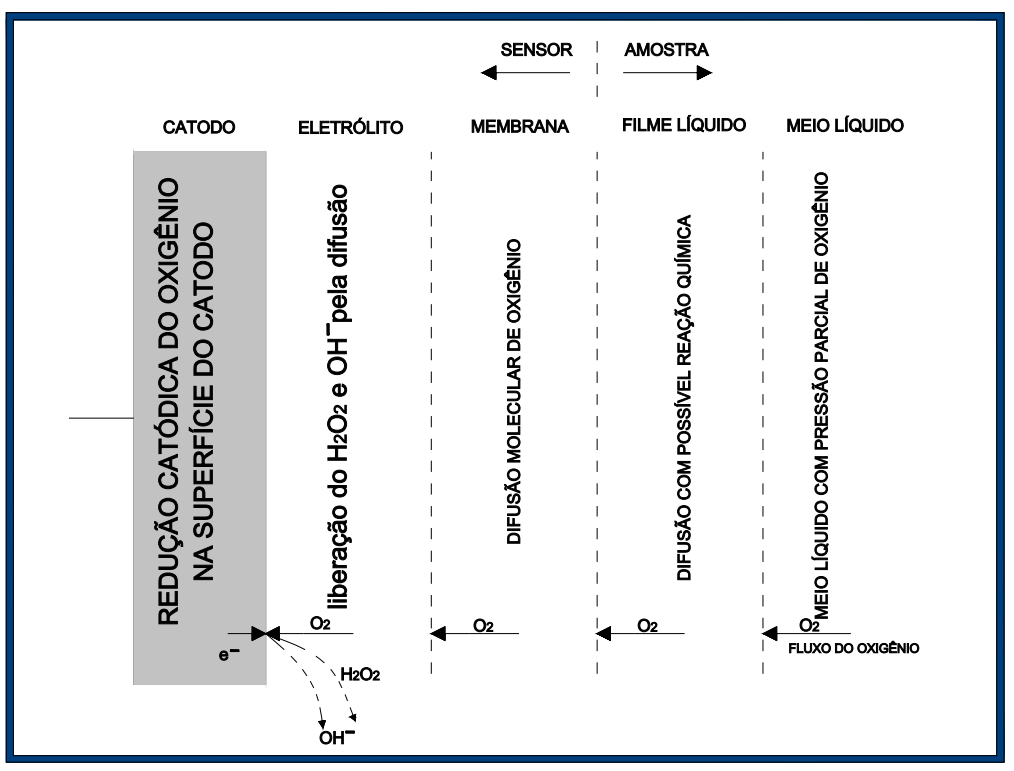

Figura 3. 5: Camadas de transporte do oxigênio até a superfície do catodo (Fonte: Adaptado de FERREIRA, 2007).

A redução do oxigênio dissolvido na superfície do catodo, seja este de prata, platina ou ouro tem dois caminhos possíveis. $\mathrm{O}$ primeiro acontece em dois passos, no qual o peróxido de hidrogênio $\left(\mathrm{H}_{2} \mathrm{O}_{2}\right)$ é a espécie intermediária (Equação 3.7)

\footnotetext{
${ }^{8}$ REVSBECH, N.P.; WARD, D. (1983). Oxygen microelectrode that is insensitive to medium chemical composition: Use in an acid microbial mat dominated by Cyanidium caldarium. Appl. Environ. Microbiol., v.45, p. 755.
} 


$$
\begin{gathered}
\mathrm{O}_{2}+2 \mathrm{e}^{-}+2 \mathrm{H}_{2} \mathrm{O} \rightarrow \mathrm{H}_{2} \mathrm{O}_{2}+2 \mathrm{OH}^{-} \\
\mathrm{H}_{2} \mathrm{O}_{2}+2 \mathrm{e}^{-} \rightarrow 2 \mathrm{OH}^{-}
\end{gathered}
$$

Já o segundo se dá em uma só etapa, a qual representa a reação total no catodo

$$
\mathrm{O}_{2}+4 \mathrm{e}^{-}+2 \mathrm{H}_{2} \mathrm{O} \rightarrow 4 \mathrm{OH}^{-}
$$

A reação no anodo de referência encontra-se na Equação 3.9,

$$
\mathrm{Ag}+\mathrm{Cl}^{-} \rightarrow \mathrm{AgCl}+\mathrm{e}^{-}
$$

É importante salientar que a taxa da reação de redução do oxigênio no catodo é promovida pela aplicação do potencial negativo no mesmo, sendo que esta taxa atinge um patamar no qual a mesma supera a taxa de transporte do oxigênio até o eletrodo, e então todo o oxigênio do meio é consumido. Neste ponto, se diz que o sensor está atuando na região da corrente limitada pela difusão (RCLD) do oxigênio, ou seja, a corrente é proporcional à concentração do oxigênio dissolvido na amostra que está sendo analisada (HITCHMAN, 1983).

Em geral, os microssensores de OD do Tipo Clark apresentam um tempo de resposta reduzido $(<1 \mathrm{~s})$, baixos valores de correntes residuais (6 pA) e baixo efeito de agitação (2\%) (LU; YU, 2002). Tais características aliadas as suas dimensões reduzidas fazem com que esses dispositivos sejam amplamente utilizados como ferramenta de pesquisa na ciência médica, limnologia e na ecologia microbiana. Ademais, a introdução dos mesmos na engenharia ambiental proporcionou avanços consideráveis nas pesquisas relacionadas aos biofilmes.

\subsection{2- Microssensores de $\mathrm{pH}$}

$\mathrm{O}$ potencial hidrogeniônico $(\mathrm{pH})$, representa a concentração de íons $\mathrm{H}^{+}$através da indicação sobre a condição de acidez, neutralidade ou alcalinidade da água.

Em termos de tratamento e abastecimento público de água, diferentes valores de pH estão associados a faixas distintas de atuação ótima de coagulantes. A quantidade de íons $\mathrm{H}^{+}$no meio comumente afeta as taxas de crescimento de microrganismos responsáveis pelo tratamento biológico de águas residuárias e nos meios aquáticos naturais.

$\mathrm{O}$ conhecimento do $\mathrm{pH}$ é fundamental tanto no tratamento de água e esgotos como também em corpos d'águas.

Para determinação da concentração de íons $\mathrm{H}^{+}$utiliza-se de forma usual macroeletrodos de $\mathrm{pH}$. Com o intuito de aplicar eletrodos de $\mathrm{pH}$ em pesquisas fisiológicas, microeletrodos de $\mathrm{pH}$ feitos a partir 
de platina foram desenvolvidos por Taylor e Whitaker ${ }^{9}$ (1927 apud CAI; REIMERS, 2000). Na década de 60, Kosyuk e Sorokina ${ }^{10}$ (1961 apud CAI; REIMERS, 2000) desenvolveram microeletrodos de $\mathrm{pH}$ com membranas de vidro e vinte anos depois microssensores de $\mathrm{pH}$ com membranas líquidas tornaramse disponíveis por Ammann et al. (1981).

Em 1983, tais microeletrodos de pH passaram a ser aplicados na caracterização de biofilmes (REVSBECH; JORGENSEN; BLACKBURN, 1983; DE BEER et al., 1997; REVSBECH, 1994), sedimentos (ARCHER; EMERSON; REIMERS, 1983; REIMERS et al., 1997) e de microambientes de organismos planctônicos (ALLDREDGE; COHEN, 1987; JORGENSEN et al., 1985). O emprego dos mesmos nos referidos meios persiste e evolui até hoje.

Atualmente, os três microeletrodos potenciométricos de $\mathrm{pH}$ mais utilizados são os feitos com membrana solidificada de troca iônica líquida (LIX-Liquid Ion Exchanger) (THOMAS, 1978), aqueles fabricados com membranas de vidro íon-sensitiva (PUCACCO et al., 1986; JORGENSEN; REVSBECH, 1988), e os produzidos a partir de metais em sua forma oxidada (VANHOUDT et al., 1992), representados na Figura 3.6.

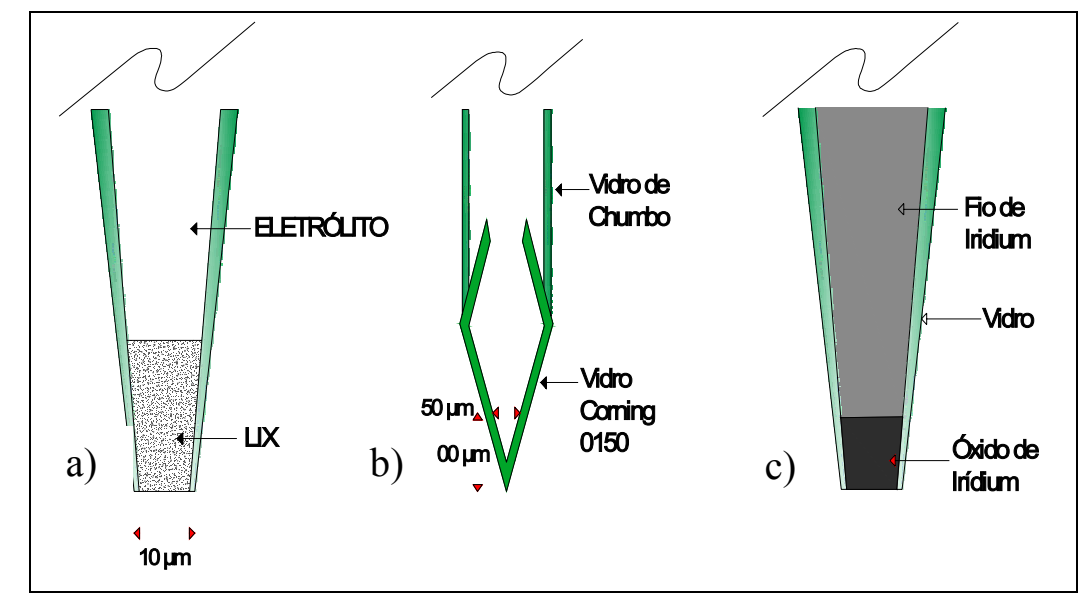

Figura 3. 6: Ilustrações dos microssensores de pH: (a) membrana de troca íon líquida, (b) membrana de vidro íon sensitiva e (c) de metais em sua forma oxidada. (Fonte: Modificada de LEWANDOWSKI; BEYENAL, 2003).

Os primeiros, baseados em membranas de troca iônica líquida, possuem modos de construção simplificados quando comparados aos dos demais, e, além disso, os mesmos são amplamente aplicados em estudos de biofilmes (AMMANN, 1986). Já os microeletrodos de membrana de vidro, requerem vasta experiência para sua fabricação, e ademais a sua popularidade em sondar biofilmes é bastante

\footnotetext{
9 TAYLOR, C.V.; WHITAKER, D.M. (1927). Potential determination in the protoplasm and cell-sap of Ntella. Protoplasma, v.3, p.1.

${ }^{10}$ KOSYUK, P.G.; SOROKINA, Z.A. (1961). On the mechanism of hydrogen ion distribution between cell protoplasm and the medium. Membrane Transport Metabolism. New York, p.3.
} 
restrita pelo fato de que a sua ponta, responsável pelo contato de leitura, é relativamente extensa e conduz medições de pH inexatas e não pontuais.

Os microeletrodos baseados em óxidos de metais nobres não exigem complexidade para sua construção já que a principal dificuldade está em oxidar o metal nobre. Os óxidos de alguns metais nobres são sensíveis à concentração hidrogeniônica do meio e essa característica faz com que esses possam ser usados como microeletrodos de $\mathrm{pH}$, entretanto não existem registros da utilização desses em filmes microbianos.

\subsection{3- Microssensores para mensuração de íons nitrato $\left(\mathrm{NO}_{3}{ }^{-}\right)$, nitrito $\left(\mathrm{NO}_{2}{ }^{-}\right)$e amônio $\left(\mathrm{NH}_{4}{ }^{+}\right)$}

Nos ciclos do nitrogênio no meio aquático, o nitrogênio pode ser encontrado nas seguintes formas: nitrogênio molecular $\left(\mathrm{N}_{2}\right)$, o qual escapa para a atmosfera, nitrogênio orgânico (dissolvido e em suspensão), amônia na forma livre $\left(\mathrm{NH}_{3}\right)$ e ionizada $\left(\mathrm{NH}_{4}{ }^{+}\right)$, íons nitrato $\left(\mathrm{NO}_{3}{ }^{-}\right)$e nitrito $\left(\mathrm{NO}_{2}{ }^{-}\right)$.

Tais espécies podem ser determinadas pelo método de Kjeldahl, por análise de injeção em fluxo (FIA), por métodos espectrofotométricos, titrimétricos e outros (FERREIRA et al., 2004). Todavia, tem-se que para análise de tais espécies químicas em biofilmes os métodos citados anteriormente não podem ser empregados, já que os mesmos não se tratam de técnicas realizadas in situ.

Microssensores de detecção de íons nitrato $\left(\mathrm{NO}_{3}^{-}\right)$, nitrito $\left(\mathrm{NO}_{2}{ }^{-}\right)$, amônio $\left(\mathrm{NH}_{4}{ }^{+}\right)$e de óxido nitroso $\left(\mathrm{N}_{2} \mathrm{O}\right)$ foram desenvolvidos por Revsbech (1989) visando o emprego dos mesmos na verificação da ocorrência de processos de nitrificação e desnitrificação em biofilmes.

Com base nos microssensores de Revsbech, outros diversos tipos de microletrodos para mensuração dessas mesmas espécies em biofilmes e sedimentos foram criados (LARSEN et .al., 1996; DE BEER et al., 1997; BUHLMANN et al., 1998; BOLLMANN; REVSBECH, 2005), dentre os quais se encontram microbiossensores que possuem enzimas imobilizadas em sua membrana, microssensores amperométricos e potenciométricos do tipo íon seletivos.

\subsection{4- Microssensores para detecção de $\mathrm{H}_{2} \mathrm{~S}$}

Sulfetos consistem em componentes importantes em meios aquáticos. Em soluções aquosas os sulfetos podem ser encontrados na forma de gás sulfídrico dissolvido $\left(\mathrm{H}_{2} \mathrm{~S}\right)$, íons bissulfeto (HS $)$ e íons sulfeto $\left(\mathrm{S}^{2-}\right)$, dependendo do $\mathrm{pH}$ do meio e da temperatura.

A elevada toxicidade do gás sulfeto de hidrogênio para a maior parte dos organismos, fez com que diversas alternativas para a remoção do mesmo de efluentes gasosos fossem desenvolvidas. Processos físico-químicos como adsorção, absorção e incineração têm sido utilizados com tal 
finalidade. Contudo, as disposições desses processos são onerosas e nesses ocorre comumente à geração de poluentes secundários (MA; ZHAO; YANG, 2006). Diante disso, a biorremoção de sulfetos é considerada como alternativa interessante, já que diversos microrganismos são capazes de biodegradar o $\mathrm{H}_{2} \mathrm{~S}$ em reatores biológicos.

Vários organismos quimiotróficos são capazes de biodegradar o gás sulfeto de hidrogênio no interior de reatores biológicos, tais como: Xhantomonas sp., Pseudomonas sp., Thiobacillus sp., Acidithiobacillus sp. Esses organismos são capazes de crescer e de produzir novo material celular através da utilização de $\mathrm{CO}_{2}$ inorgânico como fonte de carbono e de energia química a partir da oxidação de compostos inorgânicos reduzidos, como o $\mathrm{H}_{2} \mathrm{~S}$ (FILHO, 2008).

Investigações desses processos e de inúmeros outros associados às espécies de enxofre que não foram aqui descritos, requerem sistemas analíticos com baixos limites de detecção e tempos de resposta reduzidos. Extensa variedade de técnicas pode ser empregada para medição de concentrações de sulfeto total, íons sulfeto e sulfeto de hidrogênio dissolvido. As mais importantes e, consequentemente, mais utilizadas são a técnica do azul de metileno, a iodometria, a espectrofotometria e a colorimetria. Contudo, a maior parte dessas técnicas é executada, através de análises ex situ, ou seja, a realização de amostragens é necessária (KUHL; STEUCKART, 2000).

Métodos de determinação eletroquímica de espécies de enxofre apresentam a vantagem de poderem ser feitas em quaisquer ambientes, inclusive em microambientes, como é o caso dos biofilmes. Existem diversos tipos sensores potenciométricos e amperométricos que podem ser aplicados para tal determinação (Tabela 3.2).

Tabela 3. 2: Tipos de sensores utilizados na determinação de concentrações das espécies de enxofre.

\begin{tabular}{|c|c|c|}
\hline Método & Tipo de Sensor & Referência \\
\hline Potenciometria & ISE de $\mathrm{Ag} / \mathrm{Ag}_{2} \mathrm{~S}$ & בBERNER, 1963 \\
\hline Potenciometria & ISE (membrana LIX) & TSE et al., 1995 \\
\hline Pontenciometria & ISE (pasta de carbono) & HU; LENG, 1996 \\
\hline Amperometria & $\begin{array}{c}\text { Biossensor(Thiobacillus thiooxidans } \\
\text { imobilizada) }\end{array}$ & KUROSAWA et al., 1994 \\
\hline Amperometria & Mediador redox & JEROSCHEWSKI et al., 1993 \\
\hline Amperometria & Microssensor de $\mathrm{H}_{2} \mathrm{~S}$ & JEROSCHEWSKI et al., 1996 \\
\hline
\end{tabular}

Tomando-se como base o princípio de detecção amperométrica para determinação de sulfeto de hidrogênio dissolvido em meio aquáticos, desvendado por Jeroschewski e colaboradores (1988), vários macro sensores para detecção de $\mathrm{H}_{2} \mathrm{~S}$ foram desenvolvidos. Posteriormente, tais macros sensores foram 
miniaturizados para monitoramento de fenômenos relacionados ao ciclo do enxofre que se dão no interior de biofilmes e sedimentos (KUHL et al., 1998; JEROSCHEWSKI et al.,1996;).

O princípio de detecção amperométrica desses microssensores pode ser explicado da seguinte maneira: primeiramente o gás $\mathrm{H}_{2} \mathrm{~S}$ se difunde através da membrana para o interior dos microssensores onde o mesmo se dissolve no eletrólito do microssensor (Equação 3.10); depois o $\mathrm{H}_{2} \mathrm{~S}$ aquoso dissociase em íons bissulfeto (HS-) e em íons $\mathrm{H}^{+}$(Equação 3.11). Os íons bissulfeto são oxidados pelo mediador redox, composto que tem como função oxidar (ou reduzir) o elemento que se deseja mensurar quando a reação de oxidação (ou redução) do mesmo causa deterioração ou inativação da superfície eletródica, presente na forma de ferricianeto $\left(\left[\mathrm{Fe}(\mathrm{CN})_{6}\right]^{3-}\right)$ na solução eletrolítica do microssensor (Equação 3.12). O ferricianeto $\left(\left[\mathrm{Fe}(\mathrm{CN})_{6}\right]^{3-}\right)$ reduzido na reação de oxidação do íons $\mathrm{HS}^{-}$é então reoxidado na superfície do eletrodo de platina (Equação 3.13), e essa reação produz corrente proporcional a concentração de gás sulfídrico presente no lado externo da membrana do microssensor (Figura 3.7) (KUHL et al., 1998; JEROSCHEWSKI et al.,1996).

$$
\begin{aligned}
& \mathrm{H}_{2} \mathrm{~S}(\mathrm{~g}) \gtrless \mathrm{H}_{2} \mathrm{~S}(\mathrm{aq}) \\
& \mathrm{H}_{2} \mathrm{~S}(\mathrm{aq}) \gtrless \mathrm{HS}^{-}(\mathrm{aq})+\mathrm{H}^{+}(\mathrm{aq}) \\
& \mathrm{HS}^{-}(\mathrm{aq})+2\left[\mathrm{Fe}(\mathrm{CN})_{6}\right]^{3-}(\mathrm{aq}) \gtrless 2\left[\mathrm{Fe}(\mathrm{CN})_{6}\right]^{4-}(\mathrm{aq})+\mathrm{S}_{0}+\mathrm{H}^{+}(\mathrm{aq}) \\
& 2\left[\mathrm{Fe}(\mathrm{CN})_{6}\right]^{4-}(\mathrm{aq}) \gtreqless 2\left[\mathrm{Fe}(\mathrm{CN})_{6}\right]^{3-}(\mathrm{aq})+2 \mathrm{e}^{-}
\end{aligned}
$$

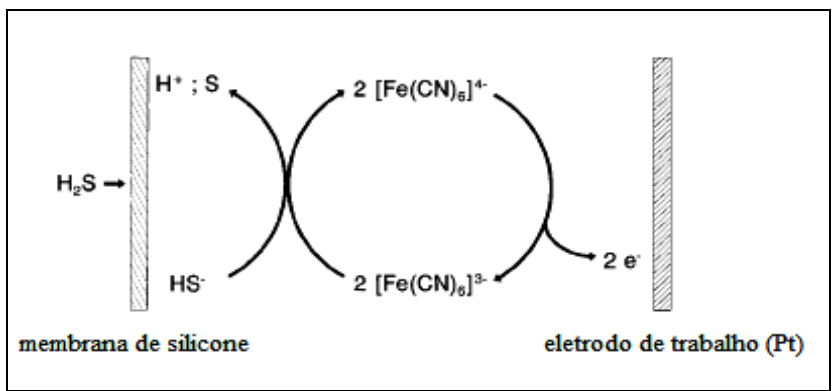

Figura 3. 7: Esquema ilustrativo das reações ocorridas na deteç̧ão amperométrica de $\mathrm{H}_{2} \mathrm{~S}$ (Fonte: KUHL; JEROSCHEWSKI; STEUCKART, 1996).

\section{3- Biofilmes}

Existem diversas definições para biofilme entre as quais uma das mais conceituadas foi proposta por Xavier et al. (2002), em que "biofilme, é uma comunidade de microrganismos imobilizados, conjuntamente, em uma matriz de substâncias poliméricas extracelulares de origem microbiana”. Esta definição inclui os agregados e flocos microbianos e também populações que possam se aderir no interior de espaços porosos. 


\subsection{1- Desenvolvimento do biofilme}

Conforme proposto por Bryers (1988), a formação do biofilme se dá quando quaisquer superfícies são expostas a ambientes aquosos não estéreis nos quais se fazem presentes constituintes químicos diversos, adequados para o crescimento de microgarnismos.

O desenvolvimento dos biofilmes ocorre em três etapas: aderência, crescimento e remoção do biofilme. A colonização e crescimento incluem consumo de substrato, crescimento celular e replicação, manutenção do biofilme e produção de exopolímeros. A etapa de remoção do biofilme envolve processos como predação, cisalhamento, abrasão e desprendimento (BRYERS, 1988). A Figura 3.8 ilustra esquematicamente a dinâmica do desenvolvimento do biofilme.

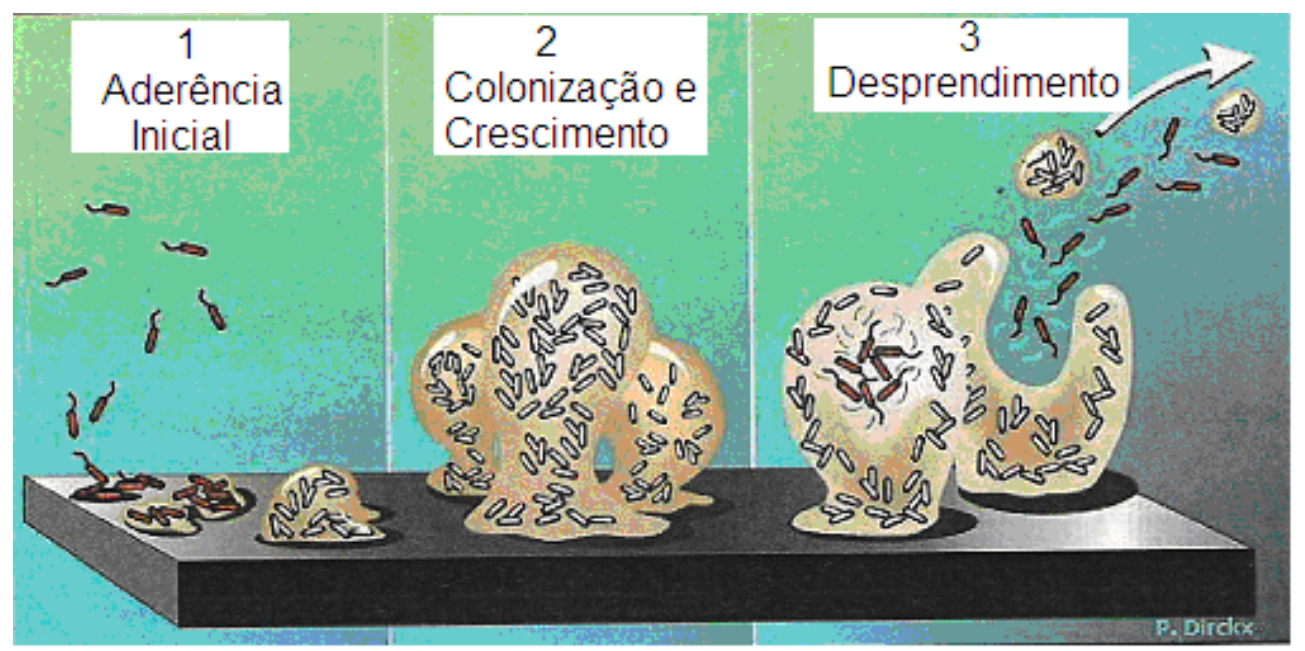

Figura 3. 8: Ilustração do desenvolvimento do biofilme (Fonte: Adaptado de STOODLEY; DIRKX, 2003).

Anteriormente à aderência inicial, o transporte das células à superfície acontece de três formas distintas: por difusão molecular, por convecção das células e por movimento ativo. A primeira relaciona-se diretamente com o movimento browniano não desprezível que os organismos possuem, o qual é responsável pelo encontro dos mesmos com a interface sólida. O transporte convectivo de células, que ocorre mais rapidamente em várias ordens de magnitude do que o anterior está associado ao fluxo de líquido do meio. Já o movimento ativo acontece quando organismos móveis, localizados nos arredores de uma superfície, a encontram ao acaso ou respondem por quimiotaxia a qualquer gradiente de concentração que possa existir na região interfacial.

A fase seguinte ao transporte de células livres do meio é a aderência inicial dos microrganismos às superfícies suportes. Essa ocorre devido às interações físico-químicas não específicas que são conduzidas pelas cargas elétricas e hidrofobicidade dos microrganismos e dos materiais envolvidos (MARSHALL, 1986). Posteriormente à aderência inicial, ocorre a aderência firme, na qual a célula 
microbiana deposita-se na superfície sólida devido às ligações fortes que se dão entre as substâncias poliméricas extracelulares e o material suporte.

A colonização da superfície consiste na última etapa da aderência microbiana. Depois que as células se fixam firmemente, o processo de duplicação é iniciado, no qual as células novas aderem-se umas as outras. Assim, se dá o desenvolvimento das microcolônias ou dos biofilmes.

Conforme citado antes, a remoção do biofilme ocorre como consequência de quatro fenômenos distintos: predação, cisalhamento, abrasão e desprendimento. Dentre esses, os processos de remoção mais estudados são os de cisalhamento e desprendimento.

A remoção por desprendimento é um evento de ocorrência periódica no qual grande quantidade, ou seções inteiras do biofilme deixam a superfície sólida e adentram o meio circundante. Tal processo está relacionado com a presença de zonas anaeróbias localizadas no interior de biofilmes aeróbios muito espessos, pois nas regiões mais profundas desses biofilmes, ocorre produção de ácidos voláteis com consequente abaixamento de $\mathrm{pH}$ e produção de gases insolúveis, fatores que enfraquecem a estrutura do biofilme levando ao desprendimento do mesmo de sua superfície suporte (ARAÚJO, 2001).

\subsection{2- Heterogeneidade dos Biofilmes}

Segundo Campos (1989), as primeiras considerações relacionadas à ocorrência de processos biológicos de natureza distinta em um mesmo biofilme começaram a surgir em meados da década dos anos 1980. Essas faziam referência à existência de bactérias aeróbias e anaeróbias; bactérias anaeróbias e anóxicas; ou bactérias aeróbias e anóxicas; ou ainda os três tipos juntos localizados no interior de um único biofilme. Wu e colaboradores (1987) confirmaram a existência de pequenas zonas anóxicas e de núcleos anaeróbios internamente aos flocos biológicos localizados em meio aeróbio, conforme esquematizado na Figura 3.9.

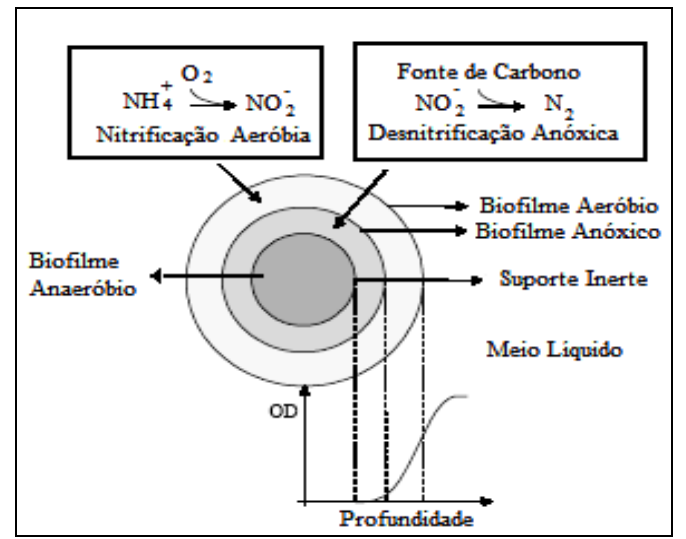

Figura 3. 9: Ilustração de biofilme com zonas distintas (Fonte: Adaptado de NEDOVIC et al., 2005). 
A partir de estudos relacionados à ocorrência de processos biológicos distintos no interior de um mesmo biofilme, Campos (1989) sugeriu algumas situações passíveis de ocorrer no interior dos filmes microbianos, exibidas na Figura 3.10.

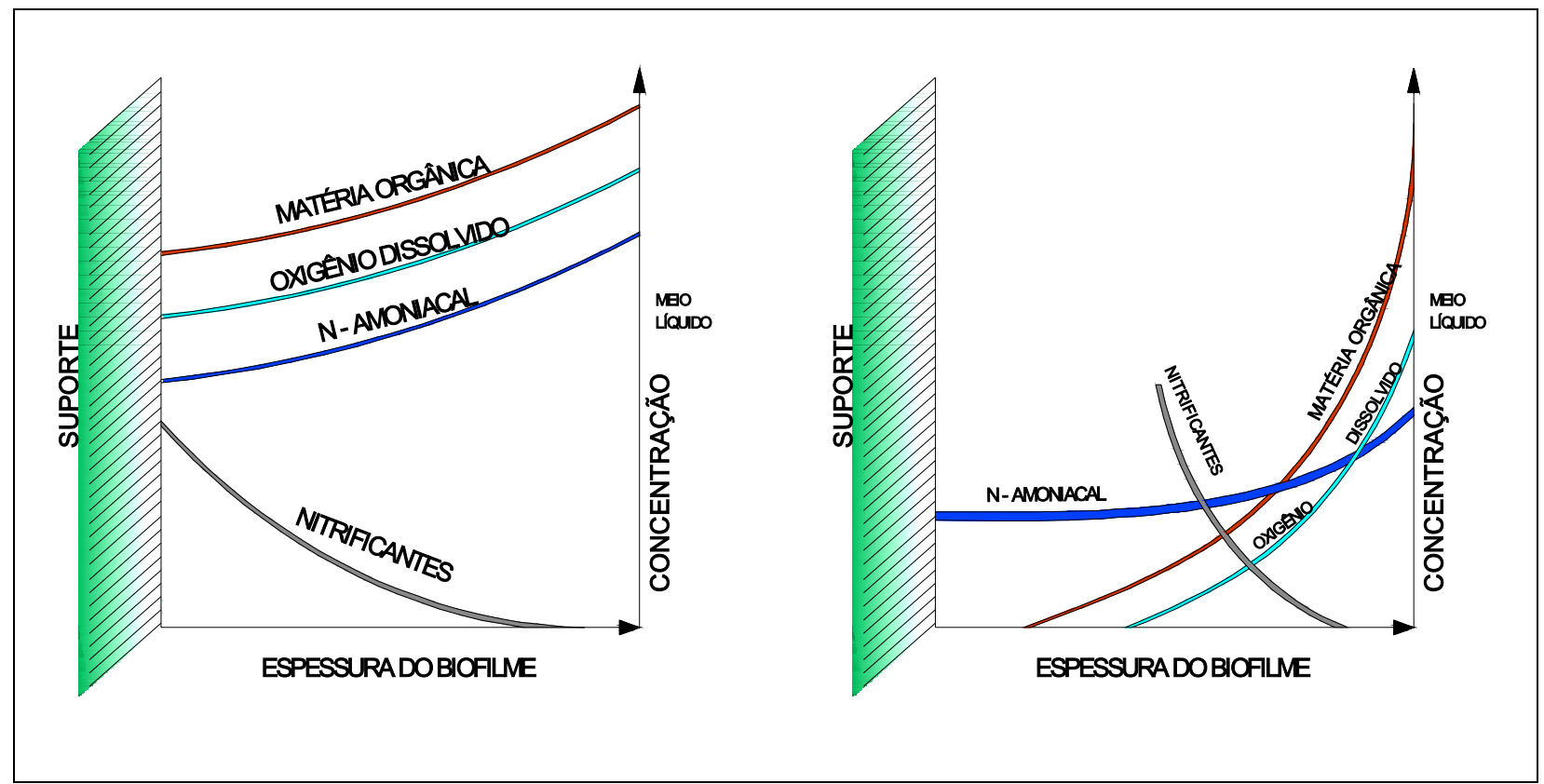

Figura 3. 10: Esquema de biofilme em que ocorre nitrificação e penetração total de $\mathrm{NH}_{3}$, matéria orgânica e OD (esquerda). Esquema de biofilme no qual ocorre penetração total de $\mathrm{NH}_{3}$ e parcial de OD e matéria orgânica (direita) (Fonte: Adaptado de CAMPOS, 1989).

Dentre os modelos conceituais criados para o estudo de biofilmes encontram-se os modelos homogêneos e os heterogêneos. No modelo homogêneo o biofilme é tratado como agregado celular aderido de forma uniforme à superfície suporte enquanto que no modelo heterogêneo acredita-se que o mesmo é formado a partir de agregados densos e porosos de micro colônias aderidos irregularmente sobre a superfície suporte inerte (DE BEER et al., 1993).

Em meio aos modelos de biofilme heterogêneo encontra-se o modelo "water-channel" traduzido como modelo do biofilme penetrado por canais (COSTERSTON et al., 1995). Esse modelo propõe que os biofilmes contêm estruturas complexas nas quais as micro colônias se arranjam em camadas e em aglomerados que possuem formatos de cones e de cogumelos entre as quais se permeiam vazios e canais que permitem o transporte de massa por processos convectivos (Figura 3.11). 


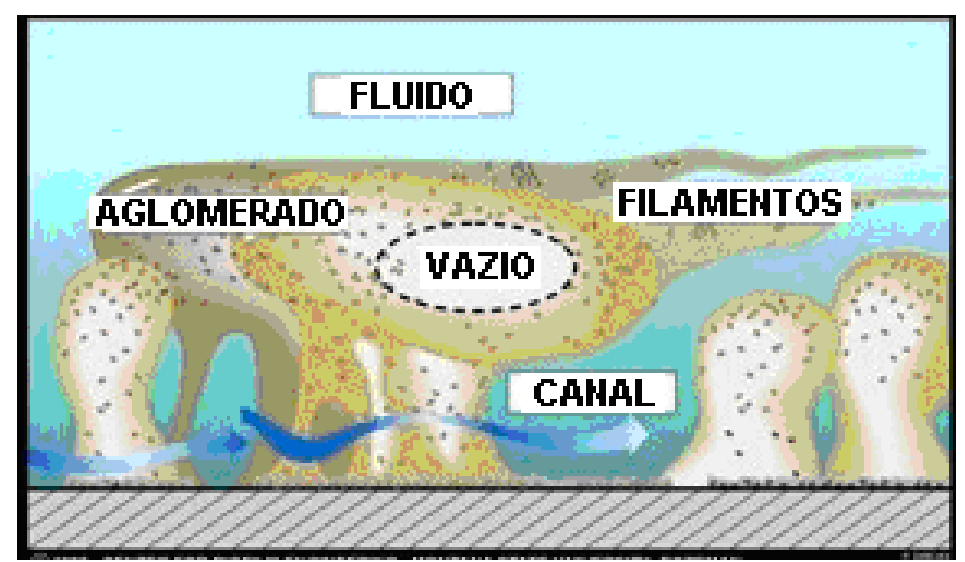

Figura 3. 11: Modelo da arquitetura de um biofilme heterogêneo (Fonte: COSTERSTON et al., 1995).

Com base em pesquisa fundamentada em observações de biofilmes vivos feitas com microscópio confocal de varredura a laser (CSLM), foi confirmada a indicação levantada inicialmente por Fletcher (1987) de que os biofilmes não possuem estruturas planas nas quais a distribuição de microrganismos e de espécies químicas não ocorre de forma uniforme (DE BEER et al., 1993). Os autores dessa pesquisa asseguraram que os biofilmes são heterogêneos por possuírem distribuição nãouniforme de diversos elementos que o constituem como a biomassa, os nutrientes, os produtos do metabolismo microbiano e os grupos de microrganismos, entre outros.

Uma vez que a heterogeneidade das estruturas dos biofilmes pôde ser visualizada através da técnica de microscopia confocal de varredura a laser (CSLM) por De Beer e colaboradores (1993), outros grupos de pesquisa recorreram à aplicação de diversas técnicas que visavam à quantificação do transporte de massa e a determinação de estruturas complexas em sistemas de biofilme heterogêneo como, por exemplo: ressonância magnética nuclear (RMN), eletrodo de varredura de vibração (SVE), sondas fluorescentes, voltametria cíclica entre inúmeras outras, sendo que dentre essas se encontram os microssensores (LEWANDOWSKI; BEYENAL, 2006).

Lewandowski e colaboradores (1995) demonstraram as heterogeneidades estruturais dos biofilmes por meio da aplicação de microssensores de oxigênio dissolvido, pois com esses a obtenção de perfis de concentrações de oxigênio totalmente distintos foi verificada de acordo com o local de introdução do microletrodo no interior de um único biofilme heterogêneo. A Figura 3.12 ilustra o descrito anteriormente. 


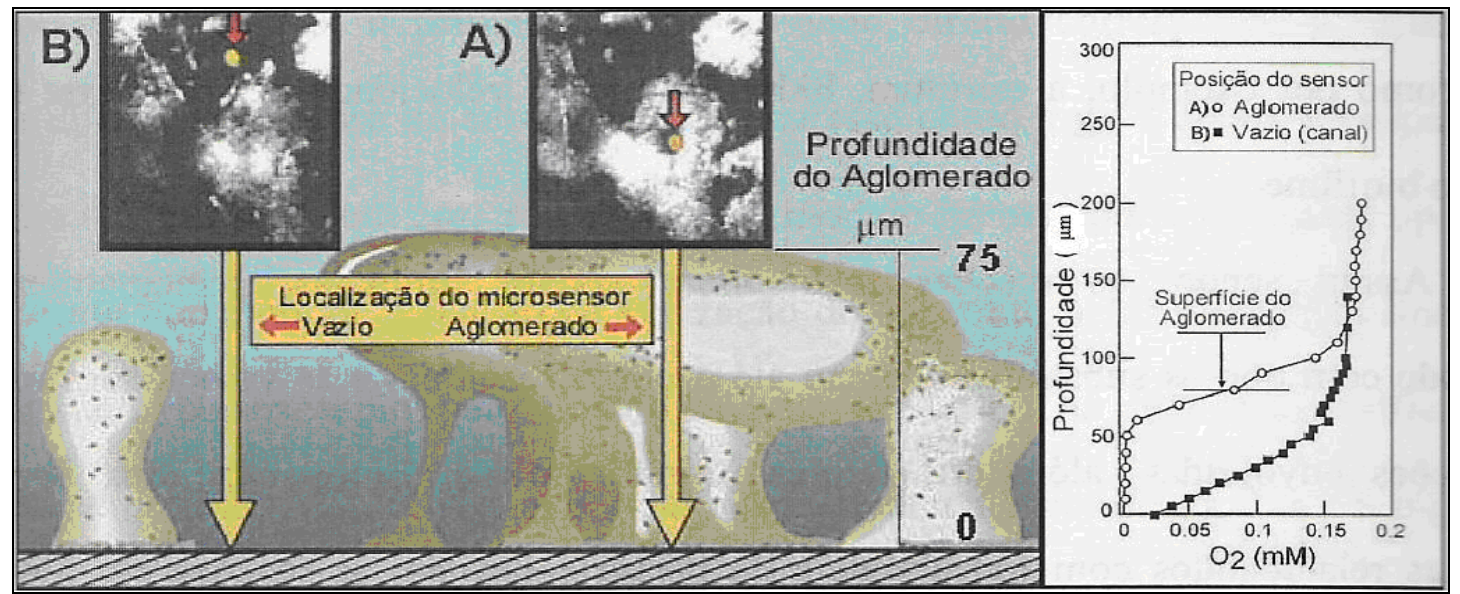

Figura 3. 12: Ilustração dos locais de introdução do microssensor em biofilme e seus respectivos perfis de [OD] (Fonte: LEWANDOWSKI et al., 1995).

Lewandowski, Walser e Characklis (1991), em pesquisa associada à influência dos fatores hidrodinâmicos em biofilmes, verificaram que inúmeros elementos influenciam a acumulação de massa celular em biofilme heterogêneos como a velocidade de crescimento celular, velocidade de utilização do substrato e concentração do mesmo, processo de endogenia e da perda por cisalhamento, decorrentes das condições hidrodinâmicas do líquido que escoa junto ao biofilme. Como consequências de tais influências diversas que atuam na espessura dos biofilmes, contradições relacionadas às dimensões das mesmas foram constatadas na bibliografia consultada sobre o assunto (ANDREWS, 1985; DE BEER et al., 1993; HANGEDORN-OLSEN et al., 1994; GEBARA; SOBRINHO; JUNIOR, 2006). Estas variaram desde cerca de $150 \mu \mathrm{m}$ a $2 \mathrm{~mm}$. Biofilmes com espessuras distintas também foram observados quando os mesmos encontraram-se aderidos a diferentes tipos de material suporte em pesquisa realizada por Lamon e colaboradores (2008).

Com relação à modelação matemática dos biofilmes, tem-se que o primeiro modelo matemático, proposto por Wanner e Gujer (1986), baseou-se em biofilme unidimensional, no qual foram considerados apenas gradientes perpendiculares ao biofilme e sua interface líquida. Esse tipo de modelo consiste em ferramenta adequada quando se deseja descrever as conversões macroscópicas que se dão em biofilmes. Contudo, tais modelos (1-D) não revelam como a estrutura de biofilmes é desenvolvida e/ou modificada pela ocorrência de gradientes laterais aos mesmos e nem como a presença de poros no interior dos biofilmes altera a ocorrência de seus processos biológicos e químicos.

Outros modelos matemáticos para biofilmes foram desenvolvidos, do mesmo modo que o primeiro, tomando-se como base biofilmes unidimensionais (CHARACKLIS; MARSHALL, 1990; WIMPENNY, 1997; PICIOREANU et al., 1998; 2000; 2001; KREFT; WIMPENNY, 1998; 2001). Nos 
modelos citados anteriormente, não foi proposto nenhum mecanismo hipotético que descrevesse as interações microbianas internas aos biofilmes.

Modelos embasados em biofilmes bidimensionais e tridimensionais foram sugeridos com o intuito de prever diferentes aspectos da heterogeneidade de biofilmes, como a formação de microcolônias, o desenvolvimento de padrões de colonização heterogêneo, a formação de aglomerados, entre outros (EBERL et al., 2001; PIZARRO; GRIFFEATH; NOGUEIRA, 2001). Todavia, nesses somente alguns componentes que compõem os biofilmes foram levados em consideração, admitindo dessa forma que os mesmos possuíam biomassa constante ao longo de suas espessuras.

Laspidou e Rittmann (2004) desenvolveram modelo matemático mediante o qual se fez possível prever quantitativamente a heterogeneidade dos biofilmes a partir de diversos componentes como biomassa ativa e inerte, polissacarídeos extracelulares, substratos solúveis e alguns produtos de reações metabólicas microbianas. Apesar de o modelo em questão ser, possivelmente, o mais completo já desenvolvido, por meio do qual se faz possível antever a estrutura de biofilmes e os processos biológicos interiores aos mesmos, o mesmo apresenta extrema complexidade matemática que limita de maneira drástica a sua aplicação.

\section{3 - Limitações da Técnica de Microperfilação in situ com Microssensores}

Como todas as técnicas analíticas, o uso de microssensores para mensuração de concentrações de variáveis diversas em biofilmes possui suas desvantagens. Essas derivam tanto de imperfeições inerentes aos microssensores quanto da complexidade das amostras a que estes estão destinados a analisar.

Tratando-se primeiro das deficiências dos microeletrodos em si podem ser enumeradas as seguintes: o tempo de vida dos microssensores e preservação da eficácia dos mesmos, já que se sabe que alterações das condições externas a eles, tais como variações de temperatura e de pressão causam mudanças em suas propriedades físicas e químicas, as quais refletem nos sinais de corrente e de potencial gerados pelos mesmos. As interferências eletromagnéticas que geram ruídos eletrônicos os quais dificultam a aquisição de medidas estáveis. A geometria reduzida de suas pontas pode repercutir no surgimento de potenciais na ponta dos microssensores; entre outras. Essas consistem em assuntos que necessitam ser mais bem investigados, para que soluções para tais falhas possam ser encontradas.

Quanto à aplicação dos microeletrodos para avaliação de biofilmes algumas barreiras que dificultam a interpretação dos dados obtidos através de seus usos recaem nos fatos de que os biofilmes possuem estruturas complexas e não-uniformes ao longo das quais diferentes processos biológicos 
ocorrem simultaneamente e a velocidade de desenvolvimento dos mesmos dificulta os seus monitoramentos mediante a aplicação de microssensores.

Beyenal e Lewandowski (2000) sugeriram que a escolha do local de introdução dos microssensores nos biofilmes visando à obtenção de microperfis de concentrações de substratos no interior dos mesmos fosse feita de forma minuciosa, de modo que os microeletrodos fossem sempre introduzidos no centro de aglomerados celulares (local supostamente dotado de estrutura homogênea); entretanto tal feito só é factível com o auxílio de instrumentos adequados para identificação dos referidos centros de aglomerados de células. 


\section{4-MATERIAL E MÉTODOS}

\section{1- Apresentação}

Esse capítulo tem como objetivo detalhar os procedimentos experimentais utilizados para alcançar os objetivos propostos nessa pesquisa. Os procedimentos experimentais podem ser divididos em quatro etapas principais: i) construção e calibração dos microssensores; ii) realização de testes dos microssensores construídos e de alguns constituintes dos mesmos; iii) operação das células de fluxo para desenvolvimento dos biofilmes; iv) aplicação dos microssensores construídos nos biofilmes aderidos nas superfícies das células de fluxo e realização de análises físico-químicas no afluente e efluente das mesmas.

A primeira etapa - construção dos microssensores - foi iniciada com o microeletrodo para detecção de oxigênio dissolvido, pois antes do começo dessa pesquisa o protocolo de construção deste já havia sido elaborado pelo técnico especializado Antônio Wagner Lamon. Como tal atividade requer muita habilidade manual, diversos microssensores de OD foram construídos a fim de se adquirir a desenvoltura necessária para construção destes e consequentemente dos outros microssensores que seriam confeccionados ao longo do presente estudo, os quais possuem protocolos semelhantes aos dos microeletrodos de OD. Depois de adquirida tal destreza, microssensores de $\mathrm{pH}$, íons nitrato, íons amônio e $\mathrm{H}_{2} \mathrm{~S}$ foram construídos e calibrados, nesta ordem.

A segunda etapa foi realizada quando o desempenho dos microssensores construídos já havia sido verificado mediante observação das curvas de calibração dos mesmos. Optou-se por fazer testes de seletividade dos microssensores potenciométricos de $\mathrm{pH}$, íons nitrato e amônio, pois foi constatado na literatura que os mesmos poderiam não ser seletivos aos seus analitos. Nessa etapa, os eletrodos de referência de $\mathrm{Ag} / \mathrm{AgCl}$ dos microssensores de $\mathrm{OD}$ foram avaliados devido ao fato de que alguns desses microssensores demonstraram perda de eficiência com o passar do tempo. Novo procedimento para obtenção dos eletrodos de trabalho foi posteriormente proposto.

A terceira e a quarta etapa foram feitas concomitantemente, visto que ao mesmo tempo em que as células de fluxo foram operadas, a aquisição de microperfis mediante o uso de microssensores e o monitoramento das condições operacionais e eficiência das mesmas, realizados por meio de análises físico-químicas também foram executados.

No período em que os cinco experimentos (que serão posteriormente detalhados) foram realizados, houve a junção da primeira etapa com a terceira e a quarta etapas, pois os microssensores foram construídos, calibrados e aplicados nos biofilmes formados sobre as superfícies suportes das 
células de fluxo que estavam sendo operadas e monitoradas mediante a execução das análises físicoquímicas.

A Figura 4.1 contém um fluxograma das etapas principais realizadas na presente pesquisa.

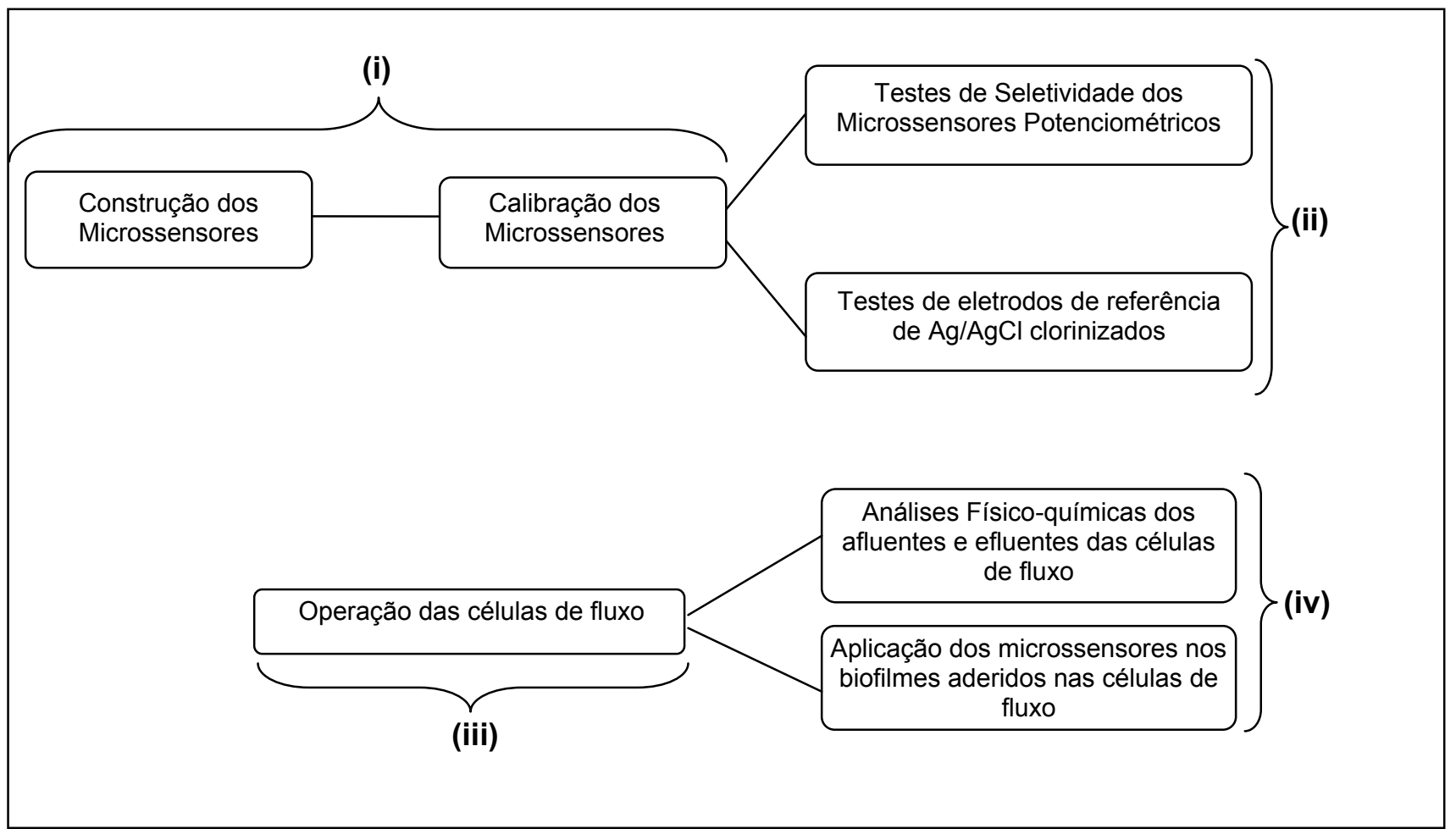

Figura 4. 1: Fluxograma das principais etapas realizadas.

\section{2- Microssensores}

\subsection{1- Laboratório de Microssensores}

A confecção dos microssensores utilizados na presente pesquisa foi realizada nas instalações do Laboratório de Microssensores (SHS-EESC). Esse laboratório foi arquitetado especificamente para construção e aplicação de microssensores em biofilmes, sendo que as atividades de seleção dos equipamentos necessários para a confecção dos microeletrodos, a montagem da sala para receber tais equipamentos e do laboratório para servir de núcleo de estudo de biofilmes com microssensores foram executadas pelo técnico especializado, Antônio Wagner Lamon.

Tal laboratório dispunha de toda aparelhagem e instrumentação necessária para que os microeletrodos pudessem ser construídos. A Tabela 4.1 discrimina os equipamentos do laboratório que foram utilizados na construção dos mesmos. 
Tabela 4. 1- Equipamentos do Laboratório de Microssensores, pertencente ao Laboratório de Microssensores (SHSEESC - USP).

\begin{tabular}{|c|c|}
\hline Quantidade & Material Permanente \\
\hline \hline 1 & Grinder para lapidação de microssensores \\
\hline 1 & Aparelho modelador para vidros \\
\hline 1 & Bancada Magnética/Capela \\
\hline 3 & Iluminadores com fibra ótica para microscópio \\
\hline 2 & Microcomputadores e componentes \\
\hline 1 & Fonte de alimentação regulável digital \\
\hline 1 & Aparelho electrometec/high-resistence \\
\hline 6 & Prendedores magnéticos para microssensores \\
\hline 6 & Micromanipuladores para microssensores \\
\hline 1 & Aparelho picoamperímetro digital com fonte \\
\hline 1 & Microscópio com câmera \\
\hline 1 & Microscópio com braço articulado \\
\hline 1 & Compressor de ar \\
\hline 1 & Deionizador \\
\hline 1 & Microscópio invertido \\
\hline 1 & Banho ultra-sônico \\
\hline 1 & Aparelho glass melter \\
\hline 1 & Servo motor para micromanipulador \\
\hline
\end{tabular}

\subsection{2- Construção e calibração do microssensor amperométrico de OD}

Os microeletrodos eletromecânicos de OD foram feitos com base nos estudos de Revsbech e Jorgensen (1986) e Revsbech (1989), entretanto o protocolo de construção deste foi modificado pelo técnico especializado Antônio Wagner Lamon, o qual eliminou o uso do eletrodo de guarda, adotado primeiramente para redução da corrente residual do sensor (LAMON et al., 2OO7).

Por serem microssensores amperométricos do Tipo Clark, estes foram constituídos de um eletrodo de referência de $\mathrm{Ag} / \mathrm{AgCl}$ (anodo), um eletrodo de trabalho de fio de platina com bulbo de ouro (catodo), membrana de silicone permeável ao oxigênio e eletrólito interno, inseridos em um compartimento externo.

O eletrodo de referência de $\mathrm{Ag} / \mathrm{AgCl}$ foi obtido com base em processo de depósito eletrolítico, o qual fez uso de uma solução eletrolítica de ácido clorídrico ( $\mathrm{HCl} 0,1 \mathrm{M})$, uma barra de grafite (Aldrich, 49654-4, 3 mm de diâmetro) e um fio de prata (diâmetro de $300 \mu \mathrm{m}$ ). Esse sistema foi conectado a uma fonte de alimentação regulável a qual foi mantida sob tensão de $0,7 \mathrm{~V}$ durante um período de 24 horas.

O eletrodo de trabalho consistiu em um fio de platina (com diâmetro de 50 ou $100 \mu \mathrm{m}$ ) que teve sua ponta afinada para diâmetros menores $(5$ a $10 \mu \mathrm{m})$ por meio de eletrólise na qual se utilizou solução 
de cianeto de potássio $(\mathrm{KCN})$ saturada. Traços de íons cianeto foram removidos do fio através de sucessivos banhos com solução de ácido sulfúrico e água destilada. Este fio foi inserido em capilar de vidro de borossilicato e na ponta do mesmo foi aplicado, via deposição eletrolítica, bulbo de ouro proveniente da solução de $\mathrm{HAuCl}_{4} \cdot 3 \mathrm{H}_{2} \mathrm{O}$.

Uma pipeta de Pasteur (Fischer 7095 B-9, 9") foi empregada como compartimento externo, no entanto, esta teve sua ponta afinada para aproximadamente $15 \mu \mathrm{m}$ por meio de aquecimento provido por resistência aquecedora. A membrana permeável ao oxigênio que foi utilizada foi feita de borracha de silicone sendo que esta foi introduzida na ponta do compartimento externo de modo que a mesma atingisse $10 \mu \mathrm{m}$ de espessura.

$\mathrm{O}$ eletrólito interno do microssensor consistiu em solução de $\mathrm{K}_{2} \mathrm{CO}_{3}(0,3 \mathrm{M}), \mathrm{KHCO}_{3}(0,2 \mathrm{M})$ e $\mathrm{KCl}(1,0 \mathrm{M}) \mathrm{em} \mathrm{pH}$ de 10,3 .

A inserção dos eletrodos no compartimento externo, bem como da membrana de silicone e eletrólito, para montagem final do microssensor, foi realizada com o auxílio do micromanipulador, microscópio (Olympus ${ }^{\circledR}-$ BX41) com câmera digital integrada (Samsung ${ }^{\circledR}$-SDC313) e seringas. Na Figura 4.2 se faz possível observar o microssensor de OD pronto para uso.

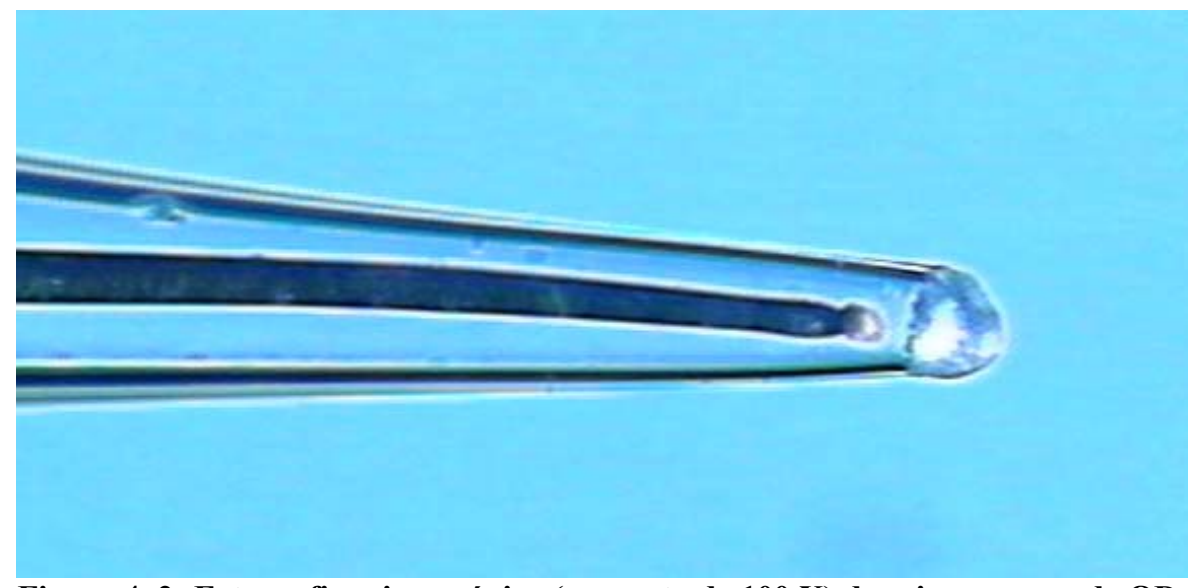

Figura 4. 2: Fotografia microscópica (aumento de $100 \mathrm{X}$ ) do microssensor de OD.

Como este microeletrodo se tratou de uma célula amperométrica, sua polarização foi feita catódicamente para aproximadamente $-0,8 \mathrm{~V}$ com picoamperímetro $\mathrm{HP}^{\circledR} 4140 \mathrm{~B}$ com fonte $\mathrm{DC}$ aclopada para realização das medições.

Para a calibração dos microssensores amperométricos de OD foram necessários apenas dois pontos, uma vez que a curva de calibração do mesmo é linear. Assim, os microeletrodos foram introduzidos alternadamente em ambientes com água saturada com ar e com nitrogênio (LEWANDOWSKI; BEYENAL, 2003). 


\subsection{3- Construção e calibração dos microssensores potenciométricos de íons nitrato $\left(\mathrm{NO}_{3}{ }^{-}\right)$, nitrito $\left(\mathrm{NO}_{2}{ }^{-}\right)$, amônio $\left(\mathrm{NH}_{4}{ }^{-}\right)$e $\mathrm{H}^{+}(\mathrm{pH})$}

Por se tratarem de dispositivos potenciométricos, os microeletrodos de íons nitrato, nitrito, amônio, e de $\mathrm{pH}$ foram construídos de modo bastante semelhante entre si, porém com apenas algumas particularidades que serão descritas adiante.

Estes microssensores constituíam-se dos seguintes componentes: eletrodo de referência interno de $\mathrm{Ag} / \mathrm{AgCl}$, eletrodo de referência externo de calomelano (Analion ${ }^{\circledR}$-G3779), membrana íon seletiva de troca iônica líquida (LIX-Liquid ion exchanger), solução eletrolítica interna e um compartimento externo.

O compartimento externo destes também foi feito de pipeta de Pasteur (Fischer 7095 B-9, 9”), a qual teve sua ponta afinada para diâmetros que variaram de 10 a $30 \mu \mathrm{m}$ por meio de uma resistência aquecedora. O eletrodo de referência interno foi obtido mediante deposição eletrolítica realizada de forma idêntica ao processo utilizado para obtenção do eletrodo de referência de $\mathrm{Ag} / \mathrm{AgCl}$ do microssensor de OD, descrito no tópico anterior a este (4.2.2).

Tanto as soluções eletrolíticas desses microssensores quanto suas membranas diferiram de acordo com o íon que cada um destinou-se a mensurar. As composições dos eletrólitos internos destes, bem como a especificação de suas membranas, encontram-se expostas na Tabela 4.2.

Tabela 4. 2: Composição eletrolítica e especificação das membranas dos microssensores potenciométricos.

\begin{tabular}{|c|c|c|}
\hline Microssensor & Solução eletrolítica & Membrana \\
\hline $\mathrm{NO}_{3}^{-}$ & $\begin{array}{l}\mathrm{KNO}_{3}-50 \mathrm{mM} \\
\mathrm{KCl}-50 \mathrm{mM}\end{array}$ & $\begin{array}{c}\text { coquetel de nonactina }(10 \%) \\
\text { Fluka }^{\circledR}-72549\end{array}$ \\
\hline $\mathrm{NO}_{2}^{-}$ & $\begin{array}{c}\mathrm{NaNO}_{2}-10 \mathrm{mM} \\
\mathrm{KCl}-10 \mathrm{mM} \\
\mathrm{Na}_{3} \mathrm{PO}_{4}-10 \mathrm{mM}\end{array}$ & $\begin{array}{c}\text { coquetel de aquacianocobalto(III)(7\%) } \\
\text { Fluka }^{\circledR}-72590\end{array}$ \\
\hline $\mathrm{NH}_{4}^{+}$ & $\mathrm{NH}_{4} \mathrm{Cl} 10 \mathrm{mM}$ & $\begin{array}{l}\text { coquetel ionóforo de íons amônio (I) } \\
\text { Fluka }^{\circledR}-09879\end{array}$ \\
\hline $\mathrm{pH}$ & $\begin{array}{c}\mathrm{NaCl}-100 \mathrm{mM} \\
\mathrm{KH}_{2} \mathrm{PO}_{4}-250 \mathrm{mM} \\
\mathrm{Na}_{2} \mathrm{HPO}_{4}-250 \mathrm{mM}\end{array}$ & $\begin{array}{c}\text { coquetel 4- nonadecilpiridina (6\%) } \\
\text { Fluka }^{\circledR}-95292\end{array}$ \\
\hline
\end{tabular}

As membranas utilizadas se tratavam de coquetéis prontos (Fluka ${ }^{\circledR}$ ) que continham em sua composição substâncias como polímero de alto peso molecular - policloreto de vinila (PVC) e tetrahidrofurano (THF), além dos ionóforos específicos para cada íon. Sabe-se que outros aditivos químicos fazem parte da composição dos referidos coquetéis, tais como sais derivados do tetrafenilborato e sais lipofílicos de amônia quaternária, entretanto suas proporções não são reveladas 
pela indústria que os fabrica. Substâncias como PVC e THF são adicionadas nos coquetéis para endurecimento dos mesmos e para que, consequentemente, o tempo de vida do microssensor seja prolongado e sua estabilidade mecânica aumentada.

É importante ressaltar que, infelizmente, a construção dos microssensores de detecção de íons nitrito $\left(\mathrm{NO}_{2}{ }^{-}\right)$se fez inviável ao longo do presente estudo devido a problemas relacionados à ausência do coquetel de aquacianocobalto (III) (7\%) $\left(\right.$ Fluka $^{\circledR}$ - 72590) no mercado fornecedor de reagentes químicos. A procura do coquetel em questão foi estendida até o término da presente pesquisa, sendo que nesta, fornecedores de outras marcas de reagentes químicos, tais como a Orion ${ }^{\circledR}$, Sigma $^{\circledR}$, Merck $^{\circledR}$ foram contatados sem sucesso. Dessa forma, os microssensores de íons nitrito não puderam ser manufaturados.

A montagem dos microssensores de $\mathrm{pH}, \mathrm{NH}_{4}{ }^{+}$e de $\mathrm{NO}_{3}{ }^{-}$também foi realizada com o auxílio de micromanipuladores, microscópio (Olympus $\left.{ }^{\circledR}-\mathrm{BX} 41\right)$ com câmera digital integrada (Samsung ${ }^{\circledR}$ SDC313) e seringas, contudo tem-se que esta consiste em procedimento menos complexo que o do microssensor de OD, já que os dispositivos potenciométricos possuem apenas um eletrodo no interior de seu compartimento externo.

Uma peculiaridade no modo de construção dos microeletrodos em questão se dá no momento que precede a inserção das membranas no compartimento externo dos mesmos. A realização de um processo conhecido como silanização, que possui como finalidade transformar a superfície de vidro da micropipeta de Pasteur afinada de hidrofílica para hidrofóbica, é imprescindível para aderência da membrana no compartimento externo destes microssensores. Tal processo foi feito mergulhando-se a ponta das micropipetas em solução de N-N-dimetiltrimetilsililamina (Fluka ${ }^{\circledR}$-41716) com posterior aquecimento das mesmas a temperatura de $200^{\circ} \mathrm{C}$ durante um período de 2 horas. Dessa forma, a superfície se torna hidrofóbica devido à presença de grupos metila $\left(\mathrm{CH}_{3}\right)$ no composto de silano utilizado que se ligam na mesma através de reação por via úmida (JONSSÖN; OLOFSSON, 1985).

Depois de prontos, os microssensores de íons nitrato, amônio e de $\mathrm{pH}$ foram calibrados com soluções que continham os íons $\mathrm{NO}_{3}{ }^{-}, \mathrm{NH}_{4}{ }^{+}$e $\mathrm{H}^{+}$, respectivamente. As soluções utilizadas para a calibração dos dois primeiros continham as mesmas concentrações, as quais se situaram dentro da faixa de $10^{-1}$ e $10^{-6} \mathrm{~mol} / \mathrm{L}$, porém, para a calibração do microssensor de íons nitrato soluções de nitrato de potássio $\left(\mathrm{KNO}_{3}\right)$ foram usadas e para o microssensor de íons amônio empregou-se soluções de cloreto de amônio $\left(\mathrm{NH}_{4} \mathrm{Cl}\right)$. Para a execução da calibração dos microeletrodos de $\mathrm{pH}$ soluções tampões de $\mathrm{pH}$ 4;7 e 10 foram utilizadas (de Beer et al., 1997). 


\subsection{4-Construção e calibração do microssensor para determinação de $\mathrm{H}_{2} \mathrm{~S}$}

Os microssensores de $\mathrm{H}_{2} \mathrm{~S}$ construídos foram do tipo amperométricos, baseados no mesmo princípio de funcionamento dos microssensores de OD do Tipo Clark, porém com algumas modificações realizadas por Jeroschewski et al. (1996).

Os microeletrodos combinados de $\mathrm{H}_{2} \mathrm{~S}$ consistiram em um compartimento externo, um eletrodo de trabalho feito de fio de platina (Pt) recoberto com vidro (catodo), um eletrodo de guarda (anodo), um contra-eletrodo, um eletrólito e uma membrana permeável ao sulfeto de hidrogênio $\left(\mathrm{H}_{2} \mathrm{~S}\right)$.

A construção do eletrodo de trabalho foi feita da seguinte maneira: um fio de platina com diâmetro inicial de $50 \mu \mathrm{m}$ teve sua ponta afinada para 5 a $10 \mu \mathrm{m}$ por meio de eletrólise feita com solução de cianeto de potássio $(\mathrm{KCN})$ saturada. Depois de afinado, introduziu-se o fio em capilar de vidro (borossilicato) e retraiu-se a ponta do vidro através de resistência aquecedora para que aproximadamente $5 \mu \mathrm{m}$ do fio de platina ficassem expostos.

O eletrodo de guarda teve seu processo de obtenção bastante similar ao do eletrodo de trabalho, exposto anteriormente, entretanto neste a ponta do vidro que recobria a platina foi retraída de modo que $2 \mathrm{~cm}$ da platina ficassem expostos.

Um fio de platina com diâmetro de $200 \mu \mathrm{m}$ foi utilizado como contra-eletrodo.

Uma pipeta de Pasteur (Fischer 7095 B-9, 9”) foi empregada novamente como compartimento externo e sua ponta foi afinada até atingir diâmetros que variaram entre $30 \mu \mathrm{m}$ a $50 \mu \mathrm{m}\left(\varnothing_{\mathrm{mem}}\right)$. A membrana utilizada se tratou de borracha de silicone que foi inserida por capilaridade na ponta da pipeta de Pasteur já afinada de modo que esta apresentasse espessura de aproximadamente $15 \mu \mathrm{m}$ de comprimento $\left(\mathrm{D}_{\mathrm{mem}}\right)$.

O eletrólito foi composto por uma solução de ferricianeto de potássio $\left(\mathrm{K}_{3} \mathrm{Fe}(\mathrm{CN})_{6}-50 \mathrm{mM}\right)$ diluído em tampão de carbonato $(0,5 \mathrm{M}) \mathrm{em}$ pH 10.

Sabendo-se que as dimensões dos eletrodos e as distâncias entre os mesmos influenciam diretamente no desempenho do microssensor em questão, a inserção dos eletrodos no interior do compartimento externo foi feita através do uso de micromanipuladores e microscópio (Olympus ${ }^{\circledR}$ BX41) com câmera digital integrada (Samsung ${ }^{\circledR}$-SDC313). Assim, o eletrodo de trabalho deveria distar de $30 \mu \mathrm{m}$ da membrana $\left(\mathrm{D}_{\mathrm{mem} / \mathrm{ET}}\right)$, e o eletrodo de guarda deveria ser colocado de forma que este distasse de 100 a $200 \mu \mathrm{m}\left(\mathrm{D}_{\mathrm{ET} / \mathrm{EG}}\right)$ do eletrodo de trabalho conforme ilustrado na Figura 4.3. 


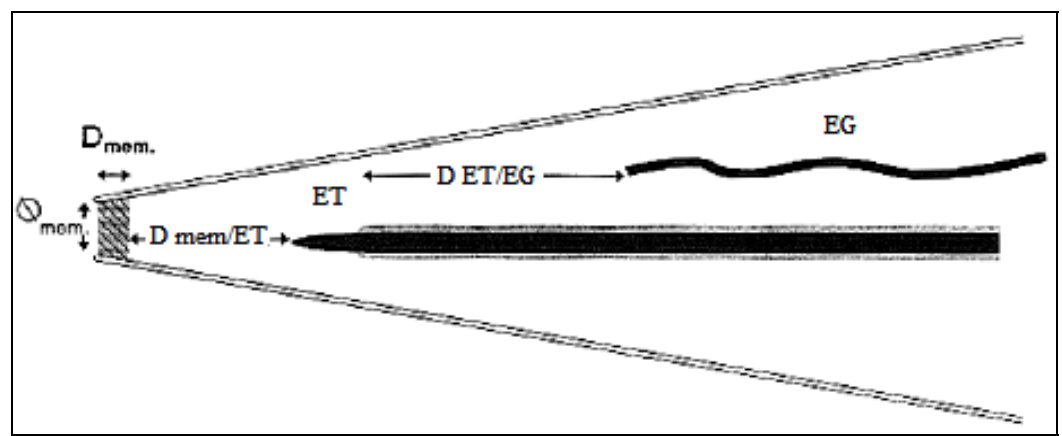

Figura 4. 3: Ilustração esquemática da região próxima a ponta de microssensor de $\mathrm{H}_{2} \mathrm{~S}$ (Fonte: JEROSCHEWSKI et al., 1996).

O eletrólito utilizado no microssensor foi composto por solução alcalina à base de ferricianeto de potássio, a qual é passível de decomposição por ação de luminosidade elevada devido à fotodegradação do complexo de hexacianoferrato (III) para pentacianoaquoferrato (III) (HOLLEMANN; WIBERG ${ }^{11}$, 1985 apud KUHL et al., 1998). Tal decomposição tem como consequência o aumento da corrente residual do sensor o qual induz a erros na determinação exata da concentração de $\mathrm{H}_{2} \mathrm{~S}$ da amostra a ser analisada.

Para minimização do efeito negativo causado pela luminosidade o microssensor foi submetido à pintura feita com tinta fosca de cor preta $\left(\right.$ Colorgin $\left.^{\circledR}\right)$. O microssensor de $\mathrm{H}_{2} \mathrm{~S}$ antes e depois de colorido de preto encontra-se exibido na Figura 4.4.

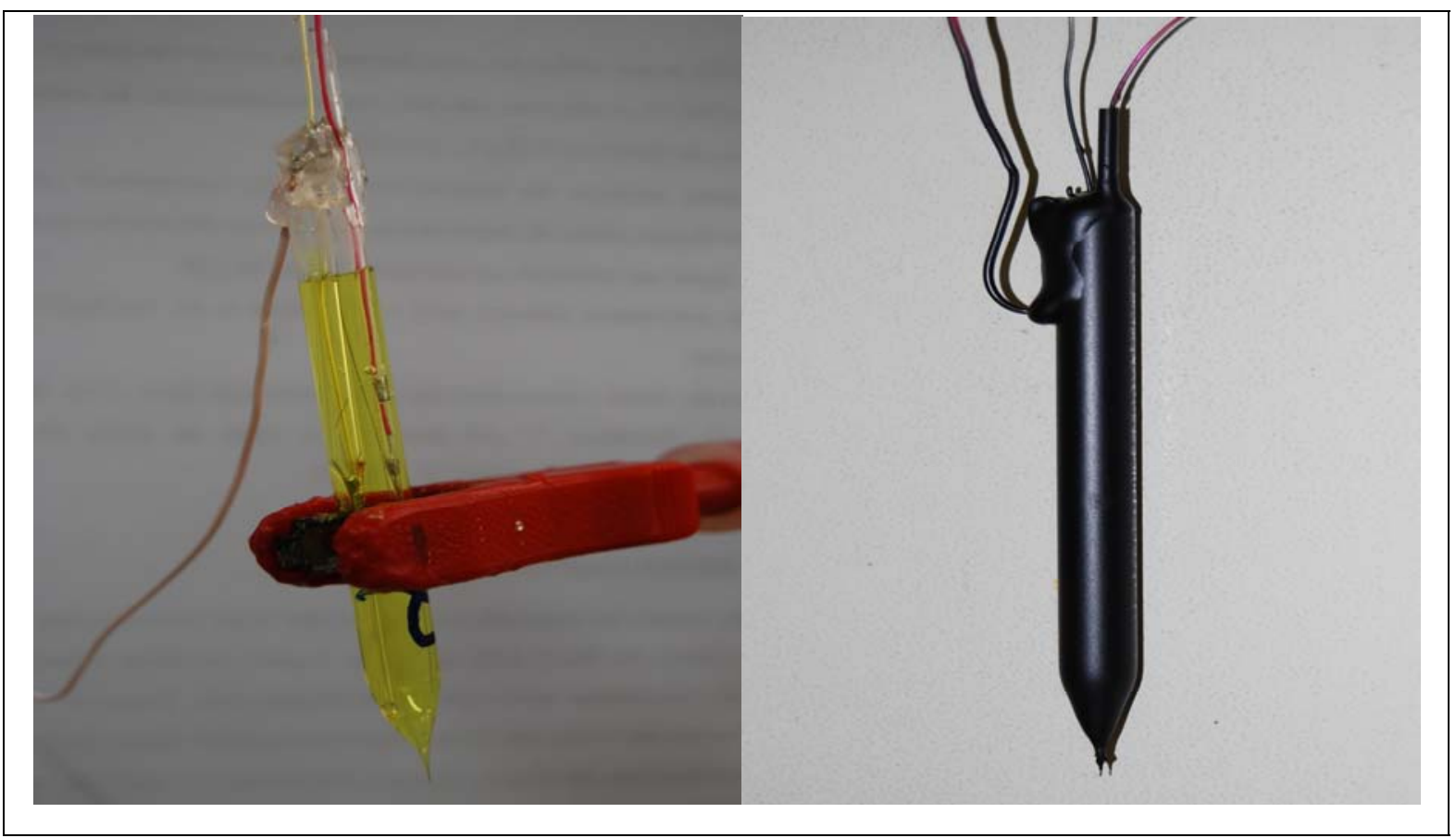

Figura 4. 4: Fotografia do microssensor de $\mathrm{H}_{2} \mathrm{~S}$ antes e depois de colorido de preto.

\footnotetext{
${ }^{11}$ HOLLEMANN, A.F.; WIBERG, E. (1985). Lehrbuch der Anorganischen Chemie. Walter de Gruyter, Berlin.
} 
Polarizaram-se então os eletrodos de guarda e de trabalho a $+150 \mathrm{mV}$ em oposição ao contraeletrodo através do uso de um picoamperímetro $\left(\mathrm{HP}^{\circledR} 4140 \mathrm{~B}\right)$ com fonte $\mathrm{DC}$ acoplada para realização das medições.

Para calibração dos microeletrodos de $\mathrm{H}_{2} \mathrm{~S}$, soluções de concentrações distintas de $\mathrm{H}_{2} \mathrm{~S}$ que variassem dentro da faixa de 1 a $300 \mu \mathrm{M}$, deveriam ser utilizadas. Para obtenção dessas soluções, foi feita a reação entre sulfeto de ferro $(\mathrm{FeS})$ e ácido clorídrico (PA) em um kitassato interligado a um balão contendo água destilada desaerada (obtida através do borbulhamento de nitrogênio durante 30 minutos na mesma) (Figura 4.5). A partir do aparato experimental montado, o gás sulfeto de hidrogênio gerado na reação entre o $\mathrm{FeS}$ e o $\mathrm{HCl}$ (Equação 4.1) era borbulhado na água contida no balão, resultando em uma solução concentrada de $\mathrm{H}_{2} \mathrm{~S}$.

$$
\mathrm{FeS}(\mathrm{s})+2 \mathrm{HCl}(\mathrm{l}) \rightarrow \mathrm{H}_{2} \mathrm{~S}(\mathrm{~g})+\mathrm{FeCl}_{2}
$$

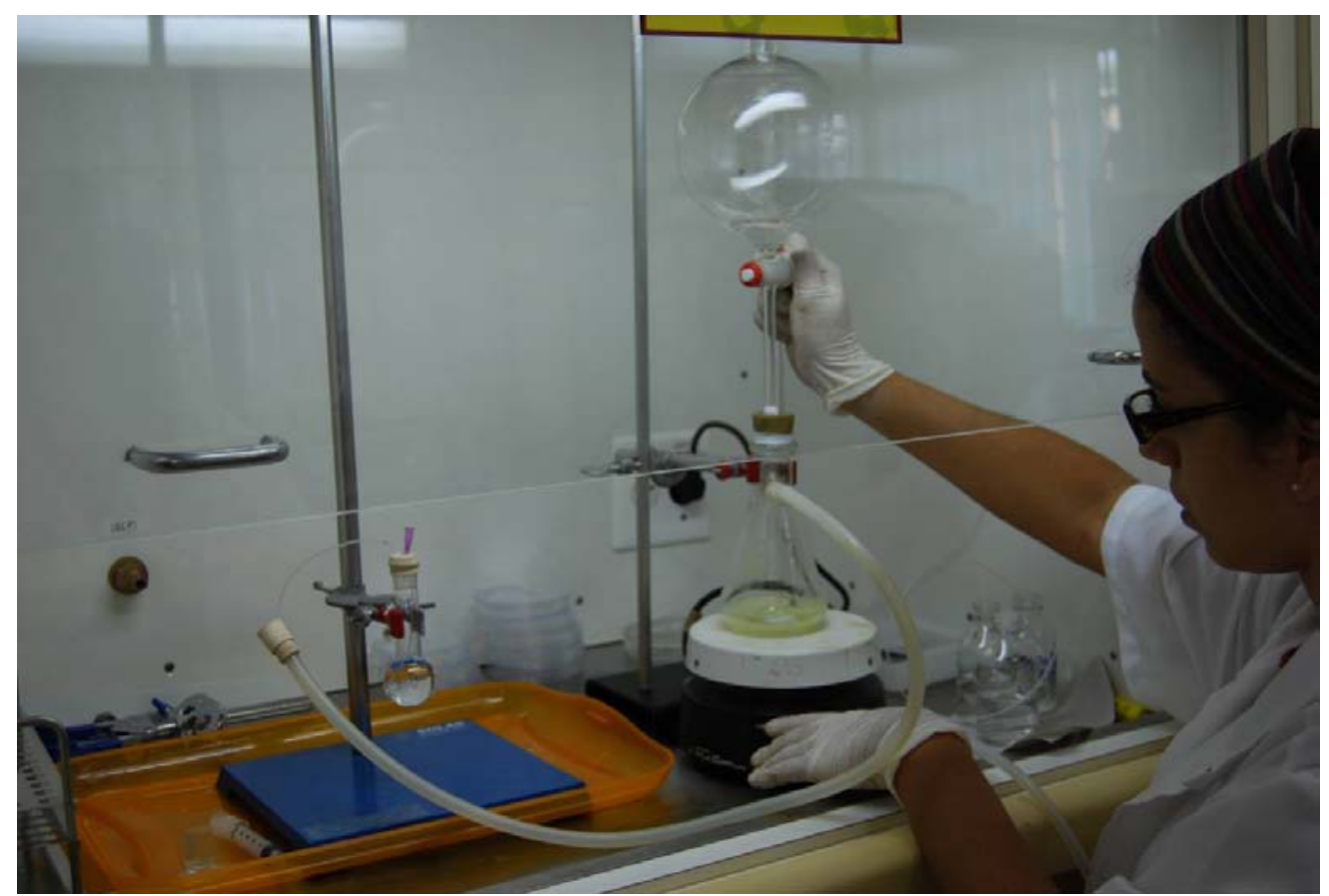

Figura 4. 5: Fotografia do aparato experimental utilizado para obtenção de solução concentrada de $\mathrm{H}_{2} \mathrm{~S}$.

A partir da solução concentrada de $\mathrm{H}_{2} \mathrm{~S}$ obtida (solução inicial) nesta etapa, diluições desta foram feitas. Contudo, antes disso a concentração da solução inicial tinha que ser determinada para que o cálculo dos fatores de diluições necessários para a obtenção das soluções provenientes desta pudesse ser realizado.

Para determinação da concentração da solução inicial utilizou-se método espectrofotométrico de detecção de íons sulfeto $\left(\mathrm{S}^{2-}\right)$ da $\operatorname{Hach}^{\circledR}$. Depois que a concentração desta foi determinada, diluições previamente calculadas foram realizadas para que soluções diluídas de $\mathrm{H}_{2} \mathrm{~S}$ dissolvido, que se situaram 
dentro da faixa de concentração de $\mathrm{H}_{2} \mathrm{~S}$ desejada, pudessem ser utilizadas na calibração dos microssensores de sulfeto de hidrogênio.

Cabe ressaltar que a obtenção das soluções diluídas de $\mathrm{H}_{2} \mathrm{~S}$ e a calibração desses microssensores, foram de difícil execução, visto que o sulfeto de hidrogênio é um gás altamente oxidável e volátil.

\section{3- Microssensores- Aprimoramentos e Testes}

\subsection{1- Eletrodos de $\mathrm{Ag} / \mathrm{AgCl}$ clorinizados}

Outro procedimento para obtenção do eletrodo de $\mathrm{Ag} / \mathrm{AgCl}$ foi proposto, visto que os eletrodos de $\mathrm{Ag} / \mathrm{AgCl}$, obtidos por processo de deposição eletrolítica, utilizados nos microssensores potenciométricos e no microssensor de OD sofriam degradação com o passar do tempo, a qual influenciava diretamente no desempenho dos mesmos.

Tal degradação era devida ao desprendimento do filme de cloreto de prata $(\mathrm{AgCl})$ do fio de prata (Ag) em que o primeiro se encontrava depositado e esta podia ser observada com facilidade, pois o eletrólito no qual o fio de prata estava mergulhado adquiria nova coloração, conforme apresentado na Figura 4.6.

$\mathrm{O}$ outro procedimento para obtenção do eletrodo de $\mathrm{Ag} / \mathrm{AgCl}$ sugerido consistia em deixar os fios de prata em repouso na solução eletrolítica do microssensor por período de tempo de 48 horas. Anteriormente ao início do procedimento, a solução eletrolítica era saturada com solução de cloreto de prata $(0,01 \mathrm{M})$. Passados os dois dias, os eletrodos de $\mathrm{Ag} / \mathrm{AgCl}$ estavam prontos para uso, contudo o microssensor em que este seria utilizado deveria ser preenchido com o eletrólito no qual os fios de prata ficaram mergulhados. Os eletrodos obtidos por tal processo foram chamados de eletrodos de $\mathrm{Ag} / \mathrm{AgCl}$ clorinizados.

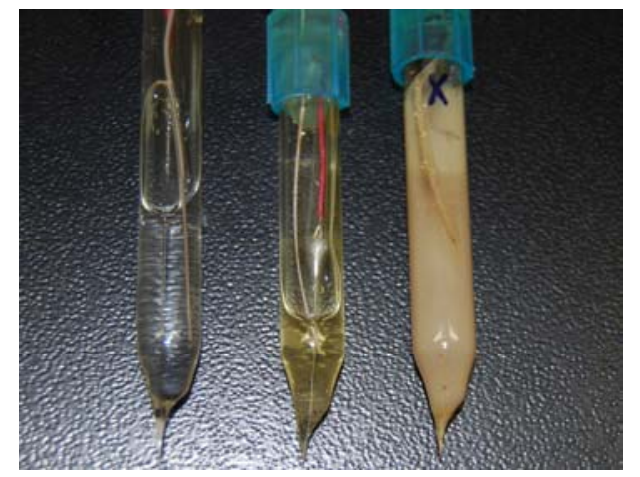

Figura 4. 6: Fotografia da evolução da degradação do eletrodo de Ag/AgCl em microssensores de OD. 
A fim de se avaliar o desempenho dos eletrodos de $\mathrm{Ag} / \mathrm{AgCl}$ obtidos via clorizinação, um microssensor de $\mathrm{OD}$ que continha dois eletrodos de $\mathrm{Ag} / \mathrm{AgCl}$, um obtido por eletrodeposição e outro por clorinização foi construído.

Os testes dos eletrodos de referência contidos no interior desse microssensor foram realizados ao longo de três meses. Esses foram feitos através da calibração dos mesmos, nas quais foi observado se com o passar do tempo ambos os tipos de eletrodo de $\mathrm{Ag} / \mathrm{AgCl}$ utilizados na construção do microssensor proporcionavam valores de corrente constante quando o microeletrodo era submetido a água saturada com oxigênio e com nitrogênio.

Também foram utilizadas como parâmetros de avaliação do funcionamento dos mesmos a resolução do microssensor com os dois tipos de eletrodos de $\mathrm{Ag} / \mathrm{AgCl}$, a velocidade de resposta dos mesmos e suas estabilidades na aquisição de medidas.

\subsection{2- Testes de Seletividade dos sensores potenciométricos}

Realizaram-se testes de seletividades com os microssensores potenciométricos de $\mathrm{pH}, \mathrm{NO}_{3}{ }^{-} \mathrm{e}$ $\mathrm{NH}_{4}{ }^{+}$. O objetivo desses foi o de verificar se tais sensores detectavam outros íons além dos que os mesmos deveriam detectar.

A determinação do coeficiente de seletividade potenciométrico $\left(\mathrm{K}_{A, B}^{P O T}\right)$ foi feita pelo Método das Soluções Separadas (UMEZAWA; UMEZAWA; SAT0, 1995). Realizou-se esse método da seguinte forma: sendo a espécie A o íon primário (o analito) e a espécie $\mathrm{B}$ o íon interferente, o potencial (E) de uma célula contendo somente o íon A na concentração $a_{A}$ foi medido. Em seguida o potencial de outra célula contendo apenas o íon $B$, na concentração $a_{B}\left(a_{B}=a_{A}\right)$ foi mensurado.

$\mathrm{O} \mathrm{K}_{A, B}^{P O T}$ foi calculado por meio da Equação (4.2):

$$
\log K_{A, B}^{P O T}=\frac{E_{2}-E_{1}}{2,303 \cdot \frac{R T}{z_{A} F}+\left(1-\frac{z_{A}}{z_{B}}\right) \log a_{A}}
$$

na qual $\mathrm{K}_{A, B}^{P O T}$ é o potencial de seletividade, $\mathrm{E}_{1}(\mathrm{~V})$ é o potencial medido da espécie $\mathrm{A}$ e $\mathrm{E}_{2}(\mathrm{~V})$ é o potencial da espécie interferente (B), R é constante dos gases $\left(8,31451 \mathrm{~J}^{-} \mathrm{K}^{-1} \cdot \mathrm{mol}^{-1}\right)$, T é temperatura absoluta (K), F é a constante de Faraday $\left(9,6485 \cdot 10^{4} \mathrm{C}_{\mathrm{mol}}{ }^{-1}\right), \mathrm{z}_{\mathrm{A}}$ e $\mathrm{z}_{\mathrm{B}}$ são as cargas das espécies A e B e $\mathrm{a}_{\mathrm{A}}$ é atividade de $\mathrm{A}$. 
Para execução do referido teste, três possíveis íons interferentes (B) foram analisados para cada tipo de microssensor potenciométrico (BAKKER; BUHLMANN; PRETSCH, 1999). Esses se encontram expostos na Tabela (4.3).

Tabela 4. 3: Íons interferentes (B) analisados para os microssensores de $\mathrm{pH}, \mathrm{NH}_{4}^{+}$e $\mathrm{NO}_{3}{ }^{-}$.

\begin{tabular}{|c|c|}
\hline Íon $\mathbf{A}$ & Íon B \\
\hline \hline $\mathrm{H}^{+}$ & $\mathrm{K}^{+}, \mathrm{Na}^{+}, \mathrm{NH}_{4}^{+}$ \\
\hline $\mathrm{NH}_{4}^{+}$ & $\mathrm{K}^{+}, \mathrm{Na}^{+}, \mathrm{H}^{+}$ \\
\hline $\mathrm{NO}_{3}^{-}$ & $\mathrm{NO}_{2}^{-}, \mathrm{HCO}_{3}^{-}, \mathrm{Cl}^{-}$ \\
\hline
\end{tabular}

As concentrações utilizadas, tanto para as soluções dos íons primários (A) quanto dos íons interferentes (B) foram as de $10^{-1}, 10^{-3}, 10^{-5}$ e $10^{-6} \mathrm{~mol} / \mathrm{L}$.

\section{4- Fatores limitantes relacionados à construção e armazenamento dos microssensores}

Por se tratarem de dispositivos até então indisponíveis no mercado brasileiro, empecilhos relacionados à escassez de materiais básicos necessários para construção e armazenamento tanto dos próprios microssensores quanto de seus constituintes, foram enfrentados.

\subsection{1- Adaptação e construção de materiais suportes para os microssensores}

Diversos objetos produzidos para fins conhecidos e desconhecidos foram utilizados para suprir a falta de materiais específicos para o armazenamento dos microeletrodos. Em alguns casos, esses objetos tiveram que ser totalmente modificados para que pudessem ser utilizados para determinados fins.

Dentre os objetos que foram utilizados sem que modificações em suas estruturas fossem realizadas, encontram-se os seguintes: ponteiras de micropipetas automáticas que serviram de suporte para os microssensores, suportes para ponteiras de micropipetas nos quais os microssensores localizados no interior das ponteiras foram sustentados, caixas de madeira nas quais pedaços de espuma foram colados para armazenamento dos catodos dos microeletrodos de $\mathrm{OD}$ e de $\mathrm{H}_{2} \mathrm{~S}$, entre outros (Figura 4.7).

Além da adaptação desses materiais, a qual foi feita visando à obtenção de condições adequadas de armazenamento dos microssensores, alguns suportes tiveram que ser inteiramente construídos para o mesmo fim. Este é o caso do suporte feito a partir de placas e bastões de vidro que foi usado na etapa de silanização dos compartimentos externos dos microssensores potenciométricos. $\mathrm{O}$ suporte desenvolvido, o qual foi de muita serventia durante a realização deste estudo, encontra-se apresentado na Figura 4.8. 


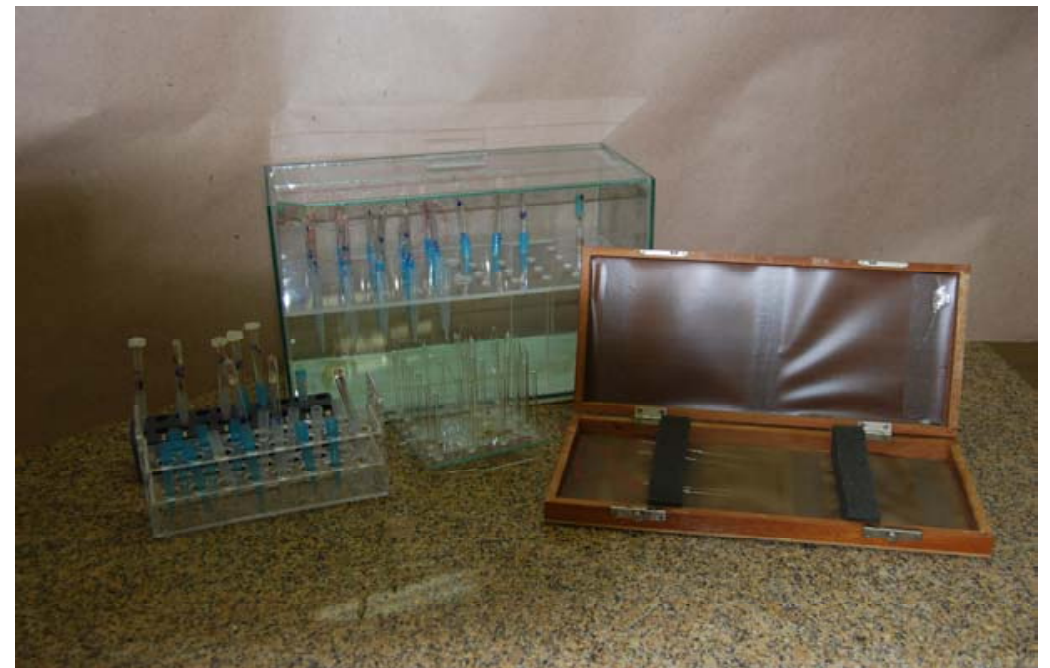

Figura 4. 7: Fotografia dos suportes adaptados para o armazenamento de microssensores e de seus constituintes.

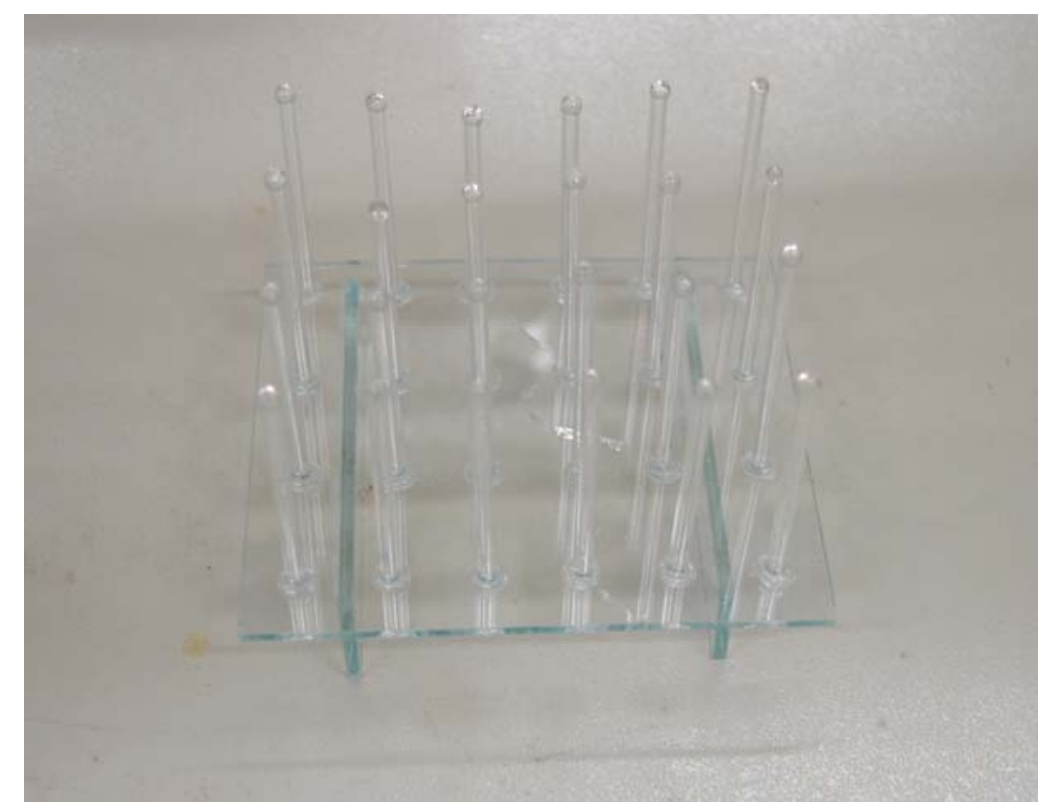

Figura 4. 8: Fotografia do suporte de compartimentos externos usado no processo de silanização.

Foi criado também um suporte para os fios de prata fossem clorinizados mediante procedimento já detalhado (Figura 4.9). Este foi feito a partir de recipiente de vidro de cor âmbar (volume de $1 \mathrm{~L}$ ) o qual era (anteriormente) utilizado para armazenamento de reagentes líquidos. A invenção deste também foi de muita utilidade ao longo da presente pesquisa. 


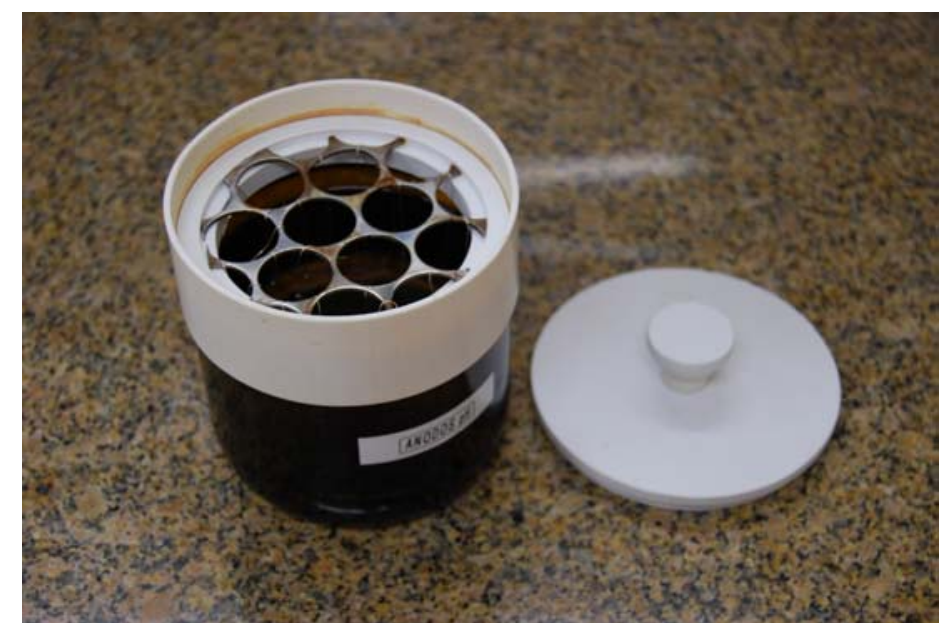

Figura 4. 9: Fotografia do suporte criado para clorinização dos fios de prata.

\subsection{2-Vidros - Problemas encontrados e suas soluções}

Diversas dificuldades foram encontradas na etapa de construção do eletrodo de trabalho do microssensor de OD. Essa se baseava na introdução do fio de platina (Pt) em um capilar de vidro que servia como revestimento do mesmo, sendo que depois que o fio era inserido, a ponta do capilar devia ser afinada através de derretimento propiciado por resistência aquecedora. Contudo, dependendo da composição do vidro, tal derretimento não ocorria de forma apropriada.

Detalhando melhor a construção do eletrodo em questão, tem-se que para obtenção dos capilares de vidro, tubos de vidro eram afinados primeiramente em chama de gás liquefeito de petróleo (GLP). Depois da inserção do fio de platina na ponta do capilar de vidro, este era posicionado em equipamento denominado de puller e aí então é que ocorria o revestimento da platina por meio da resistência aquecedora.

Depois de realizados alguns testes relacionados ao tipo de chama que deveria ser usado na etapa de obtenção do capilar de vidro foi notado que a substituição da chama proveniente de GLP por chama de gás propano $\left(\mathrm{C}_{3} \mathrm{H}_{8}\right)$ favorecia a obtenção de capilares de vidro com paredes menos espessas, de modo que o fio de platina era posteriormente melhor revestido. Essa mudança no procedimento de obtenção do catodo de OD foi a primeira a ser estabelecida.

Segundo Lewandowski (2006), vidros compostos por chumbo $(\mathrm{Pb})$ deveriam ser utilizados para revestimento do fio de platina. Entretanto vidros desse tipo não se encontram mais disponíveis no mercado nacional e internacional por questões ambientais. Dessa forma, vidros de borosilicato foram utilizados no recobrimento do fio de platina. Todavia, tal vidro continha paredes muito espessas, e quando esses eram utilizados para recobrimento da platina ocorria quebra da mesma. 
Assim, esses vidros foram substituídos por vidros que também eram de borosilicato, mas que continham paredes mais finas. Constatou-se, porém que os últimos apresentavam irregularidades em seus diâmetros e nas espessuras de suas paredes. Essas imperfeições somadas ao fato de que o vidro que estava sendo utilizado não era o recomendado (por falta de opção) resultavam no derretimento inadequado do mesmo.

O derretimento impróprio do vidro ocorria de diversas formas. Na maioria das vezes o calor provido pela resistência aquecedora não era suficiente para derreter as paredes de vidro do capilar no qual a platina se encontrava inserida e quando isso ocorria o capilar ficava exposto ao calor por um período maior de tempo. As consequências da exposição prolongada do capilar a altas temperaturas eram as formações de bolhas nas paredes do capilar (Figura 4.10) e as formações de "pêlo de vidro" na ponta do capilar (Figura 4.11).

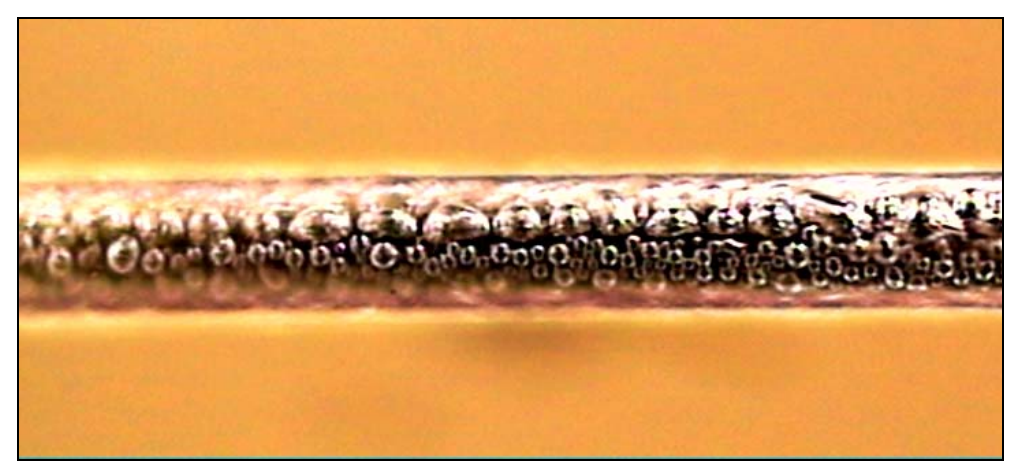

Figura 4. 10: Fotografia do capilar de vidro repleto de pequenas bolhas.

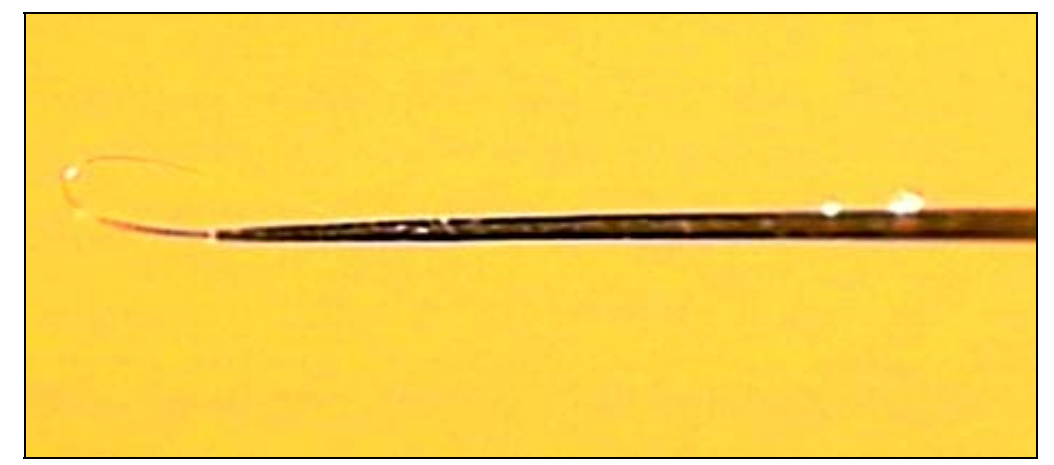

Figura 4. 11: Fotografia do catodo do microssensor de OD com "pêlo de vidro" em sua ponta.

As paredes irregulares dos capilares favoreciam o derretimento desigual dos mesmos fazendo com que ocorresse a formação de vãos entre o vidro e o fio de platina (Figura 4.12). 


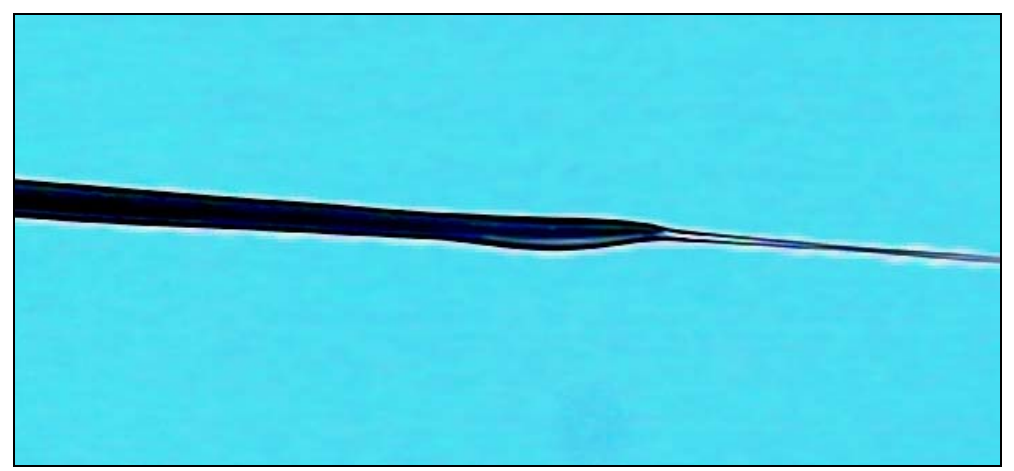

Figura 4. 12: Fotografia do catodo do microssensor de OD com vão entre o vidro e o fio de platina.

Para que os problemas expostos fossem solucionados, o formato da resistência aquecedora, responsável pelo derretimento do vidro no equipamento do tipo puller, foi modificado. O processo de obtenção desses eletrodos de trabalho também foi alterado, pois foi observado que quando temperaturas menores eram aplicadas nos capilares de vidro, não ocorria à formação de bolhas em suas paredes. Assim, utilizando-se a resistência aquecedora redimensionada e aplicando-se menos calor nos capilares de vidro por períodos de tempo maiores (para evitar a formação do "pêlo de vidro"), os mesmos passaram a apresentar formatos ideais (Figura 4.13).

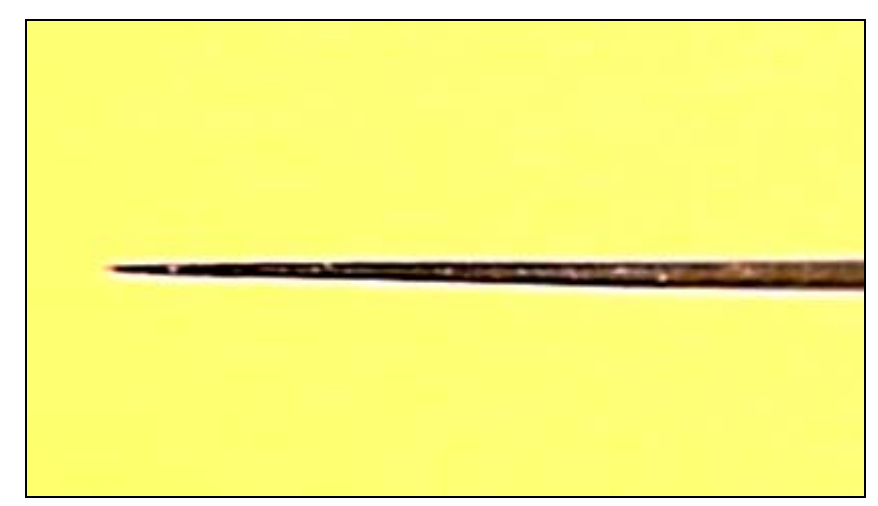

Figura 4. 13: Fotografia do eletrodo de trabalho (do microssensor de OD) ideal.

\section{5- Sistema utilizado para o desenvolvimento de biofilmes}

\subsection{1- Célula de Fluxo}

Os biofilmes estudados foram desenvolvidos em reatores de bancada, chamados de célula de fluxo. Esse tipo de reator, manufaturado, no caso, de policarbonato, foi escolhido para ser utilizado na presente pesquisa, pois o mesmo permite o crescimento de biofilme sob condições hidrodinâmicas previamente definidas. Além disso, a aplicação de microssensores, para quantificação de gradientes químicos no interior do biofilme aderido na superfície da célula de fluxo, é facilitada pelas dimensões da mesma, as quais são proporcionais aos tamanhos reduzidos dos microeletrodos. 
Os reatores do tipo célula de fluxo possuem as seguintes dimensões: $2,5 \mathrm{~cm}$ de largura, $4,0 \mathrm{~cm}$ de altura e $34,5 \mathrm{~cm}$ de comprimento (JACKSON et al., 2001). Sua área superficial é de $3,75 \mathrm{~cm}^{2}$ e seu volume útil é de $150 \mathrm{~mL}$. A Figura 4.14 ilustra o reator tipo célula de fluxo e a Figura 4.15 apresenta uma das células de fluxo utilizada no presente trabalho.

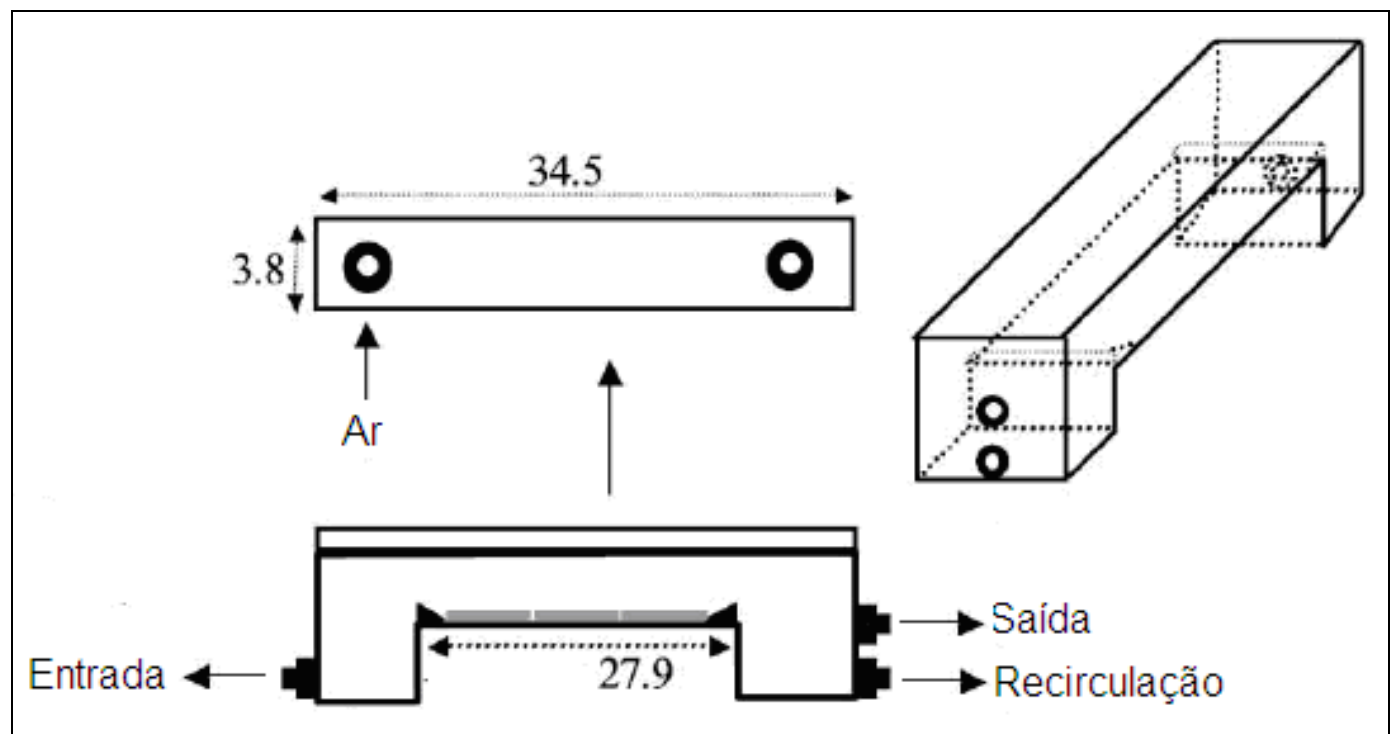

Figura 4. 14- Ilustração do reator tipo "célula de fluxo" (medidas em cm).

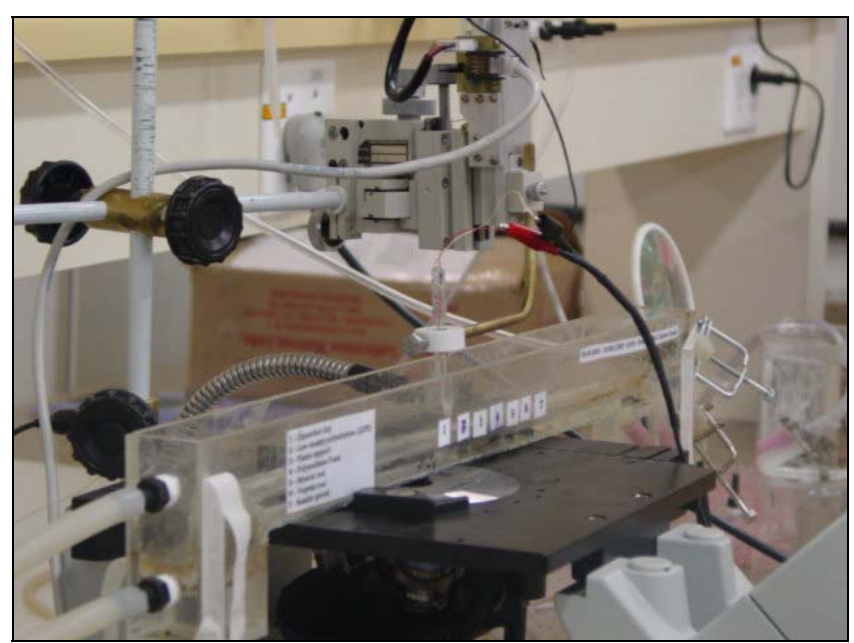

Figura 4. 15- Fotografia do reator tipo "célula de fluxo".

As operações das células de fluxo foram realizadas com a colaboração da mestranda Ana Lucia Gerardi Spínola, a qual sob orientação do Professor Dr. José Roberto Campos propôs em seu projeto acompanhar o desenvolvimento de biofilmes aeróbios em reatores do tipo célula de fluxo para a nitrificação de substrato sintético simulando efluente de UASB, submetidos a diferentes velocidades superficiais e taxas de carregamento de nitrogênio. 


\subsection{2- Considerações gerais relacionadas com as células de fluxo}

Ao longo da presente pesquisa, operaram-se células de fluxo em cinco experimentos distintos. As condições operacionais das mesmas diferiram entre cada experimento, entretanto o substrato sintético utilizado como alimentação dos sistemas constituídos pelas células de fluxo foi o mesmo. Lodo aeróbio proveniente de reator de Lodos Ativados localizado na Estação de Tratamento de Esgoto de Rio Claro (ETE das Flores) foi utilizado como inóculo das células de fluxo nos cinco experimentos realizados. Este era introduzido nas mesmas e recirculado por período de 4 horas. Depois, este era removido das células de fluxo por sistema a vácuo e a alimentação com o substrato sintético era iniciada.

Como o presente estudo incluía a construção e aplicação de microssensores para detecção de íons amônio, nitrato, $\mathrm{OD}$ e $\mathrm{pH}$ em biofilmes aplicados ao tratamento de água residuária e, mais especificamente, à nitrificação, optou-se pelo uso de esgoto sintético com concentrações de NTK de aproximadamente $40 \mathrm{mg} / \mathrm{L}$, e pela adoção de condições operacionais dos reatores que favorecessem o desenvolvimento de biofilmes nitrificantes.

Tal escolha pode ser justificada pelo fato de que assim sendo, a ocorrência da nitrificação no interior dos biofilmes formados nas superfícies das células de fluxo alimentadas pelo substrato sintético adotado, poderia ser criteriosamente verificada por meio dos microperfis de concentração dos íons nitrato, amônio, OD e pH.

O substrato sintético adotado simulava efluente de reator anaeróbio (UASB). O mesmo era preparado diariamente no decorrer de todas as operações dos reatores de bancada, e possuía as seguintes características: concentrações de NTK de $40 \pm 10 \mathrm{mg} / \mathrm{L}$, DQO de $95 \pm 5 \mathrm{mg} / \mathrm{L}$, alcalinidade de 180 $\mathrm{mgCaCO}_{3} / \mathrm{L}$ e $\mathrm{pH}$ igual a 7,5 (SPÍNOLA, 2009). As quantidades dos componentes orgânicos e inorgânicos utilizados para que substrato sintético com tais características fosse obtido encontram-se na Tabela 4.4.

Além dos componentes citados, o substrato foi enriquecido com soluções de sais minerais propostas por Torres (1996), porém algumas alterações concernentes à quantidade dos mesmos foram feitas com o intuito de se obter substrato sintético com concentrações de sais minerais similares as encontradas comumente no efluente de UASB (CAMPOS, 2007) (Tabela 4.5). 
Tabela 4. 4 - Quantidades de componentes orgânicos e inorgânicos presentes no substrato

\begin{tabular}{|c|c|}
\hline Composto Orgânico/Inorgânico & Quantidade $\left(\mathrm{mg} . \mathrm{L}^{-1}\right)$ \\
\hline \hline Sacarose & 30,0 \\
\hline Amido & 30,0 \\
\hline Óleo de soja & $12,7^{*}$ \\
\hline $\mathrm{CH}_{3} \mathrm{COOH}$ & 22,0 \\
\hline $\mathrm{NH}_{4} \mathrm{Cl}$ & 125,0 \\
\hline $\mathrm{NaHCO}_{3}$ & 445,0 \\
\hline
\end{tabular}

* quantidade da ordem de 1 gota

Tabela 4. 5 - Soluções de sais minerais acrescentadas ao substrato sintético

\begin{tabular}{|c|c|c|}
\hline Sal & Concentração $(\mathrm{g} / 100 \mathrm{~mL})$ & $\begin{array}{c}\text { Volume da solução para } \\
\text { 1L de meio }(\mathrm{mL})\end{array}$ \\
\hline \hline Solução 1 ( $\left.\mathrm{K}_{2} \mathrm{HPO}_{4}\right)$ & 0,60 & 3,75 \\
\hline Solução 2 & 0,60 & \\
$\mathrm{KH}_{2} \mathrm{PO}_{4}$ & 1,20 & 17,35 \\
$\mathrm{NaCl}$ & 0,20 & \\
$\mathrm{MgCl}_{2} \cdot 6 \mathrm{H}_{2} \mathrm{O}$ & 0,16 & \\
$\mathrm{CaCl}_{2} \cdot 2 \mathrm{H}_{2} \mathrm{O}$ & 1,00 & \\
\hline Solução 3 $\left(\mathrm{FeSO}_{4} \cdot 7 \mathrm{H}_{2} \mathrm{O}\right)$ & 0,78 & 5,00 \\
\hline Solução 4 $\left(\mathrm{Na}_{2} \mathrm{~S}\right)$ & & 1,00 \\
\hline
\end{tabular}

Fonte: Adaptado de Torres (1992)

É importante salientar que em todos os experimentos, antes do lodo de inóculo ser introduzido nas células de fluxo, procedimento de esterilização das mesmas era efetivado. Neste as células de fluxo eram lavadas e esterilizadas com água clorada $0,02 \%$ por 2 horas. As mangueiras de silicone que seriam posteriormente conectadas nas células de fluxo, para alimentação e recirculação do substrato sintético nas mesmas, eram autoclavadas a temperatura de $120^{\circ} \mathrm{C}$ sob pressão de $1 \mathrm{~atm}$ por 15 minutos. Depois, recirculava-se água destilada para a remoção completa do cloro do sistema por um período de tempo de 24 horas. Após execução da desinfecção das células de fluxo, as mesmas eram inoculadas e posteriormente operadas. 


\subsection{3- Sistema completo utilizado nos experimentos}

Os dois primeiros experimentos ( 1 e 2) realizados no presente trabalho incluíram a operação de apenas uma célula de fluxo, enquanto que os três experimentos seguintes a esses (experimentos A, B e C) abrangeram a operação simultânea de três células de fluxo.

A montagem experimental exposto na Figura 4.16 ilustra o sistema completo montado, através do qual as conexões da célula de fluxo, a aeração (mantida constante) provida por compressor de ar interligado na mesma e a aplicação do microssensor no interior do biofilme localizado em sua superfície podem ser observadas.

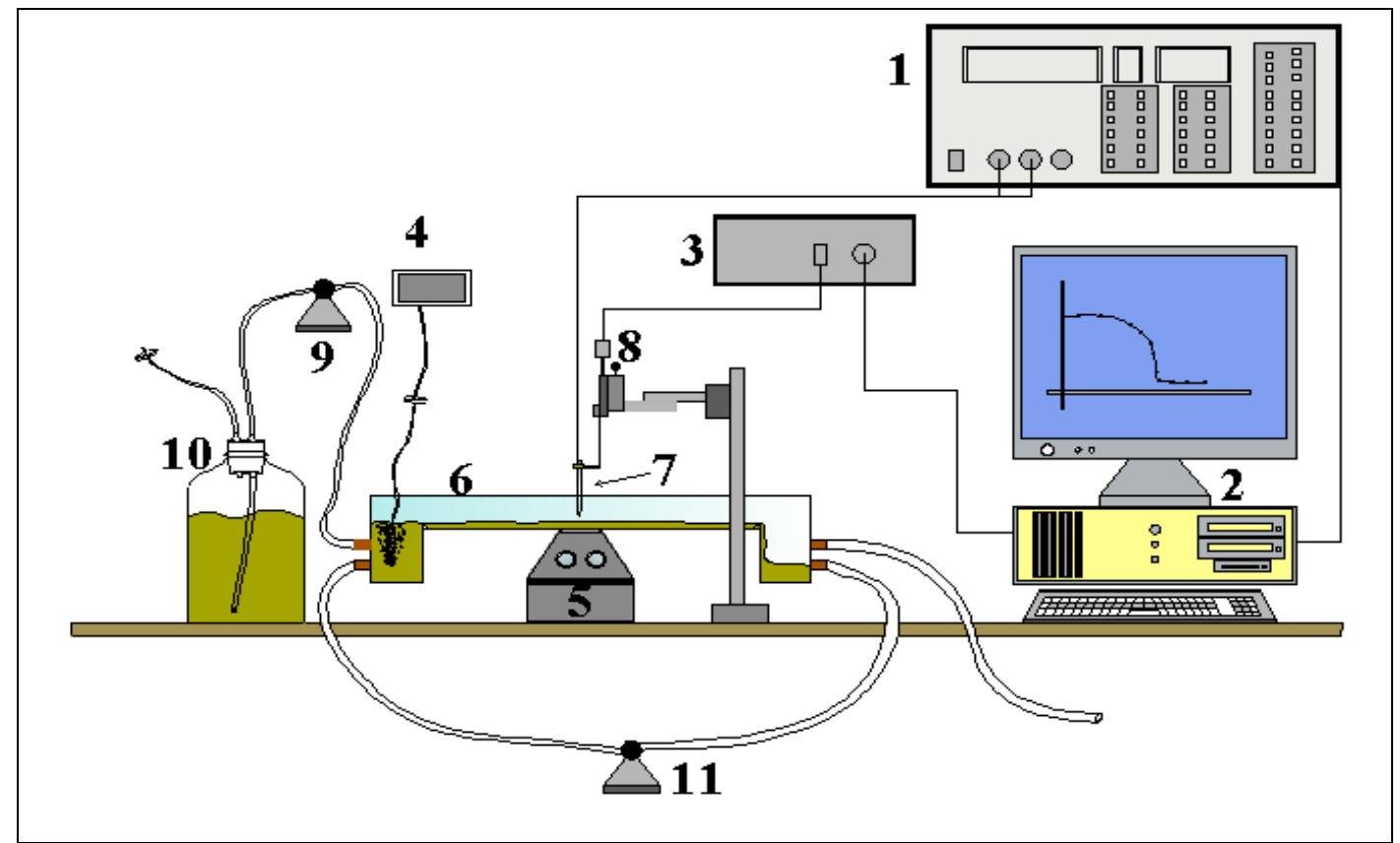

Figura 4. 16: Ilustração do Sistema completo. 1-Picoamperímetro; 2-Computador; 3-driver do servo-motor; 4compressor de ar (Big Air $\left.{ }^{\circledR}-A 420\right)$; 5- microscópio invertido (Olympus ${ }^{\circledR}$-IX51) integrado com câmera digital (Samsung ${ }^{\circledR}$-SDC-313); 6-célula de fluxo; 7-microssensor; 8-servo-motor e micromanipulador; 9-bomba peristáltica; 10-substrato sintético; 11-bomba peristáltica.

\subsection{4- Condições operacionais da célula de fluxo - Experimento 1}

Esse experimento visava à identificação do período de tempo necessário para que o biofilme desenvolvido na superfície da célula de fluxo apresentasse zonas anaeróbias nas regiões mais profundas e à verificação da viabilidade de estudar o crescimento de biofilme nitrificante aeróbio no reator de bancada escolhido. Para tanto nesse se operou apenas uma célula de fluxo e o monitoramento diário do crescimento do biofilme formado na mesma foi obtido via microssensores de OD e por meio de micrografias. 
Conforme mencionado no tópico 4.5.2, o protocolo de esterilização da célula de fluxo foi cumprido antes da inoculação da célula de fluxo e apenas depois de inoculada a alimentação com substrato sintético foi iniciada na célula de fluxo.

Os parâmetros operacionais da célula de fluxo foram os seguintes: a vazão de alimentação adotada foi de $24 \mathrm{~mL} / \mathrm{h}$, valor referente à taxa de carregamento de $1,5 \mathrm{~g} \mathrm{~N} / \mathrm{m}^{2}$ biofilme.dia. A velocidade superficial empregada foi de $1 \mathrm{~m} / \mathrm{h}$, sendo que a mesma correspondeu a uma vazão de recirculação de $0,375 \mathrm{~L} / \mathrm{h}$. Assim, a célula de fluxo foi alimentada com o substrato sintético por meio do uso de bomba peristáltica (Gilson ${ }^{\circledR}$ - Minipuls 3) e o mesmo foi recirculado pela ação da bomba peristáltica da marca Masterflex ${ }^{\circledR}$ - 77120-62. A operação da célula de fluxo teve duração de cinco dias, nos quais a temperatura ambiente foi mantida em $25 \pm 1{ }^{\circ} \mathrm{C}$.

O monitoramento das condições de operação do sistema foi realizado a partir de análises físicoquímicas de NTK, pH, alcalinidade, DQO, íons nitrato e nitrito do afluente e efluente do reator de bancada. As análises de NTK foram feitas pelo método de Kjeldahl, as de pH através do uso de pHmetro (Orion ${ }^{\circledR}-410 \mathrm{~A}$ ), as de nitrito e nitrato por análise de injeção em fluxo (FIA), a de alcalinidade por titulação com ácido sulfúrico e a de DQO por espectrofotometria (APHA, 2001).

\subsection{5- Condições operacionais da célula de fluxo - Experimento 2}

Neste experimento a quantidade de células de fluxo operadas e o procedimento de esterilização da mesma foram análogos ao que foi utilizado no experimento 1. Contudo foram feitas mudanças relacionadas, tanto com a taxa de carregamento de nitrogênio quanto com a velocidade superficial da célula de fluxo. A nova taxa de carregamento adotada foi de $0,5 \mathrm{~g} \mathrm{~N} / \mathrm{m}^{2}$ biofilme.dia $\left(\mathrm{Q}_{\mathrm{e}}=7,9 \mathrm{~mL} / \mathrm{h}\right.$ provida por bomba peristáltica da Gilson ${ }^{\circledR}$ - Minupuls 3) e a velocidade superficial empregada foi de $8 \mathrm{~m} / \mathrm{h}$ $\left(\mathrm{Q}_{\text {rec. }}=3 \mathrm{~L} / \mathrm{h}\right.$ mediante bomba peristáltica Provitec ${ }^{\circledR}-\mathrm{AWG5000).}$

Novamente, microperfis de OD diários e micrografias foram utilizadas como ferramentas de acompanhamento do crescimento do filme microbiano aderido na superfí́cie interna molhada da célula de fluxo.

Salienta-se que esse ensaio teve como objetivo a determinação do tempo de operação necessário para que o biofilme desenvolvido na superfície da célula de fluxo se tornasse anaeróbio sob condições operacionais distintas das adotadas no experimento 1.

Análises físico-químicas das mesmas variáveis mensuradas no experimento 1 foram feitas por meio das mesmas técnicas analíticas. 


\subsection{6- Condições operacionais - Experimento A}

No experimento em questão fez-se uso de protocolos similares aos dos experimentos 1 e 2 . Procedimento de esterilização idêntico ao detalhado nos primeiros ensaios foi efetuado.

No entanto, neste operaram-se três células de fluxo ao mesmo tempo, sendo que a taxa de carregamento adotada para as mesmas foi de $0,5 \mathrm{~g} \mathrm{~N} / \mathrm{m}^{2}$ biofilme.dia $\left(\mathrm{Q}_{\mathrm{e}}=7,9 \mathrm{~mL} / \mathrm{h}\right)$. As velocidades superficiais aplicadas nas células $1 ; 2$ e 3 foram às seguintes: $1 \mathrm{~m} / \mathrm{h}, 8 \mathrm{~m} / \mathrm{h}$ e $4 \mathrm{~m} / \mathrm{h}\left(\mathrm{Qs}_{\text {rec. }}=0,375 \mathrm{~L} / \mathrm{h}, 3\right.$ $\mathrm{L} / \mathrm{h}$ e $1,5 \mathrm{~L} / \mathrm{h}$ ), respectivamente. Vale salientar que a taxa de carregamento de nitrogênio e as velocidades superficiais adotadas neste foram regidas pelas interpretações dos resultados obtidos nos experimentos 1 e 2. A Figura 4.17 apresenta as três células de fluxo operadas no presente.

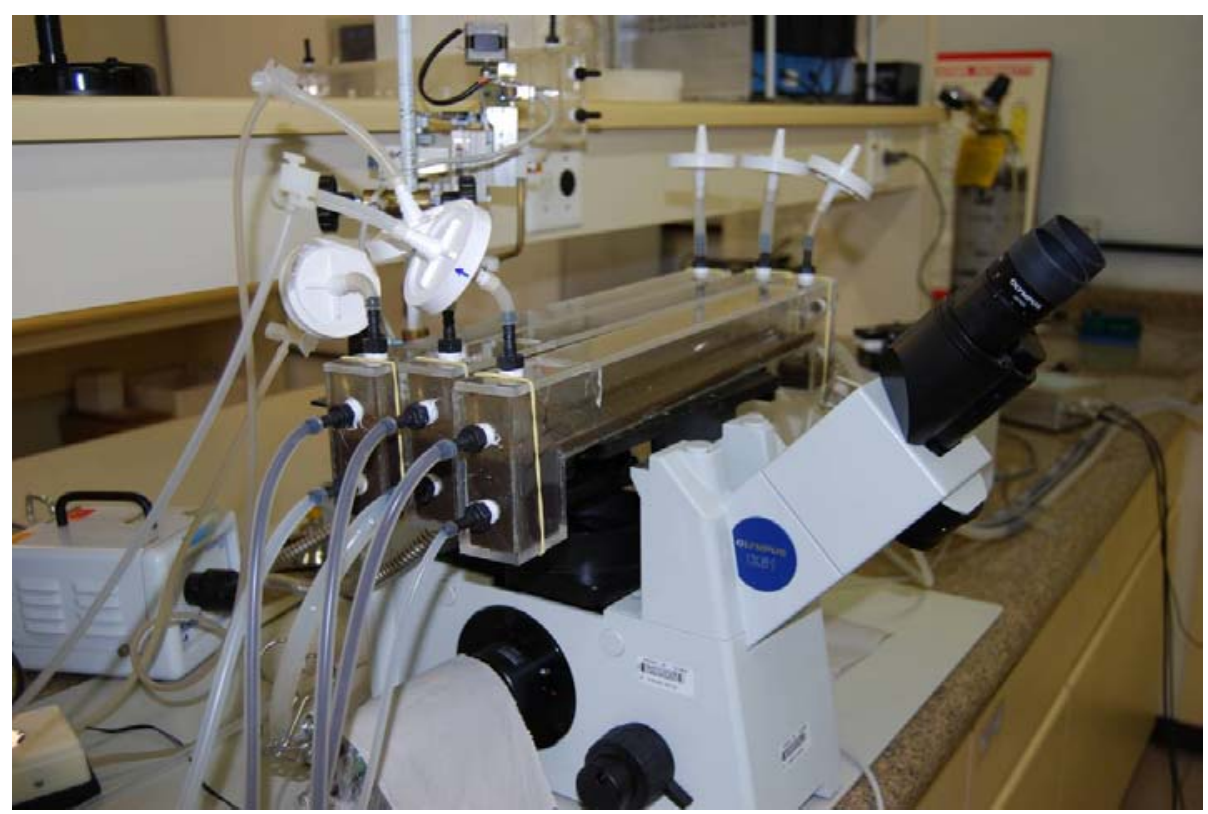

Figura 4. 17: Fotografia das três células de fluxo em operação no experimento A.

Além das medições de $\mathrm{OD}$, microssensores para detecção de íons $\mathrm{H}^{+}(\mathrm{pH})$ e íons $\mathrm{NO}_{3}{ }^{-}$também foram aplicados nos biofilmes aderidos nas células de fluxo. Esses últimos foram utilizados tanto para avaliação de seus desempenhos como também para que os consumos de OD no interior dos biofilmes pudessem ser comparados aos valores de $\mathrm{pH}$ e de concentração dos íons nitrato medidos nos mesmos.

As mesmas análises físico-químicas executadas nos experimentos anteriores foram feitas para determinação das variáveis dos afluentes e efluentes das células de fluxo.

\subsection{7- Condições operacionais - Experimento B}

Esse experimento foi realizado de maneira muito similar ao anterior, ou seja, foram operadas três células de fluxo, as quais foram previamente esterilizadas através do mesmo procedimento do 
experimento A. O monitoramento das condições operacionais do sistema também seguiu o mesmo protocolo do ensaio anterior.

De acordo com os resultados obtidos no experimento A, decidiu-se por aumentar a taxa de carregamento dos reatores para $1 \mathrm{~g} \mathrm{~N} / \mathrm{m}^{2}$ biofilme.dia $\left(\mathrm{Q}_{\mathrm{e}}=16 \mathrm{~mL} / \mathrm{h}\right)$. Os valores das velocidades superficiais dos três reatores foram mantidos, portanto os mesmos nas células de fluxo 1; 2 e 3 foram de $1 \mathrm{~m} / \mathrm{h}, 8 \mathrm{~m} / \mathrm{h}$ e $4 \mathrm{~m} / \mathrm{h}$, na devida ordem $\left(\mathrm{Qs}_{\mathrm{rec}}=0,375 \mathrm{~L} / \mathrm{h}, 3 \mathrm{~L} / \mathrm{h}\right.$ e $\left.1,5 \mathrm{~L} / \mathrm{h}\right)$.

Outra distinção desse experimento recaiu no fato de que neste, além da microperfilação feita com os microssensores de $\mathrm{OD}, \mathrm{pH}$ e íon $\mathrm{NO}_{3}{ }^{-}$, realizaram-se mensurações dê íons amônio $\mathrm{NH}_{4}{ }^{+}$ao longo das espessuras dos biofilmes com os microeletrodos para detecção destes.

\subsection{8- Condições operacionais - Experimento C}

Tal experimento foi feito exatamente da mesma forma que o anterior, portanto os detalhes de operação deste foram idênticos aos do ensaio $\mathrm{B}$, com exceção da taxa de carregamento das células de fluxo, que neste foi reduzida para $0,25 \mathrm{~g} \mathrm{~N} / \mathrm{m}^{2}$ biofilme.dia $\left(\mathrm{Q}_{\mathrm{e}}=4 \mathrm{~mL} / \mathrm{h}\right)$. As velocidades superficiais das células de fluxo operadas nesse experimento foram idênticas às adotadas nos experimentos $\mathrm{A}$ e B: $\mathrm{Qs}_{\mathrm{rec} .}=0,375 \mathrm{~L} / \mathrm{h}, 3 \mathrm{~L} / \mathrm{h}$ e $1,5 \mathrm{~L} / \mathrm{h}$.

$\mathrm{Na}$ Tabela 4.6, encontram-se expostas as taxas de carregamento de nitrogênio das células de fluxo operadas e suas referentes vazões de entrada assim como as velocidades superficiais adotadas para as mesmas e suas correspondentes vazões de recirculação, utilizadas em todos os experimentos realizados na presente pesquisa.

Tabela 4. 6: Condições Operacionais adotadas nos experimentos realizados no presente estudo.

\begin{tabular}{|c|c|c|c|c|}
\hline Experimento & $\begin{array}{l}\text { Taxa de Carregamento de } \\
\text { Nitrogênio }\left(\mathrm{g} \mathrm{N} / \mathrm{m}^{2}{ }_{\text {biofilme.dia }} \text { ) }\right.\end{array}$ & $\begin{array}{l}\text { Qentrada } \\
(\mathbf{m L} / \mathbf{h})\end{array}$ & $\begin{array}{c}\text { Velocidade } \\
\text { Superficial }(\mathrm{m} / \mathrm{h})\end{array}$ & $Q_{\text {recirculação }}(L / h)$ \\
\hline$\overline{1}$ & 1,50 & 24,00 & 1,00 & 0,37 \\
\hline 2 & 0,50 & 7,90 & 8,00 & 3,00 \\
\hline A & 0,50 & 7,90 & 1,$00 ; 4,00 ; 8,00$ & 0,$37 ; 3,00 ; 1,50$ \\
\hline B & 1,00 & 16,00 & 1,$00 ; 4,00 ; 8,00$ & 0,$37 ; 3,00 ; 1,50$ \\
\hline $\mathrm{C}$ & 0,25 & 4,00 & 1,$00 ; 4,00 ; 8,00$ & 0,$37 ; 3,00 ; 1,50$ \\
\hline
\end{tabular}




\section{5- RESULTADOS E DISCUSSÃO}

\section{1- Calibrações dos microssensores}

Seguindo as recomendações da IUPAC (1976), as curvas de calibração dos microssensores potenciométricos ( $\mathrm{pH}$, íons nitrato e amônio) foram plotadas de forma que os potenciais mensurados pelos mesmos se situaram no eixo y e os logaritmos das concentrações das soluções do analito (em mol/L) localizaram-se no eixo $x$. Para os microssensores amperométricos de $\mathrm{OD}$ e $\mathrm{H}_{2} \mathrm{~S}$ as curvas de calibração foram representadas com os sinais de corrente no eixo $y$ contra as concentrações das referidas espécies no eixo $x$ (em mol/L para os microssensores de $\mathrm{H}_{2} \mathrm{~S}$ e em $\mathrm{mg} / \mathrm{L}$ para os de OD).

\subsection{1- Microssensores de OD}

Conforme já detalhado anteriormente, a calibração dos microssensores de OD baseava-se em curvas que continham apenas dois pontos, pois segundo Hitchman (1978) a curva de calibração de microssensores de OD é linear e para obtenção da mesma são necessários somente dois pontos.

A Figura 5.1 contém a curva de calibração média dos microssensores de OD utilizados ao longo da presente pesquisa. É importante ressaltar que essa foi extraída de quarenta curvas obtidas mediante calibrações dos microssensores em questão, nas quais as correntes mensuradas variaram dentro da faixa de 80 a 350 pA quando os microssensores foram submetidos à água saturada com nitrogênio $\left(\mathrm{N}_{2}\right)$, situação na qual concentração nula de oxigênio dissolvido no meio era promovida, e no intervalo de 450 a 950 pA quando os mesmos foram introduzidos em água saturada com oxigênio ( $\mathrm{OD}=7,8 \mathrm{mg} / \mathrm{L})$.

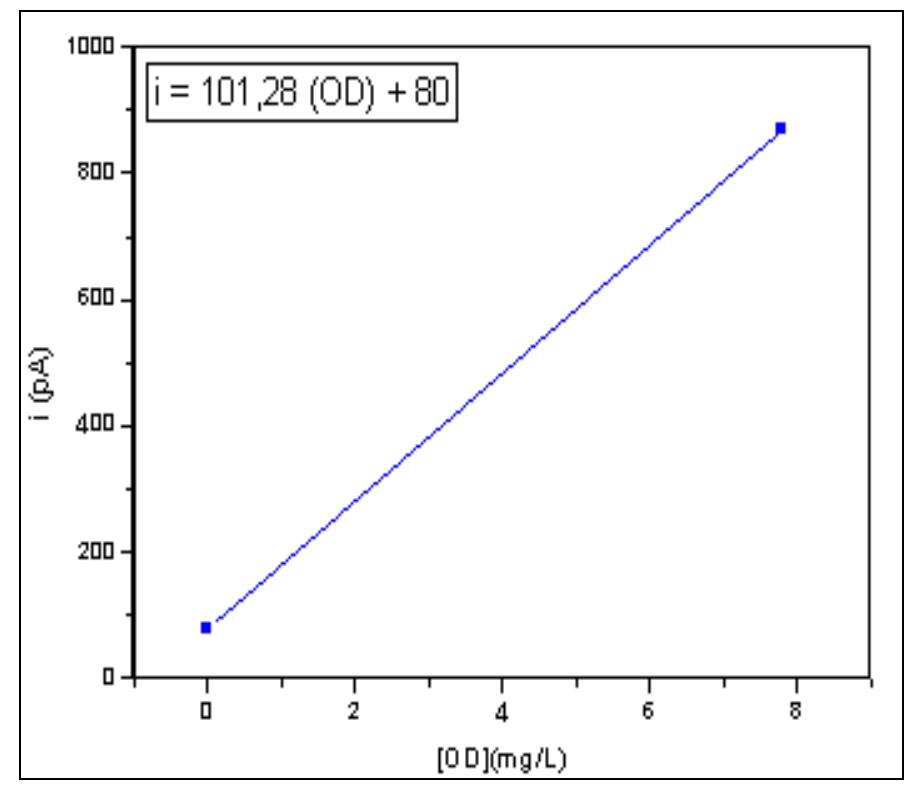

Figura 5. 1: Curva de calibração média dos microssensores de $\mathrm{OD}\left(\mathrm{T}=25 \pm 2^{\circ} \mathrm{C}\right)$. 
O gráfico da Figura 5.2 ilustra o comportamento típico dos microssensores de OD no decorrer de suas calibrações.

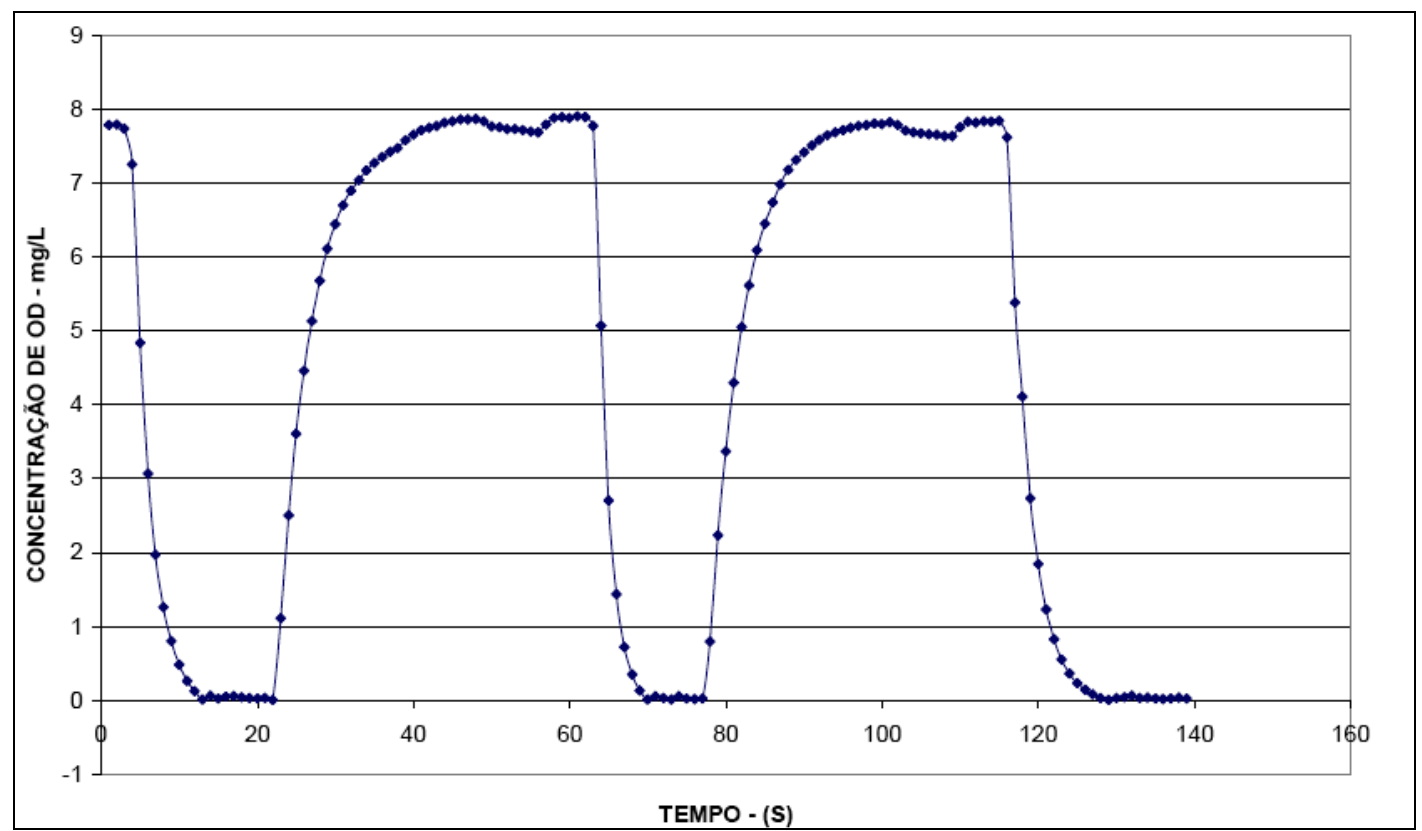

Figura 5. 2: Comportamento típico dos microssensores de OD durante a calibração $\left(\mathrm{T}=25 \pm 2^{\circ} \mathrm{C}\right)$.

Constatou-se neste gráfico que o sinal de corrente decrescia instantaneamente quando os microssensores eram submetidos a condições de ausência de oxigênio dissolvido no meio e quando estes eram sujeitos a soluções saturadas com oxigênio nas quais as concentrações de OD se igualavam a 7,8 mg/L, o sinal da corrente aumentava rapidamente. Observou-se também neste que o tempo de resposta dos microssensores construídos e calibrados era inferior a $1 \mathrm{~s}$.

\subsection{2- Microssensores de $\mathrm{pH}$}

A Figura 5.3 (A) apresenta dez curvas de calibração obtidas com microssensores de pH. O valor do $\mathrm{R}^{2}$ da curva “média” $(\mathrm{M})$ de calibração ficou próximo de 1 e este também se aproximou do valor do coeficiente de correlação teórico concernente a curva (T) exposta na Figura 5.3 (B), obtida por Lewandowski e Beyenal (2006). 

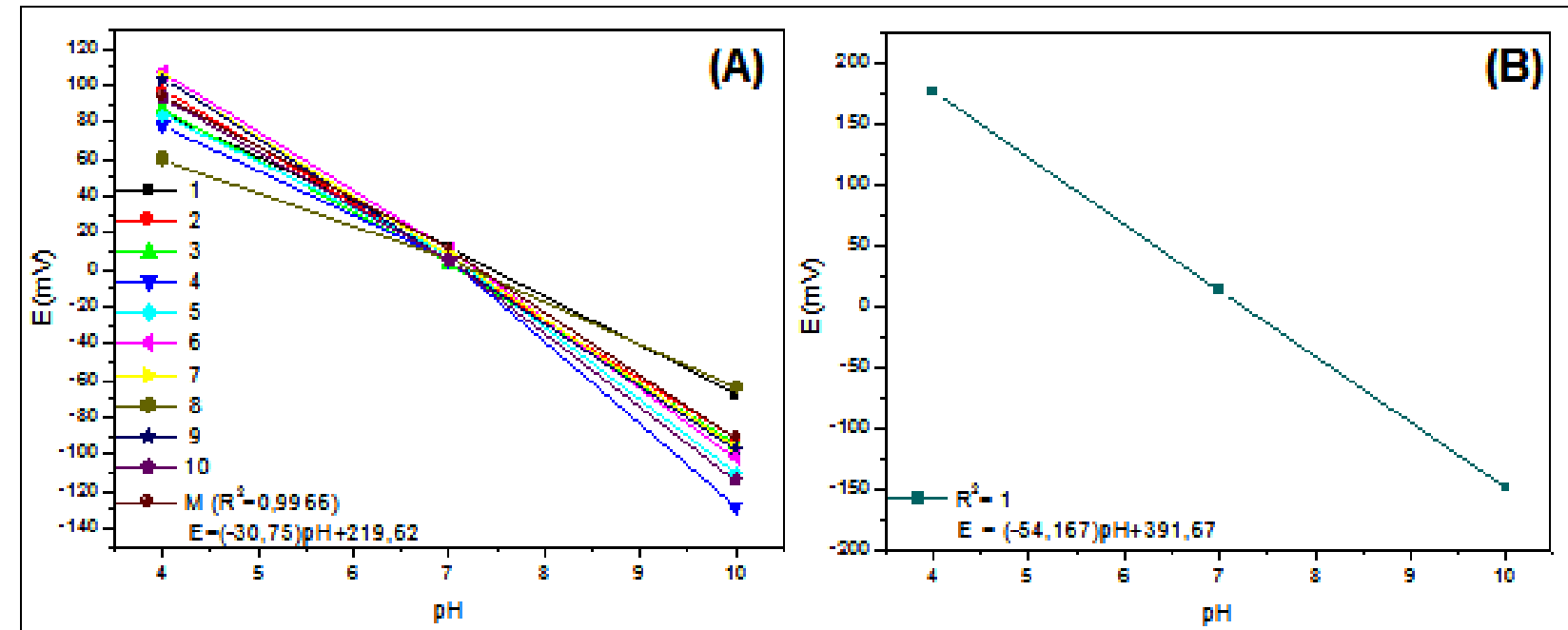

Figura 5. 3: (A) Curvas de calibração de dez microssensores de $p H$ e curva média das mesmas $\left(R^{2}=0,9966\right)$ $\left(T=25 \pm 2^{\circ} \mathrm{C}\right)$. (B) Curva de calibração teórica de um microssensor de $p H\left(R^{2}=1\right)$ (Fonte: LEWANDOWSKI; BEYENAL, 2006).

$\mathrm{Na}$ Figura 5.4 constam outras dez curvas de calibração de microeletrodos de $\mathrm{pH}$ obtidas e a curva média das mesmas. Pode ser observado, pelo $\mathrm{R}^{2}$ da curva média $(\mathrm{M})$, que essas se afastaram da curva teórica apresentada da Figura 5.3 (B).

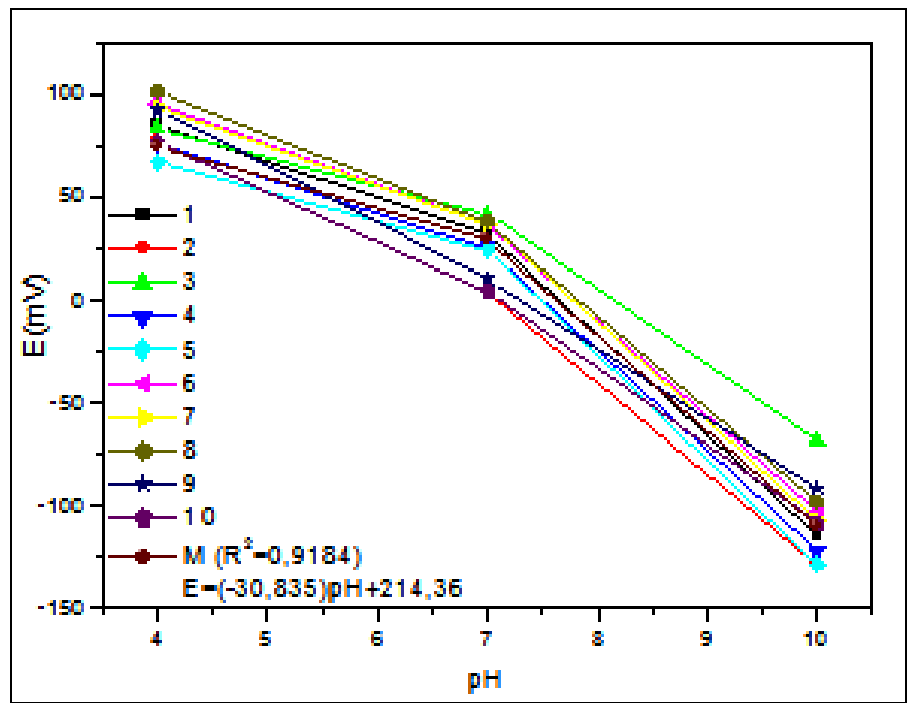

Figura 5. 4: Curvas de calibração com desvios de potencial de dez microssensores de pH e curva média das mesmas $\left(R^{2}=0,9184\right)\left(T=25 \pm 2^{\circ} \mathrm{C}\right)$.

Tal fenômeno pode ter ocorrido devido a uma conjunção de fatores que influenciam no desempenho apropriado de microeletrodos. Dentre esses se incluem a qualidade do processo de silanização das micropipetas utilizadas como compartimento externo dos microssensores, as condições de armazenamento das mesmas, o diâmetro da ponta sensível dos microeletrodos e o tempo de vida dos mesmos. 
Se as micropipetas de vidro foram silanizadas de forma imprópria, as membranas íon seletivas de $\mathrm{pH}$ podem ter se aderido fracamente ao vidro das mesmas e de maneira irregular, prejudicando o desempenho dos microssensores.

Outra conseqüência da má silanização das pipetas consiste na obtenção de membranas "curtas", ou seja, com comprimento inferior ao ideal $(50 \mu \mathrm{m})$. Quando membranas com pequenos comprimentos foram introduzidas em pipetas com diâmetros internos maiores que $30 \mu \mathrm{m}$, o escape das mesmas das micropipetas em período de tempo curto ( 5 dias) foi observado.

Assim, presumiu-se que o baixo valor do coeficiente de correlação $\left(\mathrm{R}^{2}\right)$ da curva de calibração média (M) apresentada na Figura 5.4 foi consequência de falhas nos procedimentos de fabricação dos microssensores aplicados na obtenção da mesma.

\subsection{3- Microssensores de íons amônio $\left(\mathrm{NH}_{4}{ }^{+}\right)$}

Na Figura 5.5 são expostas dez curvas de calibração obtidas com microssensores de detecção de íons amônio. $\mathrm{O}$ valor do $\mathrm{R}^{2}$ da curva média (M) dessas apresentou valor próximo de $1(0,9908)$. Mediante essas curvas de calibração foi possível verificar pequena variação dos valores de potencial para as concentrações de $10^{-6} \mathrm{~mol} / \mathrm{L}$ de íons amônio. Tal fato indicou que o limite de detecção médio desses microssensores de amônio era igual a $10^{-5} \mathrm{~mol} / \mathrm{L}$, e que concentrações inferiores a essa acarretariam em desvios da curva média $(\mathrm{M})$.

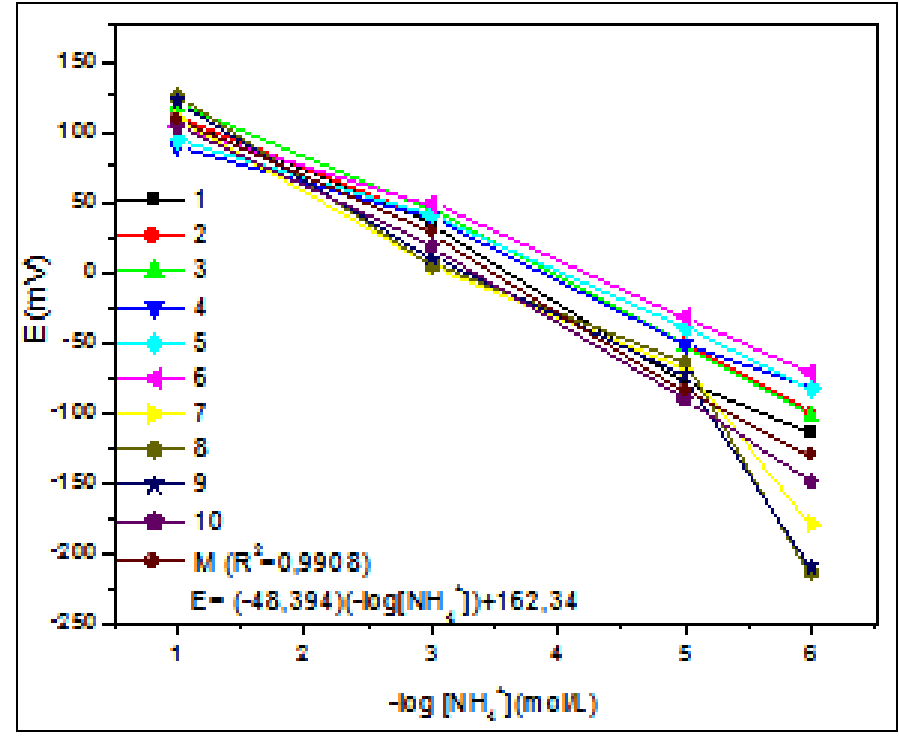

Tabela 5. 1: Equivalência de Unidades.

\begin{tabular}{|c|c|}
\hline$\left[\mathrm{NH}_{4}{ }^{+}\right](\mathrm{mol} / \mathrm{L})$ & {$\left[\mathrm{NH}_{4}{ }^{+}\right](\mathrm{mg} / \mathrm{L})$} \\
\hline $10^{-1}$ & 1800 \\
\hline $10^{-3}$ & 18 \\
\hline $10^{-5}$ & 0,18 \\
\hline
\end{tabular}

Figura 5. 5: Curvas de calibração de dez microssensores de $\mathrm{NH}_{4}{ }^{+}$ e curva média das mesmas $\left(R^{2}=0,9908\right)\left(T=25 \pm 2^{\circ} \mathrm{C}\right)$. 
Na Figura 5.6, curvas de calibração obtidas mediante a aplicação de microssensores de íons amônio, nas quais desvios de potencial (E) foram verificados, são apresentadas. A partir dessas confirmou-se o constatado na Figura 5.5, referente ao desvio das curvas de calibração. Assim, se esses microssensores fossem utilizados na detecção da concentração de íons amônio em amostras mais diluídas do que $10^{-5} \mathrm{~mol} \mathrm{NH}_{4}^{+} / \mathrm{L}$, concentrações imprecisas desses íons poderiam ser obtidas.

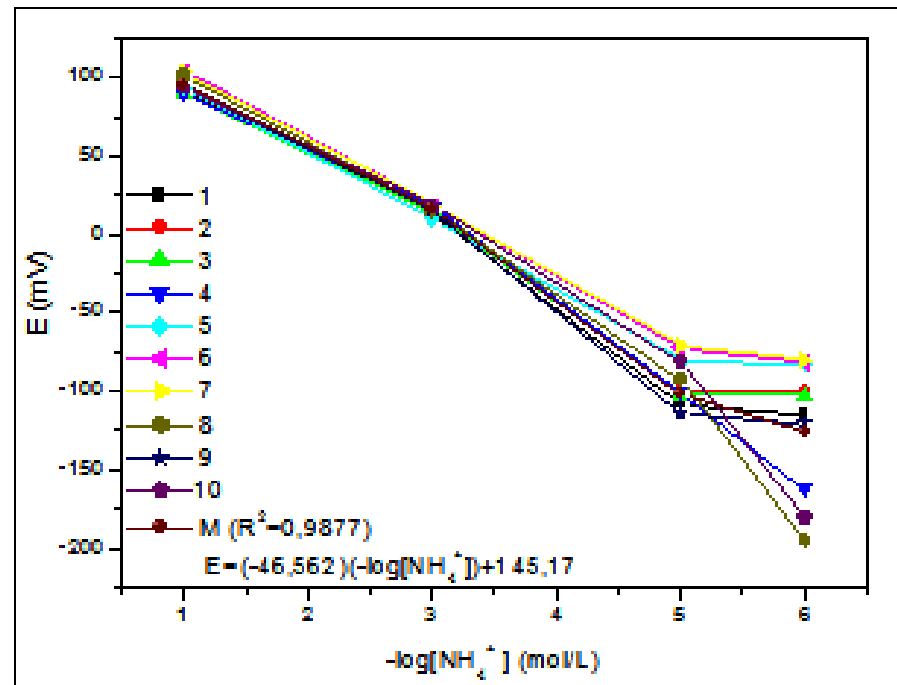

Figura 5. 6: Curvas de calibração com desvios de potencial de dez microssensores de $\mathrm{NH}_{4}^{+}$e curva média das mesmas $\left(R^{2}=0,9877\right)\left(T=25 \pm 2^{\circ} \mathrm{C}\right)$.

\subsection{4- Microssensores de íon nitrato $\left(\mathrm{NO}_{3}{ }^{-}\right)$}

As curvas de calibração de dez microssensores de íons nitrato e a curva média dos mesmos estão apresentadas na Figura 5.7.

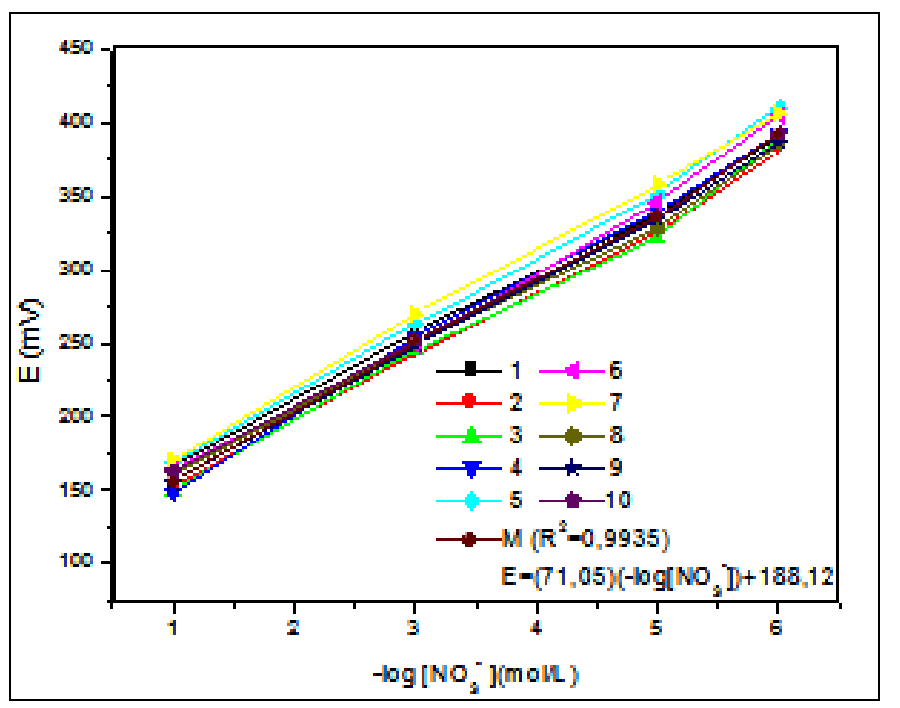

Tabela 5. 2: Equivalência de Unidades.

\begin{tabular}{|c|c|}
\hline$\left[\mathrm{NO}_{3}{ }^{-}\right](\mathrm{mol} / \mathrm{L})$ & {$\left[\mathrm{NO}_{3}{ }^{-}\right](\mathrm{mg} / \mathrm{L})$} \\
\hline $10^{-1}$ & 6200 \\
\hline $10^{-3}$ & 62 \\
\hline $10^{-5}$ & 0,62 \\
\hline
\end{tabular}

Figura 5. 7: Curvas de calibração de dez microssensores de $\mathrm{NO}_{3}^{-}$ e curva média das mesmas $\left(R^{2}=0,9935\right)\left(T=25 \pm 2^{\circ} \mathrm{C}\right)$. 
Foi verificado em tal Figura um alto coeficiente de correlação médio das curvas, de valor igual a 0,9935, fator indicativo de que existia alta dependência entre as concentrações de íons nitrato e os potenciais medidos e que portanto esses dispositivos podiam ser considerados como sensíveis ao analito em questão. Identificaram-se pequenos desvios nas curvas quando concentrações inferiores a $10^{-5}$ mol $\mathrm{NO}_{3}{ }^{-} / \mathrm{L}$ foram mensuradas.

De forma semelhante aos microssensores de íons amônio, os microssensores de íons nitrato demonstraram valores de potencial imprecisos quando submetidos a concentrações de íons nitrato inferiores a $10^{-5} \mathrm{~mol} \mathrm{NO}_{3}^{-} / \mathrm{L}$ (Figura 5.8). Foi determinado então, que o limite de detecção dos microssensores de íons nitrato é igual a $10^{-5} \mathrm{~mol} \mathrm{NO}_{3}{ }^{-} / \mathrm{L}$.

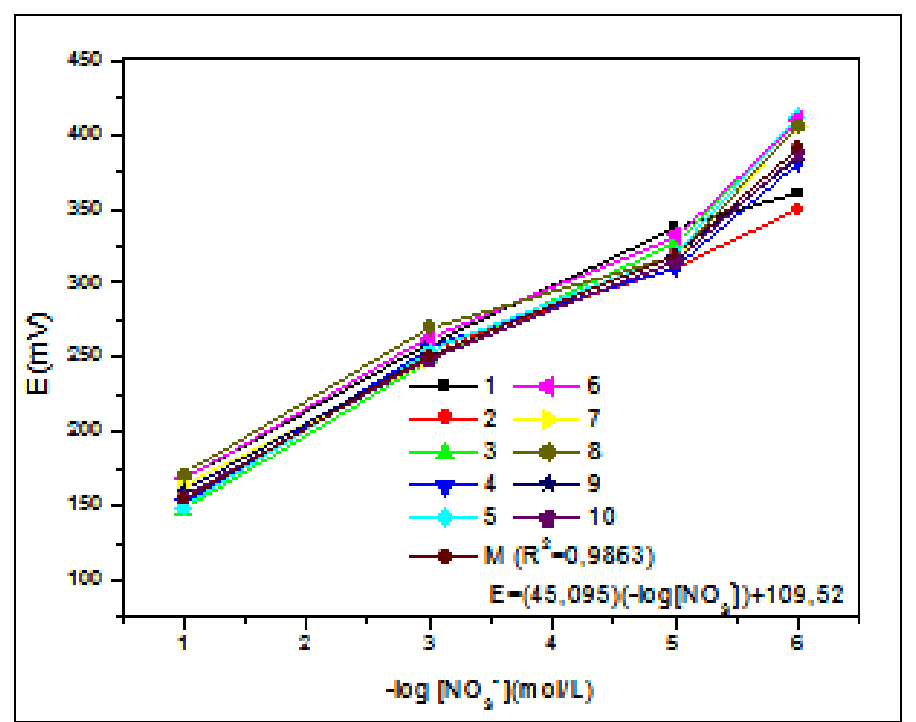

Figura 5. 8: Curvas de calibração com desvios de pontecial de dez microssensores de $\mathrm{NO}_{3}{ }^{-}$e curva média das mesmas $\left(R^{2}=0,9863\right)\left(T=25 \pm 2^{\circ} \mathrm{C}\right)$.

\subsection{5- Microssensores de $\mathrm{H}_{2} \mathrm{~S}$}

De acordo com Kuhl et al. (1998), os valores das concentrações das soluções de $\mathrm{H}_{2} \mathrm{~S}$ dissolvido adequadas, para que calibrações eficientes dos microssensores da espécie em questão fossem realizadas, deveriam se situar dentro de intervalo de 0 a $120 \mu \mathrm{mol} / \mathrm{L}$, o qual equivale a uma faixa de 0 a 3,4 mg/L. Contudo, a obtenção e posterior determinação de soluções com concentrações de $\mathrm{H}_{2} \mathrm{~S}$ distribuídas dentro desse intervalo não foram passíveis de realização, visto que o método utilizado para investigação das concentrações de tais soluções possuía limite de detecção de $800 \mu \mathrm{g} / \mathrm{L}$.

Assim sendo, soluções diluídas de $\mathrm{H}_{2} \mathrm{~S}$ com concentrações que se situaram dentro do intervalo de 0 a $25 \mu \mathrm{mol} / \mathrm{L}$ foram obtidas, pois concentrações superiores a essa última ultrapassaram a amplitude de detecção do método empregado para verificação das mesmas. 
Para obtenção das curvas de calibração de tais microssensores, o equilíbrio protolítico do gás $\mathrm{H}_{2} \mathrm{~S}$ foi levado em consideração. Como as soluções obtidas do gás dissolvido apresentaram pH menor do que 5 consideraram-se apenas o primeiro equilíbrio protolítico do mesmo (Equações 5.1 e 5.2) e a concentração de $\mathrm{S}^{2-}{ }_{\text {total }}$ foi obtida através da Equação 5.3.

$$
\begin{gathered}
\mathrm{H}_{2} \mathrm{~S}+\mathrm{H}_{2} \mathrm{O} \rightleftarrows \mathrm{HS}^{-}+\mathrm{H}_{3} \mathrm{O}^{+} \\
K_{1}=\frac{\left[H S^{-}\right] \cdot\left[H_{3} O^{+}\right]}{\left[H_{2} S\right]} \\
{\left[H_{2} S\right]=\frac{\left[S_{t o t}^{2-}\right]}{\left(1+\frac{K_{1}}{\left[H_{3} O^{+}\right]}\right)}}
\end{gathered}
$$

Por meio do uso das Equações 5.1 e 5.2, primeiramente determinou-se a concentração de $\mathrm{H}_{2} \mathrm{~S}$ de cada solução do gás utilizada para construção das curvas de calibração, a partir do valor da constante de equilíbrio $\left(\mathrm{K}_{1}\right)$, do $\mathrm{pH}$ (medido concomitantemente a calibração mediante o uso de pHmetro) e da concentração mensurada de íons bissulfeto $\left(\mathrm{HS}^{-}\right)$das mesmas. As concentrações de $\mathrm{S}^{2-}$ tot foram então determinadas, utilizando-se a Equação 5.3, e plotadas contra os sinais de corrente detectados pelos microssensores.

Foram realizadas apenas duas calibrações com dois microssensores de $\mathrm{H}_{2} \mathrm{~S}$. As curvas obtidas como resultados dessas calibrações encontram-se na Figura 5.9. Na Figura 5.10, está presente uma curva de calibração teórica obtida por Jeroschewski, Steuckart e Kuhl (1996) por meio da aplicação de microssensor de $\mathrm{H}_{2} \mathrm{~S}$.

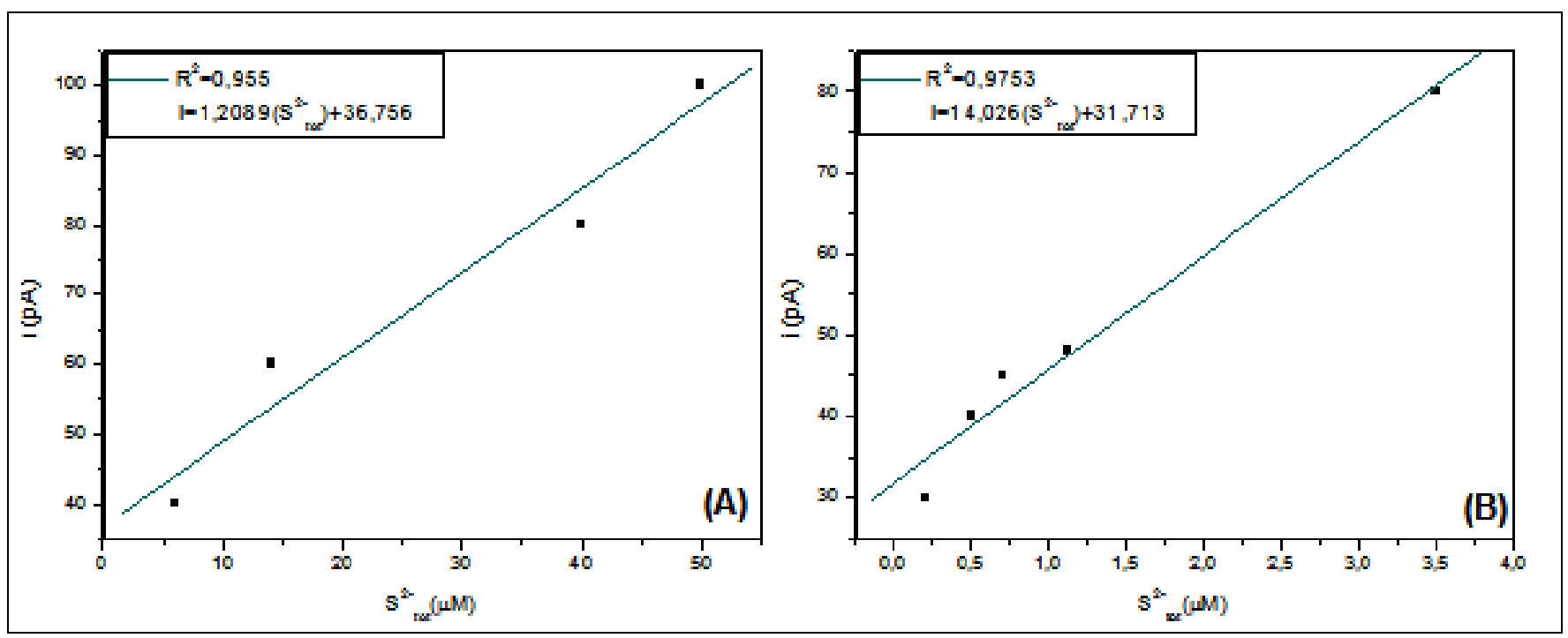

Figura 5. 9: Curvas de calibração obtidas mediante uso de dois microssensores de $\mathrm{H}_{2} \mathrm{~S}\left(\mathrm{~T}=25 \pm 2^{\circ} \mathrm{C}\right)$. 


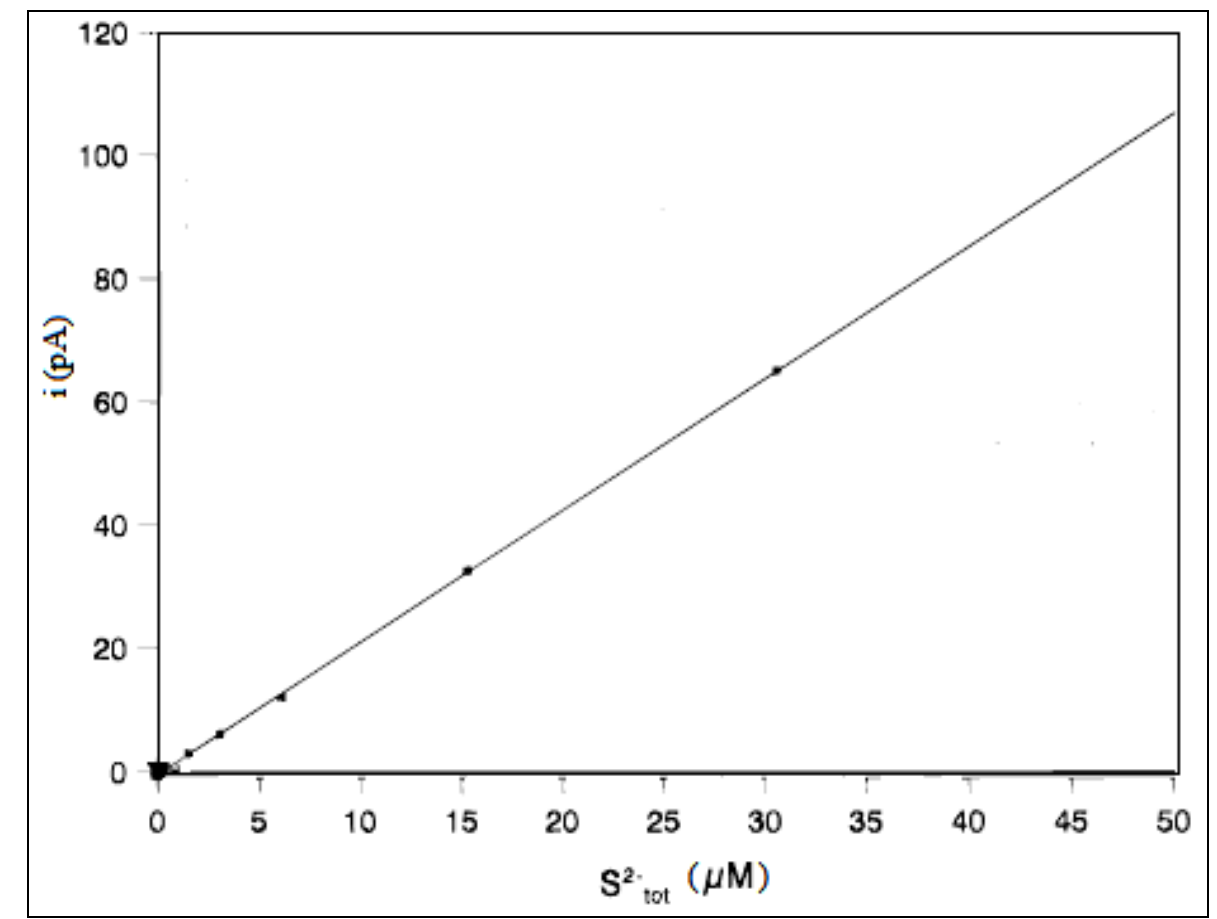

Figura 5. 10: Curva de calibração teórica de microssensores de $\mathrm{H}_{2} \mathrm{~S}$ (Fonte: JEROSCHEWSKI et al.,1996).

A partir das Figuras 5.9 e 5.10, foi notado que as curvas de calibração obtidas apresentaram coeficientes de correlação com valores elevados, indicando relação linear entre as correntes geradas pelos microssensores e as concentrações de $\mathrm{S}^{2-}$ tot presentes nas amostras. Foi notado também que a curva de calibração (A) apresentada na Figura 5.9 assemelhou-se a curva de calibração teórica, presente na Figura 5.10. Já na curva de calibração (B) observou-se que os valores dos sinais de correntes gerados pelo microssensor para soluções aquosas com baixas concentrações de $\mathrm{H}_{2} \mathrm{~S}$ foram superiores aos da curva de calibração teórica.

Foi suposto que tais incoerências relacionadas aos valores de corrente foram devidas a pequenos erros na construção dos microssensores de $\mathrm{H}_{2} \mathrm{~S}$, pois a introdução dos três eletrodos no interior dos compartimentos externos desses microssensores (Figura 5.11) consistiu em etapa complexa da manufatura dos mesmos. O posicionamento exato dos eletrodos no interior dos microssensores de $\mathrm{H}_{2} \mathrm{~S}$ consiste em condição importante para que o funcionamento desses microssensores não seja alterado pela formação de precipitados de sulfeto de platina $\left(\mathrm{PtS}_{2}\right)$ na superfície do eletrodo de trabalho devido à proximidade deste à membrana (KAPUSKA ${ }^{12}$ et al., 1983 apud JEROSCHEWSKI et al., 1998).

\footnotetext{
${ }^{12}$ KAPUSKA, S.; VIEHBECK, A.; WILHELM, S.S.; HACKERMAN, N. (1983). The anodic oxidation of sulfide on platinum electrodes. J. Eletroanal Chem, v.153, p.157-174.
} 


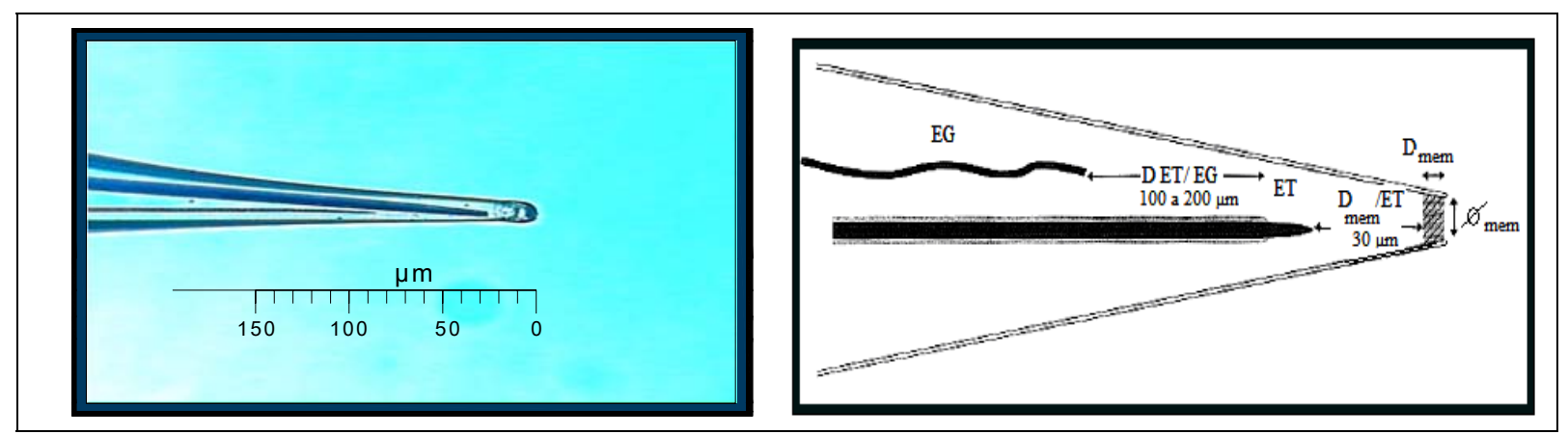

Figura 5. 11: Microssensores de $\mathrm{H}_{2} \mathrm{~S}$ construído e aplicado (esquerda) e do microssensor de $\mathrm{H}_{2} \mathrm{~S}$ ideal (direita).

Conforme foi observado na Figura 5.11, a distância entre o eletrodo de trabalho (ET) e a membrana de silicone apresentou magnitude menor do que $20 \mu \mathrm{m}$, a qual foi inferior a adequada (30 $\mu \mathrm{m})$ para esse tipo de microssensor. O distanciamento entre o eletrodo de trabalho e o eletrodo de guarda (EG) deveria ser de 100 a $200 \mu \mathrm{m}$ para que o microeletrodo apresentasse bom desempenho, contudo a distância entre tais eletrodos no microssensor de $\mathrm{H}_{2} \mathrm{~S}$ construído foi de $60 \mu \mathrm{m}$. Assim, atribuiu-se a obtenção de altos valores de sinais de corrente devido aos erros no posicionamento dos eletrodos no interior do microssensor em questão.

\section{2- Testes}

\subsection{1- Eletrodos de Ag/AgCl clorinizados}

Conforme detalhado na Seção 4.3.1, um microssensor contendo dois eletrodos de $\mathrm{Ag} / \mathrm{AgCl}$, um obtido por eletrodeposição e o outro por clorinização, foi submetido a alguns testes a fim de se verificar a durabilidade e funcionamento dos dois eletrodos em um período de tempo de três meses . Os resultados obtidos relacionados, tanto à estabilidade das mensurações de OD quanto ao tempo de resposta proporcionados por ambos os eletrodos, são mostrados nos gráficos presentes na Figura 5.12. 

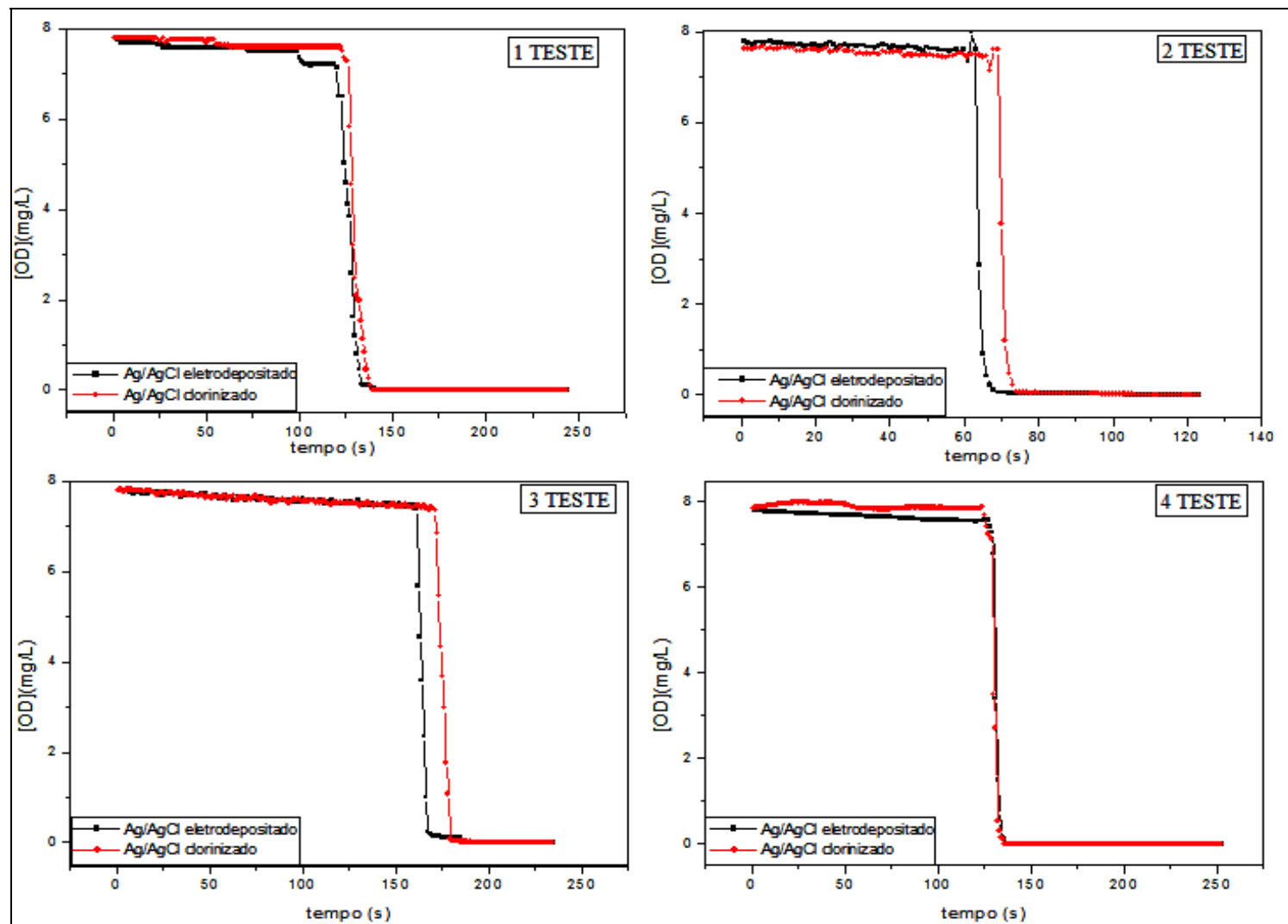

Figura 5. 12: Gráficos das concentrações de OD obtidos nos testes dos dois tipos de eletrodos de $\mathrm{Ag} / \mathrm{AgCl} \mathrm{em}$ função de tempo $\left(T=25 \pm 2^{\circ} \mathrm{C}\right)$.

Observando-se tais gráficos constatou-se que ambos os tipos de eletrodos de $\mathrm{Ag} / \mathrm{AgCl}$ promoveram comportamentos bastante semelhantes, relacionados à estabilidade e tempo de resposta (inferior a $1 \mathrm{~s}$ ) do microssensor no qual os mesmos foram inseridos, no transcorrer dos três meses.

Foram identificadas também, para os dois tipos de eletrodos, quedas dos sinais de corrente (da ordem de 2 a 10 pA) nas duas condições de calibração (água saturada com oxigênio e com nitrogênio). Tais quedas foram provavelmente devidas a alterações das propriedades físicas iniciais dos eletrodos de trabalho de $\mathrm{Ag} / \mathrm{AgCl}$, como a perda de condutividade do mesmo oriunda da exposição do sensor a temperaturas elevadas $\left(>25{ }^{\circ} \mathrm{C}\right)$, ou como a mudança das características de suas superfícies, proporcionadas pela reações ocorridas nas mesmas.

No decorrer de apenas três meses não foi possível verificar a deterioração do eletrodo de $\mathrm{Ag} / \mathrm{AgCl}$, obtido por eletrodeposição, conforme explanado na Seção 4.3.1. Concluiu-se então que a degradação dos eletrodos eletrodepositados de $\mathrm{Ag} / \mathrm{AgCl}$, a qual varia também de acordo com a tensão e o tempo empregados no processo de eletrodeposição para obtenção dos mesmos, ocorre em período de tempo superior ao de três meses. 


\subsection{2- Teste de seletividade dos microssensores de $\mathrm{pH}, \mathrm{NO}_{3}{ }^{-}$e $\mathrm{NH}_{4}{ }^{+}$}

Como resultados dos testes de seletividades dos microssensores potenciométricos de detecção de íons amônio foram encontrados os seguintes coeficientes de seletividade ( $\left.\mathrm{K}_{A, B}^{P O T}\right)$ (Tabela 5.3).

Tabela 5. 3: Valores de $\mathrm{K}_{A, B}^{P O T}$ obtidos e teóricos para as espécies interferentes de microssensores de $\mathrm{NH}_{4}^{+}$.

\begin{tabular}{|c|c|c|}
\hline \multicolumn{3}{|c|}{$\mathbf{N H}_{\mathbf{4}}{ }^{+}$- Íon primário (A) } \\
\hline \hline Íon interferente (B) & $\mathrm{K}_{A, B}^{P O T}$ obtido & $\mathrm{K}_{A, B}^{P O T}$ teórico \\
\hline $\mathrm{K}^{+}$ & $1,59 \cdot 10^{-2}$ & $1,90.10^{-2}$ \\
\hline $\mathrm{Na}^{+}$ & $1,58.10^{-3}$ & $5,00 \cdot 10^{-3}$ \\
\hline $\mathrm{H}^{+}$ & $1,00.10^{-5}$ & $1,99.10^{-5}$ \\
\hline
\end{tabular}

De acordo com o principio do Método de determinação de coeficiente de seletividade empregado, quanto mais próximo de 1 for $\mathrm{K}_{A, B}^{P O T}$ obtido, maior será a interferência causada pela espécie B. Por meio da Tabela 5.3, pôde ser verificado que os valores dos $\mathrm{K}_{A, B}^{P O T}$ obtidos não se aproximaram da unidade e que os mesmos possuíram a mesma ordem de grandeza dos valores teóricos. Assim, os microssensores de íons amônio puderam ser considerados como seletivos aos seus analitos (ou íons primários $-\mathrm{NH}_{4}{ }^{+}$).

Quando tal teste de seletividade foi feito com o intuito de verificar se o microssensor de $\mathrm{pH}$ estava suscetível a interferências promovidas pelas espécies B, os resultados apresentados na Tabela 5.4 foram encontrados.

Tabela 5. 4: Valores de $\mathrm{K}_{A, B}^{P O T}$ obtidos e teóricos para as espécies interferentes de microssensores de pH.

\begin{tabular}{|c|c|c|}
\hline \multicolumn{3}{|c|}{$\mathbf{H}^{+}$- Íon primário (A) } \\
\hline \hline Íon interferente (B) & $\mathrm{K}_{A, B}^{P O T}$ obtido & $\mathrm{K}_{A, B}^{P O T}$ teórico \\
\hline $\mathrm{K}^{+}$ & $4,00.10^{-8}$ & $3,98.10^{-5}$ \\
\hline $\mathrm{Na}^{+}$ & $3,16.10^{-7}$ & $2,51.10^{-6}$ \\
\hline $\mathrm{Li}^{+}$ & $1,00.10^{-8}$ & $1,25.10^{-7}$ \\
\hline
\end{tabular}

Verificou-se que baixos valores de $\mathrm{K}_{A, B}^{P O T}$ foram obtidos, contudo foi notado que esses diferiram dos valores dos coeficientes de seletividade teóricos. As diferenças dos valores dos $\mathrm{K}_{A, B}^{P O T}$ teóricos e obtidos foram atribuídas ao fato de que o método utilizado para determinação dos coeficientes não consistiu no mesmo empregado para obtenção dos coeficientes teóricos. A partir dos coeficientes de seletividades encontrados, verificou-se que os microssensores de $\mathrm{pH}$ não eram passíveis de sofrer interferências em suas medições devido à presença de tais íons em amostras complexas e que consequentemente, esses eram seletivos a íons $\mathrm{H}^{+}$somente. 
Abordando-se agora o teste de seletividade feito para os microssensores de detecção de íons nitrato tem-se que os resultados presentes na Tabela 5.5 foram alcançados.

Tabela 5. 5: Valores de $\mathrm{K}_{A, B}^{P O T}$ obtidos e teóricos para as espécies interferentes de microssensores de $\mathrm{NO}_{3}{ }^{-}$.

\begin{tabular}{|c|c|c|}
\hline \multicolumn{3}{|c|}{$\mathbf{N O}_{\mathbf{3}}{ }^{-}$- Íon primário (A) } \\
\hline \hline Íon interferente (B) & $\mathrm{K}_{A, B}^{P O T}$ obtido & $\mathrm{K}_{A, B}^{P O T}$ teórico \\
\hline $\mathrm{Cl}^{-}$ & $1,00 \cdot 10^{-5}$ & $3,16 \cdot 10^{-5}$ \\
\hline $\mathrm{NO}_{2}^{-}$ & $9,97 \cdot 10^{-1}$ & $3,16 \cdot 10^{-4}$ \\
\hline $\mathrm{HCO}_{3}^{-}$ & $1,90.10^{-4}$ & $1,00 \cdot 10^{-4}$ \\
\hline
\end{tabular}

Notou-se que o valor do $\mathrm{K}_{A, B}^{P O T}$ obtido, quando os íons nitrito $\left(\mathrm{NO}_{2}^{-}\right)$foram testados como espécies interferentes, foi muito superior ao teórico e que este apresentou valor muito alto (próximo de 1), indicando que o microssensor de íons nitrato não era seletivo ao seu analito $\left(\mathrm{NO}_{3}{ }^{-}\right)$e que o mesmo respondia igualmente aos íons nitrato e aos íons nitrito.

Para melhor visualização do fenômeno descrito anteriormente os potenciais (E) obtidos quando os microssensores de íons nitrato foram submetidos tanto a soluções que continham apenas íons nitrito quanto a soluções que possuíam somente íons nitrato, nas mesmas concentrações que as de nitrito, foram representados no gráfico exibido na Figura 5.13:

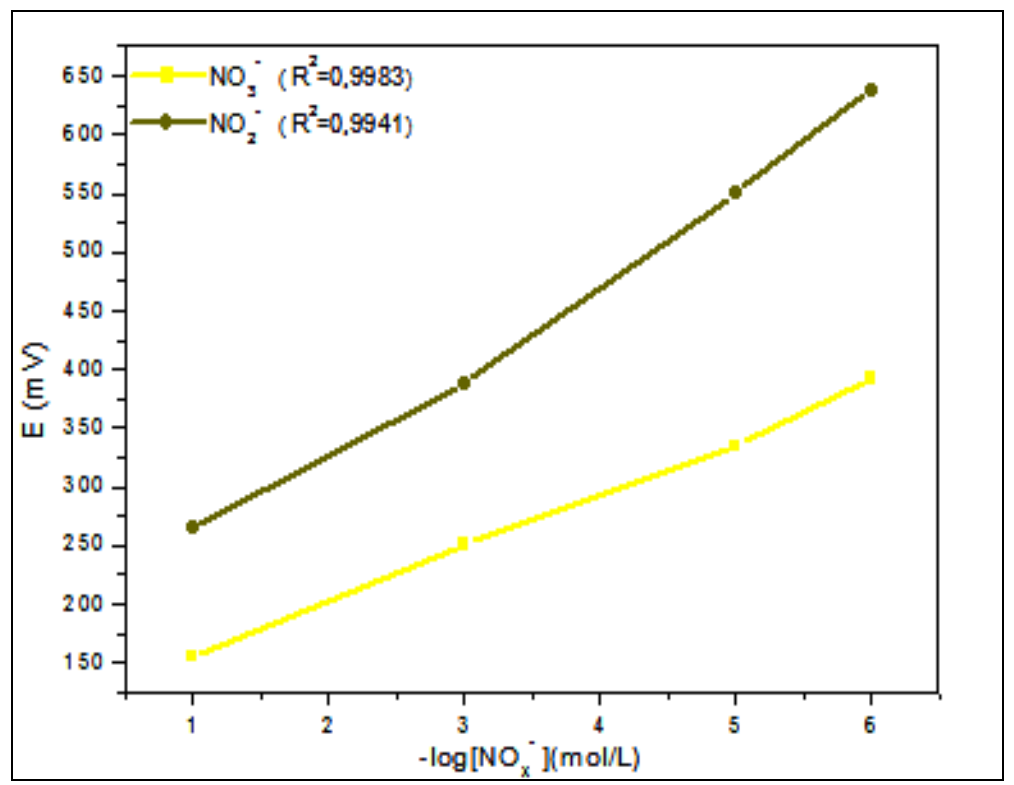

Figura 5. 13: Gráfico do teste de seletividade dos microssensores de íons nitrato $\left(\mathrm{T}=25 \pm 2^{\circ} \mathrm{C}\right)$.

Verificou-se, portanto, que os valores dos potenciais alcançados mediante aplicação dos microssensores de íons nitrato em soluções diluídas que continham somente $\mathrm{NO}_{2}^{-}$, constaram de aproximadamente o dobro dos mesmos obtidos em soluções diluídas de nitrato. 
Assim, em dado momento da presente pesquisa quando a detecção de ambos os íons em questão foi confirmada, os microssensores de íons nitrato passaram a ser denominados como microeletrodos para íons $\mathrm{NO}_{\mathrm{x}}^{-}$.

Algumas tentativas concernentes ao aumento da seletividade desses microssensores foram feitas a fim de se eliminar as interferências causadas pelos íons nitrito. Essas consistiram na introdução do eletrólito tamponado em $\mathrm{pH}$ 8,5 e na retirada de ar da solução eletrolítica, técnicas propostas por Thomas (1978). Todavia, essas não foram eficientes e comprovou-se em experimentos que serão detalhados posteriormente que os microssensores de íons nitrato detectavam os íons $\mathrm{NO}_{3}{ }^{-}{\mathrm{e} \mathrm{NO}_{2}}^{-}$.

\section{3- Resultados das aplicações dos microssensores em biofilmes}

Os microperfis de concentração de $\mathrm{OD}, \mathrm{pH}$, íons $\mathrm{NO}_{3}{ }^{-}$e íons $\mathrm{NH}_{4}{ }^{+}$foram apresentados através de representação comumente adotada em análises de biofilmes mediante o uso de microssensores, na qual a superfície do biofilme situa-se na profundidade de $0 \mu \mathrm{m}$ e os valores negativos de profundidade referem-se ao meio líquido (bulk). Deste modo, conforme o microssensor atinge as zonas mais internas do biofilme os valores de profundidade (em $\mu \mathrm{m})$ aumentam.

Para se determinar o início do contato dos microssensores nos biofilmes, foi levada em consideração pesquisa realizada por Lewandowski e colaboradores (1991), os quais aplicaram em biofilmes microoptrodos de fibra óptica para determinação de densidade de amostras, conjuntamente com o emprego de microssensores de OD. A partir da sobreposição dos microperfis obtidos mediante a aplicação desses dois microssensores, os autores concluíram que o início do contato do microssensor de OD com o biofilme se dava no primeiro ponto de inflexão da curva da concentração de OD com a profundidade do biofilme.

A aquisição dos sinais de corrente e dos potencias elétricos gerados, os quais eram proporcionais às concentrações das variáveis distintas mensuradas mediante aplicação de microssensores amperométricos e potenciométricos, era feita até que os microssensores atingissem a superfície da célula de fluxo, na qual o biofilme encontrava-se aderido, e tal encontro (microssensor-superfície) causava a quebra da ponta sensível do microssensor. Tal quebra promovia a aparição de sinais de corrente e de potencias extremamente elevados e assim era possível verificar que o microssensor aplicado havia atingido as zonas mais profundas do biofilme que estava sendo analisado. Quando o relatado anteriormente ocorria, a análise do biofilme realizada mediante o uso de microssensores era finalizada. 


\subsection{1-Experimento 1}

Os microperfis de OD que foram obtidos nos quatro primeiros dias de operação da célula de fluxo encontram-se apresentados na Figura 5.14.
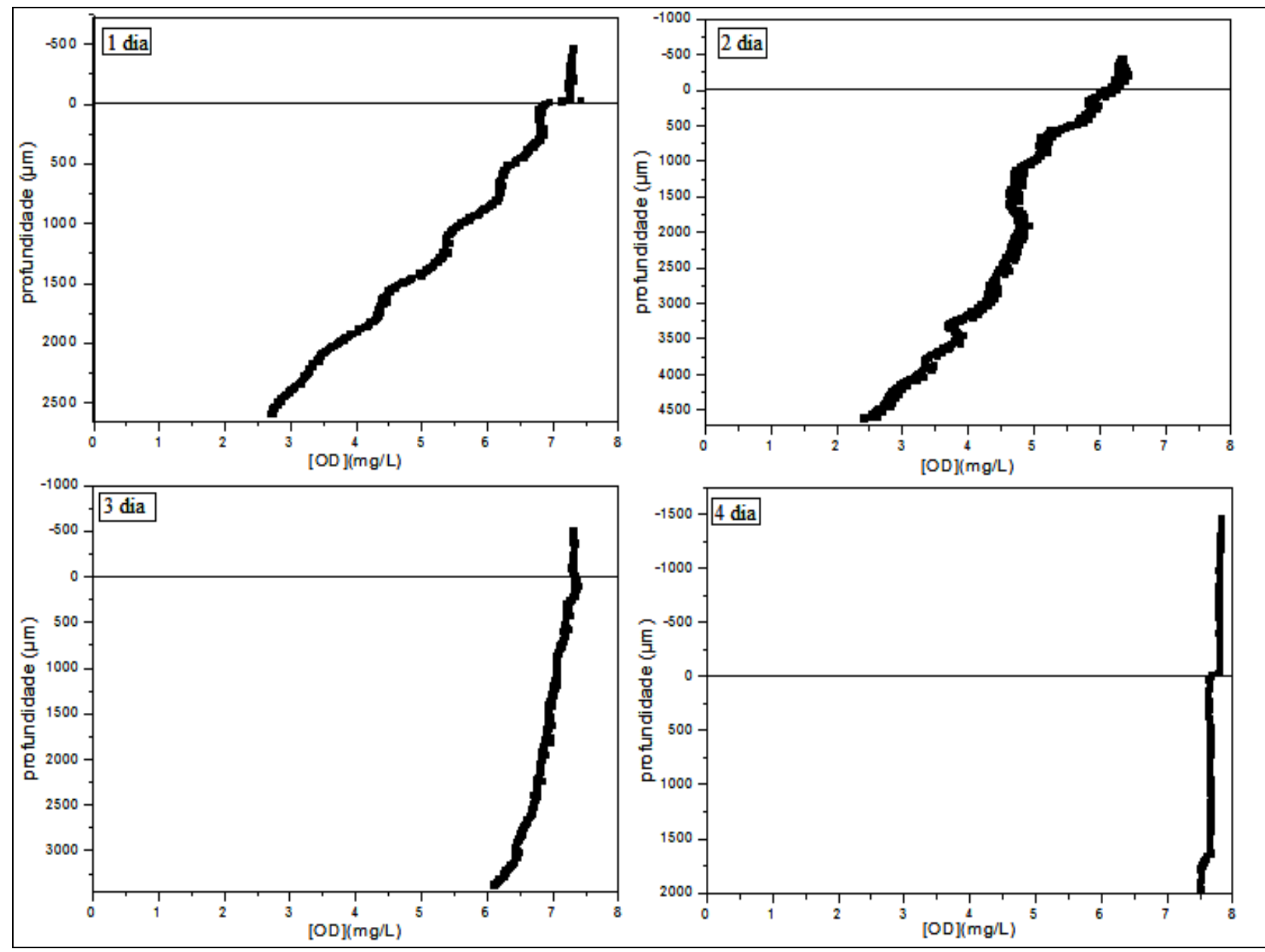

Figura 5. 14: Microperfis de $[O D]$ obtidos nos $1^{\circ}, 2^{\circ}, 3^{\circ}$ e $4^{\circ}$ dias do experimento

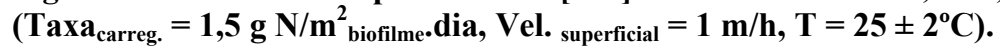

Primeiramente vale ressaltar que as aparentes inconsistências relativas à espessura dos biofilmes são devidas às estruturas irregulares que os mesmos possuem e ao fato de que infelizmente a introdução do microssensor de OD no mesmo ponto do aglomerado do biofilme (dia após dia) foi inexequível ao longo de todos os experimentos dessa pesquisa. De Beer et al. (1993) também observaram variação das espessuras em biofilmes menos espessos através do uso de microssensores de OD. Tais autores representaram o observado por meio da ilustração exposta em seguida (Figura 5.15). 


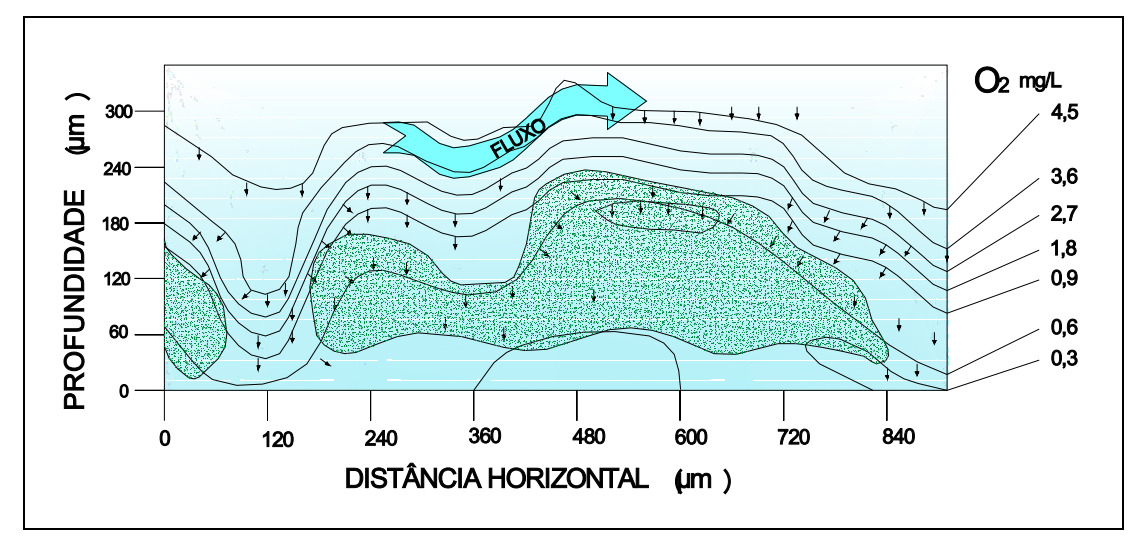

Figura 5. 15: Representação da variação das espessuras em biofilmes verificadas através do uso de microssensores de OD (Fonte: Adaptado de DE BEER et al., 1993).

Tratando-se, dos dois primeiros dias de operação da célula de fluxo, concentrações de OD no meio líquido que se situaram dentro da faixa de 6,5 a $7,0 \mathrm{mg} / \mathrm{L}$ foram detectadas, sendo que essas decaíram para aproximadamente $2,5 \mathrm{mg} / \mathrm{L}$ nas zonas mais profundas do biofilme as quais distavam de 2500 à $4400 \mu \mathrm{m}$ da superfície do mesmo.

Os fenômenos observados nesses dois primeiros dias do experimento não ocorreram no terceiro e no quarto dias do mesmo, nos quais se constatou que houve penetração do oxigênio em todas as camadas dos biofilmes, inclusive nas mais internas (próximas da superfície suporte) nas quais concentrações elevadas de OD foram detectadas: 6,1 $\mathrm{mg} / \mathrm{L}$ (terceiro dia) e 7,5 mg/L (quarto dia).

As micrografias dos biofilmes desenvolvidos nesses primeiros quatro dias do experimento encontram-se expostas na Figura 5.16. Bolhas de gases (marcadas com círculo vermelho) foram identificadas nos biofilmes formados nos dois primeiros dias. 


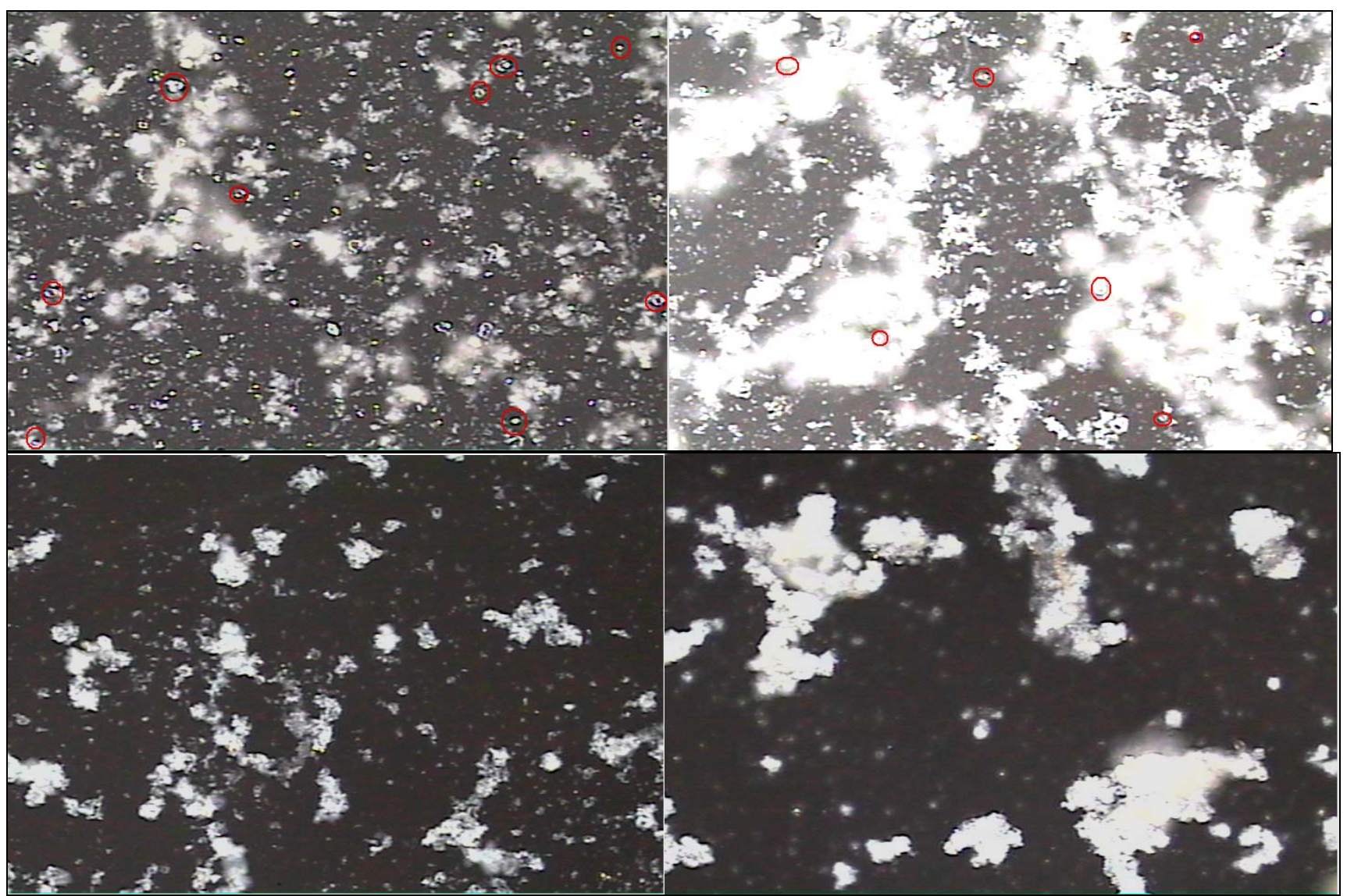

Figura 5. 16: Micrografias (aumento de $100 \mathrm{X}$ ) dos biofilmes no $1^{\circ}, 2^{\circ}$ (fotos superiores), $3^{\circ}$ e $4^{\circ}$ (fotos inferiores) dias do experimento (Taxa ${ }_{\text {carreg. }}=1,5 \mathrm{~g} \mathrm{~N} / \mathrm{m}^{2}{ }_{\text {biofilme.dia, Vel. } \text { superficial }}=1 \mathrm{~m} / \mathrm{h}$ ).

A formação de gases no interior de biofilmes foi associada à limitação de transferência de oxigênio nas camadas mais profundas dos mesmos, visto que esses atingiram espessuras de até 4400 $\mu \mathrm{m}$. Fato semelhante a esse foi relatado por Bryers (1988), o qual observou a formação de ácidos voláteis, com abaixamento do $\mathrm{pH}$ e produção de gases insolúveis em biofilme presente em sistema piloto de filme fixo usado para desnitrificação. $O$ autor atribuiu o enfraquecimento da estrutura do biofilme com posterior desprendimento localizado do mesmo à formação de bolhas de nitrogênio.

Analisando-se, conjuntamente, os microperfis de OD obtidos nesses quatros dias e somando-os as micrografias dos biofilmes formados em tal período foi estimado que o desenvolvimento avançado do biofilme nos dois primeiros dias e as baixas concentrações de OD detectadas em suas camadas mais internas, bem como aumento das concentrações de OD ao longo das espessuras dos biofilmes analisados no terceiro e quarto dia, foram decorrentes da alta taxa de carregamento de nitrogênio ao qual a célula de fluxo foi submetida.

A elevada disponibilidade de nutrientes consequente da taxa de carregamento de 1,5 $\mathrm{g}$ $\mathrm{N} / \mathrm{m}^{2}$ biofilme.dia (considerada como alta para o tamanho do reator de bancada utilizado) combinada com a 
baixa velocidade superficial adotada $(1 \mathrm{~m} / \mathrm{h})$ favoreceu o rápido desenvolvimento de microcolônias celulares no interior de biofilmes maduros, fazendo com que os mesmos se tornassem bastante espessos. Foi suposto que nas zonas mais internas dos biofilmes ocorreu a formação de gases que promoveu desprendimento dos mesmos de suas superfícies suporte.

O arraste desses fragmentos de biofilmes que se soltaram da superfície suporte (também denominada de substrato) foi evidenciado pelas concentrações de OD elevadas mensuradas no terceiro e quarto dia, quando o ciclo de formação do biofilme foi novamente iniciado, conforme pôde ser observado nas micrografias apresentadas na Figura 5.16.

No quinto dia após o início do experimento, duas microperfilações de OD no biofilme foram realizadas, uma no período da manhã e outra à tarde (Figura 5.17). Através dessas foi possível observar que as concentrações de OD medidas ao longo da espessura do biofilme no período da manhã foram bem superiores as detectadas no mesmo no período da tarde.
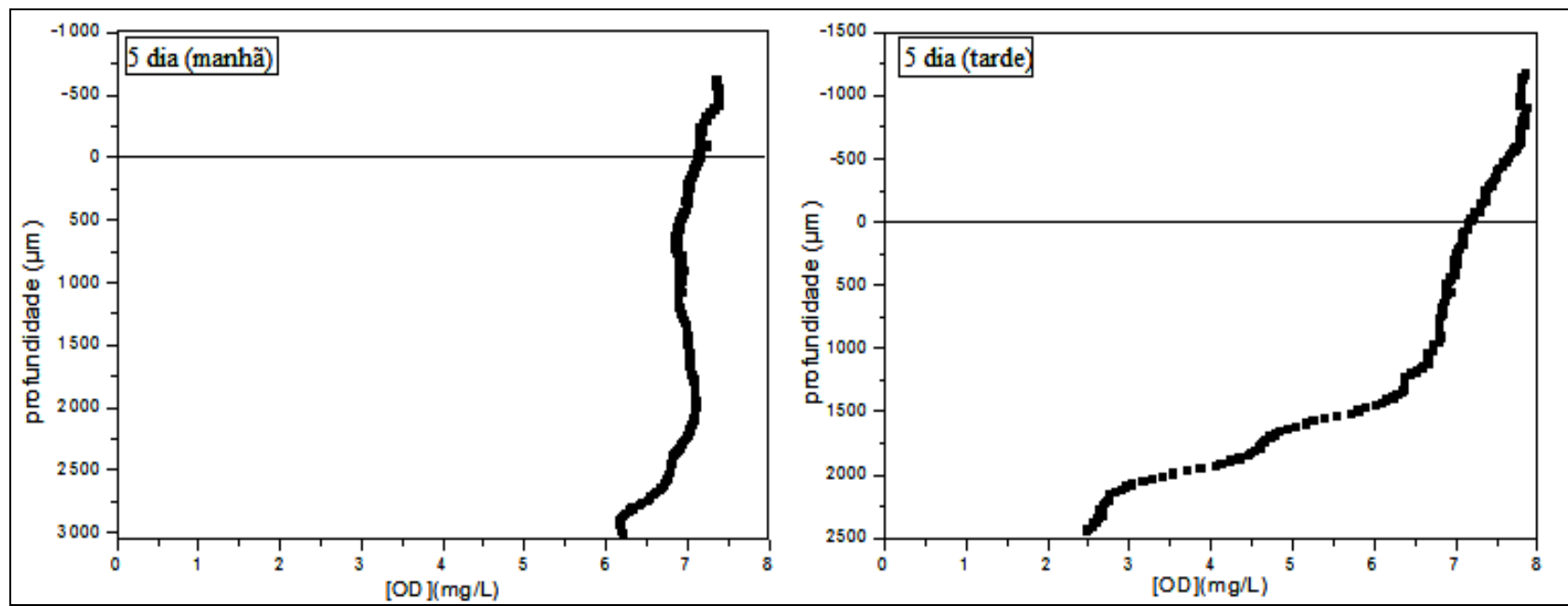

Figura 5. 17: Perfis de concentração de OD no $5^{0}$ dia do experimento (Taxa carreg. $=1,5 \mathrm{~g} \mathrm{~N} / \mathrm{m}^{2}{ }_{\text {biofilme.dia, }}$ Vel. superficial $=1 \mathrm{~m} / \mathrm{h}, \mathrm{T}=25 \pm 2^{\circ} \mathrm{C}$ ).

O fenômeno descrito (obtenção de perfis de concentração de OD distintos em um mesmo dia) pode ser explicado de duas maneiras, sendo a primeira delas a seguinte: como a taxa de carregamento de $1,5 \mathrm{~g} \mathrm{~N} / \mathrm{m}^{2}$ biofilme.dia e a velocidade superficial foram mantidas, o crescimento rápido do biofilme (período de tempo de 6 horas) foi novamente verificado, de modo que altas concentrações de OD foram mensuradas de manhã e baixas concentrações de OD nas zonas mais profundas do mesmo foram determinadas no período da tarde.

A outra justificativa para tal acontecimento recai no ato de introdução dos microssensores no biofilme para mensuração de OD no interior do mesmo. Devido ao fato de que biofilmes possuem 
estruturas complexas e não-uniformes, os microssensores podem ter sido introduzidos em um dos “canais" do biofilme no período da manhã e no interior de um aglomerado no período da tarde.

No decorrer do penúltimo dia do experimento foram mensuradas baixas concentrações de OD nas camadas mais internas dos biofilmes (tanto no perfil obtido no período da manhã quanto no da tarde), conforme exposto na Figura 5.18. Na mesma figura encontra-se presente o microperfil de OD do último dia do experimento, no qual as concentrações de OD nas zonas mais profundas do biofilme chegaram a atingir valores próximos de zero.

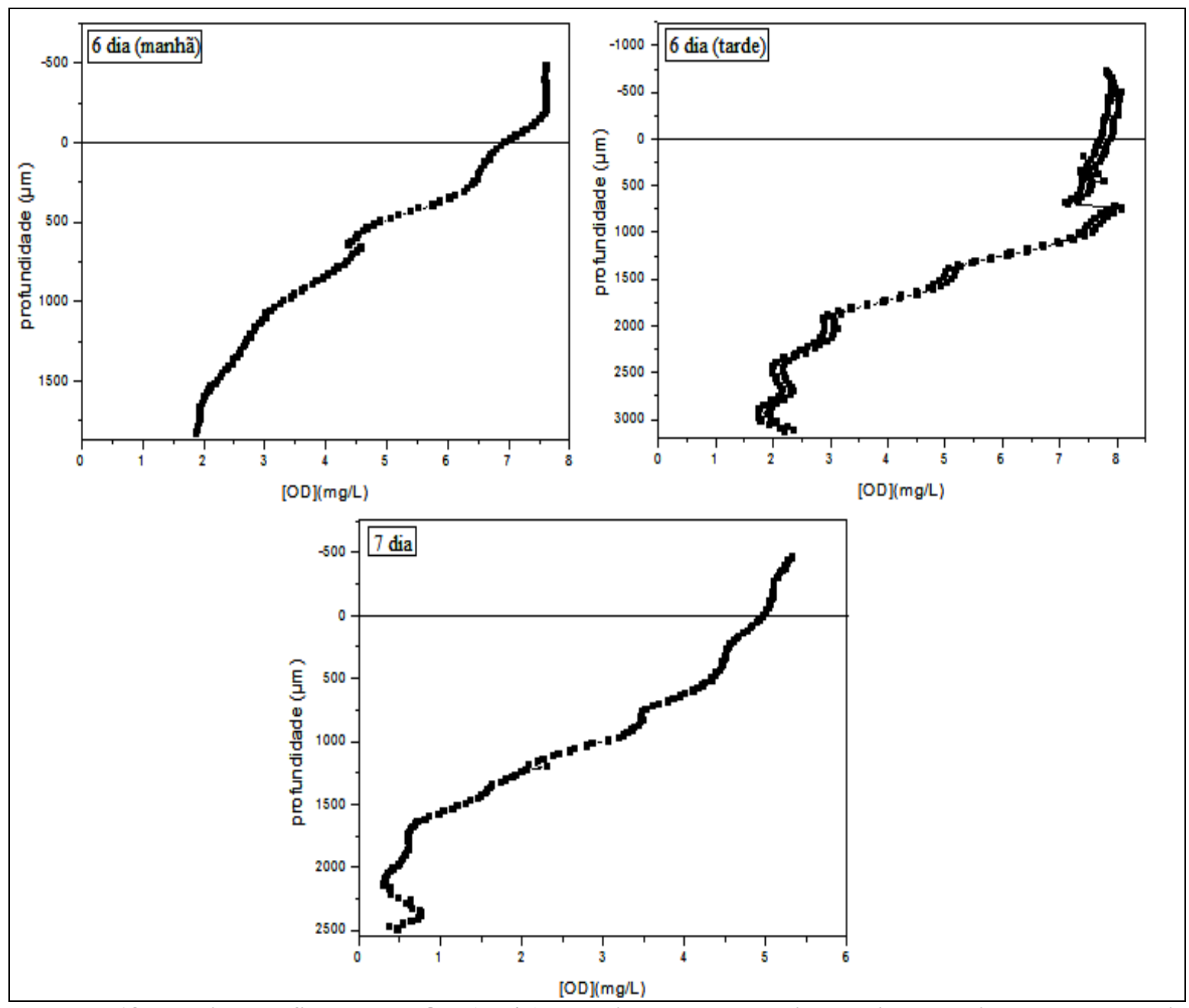

Figura 5. 18: Microperfis de $[\mathrm{OD}](\mathrm{mg} / \mathrm{L})$ obtidos nos dois últimos dias do experimento (Taxa carreg. $=1,5 \mathrm{~g} \mathrm{~N} / \mathrm{m}^{2}{ }_{\text {biofilme. }}$ dia, Vel. superficial $=1 \mathrm{~m} / \mathrm{h}, \mathrm{T}=25 \pm 2^{\circ} \mathrm{C}$ ). 
Micrografias (aumento de $200 \mathrm{X}$ ) do biofilme no último dia de operação da célula de fluxo foram obtidas a fim de se verificar se a formação de bolhas no interior do mesmo havia ocorrido, já que nesse dia baixos valores de concentração de OD foram determinados nas camadas mais internas do biofilme (Figura 5.19). Nessas micrografias foi possível constatar que o biofilme encontrava-se denso e que a produção de gás já havia sido iniciada.

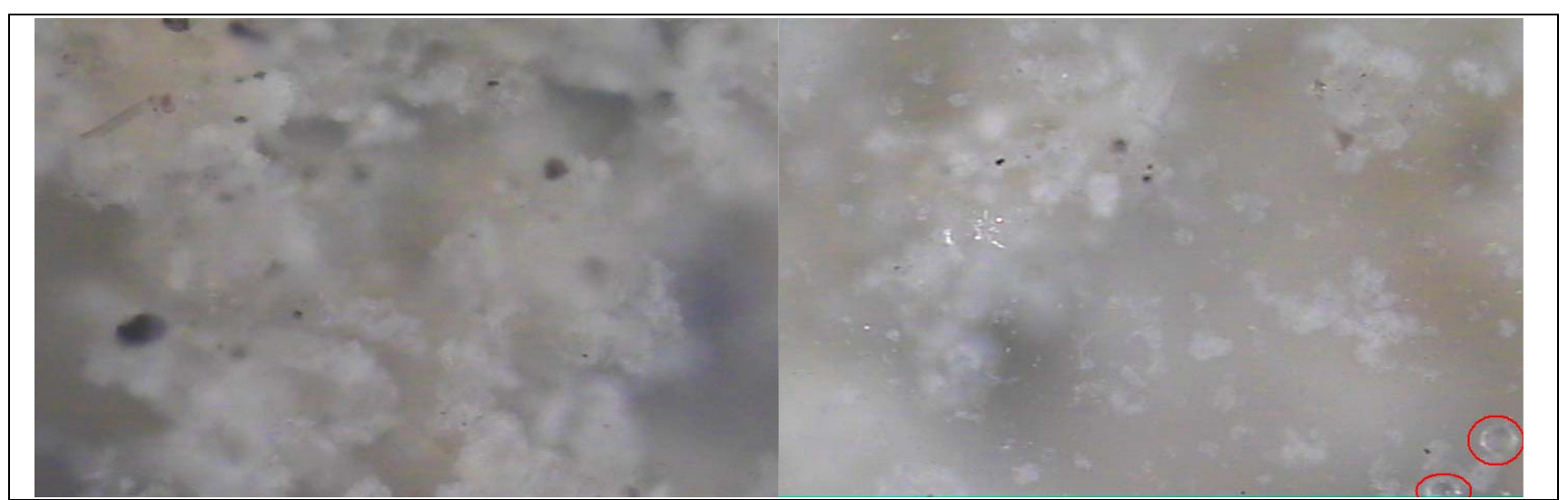

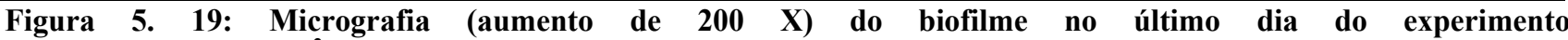
(Taxa carreg. $=1,5 \mathrm{~g} \mathrm{~N} / \mathrm{m}_{\text {biofilme.dia, Vel. superficial }}^{2}=1 \mathrm{~m} / \mathrm{h}$ ).

Análises físico-químicas das seguintes variáveis foram realizadas somente a partir do quarto dia após inicio da operação da célula de fluxo: $\mathrm{pH}$, alcalinidade, DQO, NTK, íons $\mathrm{NO}_{3}{ }^{-}$e $\mathrm{NO}_{2}{ }^{-}$do afluente e do efluente.

Como o objetivo do presente experimento era o de determinar em quanto tempo o biofilme desenvolvido na superfície do suporte demoraria a atingir a anaerobiose, as análises físico-químicas citadas anteriormente não foram feitas de forma periódica, conforme apresentado nas Tabelas 5.6, 5.7, 5.8 e 5.9 .

Tabela 5. 6: Valores de pH, alcalinidade e DQO no $4^{\circ}$ dia de operação da célula de fluxo.

\begin{tabular}{|c|c|c|c|}
\hline & $\mathbf{p H}$ & $\begin{array}{c}\text { Alcalinidade } \\
(\mathbf{m g C a C O} / \mathbf{L})\end{array}$ & DQO (mg/L) \\
\hline \hline Afluente & 7,4 & 252,2 & 110 \\
\hline Efluente & 8,1 & 221,4 & 33 \\
\hline
\end{tabular}

Tabela 5. 7: Valores de pH no afluente e efluente da célula de fluxo no $5^{\circ}$ dia de operação.

\begin{tabular}{|c|c|}
\hline & $\mathbf{p H}$ \\
\hline \hline Afluente & 7,6 \\
\hline Efluente & 8,0 \\
\hline
\end{tabular}


Tabela 5. 8: Resultados das análises físico-químicas realizadas no $6^{\circ}$ dia do experimento.

\begin{tabular}{|l|c|c|c|c|c|c|}
\hline & $\mathbf{p H}$ & $\begin{array}{c}\text { Alcalinidade } \\
\left.\mathbf{( m g C a C O}_{\mathbf{3}} / \mathbf{L}\right)\end{array}$ & $\mathbf{N T K}(\mathbf{m g} / \mathbf{L})$ & $\begin{array}{c}\mathbf{N O}_{\mathbf{3}}^{-} \\
\mathbf{( m g / L )}\end{array}$ & $\mathbf{N O}_{\mathbf{2}}^{-} \mathbf{( m g / L )}$ & $\begin{array}{c}\text { DQO } \\
\mathbf{( m g / L )}\end{array}$ \\
\hline \hline Afluente & 7,1 & 242,9 & 39,3 & 0,392 & 0,0104 & 70 \\
\hline Efluente & 8,2 & 232,1 & 26,3 & 0,294 & 0,0125 & 53 \\
\hline
\end{tabular}

Tabela 5. 9: Valores de pH e alcalinidade do último dia de operação da célula de fluxo.

\begin{tabular}{|c|c|c|}
\hline & $\mathbf{p H}$ & Alcalinidade $\left.\mathbf{( m g C a C O} \mathbf{m}_{\mathbf{3}} / \mathbf{L}\right)$ \\
\hline \hline Afluente & 7,7 & 241,4 \\
\hline Efluente & 8,3 & 213,1 \\
\hline
\end{tabular}

Os resultados dessas análises físico-químicas mostraram que no transcorrer da operação do sistema o pH do substrato sintético afluente foi mantido em 7,5 e o do efluente em 8,2. A alcalinidade do mesmo permaneceu em torno de $245,5 \mathrm{mg} / \mathrm{L}$ e a do efluente em $222,2 \mathrm{mg} / \mathrm{L}$. As análises das concentrações de NTK, de íons $\mathrm{NO}_{3}{ }^{-}$e $\mathrm{NO}_{2}{ }^{-}$sugeriram um consumo de $13 \mathrm{mg} \mathrm{NTK} / \mathrm{L}$ e uma pequena produção de 0,294 $\mathrm{mg} \mathrm{NO}_{2}{ }^{-} / \mathrm{L}$ e $0,0125 \mathrm{mg} \mathrm{NO}_{3}{ }^{-} / \mathrm{L}$. O valor da DQO de entrada mensurada foi igual a 80 e a de saída igual a $43 \mathrm{mg} / \mathrm{L}$.

Conclui-se com base em todos os resultados desse experimento que as condições de operação da célula de fluxo adotadas não foram apropriadas para o desenvolvimento de biofilmes nitrificantes. $\mathrm{O}$ consumo de OD ocorreu com velocidade elevada e em período de tempo curto (inferior a 48 horas) e através dos valores de remoção de DQO presumiu-se que este foi devido à ação de organismos heterótrofos que provavelmente se reproduziram de forma mais rápida que os organismos nitrificantes, que tiveram seu crescimento inibido pela presença dos primeiros.

\subsection{2- Experimento 2}

Os microperfis de OD obtidos nos biofilmes, desenvolvidos na superfície da célula de fluxo nos quatro dias iniciais desse experimento, encontram-se ilustrados na Figura 5.20. As micrografias do biofilme no primeiro e no terceiro dia estão apresentadas na Figura 5.21. 

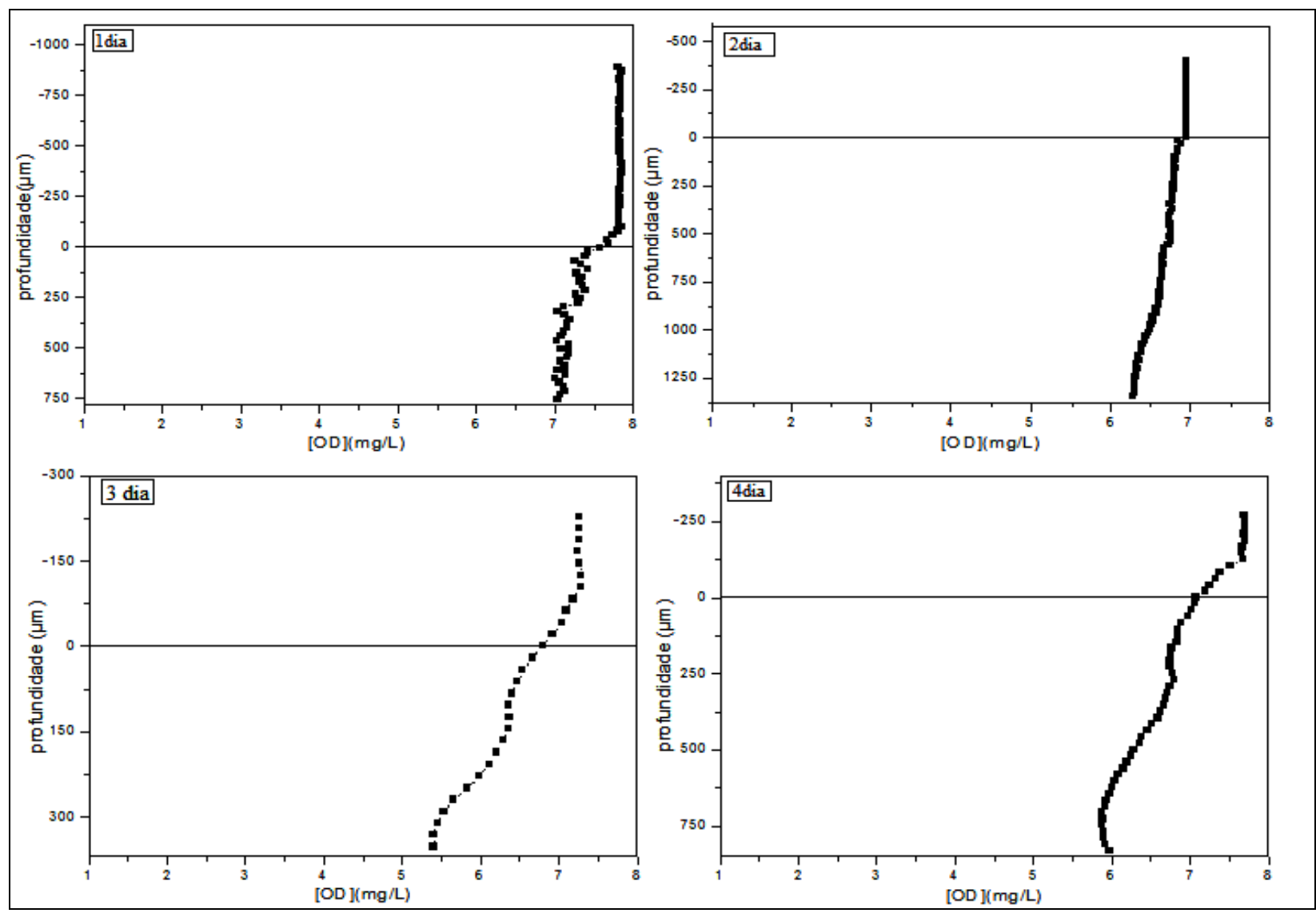

Figura 5. 20:Perfis de OD dos biofilmes dos quatro primeiros dias de operação da célula de fluxo (Taxa carreg. $=0,5 \mathrm{~g} \mathrm{~N} / \mathrm{m}_{\text {biofilme.dia, Vel. superficial }}^{2}=8 \mathrm{~m} / \mathrm{h}, \mathrm{T}=25 \pm 2^{\circ} \mathrm{C}$ ).

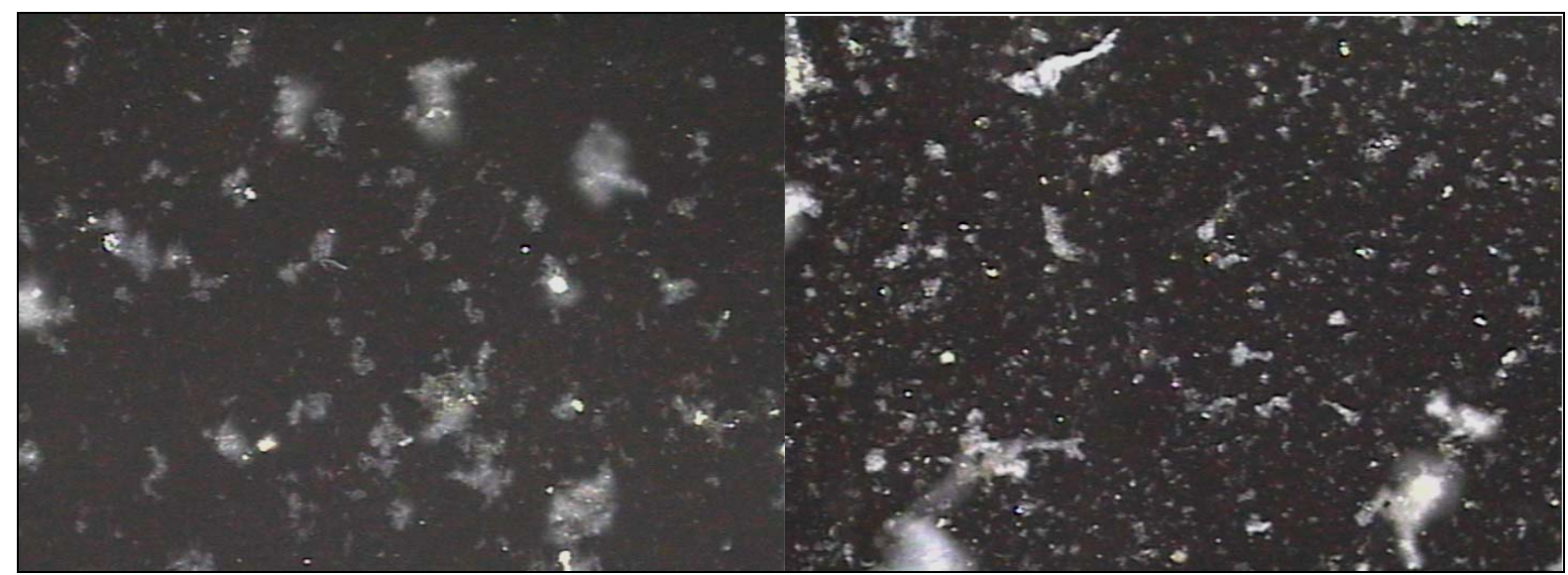

Figura 5. 21: Micrografias (aumento de $100 \mathrm{X}$ ) dos biofilmes no $1^{\circ}$ e $3^{\circ}$ dias do experimento, na devida ordem (Taxa carreg. $=0,5 \mathrm{~g} \mathrm{~N} / \mathrm{m}^{2}{ }_{\text {biofilmed }}$ dia, Vel. superficial $=8 \mathrm{~m} / \mathrm{h}$ ).

Por meio da análise dos perfis de OD determinados nos biofilmes nos quatro dias após o começo da operação da célula de fluxo verificou-se que a espessura média do biofilme aderido na superfície da célula de fluxo no decurso desses quatro dias foi de $940 \mu \mathrm{m}$ e a concentração de OD ao longo das espessuras dos mesmos permaneceu dentro do intervalo de $5,5 \mathrm{mg} / \mathrm{L}$ a $7,8 \mathrm{mg} / \mathrm{L}$. Tais fatos somados a 
observação das micrografias dos biofilmes, nas quais aglomerados pequenos e dispersos no meio líquido foram identificados, demonstraram que o crescimento do biofilme nesse experimento ocorreu de forma mais lenta que a do biofilme desenvolvido no ensaio anterior (Seção 5.3.1).

Nas Figuras 5.22 e 5.23 constam as micrografias dos biofilmes e os seus perfis de [OD].
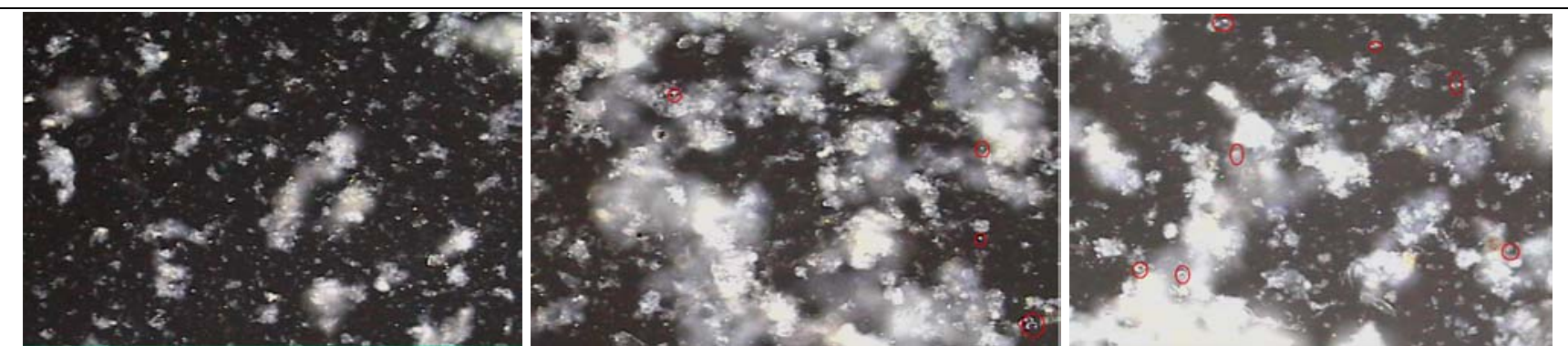

Figura 5. 22: Micrografias (aumento de $100 \mathrm{X}$ ) dos biofilmes no $5^{\circ}, 7^{\circ}$ e $9^{\circ}$ dias do experimento (Taxa carreg. $=0,5 \mathrm{~g} \mathrm{~N} / \mathrm{m}^{2}$ biofilme.dia, Vel. superficial $=8 \mathrm{~m} / \mathrm{h}$ ).

Mediante as micrografias foi notado que o biofilme encontrou-se em estágio de desenvolvimento mais avançado no sétimo e no nono dias. Bolhas de gases foram encontradas nos últimos dias de operação da célula de fluxo, enquanto que no quinto dia a formação de bolhas de gases não foi identificada.

Os perfis de OD, obtidos nos últimos cinco dias do experimento, confirmaram o evento relatado, concernente à velocidade com a qual o biofilme se desenvolveu no presente ensaio. Nesses, com exceção do perfil de OD do último dia, os valores das concentrações de OD mensuradas nas camadas mais internas dos biofilmes, que distavam de $1500 \mu \mathrm{m}$ das superfícies dos mesmos, ficaram em torno de $5,5 \mathrm{mg} / \mathrm{L}$. Apenas no último dia do experimento, baixas concentrações de OD $(\approx 1 \mathrm{mg} / \mathrm{L})$ foram detectadas nas zonas mais profundas do biofilme.

Tal fenômeno anteriormente descrito foi atribuído tanto a taxa de carregamento de $0,5 \mathrm{~g}$ $\mathrm{N} / \mathrm{m}^{2}$ biofilme.dia imposta ( 3 vezes menor do que a aplicada no ensaio precedente) quanto a velocidade superficial de $8 \mathrm{~m} / \mathrm{h}$ adotada ( 8 vezes maior do que a adotada no experimento 1 ) no experimento em questão, pois diante de uma menor disponibilidade de nutrientes e em presença de uma velocidade superficial elevada, o desenvolvimento de biofilmes ativos era para ser retardado conforme constatado.

A espessura máxima que o biofilme atingiu neste experimento foi de $2000 \mu \mathrm{m}$ ao passo que, no ensaio antecedente, biofilmes com até $4500 \mu \mathrm{m}$ de espessura foram formados. Justificam-se as diminuições das espessuras dos biofilmes: como a velocidade superficial empregada foi considerada como alta de acordo com o tamanho do reator de bancada utilizado, o estresse por cisalhamento foi significativamente aumentado e a taxa de remoção do biofilme foi consequentemente incrementada. 
Acredita-se que a remoção do excesso de biomassa também ocorreu por desprendimento devido à formação de bolhas de gases, segundo indica a Figura 5.22.

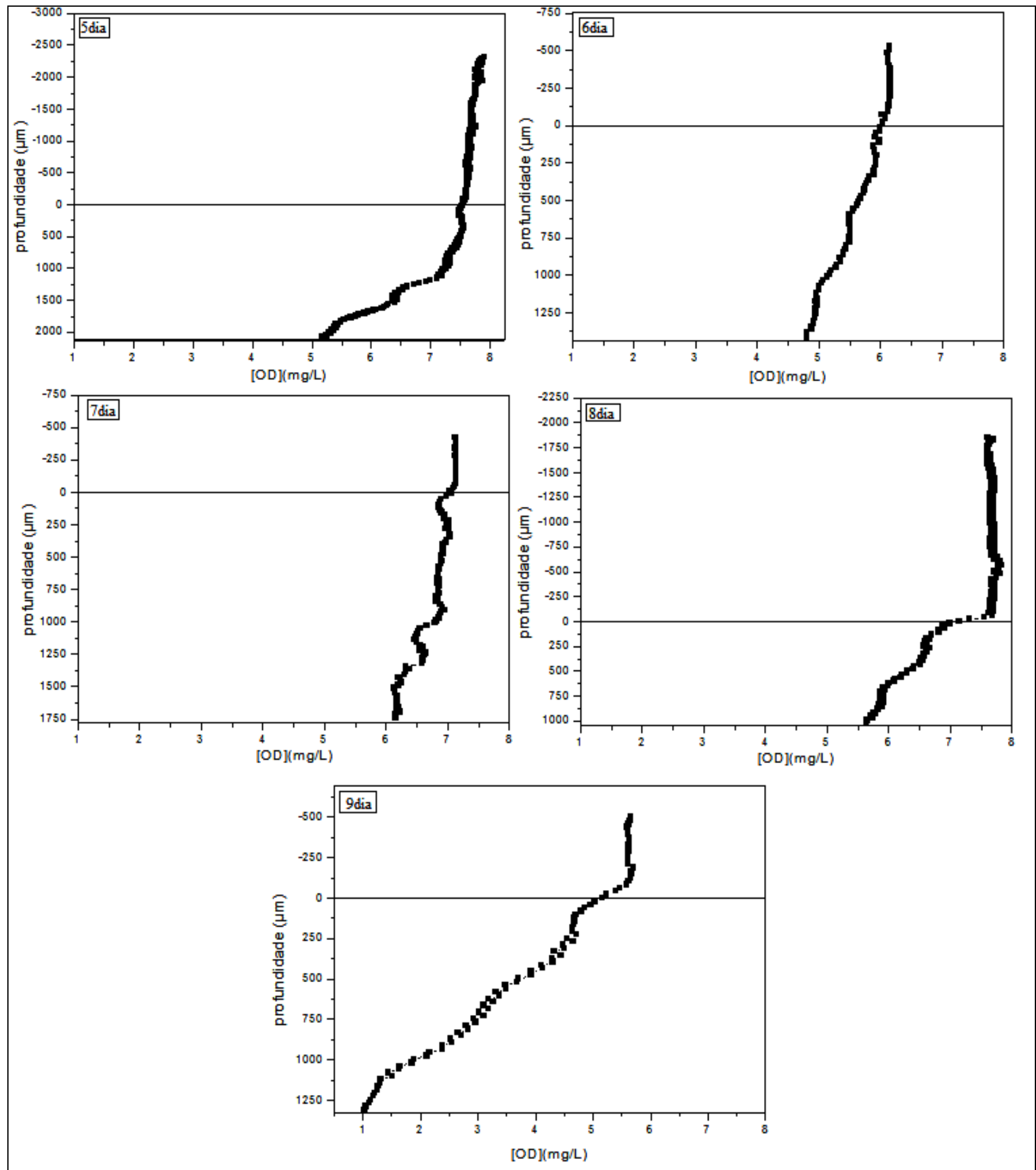

Figura 5. 23: Perfis de concentração de OD no interior dos biofilmes desenvolvidos nos dias restantes do experimento

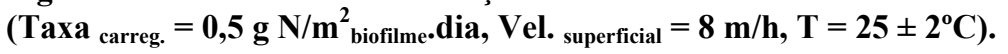


Tratando-se, dos resultados das análises físico-químicas de $\mathrm{pH}$, alcalinidade do afluente e efluente da célula de fluxo tem-se que os mesmos estão apresentados nas Figuras 5.24. e 5.25.

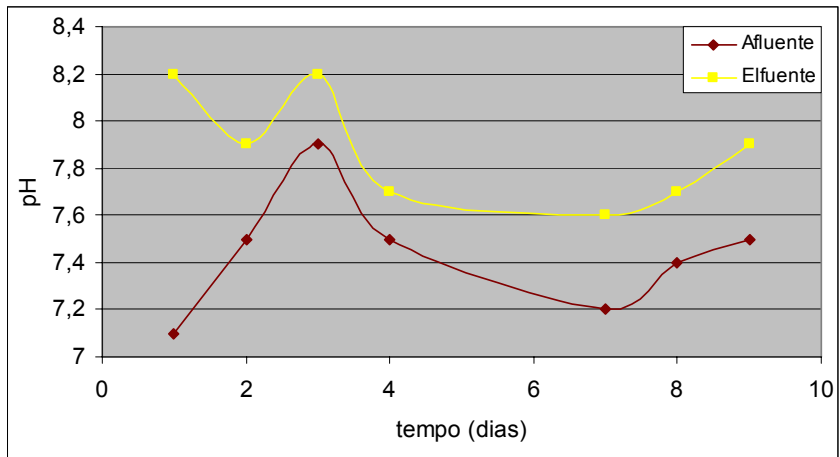

Figura 5. 24: Valores de $\mathrm{pH}$ do afluente e efluente da célula de fluxo ao longo do experimento

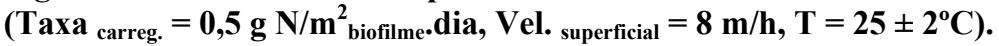

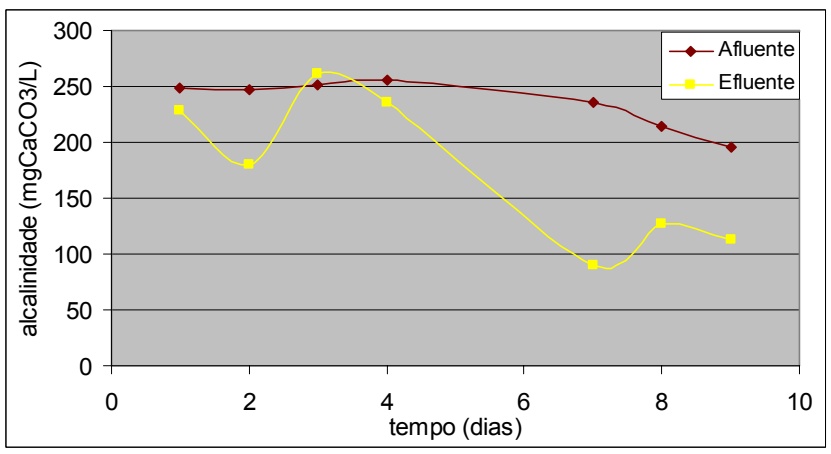

Figura 5. 25: Valores de alcalinidade no afluente e efluente da célula de fluxo (Taxa carreg. $=0,5 \mathrm{~g} \mathrm{~N} / \mathrm{m}^{2}{ }_{\text {biofilme.dia, }}$ Vel. superficial $=8 \mathrm{~m} / \mathrm{h}, \mathrm{T}=25 \pm 2^{\circ} \mathrm{C}$ ).

Através desses gráficos foi observado que durante a operação do sistema, os valores de $\mathrm{pH}$ no afluente e do efluente mantiveram-se em torno de 7,4 e de 7,8 , respectivamente. A alcalinidade nos mesmos ficou em torno de $236 \mathrm{mgCaCO}_{3} / \mathrm{L}$ e de $178 \mathrm{mgCaCO}_{3} / \mathrm{L}$, na mesma ordem. A demanda química de oxigênio do afluente variou de 20 a $40 \mathrm{mg} / \mathrm{L}$ e a do efluente variou de 40 a $90 \mathrm{mg} / \mathrm{L}$. As concentrações de nitrito e nitrato estão ilustradas na Figura 5.26.

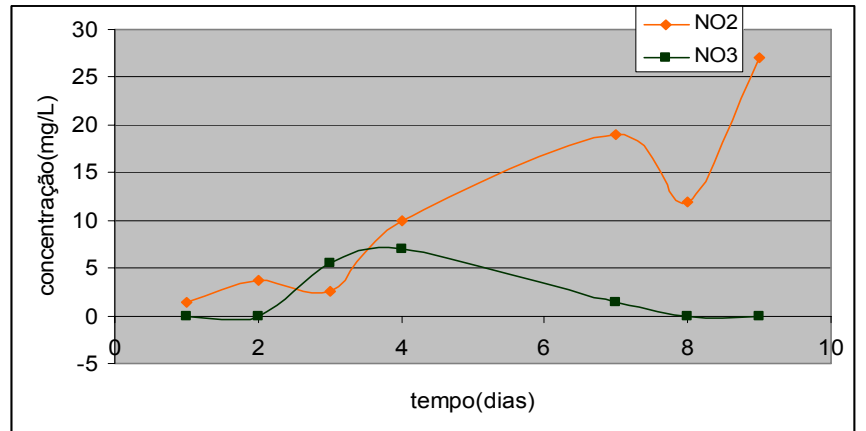

Figura 5. 26: Concentrações de íons nitrito $\left(\mathrm{NO}_{2}^{-}\right)$e nitrato $\left(\mathrm{NO}_{3}^{-}\right)$no efluente do sistema

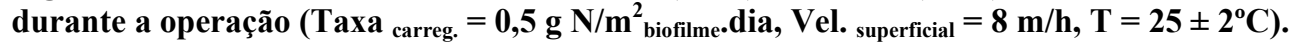


Por meio da interpretação dos gráficos de concentração dos íons nitrato e nitrito, pôde ser constatado que houve produção de até $27 \mathrm{mg} \mathrm{NO}_{2}{ }^{-} / \mathrm{L}$ e de $7 \mathrm{mg} \mathrm{NO}_{3}{ }^{-} / \mathrm{L}$. Aliando esses resultados aos referentes à alcalinidade e a DQO, inferiu-se que neste experimento a geração de bactérias nitrificantes não foi inibida pelo crescimento de organismos heterótrofos, pois não houve redução da DQO e ocorreu diminuição dos valores da alcalinidade, fator indicativo da ocorrência do processo de nitrificação.

A conclusão deste experimento foi a de que as condições operacionais adotadas para o sistema de célula de fluxo favoreceram o crescimento de biofilme nitrificante aeróbio. A aquisição dos perfis de OD foi feita até que tais concentrações se aproximassem de zero nas zonas mais profundas do biofilme, ao final de nove dias de operação.

Com base nos resultados deste experimento, foram realizados outros três experimentos, alterando-se apenas a quantidade de células de fluxo a serem operadas por teste, a taxa de carregamento de nitrogênio e as velocidades superficiais das mesmas. Esses ensaios foram denominados de experimento A, B e C.

\subsection{3 -Experimento A}

\subsubsection{1- Resultados das análises via microssensores}

Os resultados das análises feitas mediante o uso de microssensores de OD e de $\mathrm{pH}$ nos biofilmes das três células de fluxo no primeiro dia de operação das mesmas encontram-se expostos na Figura 5.27 .

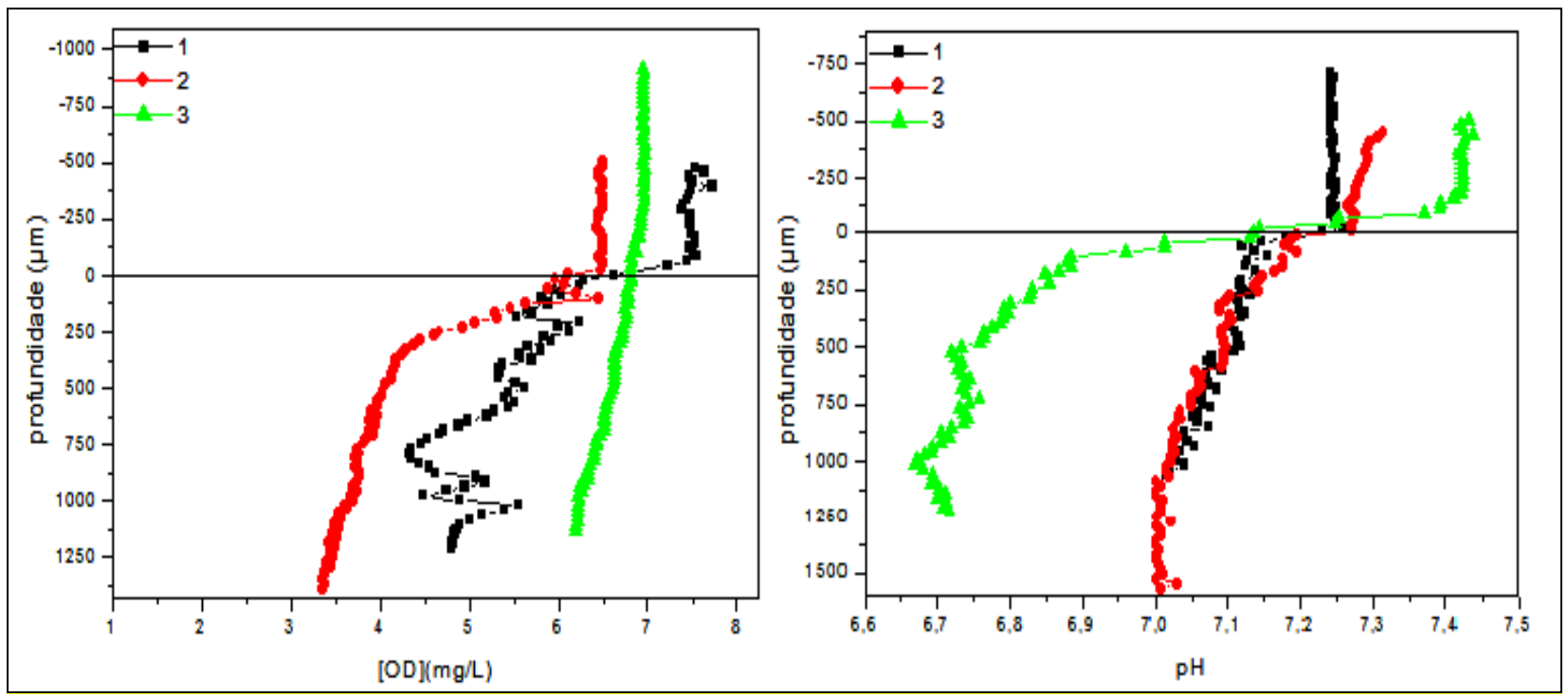

Figura 5. 27: Perfis de OD e de pH obtidos no $1^{\circ}$ dia de operação das células de fluxo 1; 2 e 3. Taxa $_{\text {carreg. }}=0,5 \mathrm{~g} \mathrm{~N} / \mathrm{m}^{2}{ }_{\text {biofilme.dia, Vel. superficial }}=1 \mathrm{~m} / \mathrm{h}$ (cél 1), $8 \mathrm{~m} / \mathrm{h}$ (cél 2) e $4 \mathrm{~m} / \mathrm{h}$ (cél 3), T= $25 \pm 2^{\circ} \mathrm{C}$. 
Ao analisar os perfis da Figura 5.27 observou-se que os biofilmes formados apresentaram em média $1500 \mu \mathrm{m}$ de espessura e que as concentrações de OD nas zonas mais profundas dos mesmos diferiram entre as células de fluxo 1, 2 e 3 no intervalo de 3,3 mg/L (célula de fluxo 2) à 6,2 $\mathrm{mg} / \mathrm{L}$ (célula de fluxo 3). Com relação aos perfis de pH, notou-se que nas células de fluxo 1 e 2 os mesmos exibiram comportamento semelhantes, nos quais se verificaram pequenos decréscimos do valor de $\mathrm{pH}$ no meio líquido para as camadas mais internas do biofilme, enquanto que no perfil da variável em questão da célula 3 maiores decréscimos dos valores de $\mathrm{pH}$ foram observados.

Nas Figuras 5.28 e 5.29 constam os microperfis de OD obtidos no $3^{\circ}$ e $6^{\circ}$ dia do experimento:

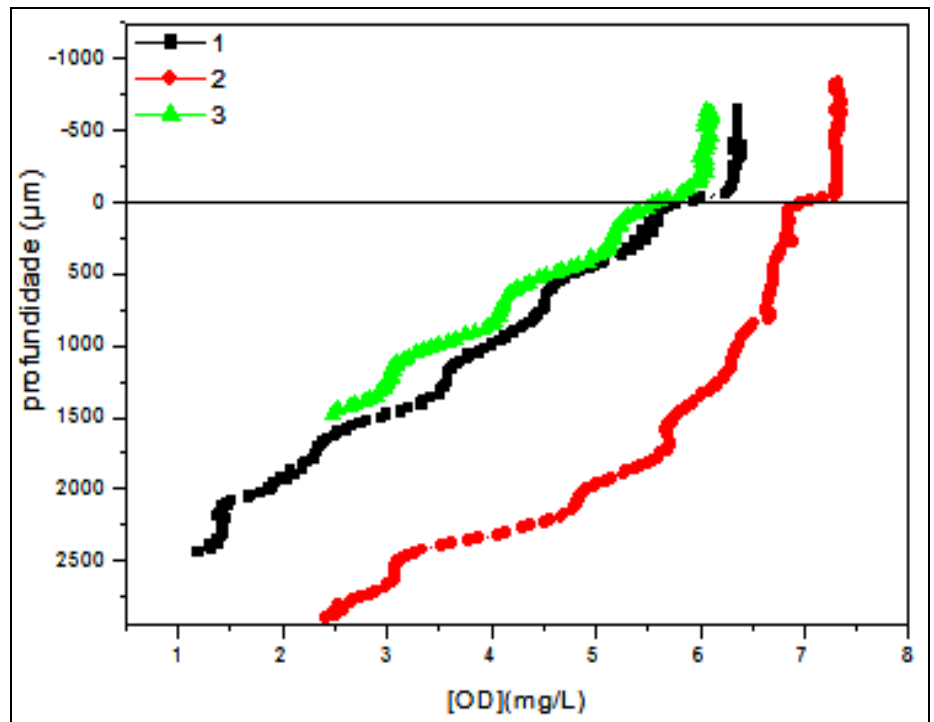

Figura 5. 28: Perfis de OD obtidos no $3^{\circ}$ dia de operação das células de fluxo $1 ; 2$ e 3. Taxa ${ }_{\text {carreg. }}=0,5 \mathrm{~g} \mathrm{~N} / \mathrm{m}_{\text {biofilme.dia, Vel. superficial }}^{2} 1 \mathrm{~m} / \mathrm{h}$ (cél 1), $8 \mathrm{~m} / \mathrm{h}$ (cél 2) e $4 \mathrm{~m} / \mathrm{h}$ (cél 3), $\mathrm{T}=25 \pm 2^{\circ} \mathrm{C}$.

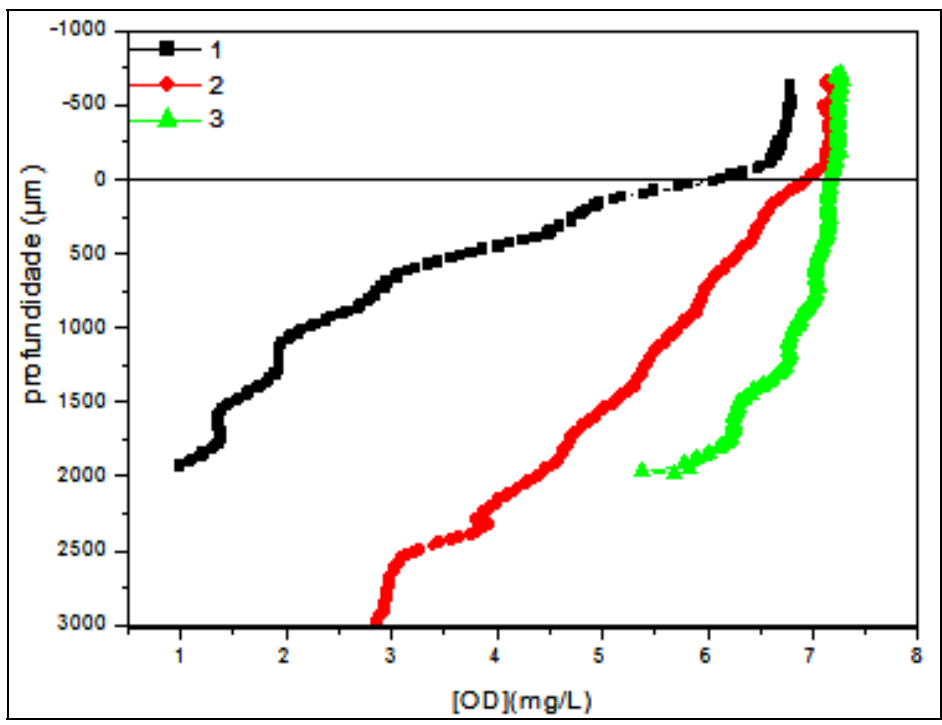

Figura 5. 29: Perfis de OD obtidos no $6^{\circ}$ dia de operação das células de fluxo $1 ; 2$ e 3. Taxa $_{\text {carreg. }}=0,5 \mathrm{~g} \mathrm{~N} / \mathrm{m}^{2}$ biofilme.dia, Vel. superficial $=1 \mathrm{~m} / \mathrm{h}$ (cél 1), $8 \mathrm{~m} / \mathrm{h}$ (cél 2) e $4 \mathrm{~m} / \mathrm{h}$ (cél 3), $\mathrm{T}=25 \pm 2^{\circ} \mathrm{C}$. 
Mediante os perfis de OD obtidos no experimento, pôde ser observado que o valores médio das concentrações de OD detectadas nas camadas mais internas dos biofilmes nas três células no $3^{\circ}$ dia de operação das mesmas foi de $2,7 \mathrm{mg} / \mathrm{L}$. No sexto dia depois do início do experimento os valores de OD determinados nas zonas mais profundas dos biofilmes aderidos nas três células de fluxo foram distintos, pois nas células de fluxo 1; 2 e 3 concentrações de $1 \mathrm{mg} / \mathrm{L}, 3 \mathrm{mg} / \mathrm{L}$ e de $6 \mathrm{mg} / \mathrm{L}$ foram medidas.

Estimou-se que, em tal dia, as altas concentrações de OD identificadas no biofilme desenvolvido na célula de fluxo 3 foram consequentes do término precoce (em período de tempo inferior ao de seis dias) do ciclo de crescimento, fixação e liberação de material celular por perda de agregados maiores do biofilme, os quais foram arrastados da célula de fluxo. Se isso de fato ocorreu, mensuraram-se as concentrações de OD apenas do meio líquido (livre de biomassa imobilizada) da célula de fluxo.

Outro acontecimento que pode ter ocasionado a detecção de altas concentrações de OD no biofilme da célula de fluxo 3 consiste na introdução do microssensor de OD em um "canal" do biofilme no qual a penetração do líquido ocorre. Assim sendo, o perfil de OD obtido seria referente ao meio líquido circundante ao biofilme.

Os perfis das concentrações de íons nitrato no interior dos biofilmes, obtidos no oitavo dia após o início da operação das células de fluxo podem ser observados na Figura 5.30:

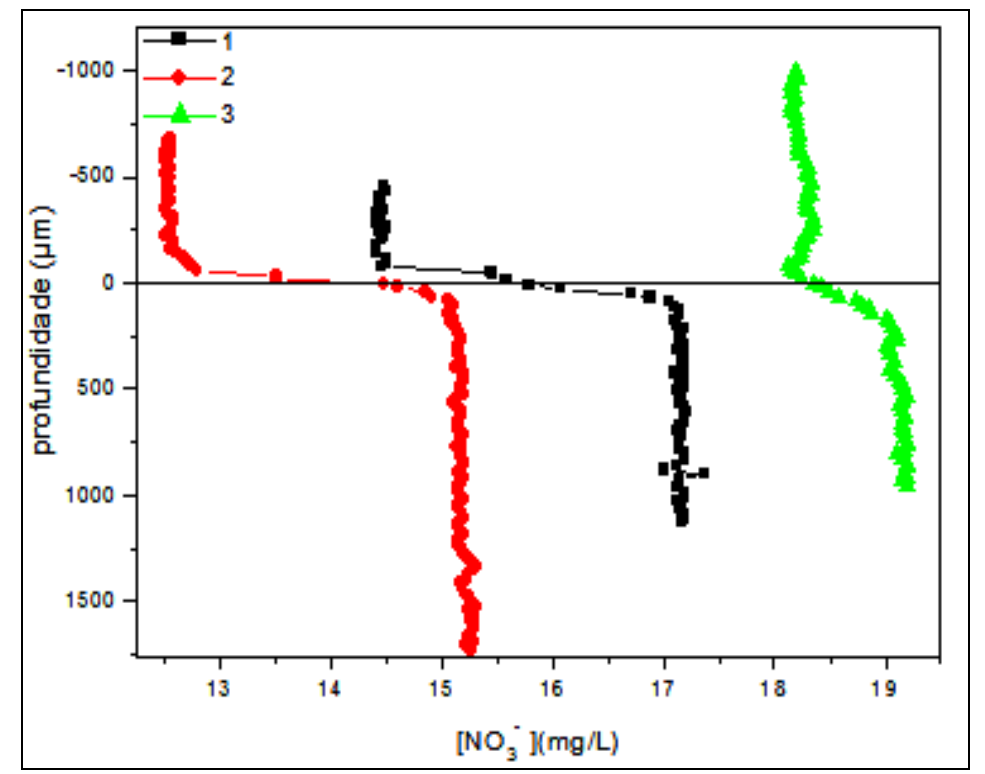

Figura 5. 30: Perfis de $\mathrm{NO}_{3}^{-}$obtidos no $8^{\circ}$ dia de operação das células de fluxo $1 ; 2$ e 3. Taxa carreg. $=0,5 \mathrm{~g} \mathrm{~N} / \mathrm{m}^{2}{ }_{\text {biofilme.dia, Vel. superficial }}=1 \mathrm{~m} / \mathrm{h}$ (cél 1), $8 \mathrm{~m} / \mathrm{h}$ (cél 2) e $4 \mathrm{~m} / \mathrm{h}$ (cél 3), T $=25 \pm 2^{\circ} \mathrm{C}$.

Os microperfis dos íons $\mathrm{NO}_{3}^{-}$nos biofilmes desenvolvidos nas três células de fluxo indicaram aumentos das concentrações dos íons em questão no sentido do meio líquido para o interior do biofilme onde se presume que a oxidação do íon amônio a íons nitrito e posteriormente a íons nitrato ocorria pela 
ação das bactérias nitratantes e nitritantes, respectivamente. Tais aumentos apresentaram maiores magnitudes nas células de fluxo 1 e 2 .

\subsubsection{2- Resultados das análises físico-químicas}

Abordando-se, agora, dos resultados das análises físico-químicas, análises de DQO, NTK, alcalinidade e $\mathrm{pH}$ do afluente foram efetuadas, a fim de se verificar a estabilidade dos valores de concentrações de seus componentes ao longo da operação das células de fluxo. As concentrações de NTK variaram dentro da faixa de 30 a $35 \mathrm{mg} / \mathrm{L}$ enquanto que os valores de DQO foram mantidos em torno de 90 a $120 \mathrm{mg} / \mathrm{L}$ no decorrer do experimento. As demais características do afluente apresentamse nas Figuras 5.31, 5.32 e 5.33, juntamente com os resultados das análises físico-químicas alcançados no presente experimento relacionadas aos efluentes das três células de fluxo.

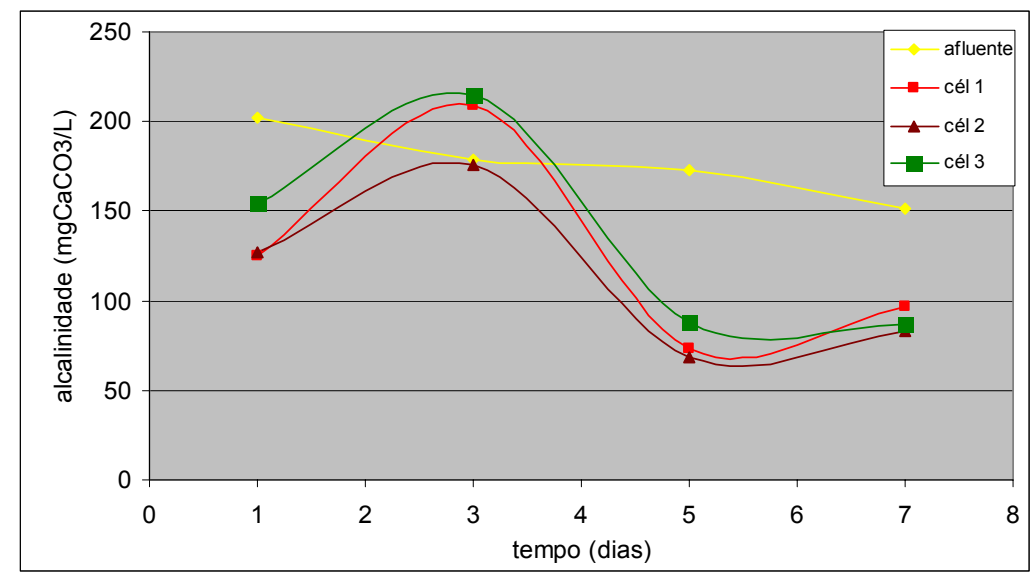

Figura 5. 31: Alcalinidade do afluente e dos efluentes das três células de fluxo (1; 2 e 3). Taxa $_{\text {carreg. }}=0,5 \mathrm{gN} / \mathrm{m}^{2}{ }_{\text {biofilme.dia, Vel. superficial }}=1 \mathrm{~m} / \mathrm{h}$ (cél 1), $8 \mathrm{~m} / \mathrm{h}$ (cél 2) e $4 \mathrm{~m} / \mathrm{h}$ (cél 3), $\mathrm{T}=25 \pm 2^{\circ} \mathrm{C}$.

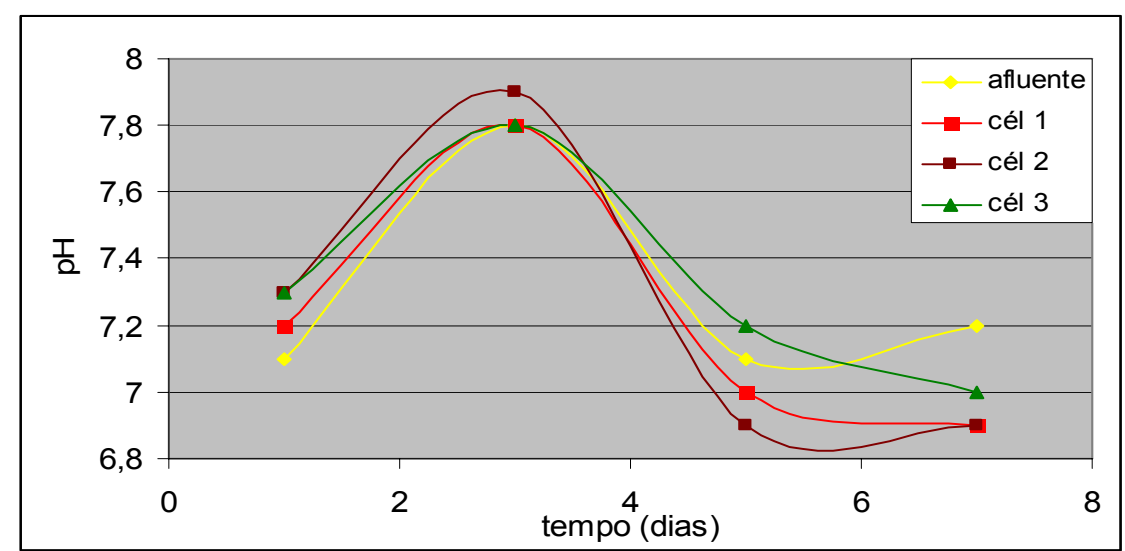

Figura 5. 32: Valores de pH no afluente e nos efluentes das três células de fluxo. Taxa $_{\text {carreg. }}=0,5{\mathrm{~g} \mathrm{~N} / \mathrm{m}^{2}{ }_{\text {biofilme.dia, Vel. }} \text { superficial }}=1 \mathrm{~m} / \mathrm{h}$ (cél 1), $8 \mathrm{~m} / \mathrm{h}$ (cél 2) e $4 \mathrm{~m} / \mathrm{h}$ (cél 3), $\mathrm{T}=25 \pm 2^{\circ} \mathrm{C}$. 
A partir da análise dos gráficos apresentados nas Figuras 5.31 e 5.32 concluiu-se: a redução nos valores da alcalinidade nas três células ao longo da operação sinalizou a ocorrência de nitrificação, pois na mesma ocorre consumo da alcalinidade. Como consequência da redução da alcalinidade, ocorreram pequenas diminuições dos valores de $\mathrm{pH}$ nas três células, as quais foram análogas ao abaixamento da alcalinidade. Os gráficos de concentrações e consumo de NTK estão apresentados na Figura 5.33.
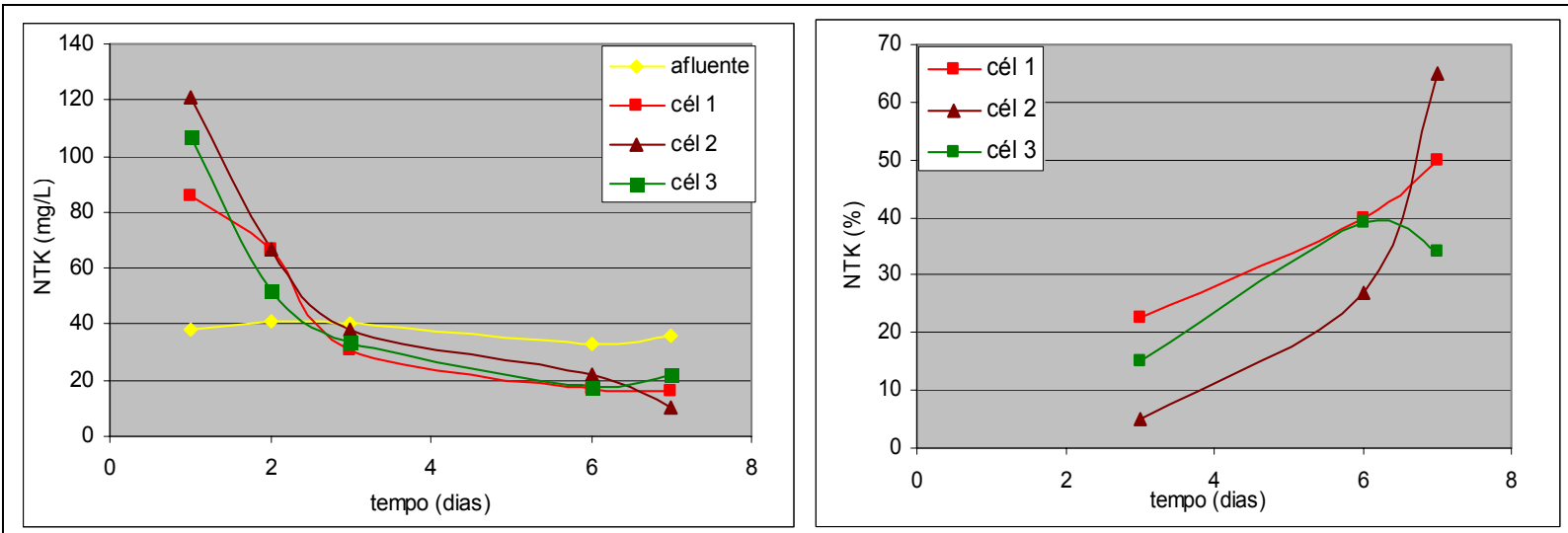

Figura 5. 33: Concentrações de NTK no afluente e nos efluentes das três células de fluxo (esquerda). Consumo de NTK (\%) nas três células de fluxo (direita). Taxa carreg. $=0,5 \mathrm{~g} \mathrm{~N} / \mathrm{m}^{2}{ }_{\text {biofilme.dia, Vel. superficial }}=1 \mathrm{~m} / \mathrm{h}$ (cél 1), $8 \mathrm{~m} / \mathrm{h}$ (cél 2) e $4 \mathrm{~m} / \mathrm{h}$ (cél 3), $\mathrm{T}=25 \pm 2^{\circ} \mathrm{C}$.

A partir dos gráficos expostos na Figura 5.33 se constatou o seguinte: nos dois primeiros dias de operação das três células de fluxo ocorreu o acúmulo de NTK ao invés de seu consumo. O consumo de NTK ocorreu nas três células apenas a partir do terceiro dia de operação das mesmas.

Primeiramente, presumiu-se que a "geração" de NTK que se deu nos dois dias iniciais do experimento, foi provavelmente devida a ocorrência de processo de amonificação do nitrogênio orgânico presente nos grânulos do lodo de inóculo, que se encontrava indevidamente na superfície da célula de fluxo. No momento precedente ao início da alimentação das células de fluxo com o substrato sintético, a remoção do lodo de inóculo não foi realizada de maneira adequada fazendo com que sobrassem resquícios do mesmo na superfície das células de fluxo. A produção da alcalinidade que se deu nos dois primeiros dias do experimento confirma a hipótese alusiva a ocorrência de amonificação, já que essa acontece com o aumento da concentração de alcalinidade (OLIVEIRA, 2003).

O maior consumo de NTK nas três células de fluxo, ocorrido nos dois últimos dias de operação das mesmas foi coerente com os maiores consumos de alcalinidade observados também no fim do experimento.

A Figura 5.34 contém os gráficos das concentrações dos íons nitrato e nitrito nos efluentes das três células de fluxo. 


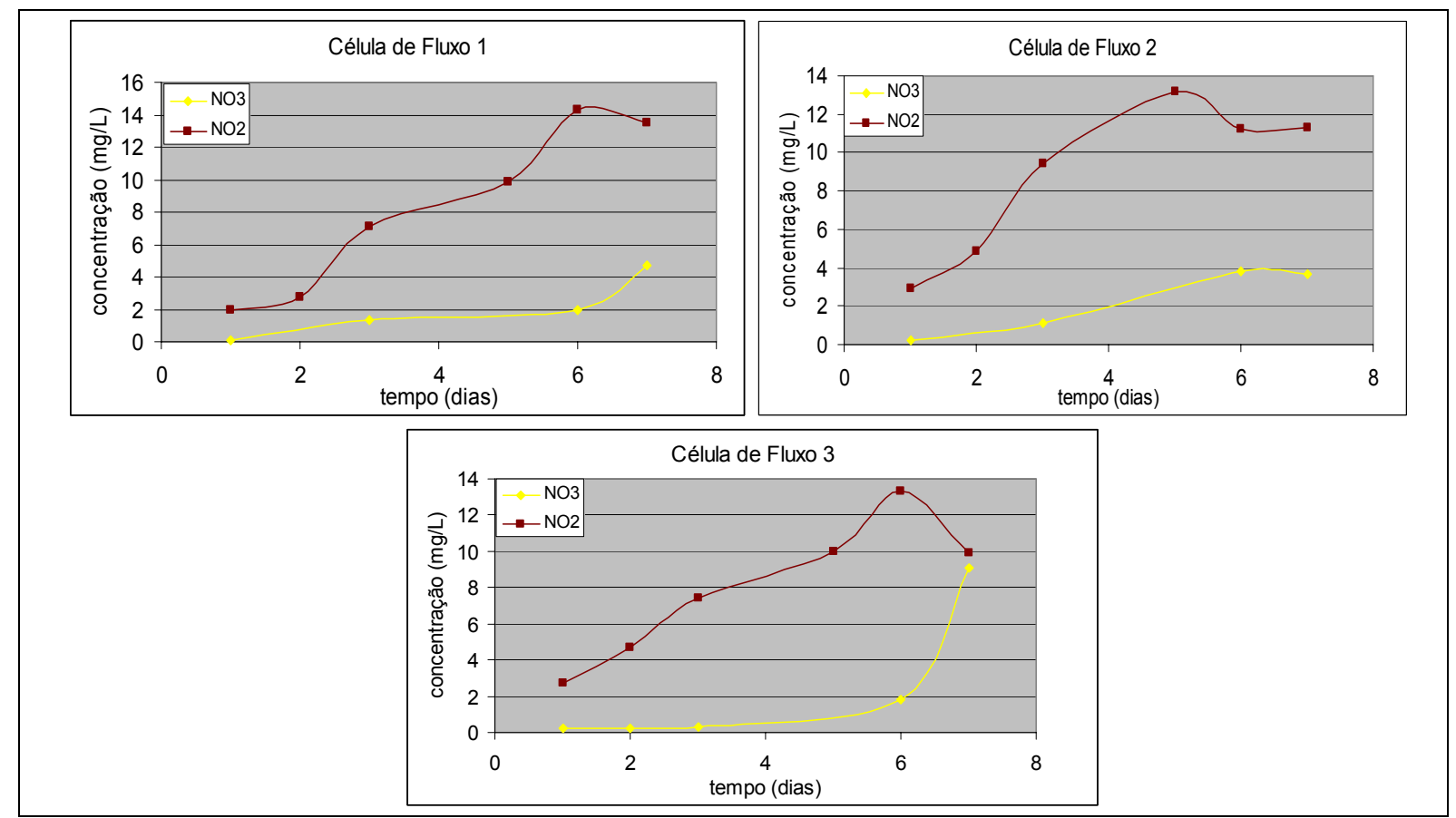

Figura 5. 34: Concentrações dos íons $\mathrm{NO}_{2}^{-}$e $\mathrm{NO}_{3}^{-}$nos efluentes das três células de fluxo $(1 ; 2$ e 3). Taxa carreg. $=0,5 \mathrm{~g} \mathrm{~N} / \mathrm{m}_{\text {biofilme.dia, Vel. superficial }}^{2} 1 \mathrm{~m} / \mathrm{h}$ (cél 1), $8 \mathrm{~m} / \mathrm{h}$ (cél 2) e $4 \mathrm{~m} / \mathrm{h}$ (cél 3), $\mathrm{T}=25 \pm 2^{\circ} \mathrm{C}$.

Observou-se nas figuras que as concentrações dos íons nitrito apresentaram-se maiores que as dos íons nitrato nos efluentes das três células de fluxo. Foi notado também que as maiores concentrações de ambos os íons nas três células de fluxo foram detectadas nos últimos dias do experimento, analogamente aos maiores consumos de NTK e de alcalinidade.

Conjecturou-se, portanto, a ocorrência da nitrificação via nitrito, na qual o acúmulo de íons nitrito acontece devido a uma série de fatores, os quais se relacionam com a concentração de OD do meio, valores de $\mathrm{pH}$, relação de $\mathrm{DQO} / \mathrm{N}$, temperatura, entre outros. Para análise da possibilidade da ocorrência de tal processo alguns dados da literatura concernentes a esse assunto foram levantados e detalhados adiante.

Bae et al. (2002) relataram que o acúmulo de nitrito foi favorecido em reator alimentado com substrato sintético contendo $50 \mathrm{mg} / \mathrm{L}$ de nitrogênio amoniacal, concentrações de OD de 2 a $3 \mathrm{mg} / \mathrm{L}$, temperatura de $30{ }^{\circ} \mathrm{C}$ e pH na faixa de 8 e 9. Yoo et al. (1999) recomendam concentrações de OD próxima de $1,3 \mathrm{mg} / \mathrm{L}$, elevados valores de $\mathrm{pH}$ do meio, temperaturas próximas a $25^{\circ} \mathrm{C}$ para acumulação de nitrito. Polanco, Villaverde e Garcia (1997) relatam que a acumulação de íons nitrito no meio é iniciada a partir de pH 7,5. Abeling e Seyfried (1992) obtiveram eficiência de $90 \%$ na remoção de nitrogênio via nitrito com relação de DQO/N igual a 2,8. 
Ao considerar os seguintes fatos: o substrato sintético utilizado apresentava concentrações de nitrogênio amoniacal de $40 \pm 10 \mathrm{mg} / \mathrm{L}$ e relação DQO/N igual a 3; as concentrações de OD nas partes mais internas do biofilme situaram-se dentro da faixa de 1 a $3 \mathrm{mg} / \mathrm{L}$ no $3^{\circ}$ e no $6^{\circ}$ dia do experimento; os valores de $\mathrm{pH}$ mensurados ao longo do experimento ficaram dentro do intervalo de 6,8 a 8 ; a temperatura sob a qual as células de fluxo foram operadas foi mantida em $25^{\circ} \mathrm{C}$; assumiu-se que a remoção de nitrogênio via nitrito pode ter ocorrido nas três células de fluxo operadas no presente experimento.

\subsubsection{3- Resultados - Microssensores e análises físico-químicas}

Aliando-se os resultados das análises físico-químicas, com os perfis de concentrações das espécies químicas obtidos mediante uso de microssensores foram inferidas as constatações descritas posteriormente.

Cabe salientar antes da apresentação de tais constatações que, os resultados das variáveis de pH e íons nitrato obtidos no meio líquido que escoa junto ao biofilme aderido nas superfícies das células de fluxo através do uso de microssensores foram comparados com os revelados por meio das análises físico-químicas, pois o local da célula de fluxo no qual as amostras foram coletadas para efetivação das últimas coincidiu (propositalmente) com o local em que os microssensores eram introduzidos no interior dos biofilmes para aquisição dos microperfis.

Assim, houve coerência entre os valores de $\mathrm{pH}$ no meio líquido das três células de fluxo obtidos mediante aplicação dos microssensores e realização das análises físico-químicas, no primeiro dia do experimento (único dia em que perfis de $\mathrm{pH}$ foram obtidos via microssensores), fato esse que indicou bom desempenho dos microeletrodos em questão. A diminuição dos valores de $\mathrm{pH}$ do meio líquido para o interior dos biofilmes foi constatada através do uso dos mesmos. Foi suposto que tal diminuição de pH tenha sido consequência do início da oxidação do $\mathrm{N}_{-} \mathrm{NH}_{4}{ }^{+}$no interior dos biofilmes.

Relacionando-se os microperfis de íons $\mathrm{NO}_{3}{ }^{-}$com os resultados das análises físico-químicas referentes a esses íons foi constatado que os dados estavam incoerentes, pois a partir das mesmas foram mensurados valores de concentrações de íons nitrato muito inferiores aos obtidos no meio líquido das células de fluxo via microssensores. Ademais, verificou-se que as concentrações dos íons nitrato determinadas com os microssensores no meio aquoso se assemelhavam mais as concentrações de íons nitrito detectadas nas análises físico-químicas.

O resultado obtido no teste de seletividade dos microssensores de íons nitrato (Seções 4.3.2 e 5.2.2.) corroborou com o observado no experimento em questão, isto é, os microssensores construídos 
para detecção de nitrato, apresentaram resposta linear aos íons nitrito. Dessa forma, confirmou-se que os microssensores de íons nitrato estavam detectando na realidade, os dois íons: nitrato e nitrito $\left(\mathrm{NO}_{\mathrm{x}}^{-}\right)$.

\subsubsection{4- Conclusões do experimento}

Concluiu-se, neste experimento que os microssensores destinados à análise de concentrações de oxigênio dissolvido e de íons $\mathrm{H}^{+}$se mostraram eficientes, todavia os designados para determinação de íons nitrato não apresentaram seletividade, pois íons nitrito foram também detectados pelos mesmos.

Foi concluído também, através dos perfis de íons nitrato (ou de $\mathrm{NO}_{\mathrm{x}}{ }^{-}$) e das análises físicoquímicas, que a oxidação do nitrogênio amoniacal a íons nitrito ocorreu no interior dos biofilmes desenvolvidos nas três células de fluxo, ao passo que a oxidação dos íons nitrito a nitrato foi menos expressiva, sendo esta última a razão pela qual se considerou a possibilidade da ocorrência da nitrificação via nitrito.

\subsection{4-Experimento $B$}

\subsubsection{1- Resultados das análises via microssensores}

Os microperfis das espécies químicas detectadas pelo uso de microssensores, ao longo da operação das três células de fluxo, encontram-se nas Figuras 5.35; 5.36; 5.37; 5.38 e 5.39:

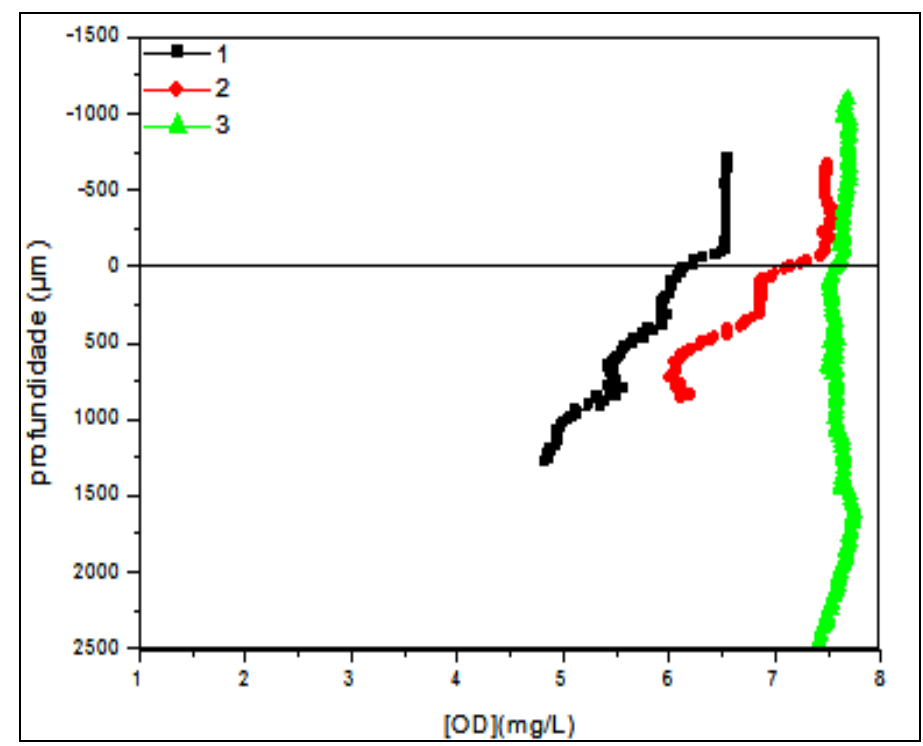

Figura 5. 35: Microperfis de oxigênio dissolvido nos biofilmes das três células de fluxo $1^{\circ}$ dia de operação Taxa carreg. $=1,0 \mathrm{~g} \mathrm{~N} / \mathrm{m}^{2}{ }_{\text {biofilme.dia, Vel. superficial }}=1 \mathrm{~m} / \mathrm{h}$ (cél 1), $8 \mathrm{~m} / \mathrm{h}$ (cél 2) e $4 \mathrm{~m} / \mathrm{h}$ (cél 3), $\mathrm{T}=25 \pm 2^{\circ} \mathrm{C}$.

Observou-se nesses perfis de OD que houve diminuição das concentrações de OD nas zonas mais internas dos biofilmes desenvolvidos nas células de fluxo 1 e 2, ao passo que na célula de fluxo 3 
o oxigênio dissolvido difundiu- se ao longo da totalidade da espessura do biofilme aderido na mesma $(2500 \mu \mathrm{m})$. De acordo com as limitações de difusão do oxigênio dissolvido em biofilmes espessos, foi suposto que o perfil de OD obtido na célula de fluxo 3 foi equivalente às concentrações de OD presentes no meio líquido localizado em uma reentrância ou cavidade do biofilme aderido na superfície suporte da célula em questão. Assim, estimou-se que tal biofilme possuía espessura inferior a $2500 \mu \mathrm{m}$.

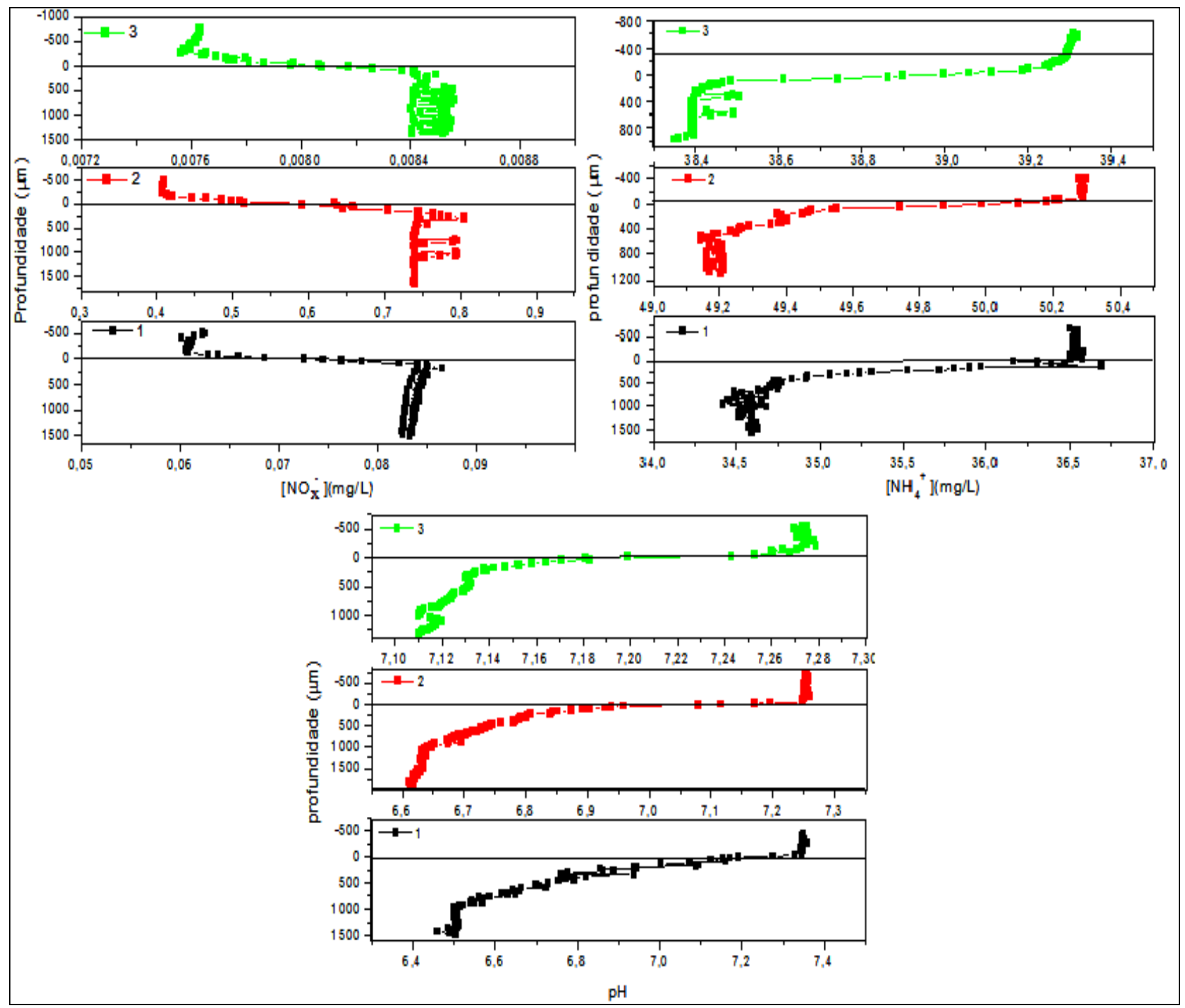

Figura 5. 36: Microperfis de íons $\mathrm{NO}_{\mathrm{x}}^{-}$, de íons amônio $\left(\mathrm{NH}_{4}{ }^{+}\right)$e de $\mathrm{pH}$ nos biofilmes das três células de fluxo no $2^{\circ}$ dia do experimento. Taxa carreg. $=1,0 \mathrm{~g} \mathrm{~N} / \mathrm{m}^{2}{ }_{\text {biofilme.dia, Vel. superficial }}=1 \mathrm{~m} / \mathrm{h}$ (cél 1), $8 \mathrm{~m} / \mathrm{h}$ (cél 2 ) e $4 \mathrm{~m} / \mathrm{h}$ (cél 3 ), $\mathrm{T}=\mathbf{2 5} \pm \mathbf{2}^{\circ} \mathrm{C}$.

Por meio dos perfis revelados na Figura 5.36 se verificou a ocorrência de pequeno aumento das concentrações de íons $\mathrm{NO}_{\mathrm{x}}{ }^{-}$nas três células de fluxo no sentido do meio líquido para o interior do biofilme, enquanto que o inverso foi constatado para os íons $\mathrm{NH}_{4}{ }^{+}$e para o $\mathrm{pH}$ nas referidas células. 


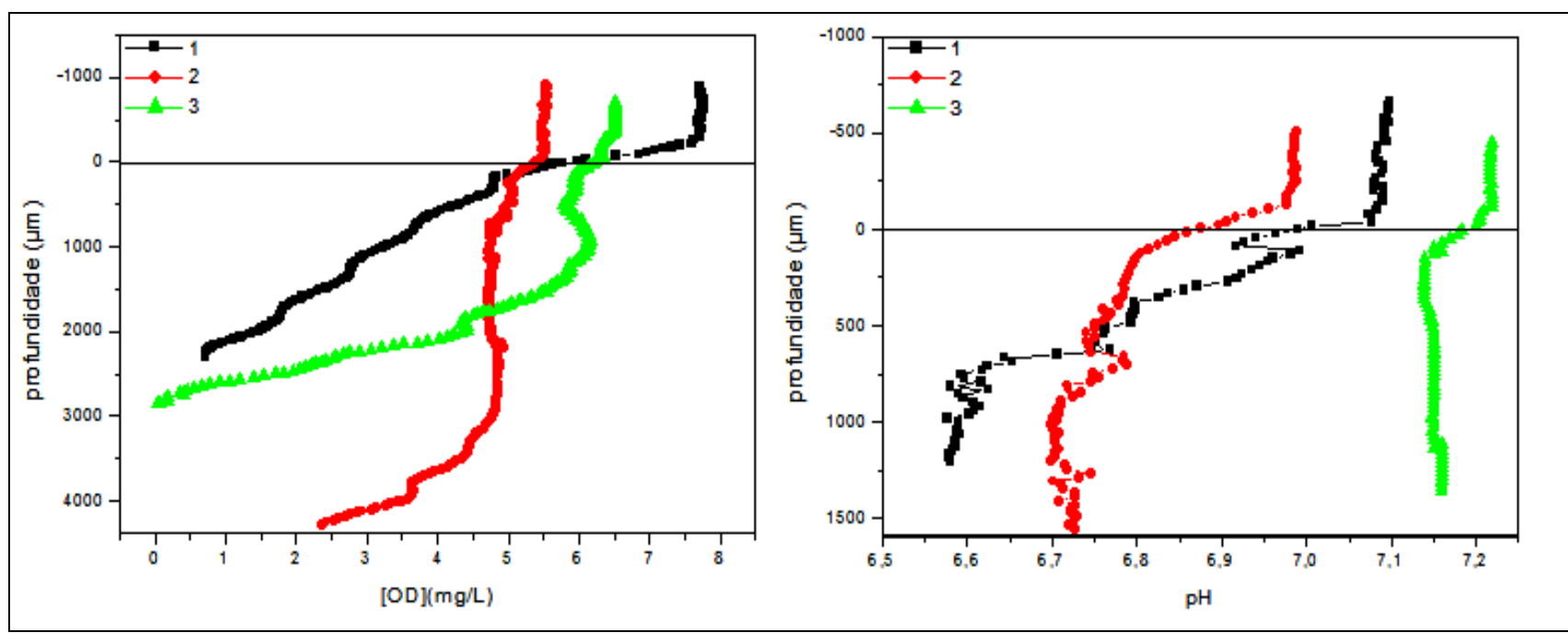

Figura 5. 37: Microperfis de OD e de pH nos biofilmes das três células de fluxo no $5^{\circ}$ dia do experimento. Taxa $_{\text {carreg. }}=1,0 \mathrm{~g} \mathrm{~N} / \mathrm{m}^{2}$ biofilme.dia, Vel. superficial $=1 \mathrm{~m} / \mathrm{h}\left(\right.$ cél 1), $8 \mathrm{~m} / \mathrm{h}$ (cél 2) e $4 \mathrm{~m} / \mathrm{h}\left(\right.$ cél 3), $\mathrm{T}=25 \pm 2^{\circ} \mathrm{C}$.

Visto que os perfis de OD e pH presentes na Figura 5.37 foram realizados apenas no $5^{\circ}$ dia do experimento, significantes mudanças concernentes à espessura dos biofilmes das três células de fluxo e aos valores das concentrações de OD e de $\mathrm{pH}$ no interior das mesmas foram identificadas.

Nas zonas profundas dos biofilmes nas células de fluxo 1 e 3 que distavam de aproximadamente $2500 \mu \mathrm{m}$ da superfície dos mesmos, concentrações baixas e/ou nulas de OD foram mensuradas. Significantes decréscimos de $\mathrm{pH}$ ocorreram na célula 1 no sentido meio líquido para o interior do biofilme e pequenos decréscimos de $\mathrm{pH}$ foram determinados na célula de fluxo 3 . No biofilme da célula 2 as variações de $\mathrm{OD}$ e de $\mathrm{pH}$ foram mais amenas.

Ao comparar os perfis de OD obtidos no $7^{\circ}$ dia (Figura 5.38) com os do $5^{\circ}$ dia (Figura 5.37), foram notados sensíveis aumentos das concentrações de OD nas camadas mais internas dos biofilmes aderidos nas três células. Com exceção da célula 3, os acréscimos das concentrações dos íons $\mathrm{NO}_{\mathrm{x}}{ }^{-} \mathrm{e}$ as diminuições das concentrações dos íons $\mathrm{NH}_{4}{ }^{+}$no sentido meio aquoso - biofilmes foram mais significativas quando comparadas às ocorridas no $2^{\circ}$ dia do experimento.

Verificou-se que no $8^{\circ}$ dia do experimento a difusão de oxigênio dissolvido foi maior ao longo das espessuras dos biofilmes das células de fluxo 1 e 3 do que a do biofilme aderido à superfície suporte da célula 2 (Figura 5.39). 


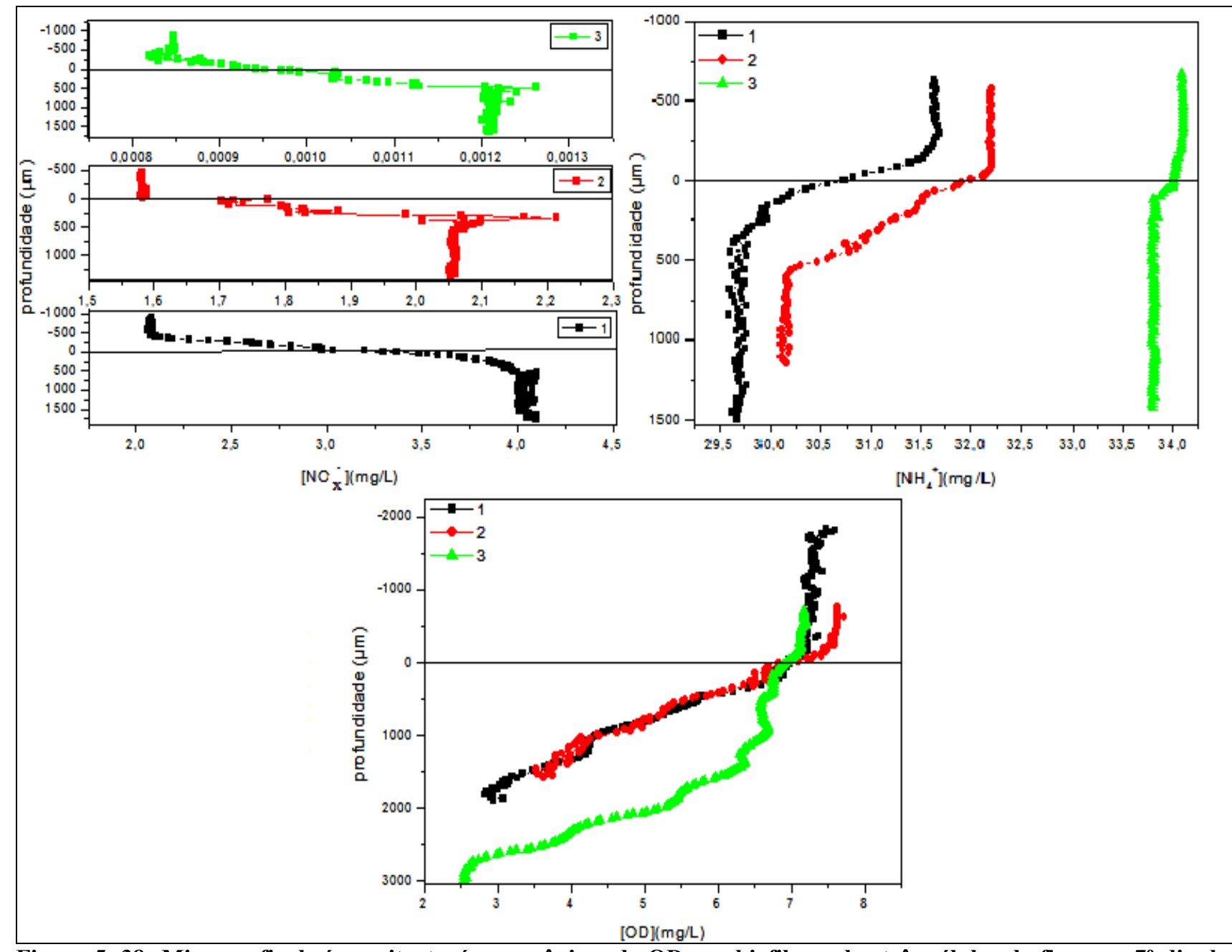

Figura 5. 38: Microperfis de íons nitrato, íons amônio e de OD nos biofilmes das três células de fluxo no $7^{\circ}$ dia do

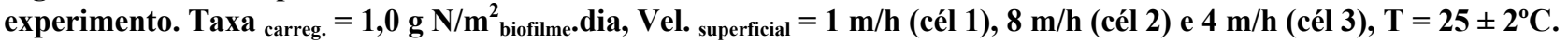

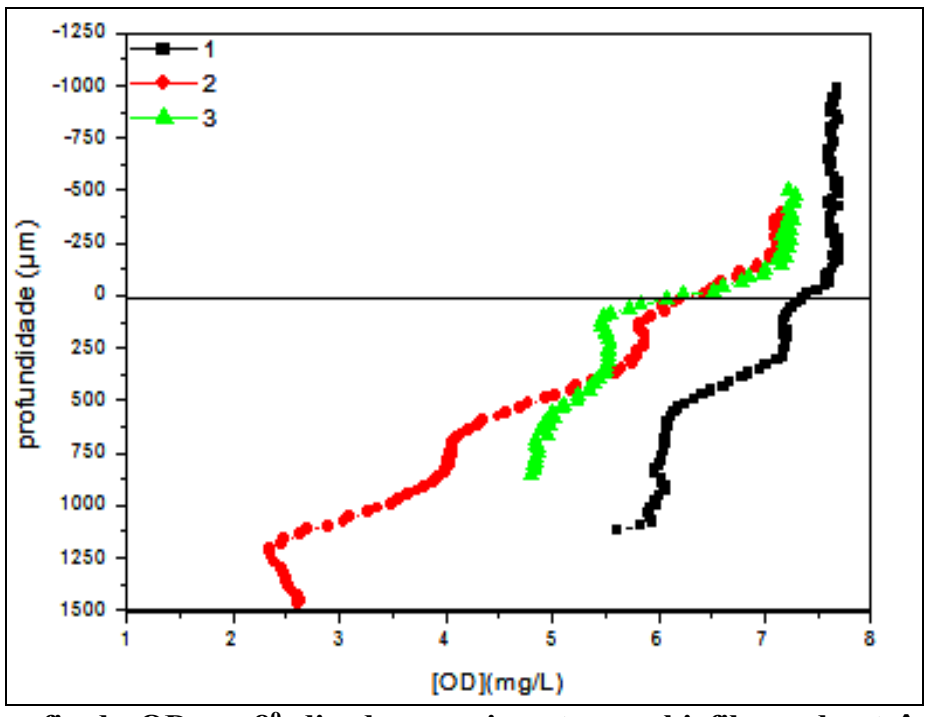

Figura 5. 39: Microperfis de OD no $8^{0}$ dia do experimento nos biofilmes das três células de fluxo. Taxa $_{\text {carreg. }}=1,0 \mathrm{~g} \mathrm{~N} / \mathrm{m}^{2}{ }_{\text {biofilme.dia, Vel. superficial }}=1 \mathrm{~m} / \mathrm{h}$ (cél 1), $8 \mathrm{~m} / \mathrm{h}$ (cél 2) e $4 \mathrm{~m} / \mathrm{h}\left(\right.$ cél 3), $\mathrm{T}=25 \pm 2^{\circ} \mathrm{C}$. 
Ao interpretar os perfis de concentração de OD obtidos via microssensores, conclui-se que os biofilmes apresentaram baixas concentrações de oxigênio dissolvido já no quinto dia de operação das células de fluxo, uma vez que estes se aproximaram de zero nas zonas que distavam de 2000-3500 $\mu \mathrm{m}$ das superfícies dos biofilmes. Foi suposto que tal fato tenha impossibilitado a ocorrência da nitrificação completa, pois a ação das bactérias oxidadoras de nitrito a nitrato foi novamente inibida, como no experimento anterior, pelas baixas concentrações de oxigênio dissolvido no interior do biofilme. Assim, supõe-se que a nitrificação via curta tenha acontecido.

Ainda relatando o observado nas análises das concentrações de oxigênio dissolvido realizadas com o microssensores de OD, verificou-se que, após o quinto dia do início do experimento, no qual as concentrações de OD chegaram a atingir o valor de zero nas zonas mais internas dos biofilmes, as concentrações das espécies em questão foram relativamente elevadas na totalidade do interior dos filmes microbianos. Tal acontecimento deveu-se provavelmente ao fato de que, após o consumo total do oxigênio no biofilme, o desprendimento do mesmo da sua superfície suporte ocorreu. Assim, depois do quinto dia de operação das células de fluxo, conjecturou-se que as concentrações de OD detectadas pelos microssensores foram referentes ao OD do meio líquido e não ao OD presente nas camadas internas dos biofilmes.

Mediante a análise dos microperfis de concentração dos íons $\mathrm{NO}_{\mathrm{x}}{ }^{-}$, a hipótese citada anteriormente alusiva a nitrificação via curta foi evidenciada, já que a concentração máxima de íons $\mathrm{NO}_{\mathrm{x}}{ }^{-}$determinada nas zonas que distavam de $2000 \mu \mathrm{m}$ da superfície do biofilme nas três células de fluxo foi de $5 \mathrm{mg} \mathrm{NO}_{3}{ }^{-} / \mathrm{L}$.

Ao analisar os microperfis de concentrações de íons amônio $\left(\mathrm{NH}_{4}{ }^{+}\right)$realizados no sexto dia de operação das três células de fluxo, observaram-se reduções das concentrações dos mesmos no sentido meio líquido - interior dos biofilmes, as quais foram provavelmente devidas às reações de oxidação dos íons amônio a íons nitrito.

Os microperfis de $\mathrm{pH}$ indicaram queda nos valores dos mesmos no interior dos biofilmes das três células de fluxo no $3^{\circ}$ e no $5^{\circ}$ dia de operação das mesmas. Este evento poderia ser considerado como consequência da redução dos valores de alcalinidade que existe quando o processo de nitrificação é promovido. Recorreu-se então aos resultados das análises físico-químicas realizadas no presente estudo, para verificação da veracidade das hipóteses levantadas mediante as análises dos microperfis de concentrações de $\mathrm{OD}$, íons $\mathrm{H}^{+}, \mathrm{NO}_{3}{ }^{-}, \mathrm{NO}_{2}{ }^{-} \mathrm{e} \mathrm{NH}_{4}{ }^{+}$obtidos por meio da aplicação de microssensores. 


\subsubsection{2- Resultados das análises físico-químicas}

Os resultados das análises físico-químicas estão apresentados nas Tabelas 5.10; 5.11; $5.12 \mathrm{e}$ 5.13:

Tabela 5. 10:Alcalinidade dos efluentes das três células de fluxo e do substrato sintético das mesmas.

\begin{tabular}{|c|c|c|c|c|}
\hline \multicolumn{4}{|c|}{ Alcalinidade $\left(\mathbf{m g C a C O}_{3} / \mathbf{L}\right)$} \\
\hline \hline Dia & Substrato sintético & cél.1 & cél.2 & cél.3 \\
\hline $\mathbf{2}^{\circ}$ & 252,0 & 135,7 & 128,4 & 136,1 \\
\hline $\mathbf{4}^{\circ}$ & 250,0 & 127,8 & 126,3 & 130,7 \\
\hline $\mathbf{6}^{\circ}$ & 270,0 & 138,0 & 61,6 & 82,2 \\
\hline
\end{tabular}

Tabela 5. 11: Valores de pH no afluente e nos efluentes das três células de fluxo.

\begin{tabular}{|c|c|c|c|c|}
\hline \multicolumn{5}{|c|}{ pH } \\
\hline \hline Dia & Substrato sintético & cél.1 & cél.2 & cél.3 \\
\hline $\mathbf{2}^{\mathbf{0}}$ & 7,9 & 7,4 & 7,3 & 7,3 \\
\hline $\mathbf{4}^{\mathbf{0}}$ & 7,6 & 7,3 & 7,1 & 7,2 \\
\hline $\mathbf{6}^{\mathbf{0}}$ & 6,8 & 7,0 & 7,0 & 7,2 \\
\hline
\end{tabular}

Tabela 5. 12: Concentrações de NTK $(\mathrm{mg} / \mathrm{L})$ do substrato sintético e dos efluentes das três células de fluxo.

\begin{tabular}{|c|c|c|c|c|}
\hline \multicolumn{5}{|c|}{ NTK (mg/L) } \\
\hline Dia & Substrato sintético & cél.1 & cél.2 & cél. 3 \\
\hline \hline $\mathbf{1}^{\mathbf{0}}$ & 35,0 & 17,1 & 88,3 & 39,0 \\
\hline $\mathbf{4}^{\mathbf{0}}$ & 38,0 & 41,3 & 22,9 & 39,0 \\
\hline $\mathbf{5}^{\mathbf{0}}$ & 41,0 & 37,8 & 24,0 & 26,3 \\
\hline $\mathbf{7}^{\mathbf{0}}$ & 37,0 & 32,0 & 33,2 & 30,9 \\
\hline
\end{tabular}

Tabela 5. 13: Concentrações de íons $\mathrm{NO}_{2}^{-}(\mathrm{mg} / \mathrm{L})$ dos efluentes das três células de fluxo.

\begin{tabular}{|c|c|c|c|}
\hline \multicolumn{4}{|c|}{$\mathrm{NO}_{2}^{-}(\mathrm{mg} / \mathrm{L})$} \\
\hline Dia & cél.1 & cél.2 & cél.3 \\
\hline $1^{\circ}$ & 0,06 & 0,26 & 0,10 \\
\hline $2^{\circ}$ & 0,08 & 0,37 & 0,00 \\
\hline $5^{\circ}$ & 0,70 & 0,48 & 0,50 \\
\hline $6^{\circ}$ & 1,00 & 0,78 & 0,00 \\
\hline $7^{\circ}$ & 1,90 & 1,48 & 0,00 \\
\hline
\end{tabular}

Houve consumo de alcalinidade nas três células de fluxo no decorrer do experimento. Entretanto esses foram seguidos de diminuição de $\mathrm{pH}$ apenas nas células de fluxo 1 e 2 , já que na célula 3 o oposto ocorreu (aumento de $\mathrm{pH}$ ).

Analisando-se as Tabelas 5.12 e 5.13 foi observado que na célula de fluxo 1, ocorreu consumo de NTK no $1^{\circ} ; 5^{\circ}$ e $7^{\circ}$ dia do experimento, contudo tais consumos não foram devidos a conversão dos íons $\mathrm{NH}_{4}^{+}$a nitrito e posteriormente a nitrato, visto que as concentrações de íons nitrito originadas foram muito baixas aliadas ao fato de que as concentrações de íons nitrato determinadas foram insignificantes, por isso não constam na tabela. Pequena produção de NTK foi observada no $4^{\circ}$ dia do experimento. A DQO do afluente das células de fluxo possuía valor equivalente à $105 \pm 15 \mathrm{mg} / \mathrm{L}$. Foi constatado através das análises das mesmas no efluente da célula de fluxo em questão realizadas no 
primeiro $(\mathrm{DQO}=107 \mathrm{mg} / \mathrm{L})$ e no último dia $(\mathrm{DQO}=34 \mathrm{mg} / \mathrm{L})$ do experimento que houve remoção da matéria orgânica.

A célula de fluxo 2 comportou-se de forma similar à 1, pois também foram detectadas reduções nos valores de DQO (103 e $21 \mathrm{mg} / \mathrm{L}$ no primeiro e último dia do experimento), flutuações dos valores de NTK (incluindo consumo e produção do mesmo), e concentrações quase que insignificantes de íons nitrito ao longo dos dias de operação da mesma.

A célula de fluxo 3 apresentou comportamentos semelhantes às demais, uma vez que nesta houve variação aleatória de NTK e concentrações desprezíveis de íons nitrito foram determinadas no efluente da mesma. Uma particularidade concernente a essa célula de fluxo recaiu no fato de que foi verificado aumento no valor da DQO (=700 mg/L) no último dia de operação da mesma. Presumiu-se, todavia que o aumento no valor da DQO tenha sido devido à presença de biomassa suspensa na amostra coletada para análise em questão.

Portanto, conjecturou-se através desses resultados que o processo de nitrificação total não foi promovido em nenhuma das células de fluxo e que possivelmente a nitrificação via curta ocorreu apenas nas células 1 e 2 nas quais se detectou a presença de concentrações reduzidas de íons nitrito no meio.

\subsubsection{3- Resultados - Microssensores e análises físico-químicas}

Reunindo-se os resultados obtidos mediante uso dos microssensores com os das análises físicoquímicas, as subsequentes conclusões foram tiradas:

Os microssensores de $\mathrm{pH}$ mostraram-se sensíveis e seletivos aos seus analitos, já que os valores obtidos mediante o uso destes foram similares aos alcançados nas análises físico-químicas feitas com o uso de macroeletrodo de $\mathrm{pH}$ (Tabela 5.14).

Tabela 5. 14: Valores de pH obtidos por meio de macroeletrodos e de microeletrodos de pH.

\begin{tabular}{|c|c|c|}
\hline \multicolumn{3}{|c|}{$\mathbf{p H}$} \\
\hline $\begin{array}{c}\text { Célula } \\
\text { de Fluxo }\end{array}$ & $\begin{array}{c}\text { Macroeletrodo } \\
\left.\mathbf{( 2}^{\mathbf{}} \mathbf{d i a}\right)\end{array}$ & $\begin{array}{c}\text { Microeletrodo } \\
\left.\mathbf{( 2}^{\mathbf{o}} \mathbf{d i a}\right)\end{array}$ \\
\hline \hline 1 & 7,4 & 7,4 \\
\hline 2 & 7,3 & 7,2 \\
\hline 3 & 7,3 & 7,3 \\
\hline
\end{tabular}

Quanto aos microssensores de íons $\mathrm{NO}_{\mathrm{x}}{ }^{-}$foi verificado que os mesmos continuaram a detectar os íons nitrato e nitrito. Tal afirmação foi feita a partir dos seguintes fatos: no presente experimento as concentrações de íons nitrato mensuradas por meio das análises físico-químicas apresentaram valores 
insignificantes; concentrações similares às dos íons nitrito verificadas mediante análises físico-químicas foram determinadas no meio líquido das células de fluxo através da aplicação dos microssensores de detecção de íons $\mathrm{NO}_{\mathrm{x}}^{-}$.

As concentrações dos íons $\mathrm{NO}_{\mathrm{x}}{ }^{-}$determinadas no meio líquido das células de fluxo por meio do emprego de microssensores comparadas com as de nitrito reveladas através das análise físico-químicas (FIA-FLow Injection Analysis) foram exibidas na Tabela 5.15.

Tabela 5. 15: Valores de concentrações de $\mathrm{NO}_{\mathrm{x}}^{-}$obtidos por meio de microeletrodos e da técnica FIA.

\begin{tabular}{|c|c|c|c|c|}
\hline $\begin{array}{l}\text { Célula } \\
\text { de Fluxo }\end{array}$ & $\begin{array}{l}\text { FIA - } 2^{0} \text { dia } \\
\mathrm{NO}_{2}^{-}(\mathrm{mg} / \mathrm{L})\end{array}$ & $\begin{array}{c}\text { Microeletrodo- } 2^{0} \text { dia } \\
\text { NO}_{x}^{-}(\mathrm{mg} / \mathrm{L})\end{array}$ & $\begin{array}{c}\text { FIA- } 7^{0} \text { dia } \\
\text { NO }_{2}^{-}(\mathrm{mg} / \mathrm{L})\end{array}$ & $\begin{array}{c}\text { Microeletrodo } 7^{0} \text { dia } \\
\mathrm{NO}_{\mathrm{x}}^{-}(\mathrm{mg} / \mathrm{L})\end{array}$ \\
\hline 1 & 0,06 & 0,06 & 1,90 & 1,90 \\
\hline 2 & 0,26 & 0,40 & 1,48 & 1,58 \\
\hline 3 & 0,10 & $7,60 \cdot 10^{-3}$ & 0,00 & $8,00 \cdot 10^{-5}$ \\
\hline
\end{tabular}

Foi verificado, a partir da Tabela 5.15, que a maior parte dos valores das concentrações de íons $\mathrm{NO}_{\mathrm{x}}{ }^{-}$mensurados mediante aplicação de microssensores, não se encontraram dentro da faixa de detecção dos microeletrodos destinados para tal análise $\left(10^{-5} \mathrm{~mol} / \mathrm{L}\right.$ ou $\left.0,62 \mathrm{mg} / \mathrm{L}\right)$. Sendo assim, apesar de os resultados obtidos via microssensores e análises físico-químicas terem se mostrado bastante similares, nesse caso as concentrações de $\mathrm{NO}_{\mathrm{x}}{ }^{-}$determinadas através das últimas conferem maior confiabilidade.

Abordando-se agora os microeletrodos destinados a mensuração de concentração de íons amônio em biofilmes, verificou-se que no segundo dia de operação das células de fluxo, as concentrações dos mesmos obtidas no meio líquido das três células de fluxo situaram-se na faixa de 39 a $50 \mathrm{mg} \mathrm{NH}{ }_{4}^{+} / \mathrm{L}$ nas três células. Infelizmente, estes valores não puderam ser comparados com os resultados das análises físico-químicas visto que neste dia não foram realizadas análises de NTK dos efluentes das células.

Os resultados das análises de NTK do sétimo dia de operação das células de fluxo foram então confrontados com os microperfis de íons amônio obtidos neste dia. A Tabela 5.16 contém as concentrações NTK determinadas por análise físico-química e na Figura 5.40 as linhas vermelhas indicam o valor das concentrações de íons amônio mensuradas pelos microssensores no meio líquido das células de fluxo.

Tabela 5. 16:Concentrações de NTK determinadas por análise físico-químicas

\begin{tabular}{|c|c|}
\hline Célula de Fluxo & $\mathrm{NTK}(\mathrm{mg} / \mathrm{L})\left(7^{0} \mathrm{dia}\right)$ \\
\hline 1 & 30,9 \\
\hline 2 & 32,0 \\
\hline 3 & 33,2 \\
\hline
\end{tabular}




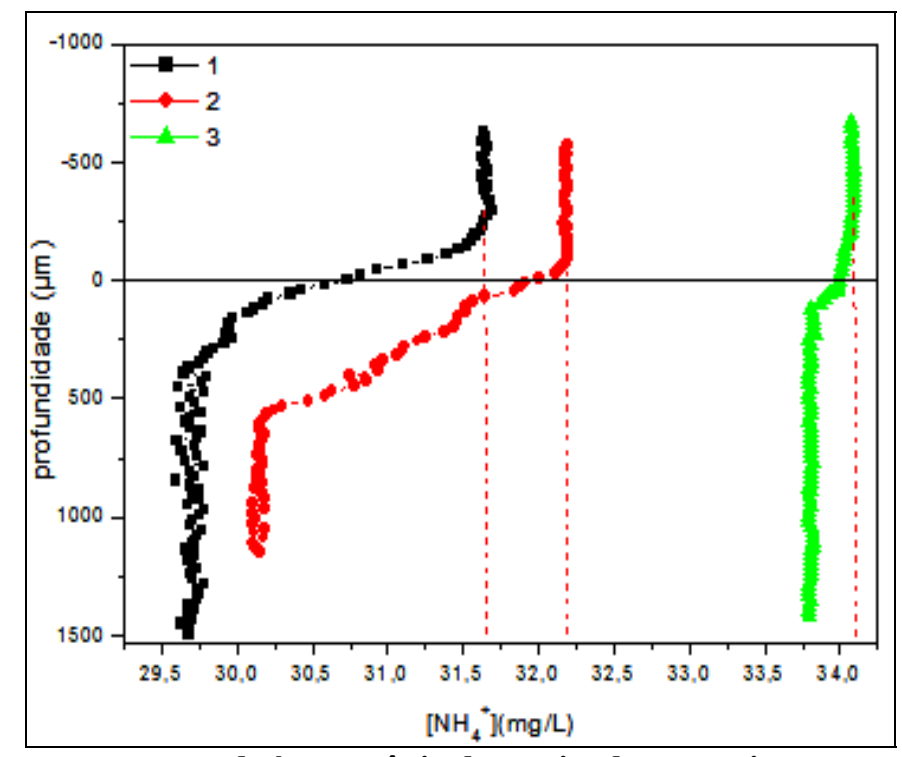

Figura 5. 40: Valores das concentrações de íons amônio determinadas por microssensores no $7^{0}$ dia do experimento. Taxa $_{\text {carreg. }}=1,0 \mathrm{~g} \mathrm{~N} / \mathrm{m}^{2}{ }_{\text {biofilme.dia, Vel. superficial }}=1 \mathrm{~m} / \mathrm{h}$ (cél 1), $8 \mathrm{~m} / \mathrm{h}$ (cél 2) e $4 \mathrm{~m} / \mathrm{h}$ (cél 3), $\mathrm{T}=25 \pm 2^{\circ} \mathrm{C}$.

A similaridade dos valores de tais concentrações mensuradas mediante o emprego de microletrodos de íons amônio e através das análises físico-químicas, em conjunção com o resultado do teste de seletividade dos microssensores de $\mathrm{NH}_{4}{ }^{+}$detalhado na Seção 5.2.2, consistiram em fatos que comprovaram a seletividade e eficiência desses microssensores.

\subsubsection{4- Conclusões do experimento}

Combinando-se os resultados obtidos mediante aplicação dos microssensores de OD, de íons $\mathrm{NO}_{\mathrm{x}}^{-}$, amônio $\left(\mathrm{NH}_{4}^{+}\right)$e $\mathrm{H}^{+}(\mathrm{pH})$ com os dados encontrados a partir das análises físico-químicas, conclui-se que o objetivo do experimento, que era o de acompanhar o desenvolvimento de biofilmes aeróbios nitrificantes em reatores do tipo célula de fluxo, foi alcançado em partes, visto que os microssensores se mostraram eficazes no acompanhamento do crescimento de biofilmes e na verificação das difusões das espécies químicas em questão ao longo das espessuras dos mesmos. Entretanto, através da junção dos resultados obtidos pelos microssensores de íons $\mathrm{NO}_{\mathrm{x}}{ }^{-}$e amônio, com os dados das determinações de NTK e de íons nitrato e nitrito dos efluentes das três células, foi suposto que a nitrificação total não foi promovida no interior dos biofilmes aderidos nas superfícies das células de fluxo. De acordo com as baixas concentrações de íons nitrito verificadas, concluiu-se que a nitrificação via curta ocorreu nas células de fluxo 1 e 2, porém de forma inibida, já que baixas concentrações desses íons foram mensuradas tanto mediante o emprego de análises físico-químicas como através do uso dos microssensores. 
Conclui-se, portanto que a razão pela qual a nitrificação não foi promovida nos biofilmes formados nas células de fluxo foi a de que a taxa de carregamento de $1,0 \mathrm{~g} \mathrm{~N} / \mathrm{m}^{2}$.dia aplicado nas mesmas foi muito alta em contraste com as concentrações de OD que decresceram muito rápido, em um período de tempo relativamente pequeno. Deste modo, a quantidade de bactérias nitrificantes desenvolvida não foi suficiente para assimilar a quantidade de nitrogênio presente no meio.

\subsection{5- Experimento C}

\subsubsection{1- Resultados das análises via microssensores}

Os microperfis de oxigênio dissolvido, $\mathrm{pH}$, de íons amônio $\left(\mathrm{NH}_{4}{ }^{+}\right)$e de $\mathrm{NO}_{\mathrm{x}}{ }^{-}$obtidos no $1^{\circ}$ e no $2^{\circ}$ dia de operação das células de fluxo deste experimento encontram-se nas Figuras 5.41 e 5.42:

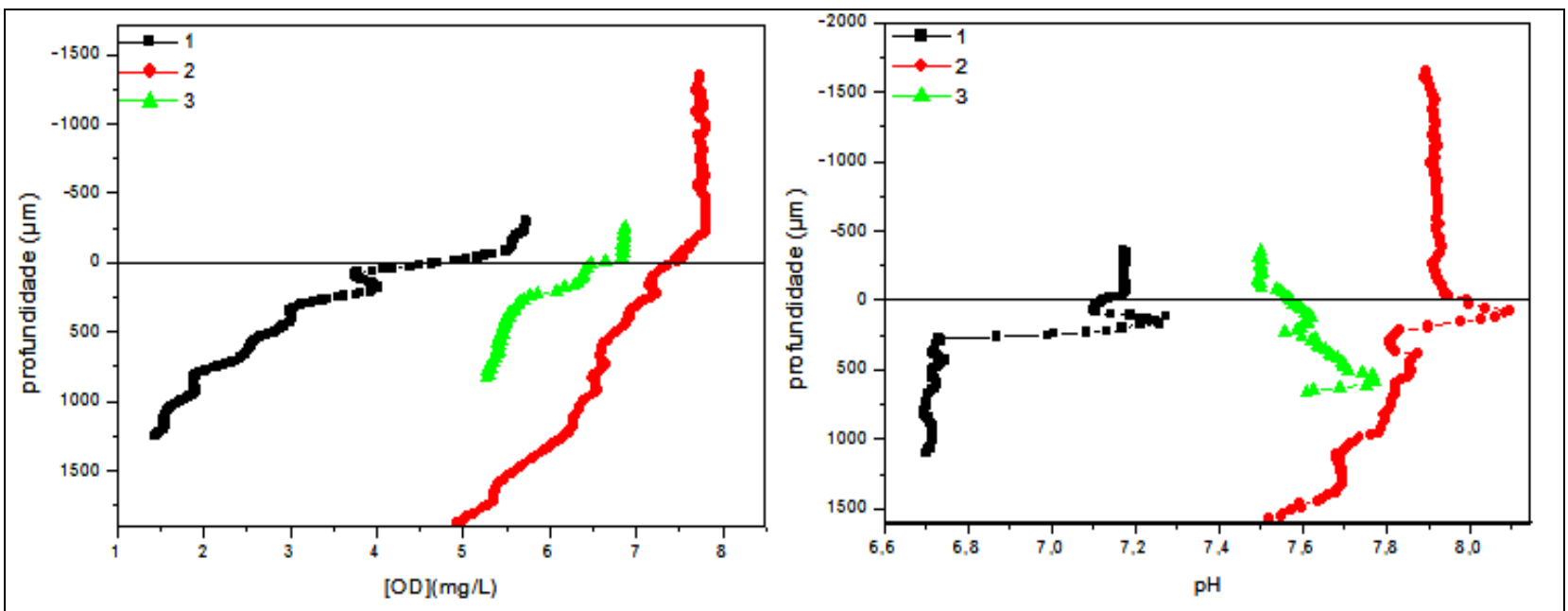

Figura 5. 41: Microperfis de oxigênio dissolvido e de $\mathrm{pH}$ nas três células de fluxo no $1^{\circ}$ dia do experimento.

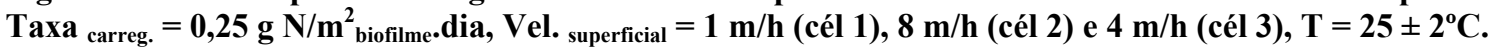
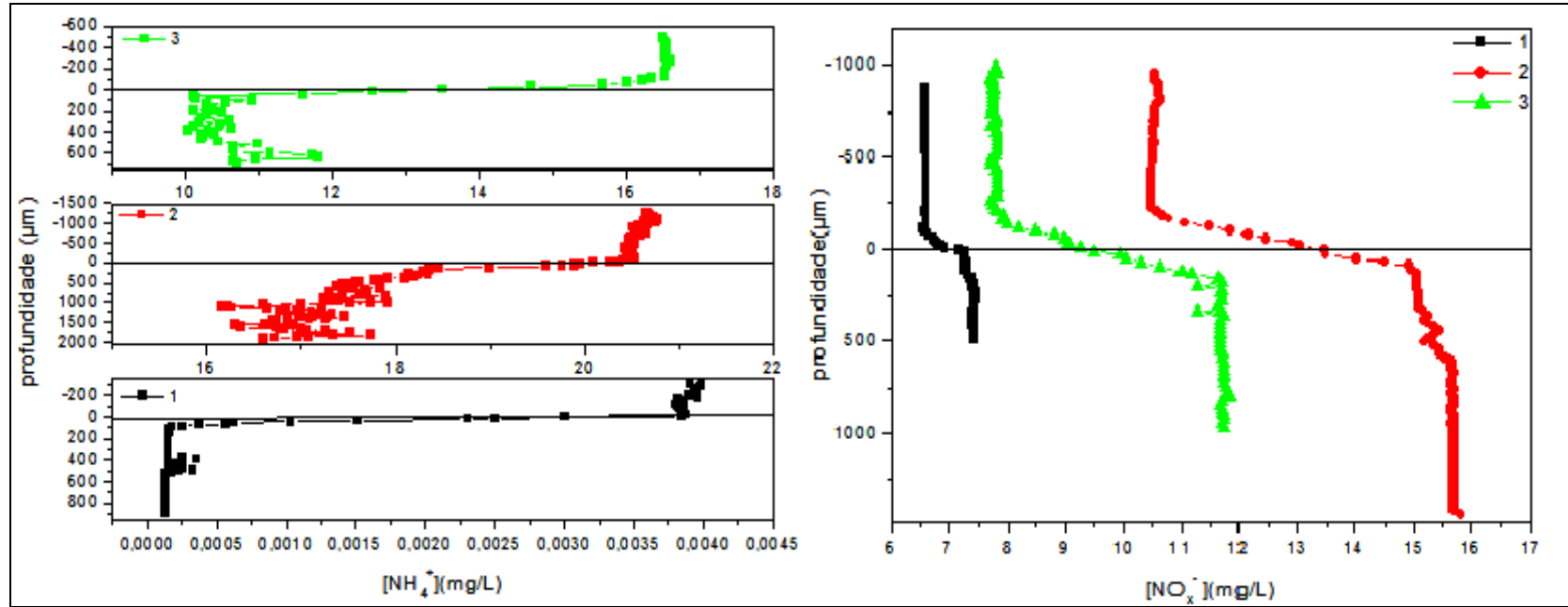

Figura 5. 42: Microperfis de íons amônio $\left(\mathrm{NH}_{4}^{+}\right)$e íons $\mathrm{NO}_{\mathrm{x}}^{-}$nas três células de fluxo no $2^{\circ}$ dia do experimento.

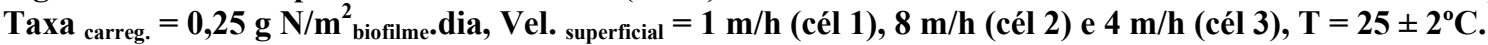


Observou-se, a partir dos microperfis obtidos no primeiro dia de operação das células de fluxo, que baixas concentrações de OD foram detectadas nas zonas mais internas do biofilme formado na célula de fluxo 1, as quais distavam de $1200 \mu \mathrm{m}$ da superfície do mesmo. As concentrações de OD mensuradas ao longo dos biofilmes desenvolvidos nas células de fluxo 2 e 3 se encontraram na faixa de 5,0 a 7,5 mg OD/L. Foi suposto que os baixos valores das concentrações de OD medidos na célula de fluxo 1 foram devidos a presença de flocos do lodo de inóculo na superfície da mesma.

A redução dos valores de pH ocorreu nas células de fluxo 1 e 2 no sentido meio líquido biofilme, enquanto que um pequeno acréscimo do mesmo foi observado na célula 3 .

Com relação aos valores das concentrações dos íons $\mathrm{NH}_{4}{ }^{+}$e de $\mathrm{NO}_{\mathrm{x}}{ }^{-}$foi constatado que houve redução dos primeiros e aumento dos segundos, na direção meio aquoso para o interior do biofilme das três células. Notou-se também, por meio de tais microperfis, que as concentrações de íons amônio tanto no meio líquido quanto no biofilme formado na célula 1, apresentaram valores muito baixos e que como consequência desse fato neste mesmo biofilme, o aumento das concentrações de íons $\mathrm{NO}_{\mathrm{x}}{ }^{-}$foi inferior aos ocorridos nos biofilmes das outras células de fluxo.

Nas Figuras 5.43 e 5.44 estão ilustrados os perfis de $\mathrm{OD}$, $\mathrm{pH}$, íons amônio e $\mathrm{NO}_{\mathrm{x}}{ }^{-}$obtidos no $3^{\circ} \mathrm{e}$ $4^{\mathrm{o}}$ dia do experimento.

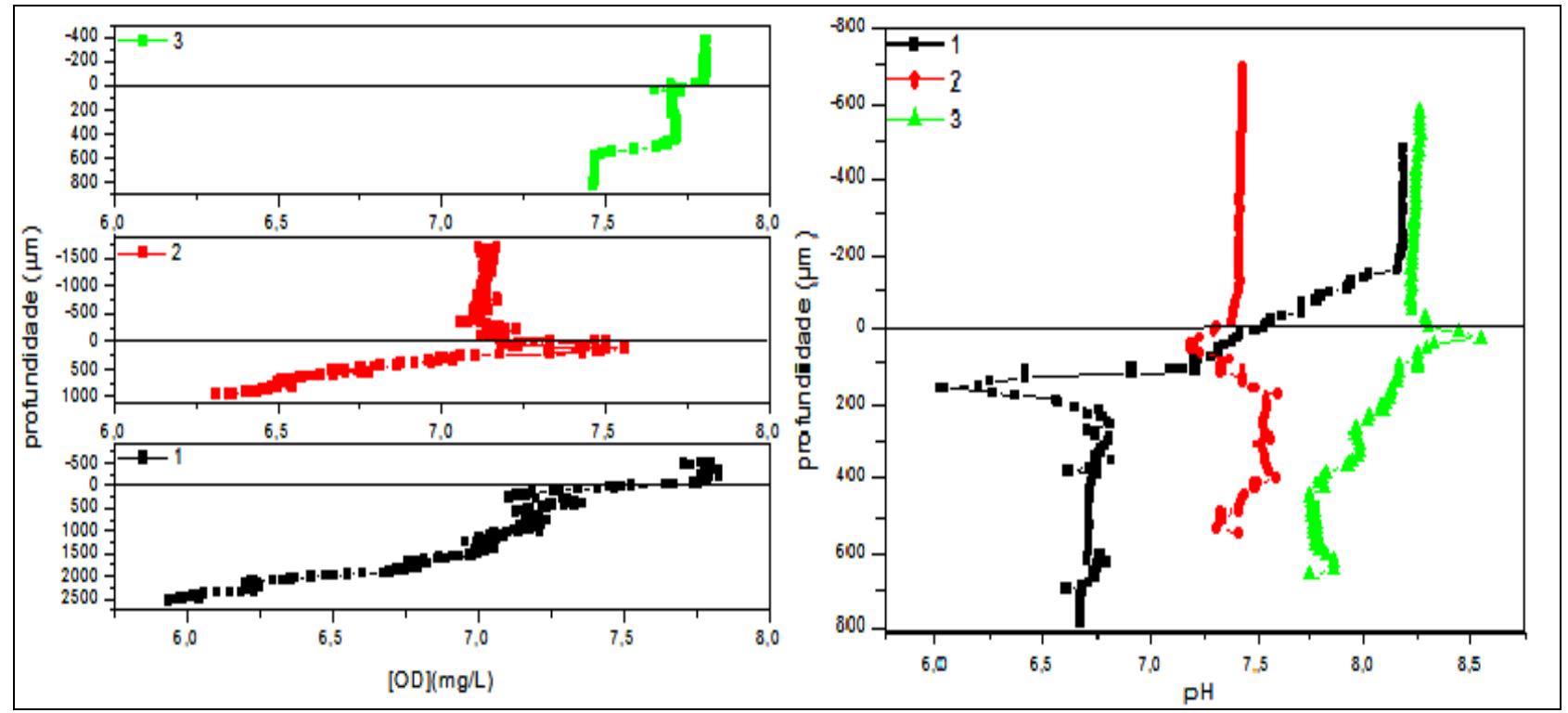

Figura 5. 43: Microperfis de oxigênio dissolvido e de $\mathrm{pH}$ das três células de fluxo no $3^{\circ}$ dia do experimento. Taxa $_{\text {carreg. }}=0,25 \mathrm{~g} \mathrm{~N} / \mathrm{m}_{\text {biofilme.dia, Vel. superficial }}^{2} 1 \mathrm{~m} / \mathrm{h}$ (cél 1), $8 \mathrm{~m} / \mathrm{h}$ (cél 2) e $4 \mathrm{~m} / \mathrm{h}$ (cél 3), T= $25 \pm 2^{\circ} \mathrm{C}$. 

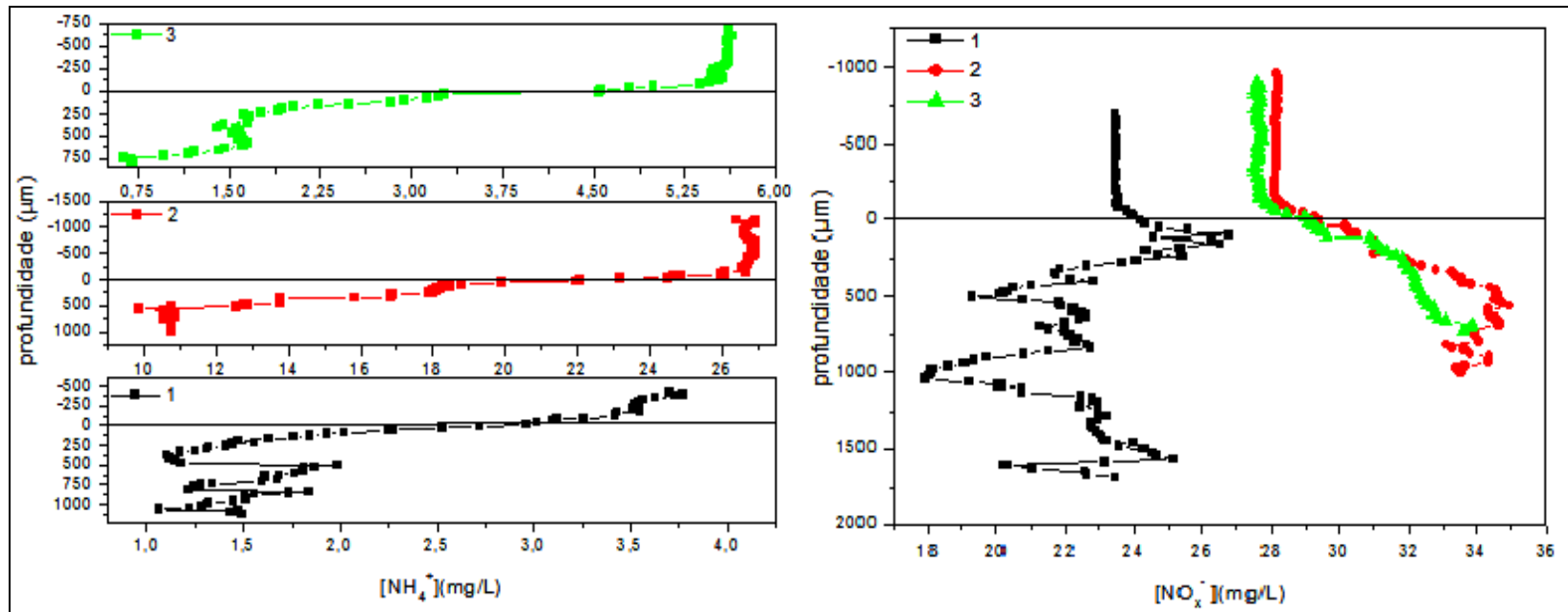

Figura 5. 44: Microperfis de íons amônio e de íons $\mathrm{NO}_{\mathrm{x}}^{-}$dos biofilmes das três células de fluxo no $4^{\circ}$ dia do experimento. Taxa ${ }_{\text {carreg. }}=0,25 \mathrm{~g} \mathrm{~N} / \mathrm{m}^{2}{ }_{\text {biofilme.dia, Vel. } \text { superficial }}=1 \mathrm{~m} / \mathrm{h}($ cél 1$), 8 \mathrm{~m} / \mathrm{h}\left(\right.$ cél 2) e $4 \mathrm{~m} / \mathrm{h}($ cél 3$), T=25 \pm 2^{\circ} \mathrm{C}$.

Por meio dos perfis levantados foi constatado que as concentrações de OD no interior dos biofilmes das três células se situaram dentro do intervalo de 6,0 a 7,7 mg OD/L. Os valores de $\mathrm{pH}$ detectados nas células 1 e 3 diminuíram em direção ao biofilme enquanto que na célula 2 houve um sensível aumento dos valores da variável em questão na mesma direção.

Reduções das concentrações dos íons amônio do meio aquoso para o filme microbiano foram verificadas nas três células de fluxo operadas sendo que essas, com exceção da célula 1, foram seguidas de aumento das concentrações dos íons $\mathrm{NO}_{\mathrm{x}}{ }^{-}$no mesmo sentido (meio aquoso- biofilme). Foi verificado também que as concentrações dos íons $\mathrm{NO}_{\mathrm{x}}{ }^{-}$no meio líquido das três células de fluxo apresentaram valores superiores aos mesmos mensurados no $2^{\circ}$ dia do ensaio.

Os microperfis das mesmas espécies químicas, monitoradas nos dias anteriores, obtidos no $5^{\circ} \mathrm{e}$ no $6^{\circ}$ dia do ensaio encontram-se presentes nas Figuras 5.45 e 5.46.
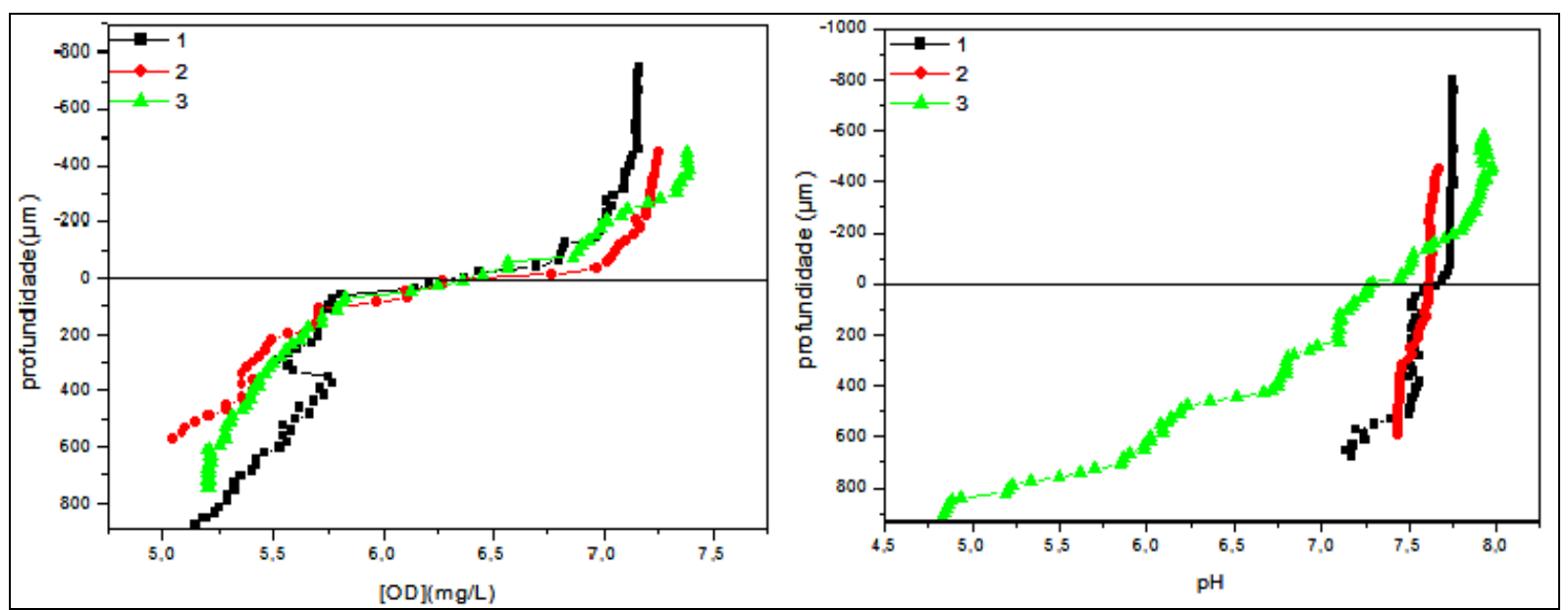

Figura 5. 45: Perfis de OD e de $\mathrm{pH}$ dos biofilmes das três células de fluxo no $5^{\circ}$ dia do experimento. Taxa $_{\text {carreg. }}=0,25 \mathrm{~g} \mathrm{~N} / \mathrm{m}^{2}$ biofilme.dia, Vel. superficial $=1 \mathrm{~m} / \mathrm{h}$ (cél 1), $8 \mathrm{~m} / \mathrm{h}$ (cél 2) e $4 \mathrm{~m} / \mathrm{h}$ (cél 3), T= $25 \pm 2^{\circ} \mathrm{C}$. 


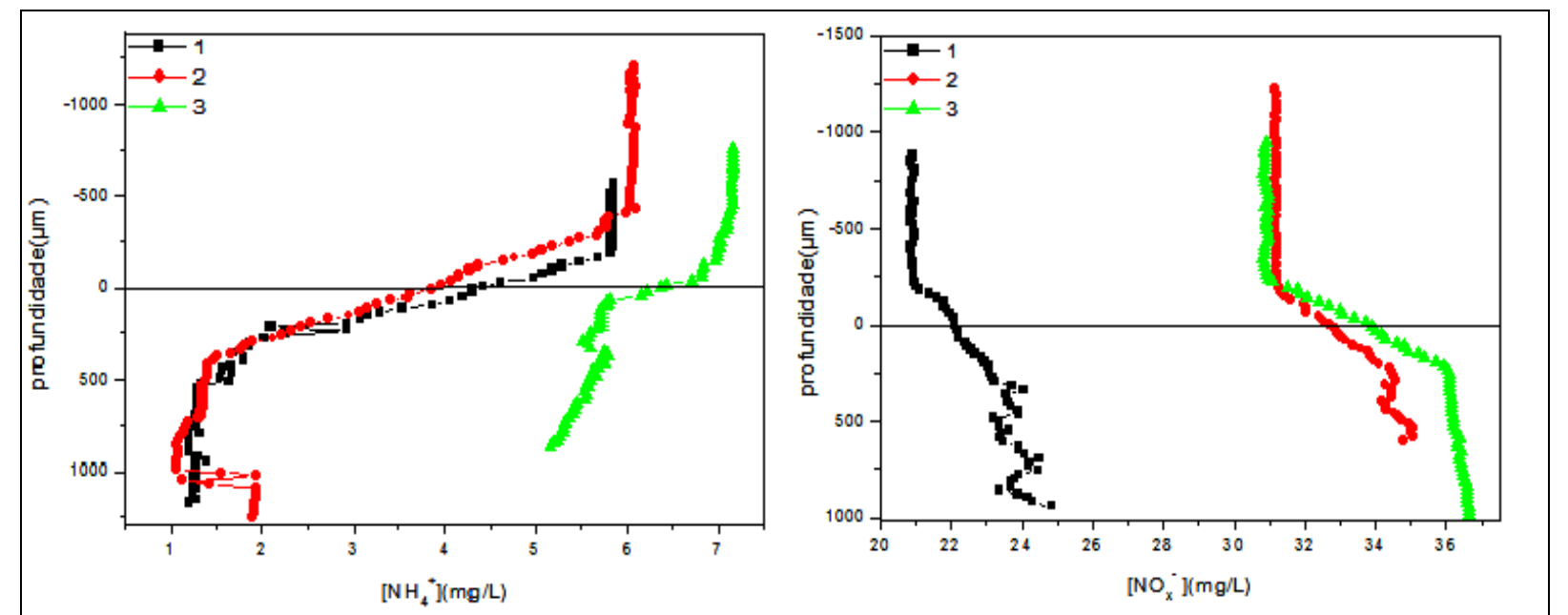

Figura 5. 46: Perfis de íons $\mathrm{NH}_{4}^{+}$e de íons $\mathrm{NO}_{\mathrm{x}}^{-}$dos biofilmes das três células de fluxo no $6^{\circ}$ dia do experimento.

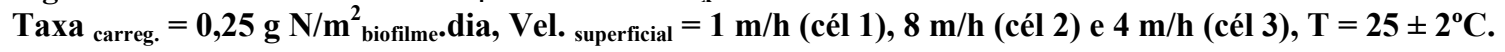

Os perfis de OD obtidos nas três células de fluxos apresentaram bastante semelhança entre si, sendo que nesses as concentrações de OD se situaram dentro do faixa de 5,0 a 6,2 no interior dos biofilmes. Por meio dos microperfis de $\mathrm{pH}$ foi verificado que apenas na célula 3 houve uma considerável redução dos valores de $\mathrm{pH}$ no sentido meio líquido - biofilme.

Decréscimos das concentrações dos íons $\mathrm{NH}_{4}{ }^{+}$seguidos de aumentos das concentrações dos íons $\mathrm{NO}_{\mathrm{x}}{ }^{-}$foram verificados nas três células de fluxo. Constatou-se também que altas concentrações dos íons $\mathrm{NO}_{\mathrm{x}}{ }^{-}$no meio aquoso das três células de fluxo foram novamente mensuradas, similares as do $4^{\circ}$ dia do experimento.

Os perfis de concentrações de $\mathrm{OD}, \mathrm{H}^{+}, \mathrm{NH}_{4}^{+}$e $\mathrm{NO}_{\mathrm{x}}{ }^{-}$obtidos nos dois últimos dias do experimento encontram-se ilustrados nas Figuras 5.47 e 5.48 :

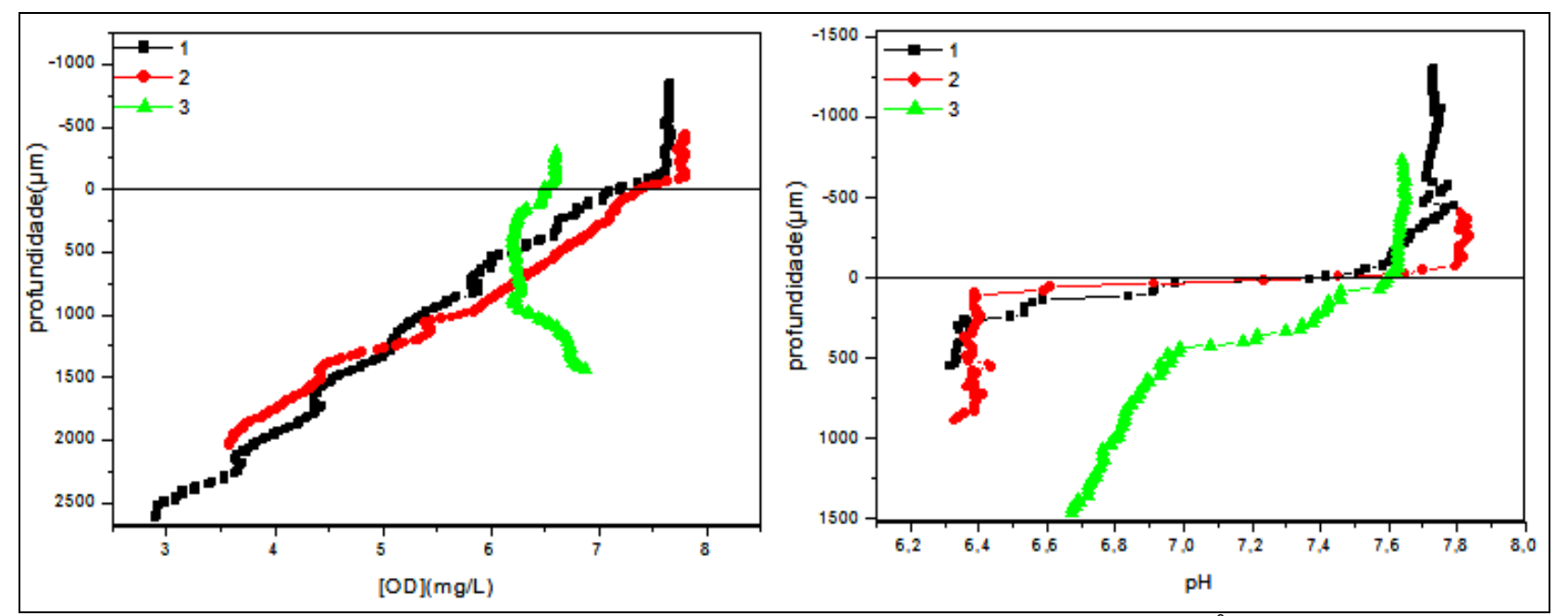

Figura 5. 47: Perfis de OD e de pH dos biofilmes das três células de fluxo no $7^{\circ}$ dia do experimento. Taxa $_{\text {carreg. }}=0,25 \mathrm{~g} \mathrm{~N} / \mathrm{m}_{\text {biofilme.dia, Vel. superficial }}^{2} 1 \mathrm{~m} / \mathrm{h}$ (cél 1), $8 \mathrm{~m} / \mathrm{h}$ (cél 2) e $4 \mathrm{~m} / \mathrm{h}$ (cél 3), $\mathrm{T}=25 \pm 2^{\circ} \mathrm{C}$. 


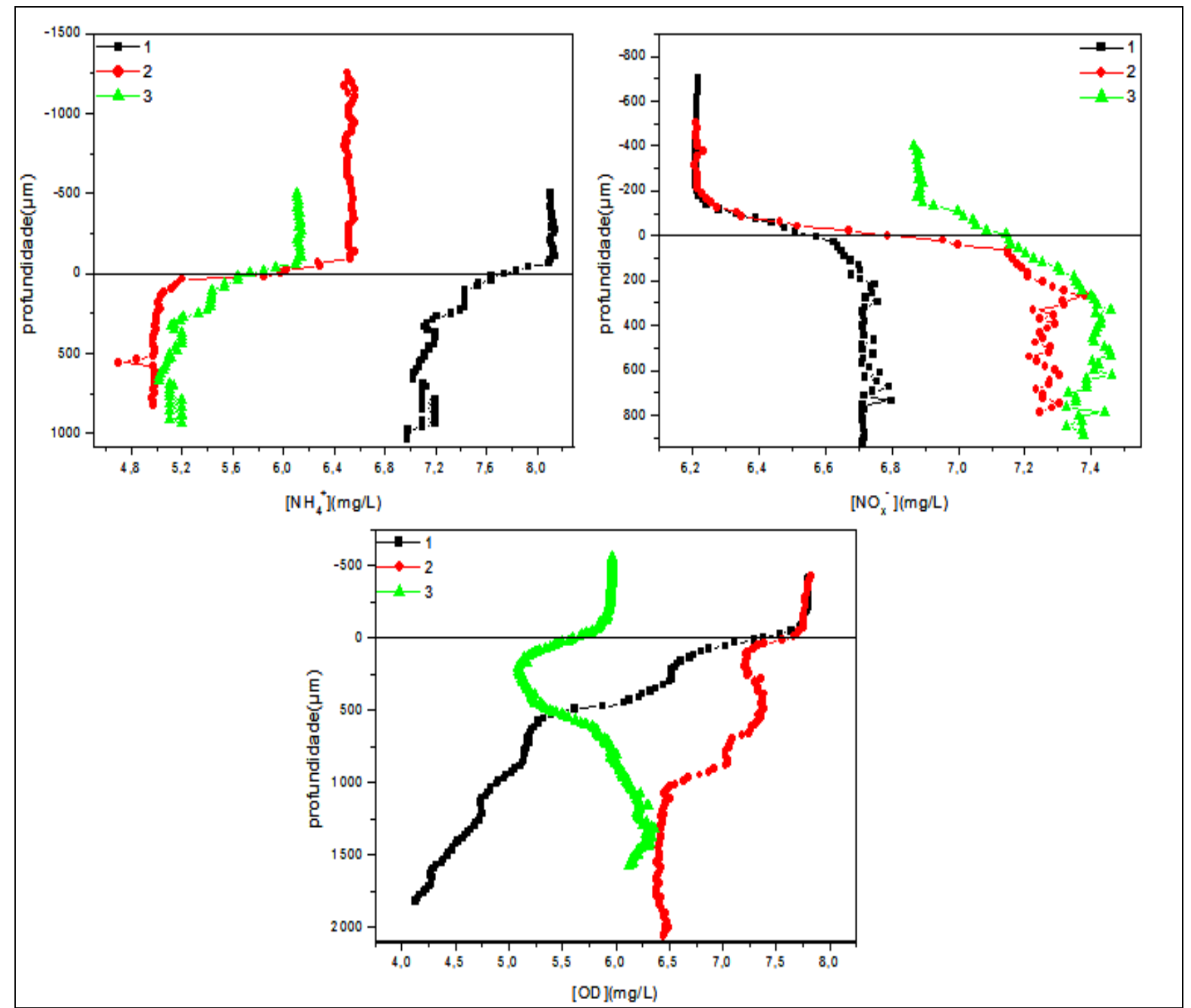

Figura 5. 48: Perfis de $\mathrm{NH}_{4}^{+}$, íons $\mathrm{NO}_{x}^{-}$e de OD dos biofilmes das três células de fluxo, no $8^{\circ}$ dia do experimento. Taxa $_{\text {carreg. }}=0,25 \mathrm{~g} \mathrm{~N} / \mathrm{m}^{2}{ }_{\text {biofilme.dia, Vel. }}$ superficial $=1 \mathrm{~m} / \mathrm{h}$ (cél 1), $8 \mathrm{~m} / \mathrm{h}$ (cél 2) e $4 \mathrm{~m} / \mathrm{h}\left(\right.$ cél 3), $\mathrm{T}=25 \pm 2^{\circ} \mathrm{C}$.

Baixas concentrações de OD (3,0 a 3,5 $\mathrm{mg}$ OD/L) foram mensuradas nas zonas mais profundas dos biofilmes formados na superfície suporte das células de fluxo 1 e 2 no $7^{\circ}$ dia do experimento. Diminuições dos valores de pH foram verificados nesse dia nas três células de fluxo, na direção meio aquoso para o interior dos biofilmes desenvolvidos nas mesmas. Constatou-se também que as reduções das concentrações dos íons $\mathrm{NH}_{4}{ }^{+}$foram acompanhadas de acréscimo das concentrações de íons $\mathrm{NO}_{\mathrm{x}}{ }^{-}$ nos biofilmes presentes nas três células de fluxo.

Os microperfis de OD obtidos no último dia do experimento indicaram aumento das concentrações de OD nas camadas mais internas dos biofilmes, principalmente na célula de fluxo 2 . 


\subsubsection{2- Resultados das análises físico-químicas}

As Figuras 5.49, 5.50 e 5.51 contêm os resultados das análises físico-químicas concernentes a alcalinidade, pH e NTK do afluente e efluente das três células de fluxo realizadas no presente ensaio.

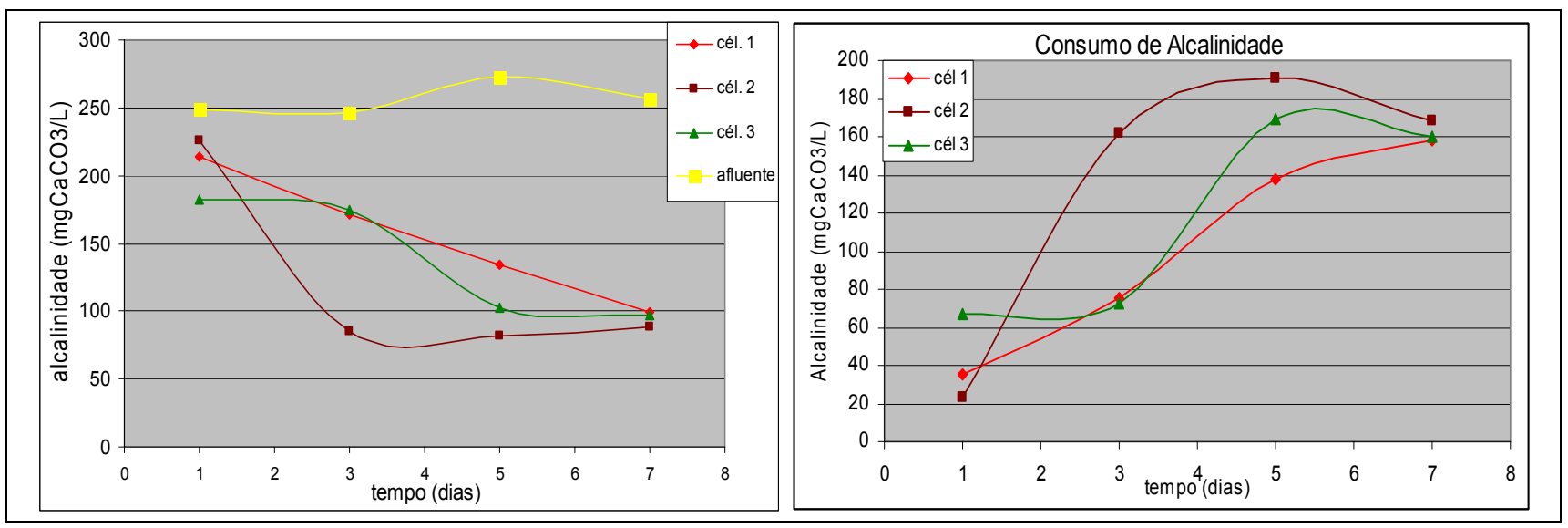

Figura 5. 49: Alcalinidade do afluente e dos efluentes das três células de fluxo (1; 2 e 3) (à esquerda). Consumo de alcalinidade das três células de fluxo (à direita). Taxa carreg. $=0,25 \mathrm{~g} \mathrm{~N} / \mathrm{m}^{2}{ }_{\text {biofilme.dia, Vel. superficial }}=1 \mathrm{~m} / \mathrm{h}$ (cél 1$), 8 \mathrm{~m} / \mathrm{h}$ (cél 2) e $4 \mathrm{~m} / \mathrm{h}$ (cél 3), $\mathrm{T}=25 \pm 2^{\circ} \mathrm{C}$.

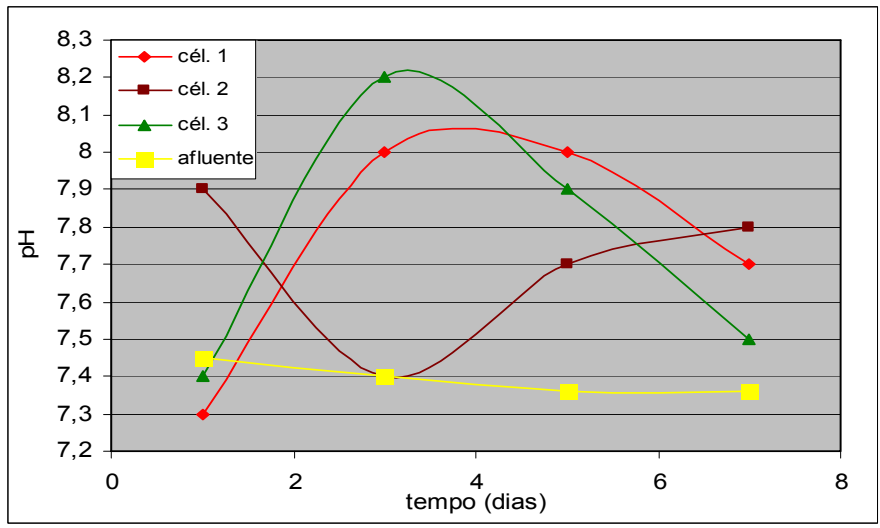

Figura 5. 50: Valores de $\mathrm{pH}$ no afluente e nos efluentes das três células de fluxo $(1 ; 2$ e 3$)$ Taxa ${ }_{\text {carreg. }}=0,25 \mathrm{~g} \mathrm{~N} / \mathrm{m}^{2}{ }_{\text {biofilme.dia, Vel. superficial }}=1 \mathrm{~m} / \mathrm{h}$ (cél 1), $8 \mathrm{~m} / \mathrm{h}$ (cél 2) e $4 \mathrm{~m} / \mathrm{h}$ (cél 3), $\mathrm{T}=25 \pm 2^{\circ} \mathrm{C}$.

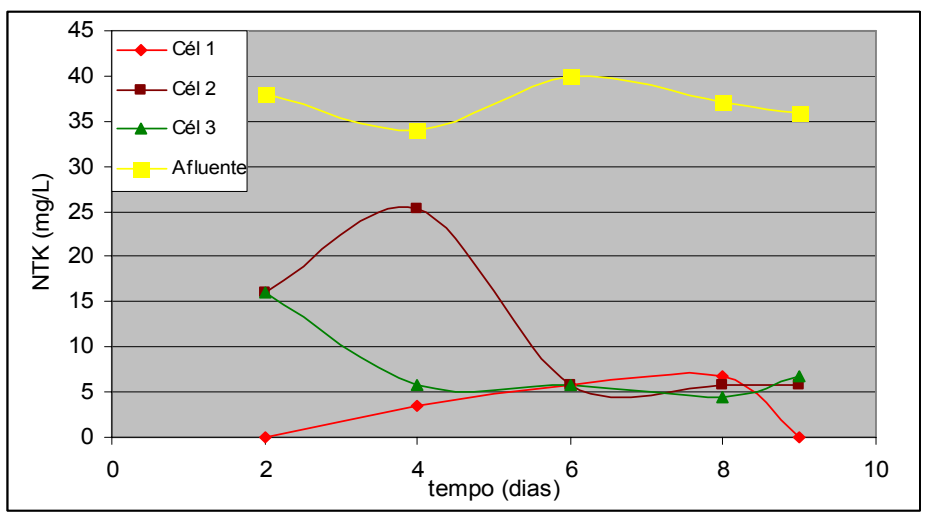

Figura 5. 51: Concentrações de NTK no afluente e nos efluentes das três células de fluxo. Taxa carreg. $=0,25 \mathrm{~g} \mathrm{~N} / \mathrm{m}^{2}{ }_{\text {biofilme.dia, Vel. } \text { superficial }}=1 \mathrm{~m} / \mathrm{h}$ (cél 1), $8 \mathrm{~m} / \mathrm{h}$ (cél 2) e $4 \mathrm{~m} / \mathrm{h}$ (cél 3), $\mathrm{T}=25 \pm 2^{\circ} \mathrm{C}$. 
Na Figura 5.49 constatou-se que houve diminuição dos valores de alcalinidade nas três células de fluxo ao longo das operações das mesmas. Verificou-se, contudo, a partir do gráfico da Figura 5.50 que não ocorreram decréscimos dos valores de $\mathrm{pH}$ dos efluentes das células como consequência do consumo da alcalinidade que se deu nas mesmas. A partir do gráfico contido na Figura 5.51, reduções dos valores de NTK puderam ser verificadas em todas as células operadas.

As concentrações dos íons nitrato e nitrito nos efluentes das três células de fluxo encontram-se nos gráficos presentes na Figura 5.52.
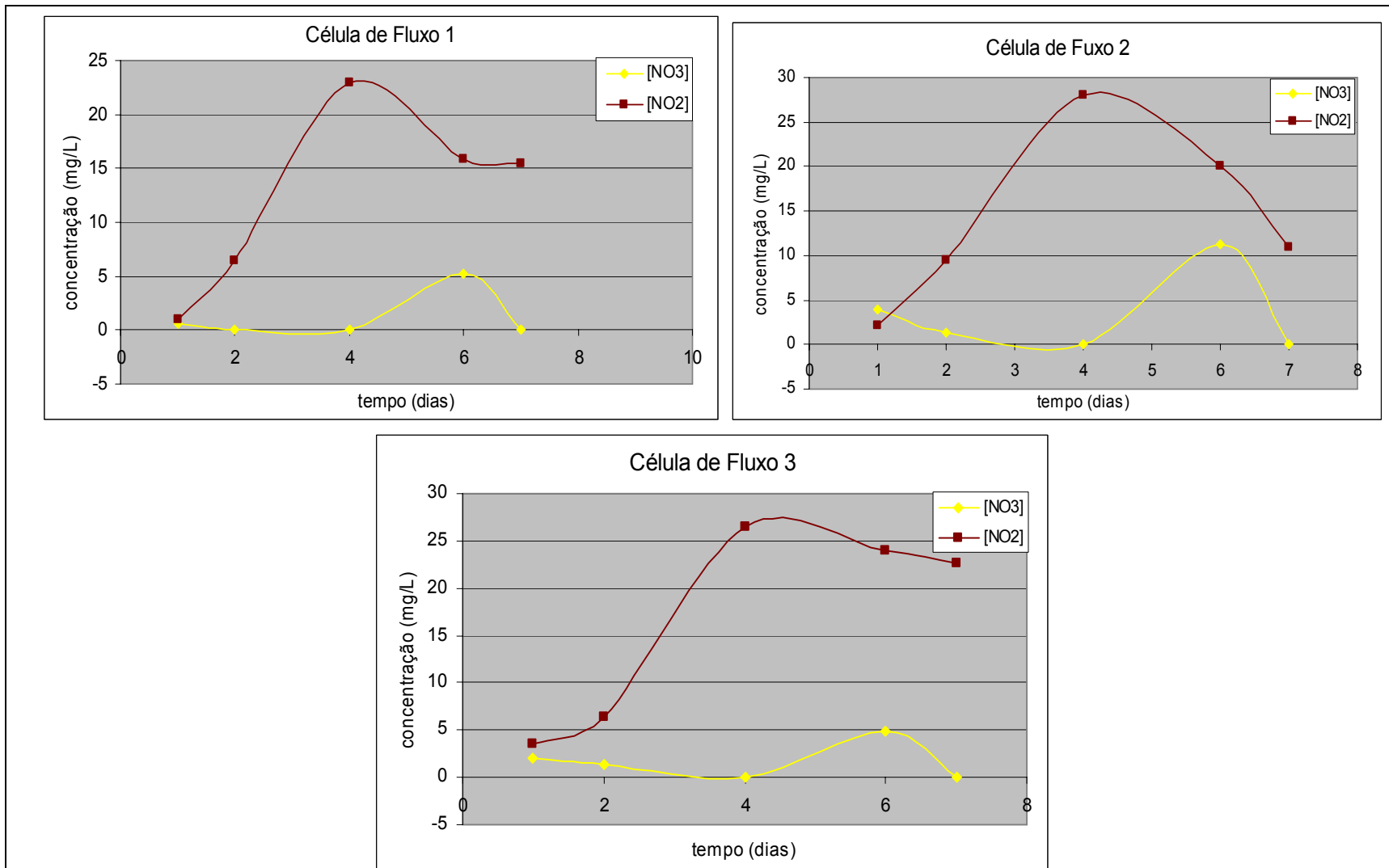

Figura 5. 52: Concentrações dos íons $\mathrm{NO}_{2}^{-}$e $\mathrm{NO}_{3}^{-}$nos efluentes das células de fluxo $1 ;$; 2 e 3 . Taxa ${ }_{\text {carreg. }}=0,25 \mathrm{~g} \mathrm{~N} / \mathrm{m}^{2}{ }_{\text {biofilme.dia, Vel. superficial }}=1 \mathrm{~m} / \mathrm{h}$ (cél 1), $8 \mathrm{~m} / \mathrm{h}$ (cél 2) e $4 \mathrm{~m} / \mathrm{h}$ (cél 3), $\mathrm{T}=25 \pm 2^{\circ} \mathrm{C}$.

Altas concentrações de íons nitrito encontravam-se presentes nos efluentes das três células de fluxo no $4^{\circ}$ dia do experimento. Foi notado, também, que as concentrações de íons nitrato presentes nos efluentes das mesmas, as quais apresentaram um pico no $6^{\circ}$ dia do ensaio, foram inferiores as dos íons nitrito durante todo o decorrer do experimento. 


\subsubsection{3- Resultados - Microssensores e análises físico-químicas}

Assim como nos experimentos anteriores, as concentrações dos íons $\mathrm{H}^{+}, \mathrm{NO}_{\mathrm{x}}{ }^{-}$e $\mathrm{NH}_{4}^{+}$ mensuradas no meio líquido das três células de fluxo obtidas por meio da aplicação dos microssensores foram comparadas com os resultados das análises físico-químicas das mesmas, com a finalidade de avaliar a eficiência dos microletrodos construídos e aplicados.

A Tabela 5.17 contém os valores de $\mathrm{pH}$ determinados nas três células de fluxo via macroeletrodo e microeletrodo de $\mathrm{pH}$.

Tabela 5. 17: Valores de pH determinados mediante o uso de macroeletrodo e de microeletrodo.

\begin{tabular}{|c|c|c|c|c|c|c|c|c|}
\hline \multicolumn{9}{|c|}{ pH } \\
\hline Cél. & $1^{\circ}$ dia & $1^{\circ} \mathrm{dia}$ & $3^{\circ}$ dia & $3^{\circ}$ dia & $5^{\circ}$ dia & $5^{\circ}$ dia & $7^{0}$ dia & $7^{\circ}$ dia \\
\hline Fluxo & Macroelet. & Microelet. & Macroelet. & Microelet. & Macroelet. & Microelet. & Macroelet. & Microelet. \\
\hline 1 & 7,3 & 7,2 & 8,0 & 8,1 & 8,0 & 7,8 & 7,7 & 7,7 \\
\hline 2 & 7,9 & 7,9 & 7,4 & 7,4 & 7,7 & 7,6 & 7,8 & 7,8 \\
\hline 3 & 7,4 & 7,5 & 8,2 & 8,3 & 7,9 & 7,9 & 7,5 & 7,6 \\
\hline
\end{tabular}

Pode ser novamente confirmado por meio da similaridade dos resultados obtidos via macro e microssensores que, os últimos apresentaram seletividade aos seus analitos $\left(\mathrm{H}^{+}\right)$.

$\mathrm{O}$ mesmo foi observado para os microssensores de íons $\mathrm{NH}_{4}{ }^{+}$, quando os resultados de NTK das análises físico-químicas foram confrontados com os valores das concentrações de íons $\mathrm{NH}_{4}^{+}$no meio líquido das três células de fluxo, conforme expostos na Tabelas 5.18:

Tabela 5. 18: Valores de concentrações de íons $\mathrm{NH}_{4}{ }^{+}$determinados mediante realização de análise físico-química (FIA) e através do uso de microssensores de íons $\mathrm{NH}_{4}^{+}$.

\begin{tabular}{|cccccccccc|}
\hline Cél. & $2^{\circ}$ dia & $2^{\circ}$ dia & $4^{0}$ dia & $4^{\circ}$ dia & $6^{\circ}$ dia & $6^{\circ}$ dia & $8^{\circ}$ dia & $8^{\circ}$ dia \\
Fluxo & FIA & Microelet. & FIA & Microelet. & FIA & Microelet. & FIA & Microelet. \\
1 & 0,0 & $4,0.10^{-3}$ & 3,4 & 3,7 & 5,7 & 5,8 & 6,8 & 8,1 \\
2 & 16,0 & 20,6 & 25,3 & 26,4 & 5,7 & 6,0 & 5,7 & 6,5 \\
3 & 16,0 & 16,5 & 5,7 & 5,6 & 5,7 & 7,2 & 4,5 & 6,1 \\
\hline
\end{tabular}

Foi notado contudo que, alguns resultados inconsistentes foram obtidos através do uso das técnicas analíticas distintas aqui discutidas, como os dados das células 1 e 2 no $2^{\circ}$ dia do experimento. A ocorrência desses desvios pode ser justificada de duas maneiras: as concentrações de íons amônio no meio liquido da célula 1 no $2^{\circ}$ dia do experimento se situaram abaixo do limite de detecção dos microeletrodos de amônio $\left(10^{-5} \mathrm{~mol} / \mathrm{L}\right.$ ou $\left.0,18 \mathrm{mg} / \mathrm{L}\right)$ e, portanto o valor da concentração dos íons amônio obtida por meio do uso desses pode ser considerada como imprecisa; microssensores com coeficiente de correlação $\left(\mathrm{R}^{2}\right)$ baixos foram utilizados para realização do microperfis de íons $\mathrm{NH}_{4}{ }^{+}$, e a credibilidade dos resultados obtidos mediante o uso desses também é reduzida. 
Mediante a realização de tais comparações foi possível concluir que os microssensores de $\mathrm{pH}$ e $\mathrm{NH}_{4}{ }^{+}$consistiram de dispositivos seletivos na mensuração de seus analitos.

\subsubsection{4- Conclusões do experimento}

Concluiu-se, deste experimento, que os microssensores empregados na mensuração das variáveis químicas ao longo das espessuras dos biofilmes formados nas superfícies das células de fluxo apresentaram bom desempenho, pois foi possível identificar diferentes concentrações de OD em determinadas zonas dos mesmos e os valores das concentrações das outras espécies químicas $\left(\mathrm{NO}_{\mathrm{x}}{ }^{-}\right.$, $\mathrm{NH}_{4}{ }^{+}$e $\mathrm{H}^{+}$) no meio líquido das três células de fluxos foram, de maneira geral, coerentes com os determinados mediante realização das análises físico-químicas.

Inferiu-se, através da observação das tendências das curvas representadas na forma de microperfis de concentrações de íons $\mathrm{NH}_{4}{ }^{+}, \mathrm{NO}_{\mathrm{x}}{ }^{-}$e $\mathrm{H}^{+}$( gradiente no sentido meio liquido - biofilme) e por meio dos resultados das análises físico-químicas dos afluentes e efluentes das três célula de fluxo operadas, que o processo de nitrificação total ocorreu no interior dos biofilmes desenvolvidos nas mesmas. Contudo, foi suposto que a nitrificação foi inibida devido à produção excessiva de nitrito, a qual foi provavelmente favorecida pelos altos valores de $\mathrm{pH}$ do meio. 


\section{6 - CONCLUSÕES E RECOMENDAÇÕES}

\section{1- CONCLUSÕES}

Em se tratando da confecção dos microssensores, incluindo as dificuldades e facilidades deparadas, concluiu-se que:

As dificuldades enfrentadas no derretimento dos vidros utilizados para confecção dos eletrodos de trabalho compostos por fios de platina $(\mathrm{Pt})$ recobertos com vidro foram superadas mediante alteração do formato da resistência aquecedora, pertencente ao equipamento empregado para derretimento dos tubos de vidro, e por meio da modificação do processo de obtenção de tais eletrodos aplicando-se menos calor nos tubos de vidro por períodos de tempo maiores. As facilidades encontradas concernentes à construção dos microssensores foram propiciadas por toda a aparelhagem e instrumenteção disponível no Laboratório de Microssensores e pela sua estrutura adequada para manipulação e manufatura dos mesmos.

Com relação aos desempenhos dos microssensores construídos no presente estudo, concluiu-se que:

Mediante a obtenção de curvas de calibração lineares com altos coeficientes de correlação $\left(\mathrm{R}^{2}\right)$, somadas aos resultados dos Testes de Seletividade, verificou-se que os microssensores potenciométricos de detecção de concentrações de íons $\mathrm{NH}_{4}{ }^{+}$e de $\mathrm{pH}$ apresentaram bom desempenho e se mostraram seletivos aos seus analitos.

Os microssensores de mensuração de íons nitrato não se revelaram seletivos aos seus íons primários $\left(\mathrm{NO}_{3}{ }^{-}\right)$e foi verificado que os mesmos detectavam íons nitrato e nitrito em amostras complexas nas quais ambos os íons se faziam presentes.

Os microssensores de determinação de concentrações de OD apresentaram estabilidade e repetibilidade em suas mensurações, tempos de resposta inferiores a $1 \mathrm{~s}$ e seletividade ao oxigênio dissolvido. Por meio do uso desses se fez possível verificar concentrações de OD distintas nas zonas internas dos biofilmes, bem como constatar as irregularidades estruturais dos biofilmes analisados.

As curvas de calibração, obtidas por meio da aplicação dos microssensores de $\mathrm{H}_{2} \mathrm{~S}$ em soluções diluídas de sulfeto de hidrogênio, indicaram que tais microssensores se mostraram sensíveis a baixas concentrações de $\mathrm{H}_{2} \mathrm{~S}$ no meio. Os altos coeficientes de correlação $\left(\mathrm{R}^{2}\right)$ dessas curvas apontaram a existência de boa correlação entre os sinais de corrente gerados pelos mesmos com as concentrações de $\mathrm{H}_{2} \mathrm{~S}$ mensuradas. 
Tratando-se agora das conclusões obtidas referentes à aplicação dos microssensores em biofilmes aderidos nas superfícies das células de fluxo, tem-se que:

Por meio dos resultados dos experimentos realizados, os reatores de bancada do tipo célula de fluxo se demonstraram adequados para o desenvolvimento de biofilmes e de seus estudos mediante aplição de microssensores.

Considerando-se ainda os experimentos realizados, concluiu-se que as condições operacionais adotadas para a célula de fluxo com taxa de carregamento de nitrogênio de $1,5 \mathrm{~g} \mathrm{~N} / \mathrm{m}^{2}$ biofilme.dia e velocidade superficial de $1 \mathrm{~m} / \mathrm{h}$ não favoreceram o desenvolvimento de biofilme nitrificante. Quando as condições de operação empregadas foram: taxa de carregamento $=0,5 \mathrm{~g} \mathrm{~N} / \mathrm{m}^{2}$ biofilme.dia e velocidade superficial $=8 \mathrm{~m} / \mathrm{h}$; para a célula de fluxo houve o crescimento de biofilme nitrificante.

No experimento em que a taxa de carregamento adotada foi de $0,5 \mathrm{~g} \mathrm{~N} / \mathrm{m}^{2}$ biofilme.dia e as velocidades superficiais aplicadas nas células $1 ; 2$ e 3 foram de $1 \mathrm{~m} / \mathrm{h}, 8 \mathrm{~m} / \mathrm{h}$ e $4 \mathrm{~m} / \mathrm{h}$, foi constatado que: a oxidação do nitrogênio amoniacal a íons nitrito e a oxidação dos íons nitrito a nitrato (menos significativa) se deram nos biofilmes aderidos nas superfícies das três células de fluxo. Quando se adotou taxa de carregamento de $1,0 \mathrm{~g} \mathrm{~N} / \mathrm{m}^{2}$ biofilme.dia para as três células de fluxo $(1 ; 2$ e 3$)$, e empregou-se para as mesmas velocidades superficiais de $1 \mathrm{~m} / \mathrm{h}, 8 \mathrm{~m} / \mathrm{h}$ e $4 \mathrm{~m} / \mathrm{h}$, a nitrificação total não foi promovida no interior dos biofilmes desenvolvidos e a nitrificação via curta foi pouco expressiva nas células de fluxo 1 e 2 . Por fim, no experimento em que a taxa de carregamento adotada foi de $0,25 \mathrm{~g}$ $\mathrm{N} / \mathrm{m}^{2}$ biofilme.dia e as velocidades superficiais aplicadas nas células $1 ; 2$ e 3 foram mantidas em $1 \mathrm{~m} / \mathrm{h}, 8$ $\mathrm{m} / \mathrm{h}$ e $4 \mathrm{~m} / \mathrm{h}$, o processo de nitrificação praticamente total ocorreu nas zonas internas dos biofilmes desenvolvidos nas três células de fluxo operadas e que, contudo a nitrificação foi inibida devido à produção excessiva de íons nitrito.

Conclui-se, portanto que, os microssensores construídos na presente pesquisa (com exceção do microssensor de $\mathrm{H}_{2} \mathrm{~S}$ ) foram aplicados com sucesso em biofilmes empregados na nitrificação de água residuária, possibilitando a verificação da ocorrência de processos biológicos no interior das espessuras dos mesmos.

\section{2- RECOMENDAÇÕES}

Para que o acompanhamento do desenvolvimento de biofilmes mediante a aplicação de microssensores seja feito de forma mais efetiva, a fixação do servo motor (o qual rege os micropassos dos microssensores ao longo das espessuras do biofilme) em local único e inalterável acima da célula de fluxo, na qual o biofilme encontra-se aderido, consiste em alternativa interessante. Assim sendo, os 
microperfis de concentrações de variáveis distintas no interior de biofilmes seriam todos obtidos exatamente no mesmo local da célula de fluxo.

Outra proposta importante concernente a análise de biofilmes por meio do uso de microssensores consiste na aquisição de sistema tridimensional o qual permitiria a obtenção de microperfis tridimensionais de substratos diversos no interior de biofilmes.

A utilização de geradores coulométricos de soluções de $\mathrm{H}_{2} \mathrm{~S}$ consiste em proposta atraente para calibração dos microssensores de $\mathrm{H}_{2} \mathrm{~S}$, já que essa é muito dificultada pela elevada oxidação e volatilidade do gás. Geradores desse tipo, nos quais soluções de concentrações desejadas de $\mathrm{H}_{2} \mathrm{~S}$ são obtidas por meio de redução catódica que ocorre na superfície de eletrodo de $\mathrm{HgS}$ (componente do gerador), foram utilizados para o mesmo fim que aqui está sendo considerado por Jeroschewski et al., 1996, Jeroschewski et al., 1998, Spilker et al., 2008 , entre outros. 


\section{7-REFERÊNCIAS BIBLIOGRÁFICAS}

ALLDREDGE, A.L.; COHEN, Y. (1987). Can microscale chemical patches persist in the sea?

Microelectrode study of marine snow, fecal pellets. Science, v.235, p.689.

AMMANN, D.; LANTER, F.; STEINER, R.A.; SCHULTHESS, P. (1981). Neutral carrier based hydrogen ion selective microelectrode for extra- and intracellular studies. Anal.Chem., v.53, p.2267.

AMMANN, D. (1986). Ion-Selective Microelectrodes Principles, Design and Application Springer, New York.

ANDREWS, G.F.; TRAPASSO, R. (1985). The Optimal Design of Fluidized Bed Bioreactors. J. Water Pollution Control Federation, v.57, p.143-150.

APHA - American Public Health Association (2001) Compendium of methods for the microbiological examination of foods. 4. ed. Washington,DC.

ARAÚJO J. C. (2001). Biofilmes anaeróbios: desenvolvimento e caracterização filogenética usando a hibridação in situ com sondas fluorescentes. 28p. Tese (Doutorado) - Escola de Engenharia de São Carlos, Universidade de São Paulo, São Carlos, 2001.

ARCHER, D.; EMERSON, S.; REIMERS, C.E. (1989). Dissolution of calcite in deep-sea sediments: pH and $\mathrm{O}_{2}$ microelectrodes results. Geochim. Cosmohim. Acta, v.53, p.2831.

ATKINSON, J.K; CRANNY, A.W.J.; GLASSPOOL, W.V.; MIHELL, A. (1999). An investigation of the performance characteristics and operational lifetimes of multielement thick film sensor arrays used in determination of water quality parameters. Sensors and Actuators B, v.54, p.215- 231.

BAE, W.; BAEK, S.; CHUNG, J.; LEE, Y. (2002). Optimal operational factors for nitrite accumulation in bath reactors. Biodegradation, v.12, p.359-366.

BAUMGARTL, H.; LUBBERS, D.W. (1973). Platinum needle electrodes for polarographic measurement of oxygen and hydrogen. Oxygen Supply, p.130.

BECKMAN, A. O. (1987). Hexagon. v. 78, p. 41.

BERNER, R.A. (1963). Electrode studies of hydrogen sulfide in marine sediments. Geochim. Cosmochim. Acta, v.27, p.563-575.

BERTOTTI, M.; LOWINSOHN, D. (2006). Sensores Eletroquímicos: Considerações sobre mecanismos de funcionamento e aplicações no monitoramento de espécies químicas em ambientes microscópicos. Química Nova, São Paulo, v.29, n.6, p.1318-1325. 
BETTIN, S.M.; TEIXEIRA, J.P.; SANTOS, C.B. (2006). Pilha de Daniel. Disponível em http://educar.sc.usp.br/licenciatura/2006/Pilha_de_Daniel/pilha_de_Daniell.html.

BEYENAL, H.; LEWANDOWSKI, Z. (2000). Concentration and Flow Velocities at witch Biofilms were Grow on Effective Diffusivity. Water Research, v.34, p.528-538.

BOLLMANN, A.; REVSBECH, N.P. (2005). An $\mathrm{NH}_{4}{ }^{+}$biosensor based on ammonia-oxidizing bacteria for use under anoxic conditions. Sensors and ActuatorsB-chemical, v. 105, n.2, p.412-418.

BRETT, C.M.A.; BRETT, A.M.O. (1993). Electrochemistry: principles, methods, and applications. 1ed. New York, USA.

BRYERS, J.D. (1988). Modeling Biofilm Accumulation. In: Bazin, J.B.\&Drossen, J.F. Physiological Models in Microbiology, v.II, cap.11, p.109-144.

BROWN, F.O.; LOWRY, J.P. (2003). Microelectrochemical sensor of in vivo brain analysis: an investigation of procedures for modifying Pt electrodes using Nafion (R).Analyst, v.128, p.700-705. BUHLMANN, P.; BAKKER, E.; PRETSCH, E. (1999) Polymer Membrane Ion- Selective Electrodes What are the limits?. Electroanalysis, v.11, n.13, p.915-933.

BUHLMANN, P.; YAJIMA, S.; TOHDA, K.; UMEZAWA, Y. (1995).EMF response of neutral-carrier based ion-sensitive field-effect transistors with membranes free of ionic sites. Eletrochem. Acta, v.40, p.3021-3027.

BUHLMANN, P.; PRESTSCH, E.; BAKKER, E. (1998). Carrier- based ion-selective electrodes and bulk optodes. 2. Ionophores for potentiometric and optical sensors. Chem Rev., v.98, p.15931687.

BUNGAY, H.R. (1969). Microprobe technique for determining diffusivities and respiration rates in microbial slime systems. Biotech. Bioeng., v.11, p.765.

CAI, W.J.; REIMERS, C.E. (2000). Sensors for in situ $\mathrm{pH}$ and $\mathrm{pCO}_{2}-$ Measurements in Seawater and at sediments- Water Interface. BUFFLE, J.; LEEUWEN, H.P. (2000). In situ Monitoring of Aquatic Systems - Chemical Analysis and Speciation. Switzerland: Geneva. Cap 3, p.95-99.

CHARACKLIS, W.G.; MARSHALL, K.C. (1990). Biofilms: A basis for an interdisciplinary approach. Biofilm, New York, p.3-15.

CAMPOS, J.R. (1989). Remoção de DQO e de Nitrogênio em um Sistema de Três Reatores Biológicos de Filme Fixo em Série. 96p. Tese (Livre Docência) - Escola de Engenharia de São Carlos, Universidade de São Paulo, São Carlos, 1989.

COSTERTON, J.W.; LEWANDOWSKI, Z.; CALDWELL, D.E.; KOBBER, D.R.; LAPPINSCOOT, H.M. (1995). Microbial Biofilms. Annuary Review of Microbiology, v.49, p.711-745. 
DE BEER, D.; VEN DEN HEUVEL, J.C.; OTTENGRAF, S.P.P. (1993). Microelectrode measurements of the activity distribution in nitrifying bacterial aggregates. Applied and Environmental Microbiology, v.59, p.1131-1138.

DE BEER, D.; SCHRAMM, A.; SANTEGOEDS, C.M.; KU“HL, M. (1997). A Nitrite Microsensor for Profiling Environmental Biofilms. Applied and Environmental Microbiology. 63 (3): 973-977.

EBERL, H.J.; PICIOREANU, C.; HEIJNEN, J.J.; VAN LOOSDRECHT, M.C.M. (2000). A threedimensional numerical study on the correlation of spatial structure, hydrodinamic conditions, and mass transfer and conversion in biofilms. Chem. Eng. Sci., v.55, p.6209-6222.

FAWCETT, W.R.; KLOSS, A.; CALVENTE, J.J.; MARINKOVIC, N. (1998). SNIFTIRS studies of the electrical double layer at gold electrodes .Electrochim. Acta, v.44, n.6-7, p.881-887.

FERREIRA, M.A.C. (2007). Desenvolvimento de sensores de oxigênio dissolvido utilizando métodos eletroquímicos e ópticos para monitoramento em tempo real da qualidade da água. 25p. Tese (Doutorado) - Escola Politécnica da Universidade de São Paulo, Universidade de São Paulo, São Paulo, 2007.

FILHO, J.L.R.P. (2008). Avaliação da utilização de diferentes materiais suporte na biofiltração de sulfeto de hidrogênio. 13p. Dissertação (Mestrado) - Escola de Engenharia de São Carlos, Universidade de São Paulo, São Carlos, 2008.

FLETCHER, M. (1987). How do bacteria attach to solid surfaces? Microbiol. Sci.,v.4, p.133-136.

FUNGARO, D.A.; BRETT, C.M.A. (2000). Eletrodos Modificados com polímeros perfluorados e sulfonados: aplicações em análises ambientais. Química Nova, v.23, p.805.

GEBARA, D.; SOBRINHO, M.D.A.; JÚNIOR, H.C.R. (2006). Determinação da espessura e massa específica do biofilme em reatores de leito fluidizado. In: VIII Simpósio Ítalo Brasileiro de Engenharia Sanitária e Ambiental, II 076, 2006. Ilha Solteira. p. 1-7.

GUIOT, S.R.; PAUSS, A.; COSTERTON, J.W. (1992). A Structured Model of the Anaerobic Granule Consortium. Water Science and Technology, v.25, p.1-10.

GLUD, R.N.; GUNDERSEN, J.K.; RAMSING, N.B. (2000). Electrochemical and Optical Oxygen Microsensors for in situ measurements. BUFFLE, J.; LEEUWEN, H.P. (2000). In situ Monitoring of Aquatic Systems - Chemical Analysis and Speciation. Switzerland: Geneva. Cap 2, p.23-28.

GODINHO, M.I.C.C. (2005). Análise Instrumental II - Parte Teórica. Instituto Superior de Engenharia de Lisboa. Technical Report Fpl- Gtr- 7. 
HANGEDORN-OLSEN, C.; MULLER, I.H.; TUTTRUP, H.; HARREMOES, P. (1994). Oxygen reduces denitrification in biofilm reactors. Water Science and Technology, v.29, n.10-11, p.8391.

HIRATA, Y.; MIZUTANI, F.; YOKOYAMA, H. (1999).In situ observations of electrodes surfaces using scanning Maxwell-stress microscopy (SMM). Surf. Interf. Anal., v.27, n.5-6, p.317-323.

HITCHMAN, M.L. (1983). Measurement of dissolved oxygen sensors. Spring Verlag, New York, p.18-30.

HU, X.; LENG, Z. (1996). Determination of trace-levels of sulfide by high sensitive potentiometry with a carbon paste electrode. Anal. Commun., v.33, p.297-298.

INTERNATIONAL UNION OF PURE AND APLLIED CHEMISTRY (1973). Recommendations for nomenclature of ion-selective electrodes. Oxford, New York, Paris, Frankfurt.

JANATA, J. (1994). 20 Years of ion selective field-effect transistors. Analyst,v.119, n.11, p.22752278.

JACKSON, G.; HALUK, B.; REES, W.M.; LEWANDOWSKI, Z. (2001) Growing reproducible biofilms with respect to structure and viable cell counts. Journal of Microbiological Methods, v. 47, p.1-10.

JEROSCHEWSKI, P.; HAASE, P.; TROMMER, A.; GRUNDLER, P. (1993). Galvanic sensor for the determination of hydrogen sulphide / sulphide in aqueous media. Fresenius'J. Anal.Chem., v.346, p.930-933.

JEROSCHEWSKI, P.; STEUCKART, C.; KUHL, M. (1996). An amperometric microsensor for the determination of $\mathrm{H}_{2} \mathrm{~S}$ in aquatic environments. Anal. Chem., v.68, p.4351-4357.

JEROSCHEWSKI, P.; EICKERT, G.; STEUCKART,C.; KUHL, M. (1998). A $\mathrm{H}_{2} \mathrm{~S}$ microsensor for profiling biofilms and sediments: application in an acidic lake sediment.

JORGENSEN, B.B., EREZ, J.; REVSBECH, N.P.; COHEN, Y. (1985). Symbiotic photosynthesis in a planktonic foraminiferan, studies with microelectrodes. Limnol. Oceanogr., v.30, p.1253.

JORGENSEN, B.B.; REVSBECH, N.P. (1986). Microelectrodes: their use in microbial ecology Adv. Microb.Ecol., v. 9, p. 293-352.

JORGENSEN, B.B., REVSBECH, N.P. (1988). Microsensors. Meth. Enzymol., v.167, p. 639-659.

KREFT, J-U.; WIMPENNY, J.W.T. (1998). Bac Sim, a simulator for individual-based modeling of bacterial colony growth. Microbiology, v.144, p.3275-3287. 
KREFT, J-U.; WIMPENNY, J.W.T. (2001). Effect of EPS on biofilm structure and function as revealed by an individual-based model of biofilm growth. Water Science and Technology, v.43, p.135141.

KUBOTA, L.T.; FERNANDES, J.C.B.F.; NETO, G.O. (2001). Eletrodos íon-seletivos: histórico, mecanismo de resposta, seletividade e revisão dos conceitos. Química Nova, Campinas, v.24, n.1, p.120-130.

KUHL, M.; STEUCKART, C.; EICKERT, G.; JEROSCHEWSKI, P. (1998). A $\mathrm{H}_{2} \mathrm{~S}$ for porfiling biofilms and sediments: application in an acidic lake sediment. Aquatic Microbial Ecology, v.15, p.201-209.

KUHL, M.; STEUCKART, C. (2000). Sensors for in situ analysis of sulfide in aquatic systems. In situ Monitoring of Aquatic Systems - Chemical Analysis and Speciation. Switzerland: Geneva. Cap 4, p.145-149.

KUROSAWA, H.; HIRANO, H.; NAKAMURA, K.; AMANO, Y. (1994). Microbial sensor for selective determination of sulphide. Appl. Environ. Microbiol., v.41, p.556-559.

LAMON, A.W.; SARTI, A.; GONZALEZ, B.C.; CAMPOS, J.R. (2008). Sistema Avançado para Avaliação de Crescimento de Biofilme Aeróbio/Anaeróbio por Meio de Microssensores. In: XXXI CONGRESSO INTERAMERICANO AIDIS. Santiago - Chile.

LAMON, A.W.; CAMPOS, J.R.; SILVEIRA, P.E.; SIMAN, R.R. (2007). Confecção, Avaliação e Aplicação de Microssensores de Oxigênio Dissolvido para Estudos de Biofilmes. In: $24^{\circ}$ CONGRESSO BRASILEIRO DE ENGENHARIA SANITÁRIA, Belo Horizonte - MG.

LARSEN, L.H.; REVSBECH, N.P.; BINNERUP, S.J. (1996). A microsensor for nitrate based on immobilized denitrifying bacteria. Appl. Environ. Microbiol., v.62, p.1248-1251.

LEWANDOWSKI, Z.; WALSER, G.; CHARACKLIS, W.G. (1991). Reaction Kinectis in Biofilms. Biotechnology and Bioengineering, v.38, p.877-882.

LEWANDOWSKI, Z.; DE BEER, D.; STOODLEY, P.; ROE, F. (1995). Effects of Biofilm Structures on Oxygen Distribution and Mass Transport. Biotechnology and Bioengineering, v.43, p.11311138.

LEWANDOWSKI, Z.; BEYENAL, H. (2003). Use of microsensors to study biofilms. LENS, S.; MORAN, A.P.; MAHONY, T.; STOODLEY, P.; O'FLAHERTY, V. Biofilms in Medicine, Industry and Environmental Biotechnology: Characteristics, Analysis and Control. LondonUK, Cap.21, p.374-411. 
LEWANDOWSKI, Z.; BEYENAL, H. (2006). Introduction to Biofilms and to Biofilm Research.In: Fundamentals of Biofilm Research. Cap 1, p.8-13.

LU, R.; YU, T. (2002). Fabrication and evaluation of an oxygen microelectrode applicable to environmental engineering and science. J. Envriron. Eng. Sci., v.1, p.225-235.

MA; Y.L.; ZHAO, J.L.; YANG, B.L. (2006). Removal of $\mathrm{H}_{2} \mathrm{~S}$ in waste gases by an active carbon bioreactor. International Biodeterioration \& Biodegradation, v.57, p.93-98.

MARSHALL, K.C. (1986). Adsorption and adhesion process in microbial growth at interfaces. Adv. Colloid Interface Sci., v.25, p.50-86.

MOODY, G.J.; OKE, R.B.; THOMAS, J.D.R. (1970). Calcium-sensitive electrode based on a liquid ion exchanger in a poly (vinil-chloride) matrix. Analyst, v.95, n.1136, p.910.

MURRAY, R.W. (1980). Chemiccaly modified electrodes. Acc. Chem. Rev., v.13, n.5, p.135-141.

NATAN, M.J.; WRIGHTON, M.S. (1990). Progress in inorganic chemistry. Wiley- Interscience, New York, v.37, p.391-494.

NEDOVIC, V.; WILLAERT, R. (2005). Applications of Cell Immobilization Biotechnology. Springer, p.566.

OLIVEIRA, A.L. (2003). Desnitrificação em sistemade reatores sequenciaisem batelada tratandoesgoto sanitário sintético usando como fonte de carbonoo próprio esgoto sintético. In: $22^{0}$ CONGRESSO BRASILEIRO DE ENGENHARIA SANITÁRIA, Joinville - SC.

PICIOREANU, C.; VAN LOOSDRECHT, M.C.M.; HEIJNEN, J.J. (1998) Mathematical modeling of biofilm structure with a hybrid differential-discrete cellular automaton approach. Biotechnol.Bioeng.,v.58, p.101-116.

PICIOREANU, C.; VAN LOOSDRECHT, M.C.M.; HEIJNEN, J.J. (2000). A theoretical study on the effect of surface roughness on mass transport and transformation in biofilms. Biotechnol.Bioeng., v.68, p.355-369.

PICIOREANU, C.; VAN LOOSDRECHT, M.C.M.; HEIJNEN, J.J. (2001).Two-dimensional model of biofilm detachment caused by internal stress from liquid flow. Biotechnol.Bioeng., v.72, p.205218.

PIZARRO, G.; GRIFFEATH, D.; NOGUERA. D.R. (2001). Quantitative cellular automation model for biofilms. J. Environ.Eng., v.127, p.782-789.

POLANCO, F; VILLAVERDE, S.; GARCIA, P.A. (1996). Nitrite accumulation in submerged biofilters - combined effects. Water Science and Technology, v.34, n.3-4, p.371-378. 
PUCACCO, L.R.; CORONA, S.K.; JACOBSON, H.R.; CARTER, N.W. (1986). pH microelectrode: modified recessed tip configuration. Anal. Chem., v.153, p.251-261.

PUNGOR, E.; TOTH, K. (1970). Ion- selective membrane electrodes. A Review. Analyst., v.95, p.625.

REVSBECH, N.P.; JORGENSEN, B.B.; BLACHBURN, T.H. (1983). Microelectrode studies of the photosynthesis and $\mathrm{O}_{2}, \mathrm{H}_{2} \mathrm{~S}$, and $\mathrm{pH}$ profiles of a microbial mat. Limnol. Oceanogr., v.28, p.10621074.

REVSBECH, N.P.; (1989). An oxygen microsensor with a guard cathode. Limnol. Oceanogr., v.34, p.474-478.

REVSBECH, N.P. (1994). Analysis of microbial mats by use of electrochemical microsensors: recent advances. Microbial Mats, p.135.

RITTMANN, B.E.; MANEM, J.A. (1992). Development and experimental evaluation of a steady-state, multispecies biofilm model. Biotechnol., v.39, p.914-922.

ROSS, J.W.; (1967). Calcium - selective electrode with liquid ion exchanger. Science, v.156, n.3780, p.1378.

RUZICKA, J. (1997). The seventies- Golden age for ion selective electrodes. J. Chem. Educ, v. 74, n.2, p. 167-170.

SKOOG, D.A.; HOLLER, F.J.; NIEMAN, T.A. (2002). Princípios de Análise Instrumental. 5.ed, Porto Alegre/ São Paulo.

SKOOG, D. A.; HOLLER, F.J.; NIEMAN, T.A. (2006). Fundamentos de química analítica. Tradução de Marco Tadeu Grassi. São Paulo.

SIMAN, R.R. (2007). Reator de Leito Expandido em Escala Plena com Zonas Anaeróbia e Aeróbia sobrepostas: Remoção conjunta de Matéria Orgânica e Nutrientes e Estudo do Comportamento Microbiológico do Biofilme, por Respirometria e Microsensor de OD.17p. Tese (Doutorado) - Escola de Engenharia de São Carlos, Universidade de São Paulo, São Carlos, 2007.

SPILKER, B.; RANDHAHN, J.; GRABOW, H.; BEIKIRCH, H.; JEROSCHEWSKI, P. ( 2008). New electrochemical sensor for the detection of hydrogen sulfide and other redox active species. $\mathbf{J}$. Electroanalytical Chemistry, v.612, p.121-130.

SPÍNOLA, A.L.G. (2009). Desenvolvimento de biofilmes aeróbios para remoção de nitrogênio em células de fluxo, submetidos a diferentes velocidades superficiais e taxas de carregamento. Dissertação (Mestrado) - Escola de Engenharia de São Carlos, Universidade de São Paulo, São Carlos, 2009. 
STOODLEY, P.; DIRKX, P. (2003). Structure-Function Collection. Montana State University, College of Engineering, Center for Biofilm Engineering. Disponível em http://www.erc.montana.edu/ResLib99-SW/Image_Library.

THOMAS, R.C. (1978). Íons Selective Intracellular Microelectrodes, How to make and Use Them, Academic Press, London.

TRIQUES, M.R.M. (1996). Estudo sobre aplicação de ultramicroeletrodos para determinação de oxigênio dissolvido em água. 117p. Tese (Doutorado) - Instituto de Química de São Carlos, Universidade de São Paulo, São Carlos, 1996.

TSE, Y.; JANDA, P.; LEVER, A.B.P. (1994). Electrode with electrochemically deposited $\mathrm{N}, \mathrm{N}, \mathrm{N}$ ', $N$ ',"'-Tetramethyltetra-3,4-pyridinoporphyrazinocobalt (I) for detection of sulfide ion. Anal. Chem., v.66, p.384-390.

UMEZAWA, Y.;UMEZAWA K.; SATO, H. (1995). Selectivity coefficients for ion-selective electrodes; Recommended methods for reporting $K_{\text {pot }}$ values. Pure and Appl. Chem., v.57, n.3, p.507-518.

VAN HOUDT, P.; Lewandowski, Z. and Little, B. (1992). Iridium oxide pH microelectrode. Biotechnol. Bioeng., v.40, p. 601-608.

VIEIRA, L.G.T. (2000). Desenvolvimento de sistema misto (aeróbio-anaeróbio) de leito fixo para remoção de nitrogênio de esgoto sanitário pré-tratado em reator anaeróbio. $144 \mathrm{p}$. Tese (Doutorado) - Escola de Engenharia de São Carlos, Universidade de São Paulo, São Carlos, 2000.

VON SPERLING, M. (1997). Princípios do tratamento biológico de águas residuárias. v.4. Lodos Ativados. Departamento de engenharia sanitária e ambiental- UFMG.

XAVIER, J.B.; PICIOREANO, C.; ALMEIDA, J.S; VAN LOOSDRECHT, C.M. (2002). Monitorização e modelação da estrutura de biofilmes. Boletim de Biotecnologia, p.1-10.

WANNER, O.; GUJER, W. (1986). A multispecies biofilm model. Biotechenol. Bioeng., v.28, p.314328.

WHALEN, W.J.; RILEY, J.; NAIR, P. (1967). A microelectrode for measuring intracellular $\mathrm{pO}_{2}$. J. Appl. Physiol., v.23, p.798.

WIMPENNY, J.W.T.; COLASANTI, R.A. (1997). A unifying hypothesis for the structure of microbial biofilms based on cellular automaton models. FEMS Microbiol. Ecol., v.22, p.1-16.

WU, W.; HU, J.; GU, X.; ZHAO, Y.; ZHANG, H.; GU, G. (1987). Cultivation of Aerobic Cultivated Sludge as Seed. Water Research, v.21, n.7, p.789-799. 
YAJIMA, S.; TOHDA, K.; BUHLMANN, P.; UMEZAWA, Y. (1997). Donnan exclusion failure of neutral ionophore-based ion-selective electrodes studied by optical second - harmonic generation. Anal. Chem. Acta, v.69, n.10, p.1919-1924.

YOO, H.; AHN, K.; LEE, K.; KWAK, Y.; SONG, K. (1999). Nitrogen Removal from synthetic wastewater by simultaneous nitrification and denitrification (SND) via nitrite in an intermittentlyaerated reactor. Water Resource, v.33, n.1, p.145-154. 